University of Tennessee Health Science Center UTHSC Digital Commons

\title{
Therapeutic Effects of Ormeloxifene in Cervical Cancer Carcinogenesis
}

Neeraj Chauhan

University of Tennessee Health Science Center

Follow this and additional works at: https://dc.uthsc.edu/dissertations

Part of the Medical Cell Biology Commons, Neoplasms Commons, and the Oncology Commons

\section{Recommended Citation}

Chauhan, Neeraj (http://orcid.org/0000-0002-9252-9897), "Therapeutic Effects of Ormeloxifene in Cervical Cancer Carcinogenesis" (2017). Theses and Dissertations (ETD). Paper 431. http://dx.doi.org/10.21007/ etd.cghs.2017.0439.

This Dissertation is brought to you for free and open access by the College of Graduate Health Sciences at UTHSC Digital Commons. It has been accepted for inclusion in Theses and Dissertations (ETD) by an authorized administrator of UTHSC Digital Commons. For more information, please contact jwelch30@uthsc.edu. 


\title{
Therapeutic Effects of Ormeloxifene in Cervical Cancer Carcinogenesis
}

\begin{abstract}
Cervical cancer $(\mathrm{CxCa})$ remains the fourth leading cause of cancer related deaths among women worldwide. Cervical cancer is mainly ( 99.7\%) derived from high risk Human papillomavirus (HR HPV). HPV E6/E7 are the two main oncoproteins that interfere with p53 and pRb (retinoblastoma) cell cycle regulatory proteins and hinder their efficacy of controlling cell growth. Additionally, PI3K-Akt is a cell survival pathway that is aberrantly expressed in cervical cancer cells. This pathway has a profound role in inhibiting mitochondrial intrinsic apoptotic signaling pathway. Advanced stage cervical cancer is difficult to treat and patients diagnosed with metastatic disease have a poor survival rate. Therefore, there is an urgent need to develop newer treatment modalities. Ormeloxifene (ORM) is a non-hormonal, antiestrogen, oral contraceptive for human use. Growing evidences also suggest that ormeloxifene has anticancerous properties in a variety of cancers. Developing nanoformulation of drugs has received much attention lately as nanoparticles have site specific targeted drug delivery. Nanoparticles have a specific size range that makes them capable of being entrapped and accumulated at the tumor site due to its leaky vasculature. As a result of it, drug is released from the particle core at a sustained rate; therefore, nanoparticulates offer enhanced bioavailability and better therapeutic efficacy. Considering these benefits, we engineered ormeloxifene loaded PLGA based novel nanoformulation (PLGA-ORM). In this work we validated anti-cancer properties of free ORM and its PLGA based nanoformulation. Our set of data showed that ormeloxifene significantly decreased the cellular proliferation and clonogenic potential of cervical cancer cells. Ormeloxifene also reduced the cellular motility and induced the apoptosis via targeting PI3K-Akt signaling in these cells. Furthermore, ormeloxifene modulated the HPV induced oncogenesis in Caski cells. Ormeloxifene also showed additive inhibitory effects on cellular proliferation and growth when used with radiation. Moreover, our novel PLGA-ORM had a particle size range of $100-$ $280 \mathrm{~nm}$ and also exhibited excellent encapsulation of ormeloxifene in to PLGA core. PLGA-ORM was labeled with Coumarin 6 (green fluorescent) dye for its uptake studies, where PLGA-ORM internalized in cervical cancer cells in dose, time and energy dependent manner via endocytosis pathway. PLGA-ORM showed improved anti-proliferative/growth properties than free ormeloxifene in cervical cancer cells. When utilized in animals (an orthotopic mouse model) both ormeloxifene and PLGA-ORM showed great anti-tumorous properties, however PLGA-ORM had improved inhibitory effects on tumor growth than free ormeloxifene. To conclude, ormeloxifene and its nanoformulation have the potential to be a novel treatment modality for cervical cancer which can reduce the overall disease burden and improve patients' life expectancy.
\end{abstract}

\section{Document Type}

Dissertation

Degree Name

Doctor of Philosophy (PhD)

Program

Pharmaceutical Sciences

Research Advisor

Subhash C. Chauhan, Ph.D.

Keywords

Cervical Cancer, Ormeloxifene, PI3K-Akt, PLGA-ORM 


\section{Subject Categories}

Medical Cell Biology | Medical Sciences | Medical Specialties | Medicine and Health Sciences | Neoplasms I Oncology

\section{Comments}

Embargo expires May 2020. 
Therapeutic Effects of Ormeloxifene in Cervical Cancer Carcinogenesis

\author{
A Dissertation \\ Presented for \\ The Graduate Studies Council \\ The University of Tennessee \\ Health Science Center \\ In Partial Fulfillment \\ Of the Requirements for the Degree \\ Doctor of Philosophy \\ From The University of Tennessee
}

By

Neeraj Chauhan

May 2017 
Portions of Chapters 1, 7 and 10 (C) 2015 by Science Direct. All other material (C) 2017 by Neeraj Chauhan. All rights reserved. 


\section{DEDICATION}

I dedicate this dissertation to my loving mother who couldn't see this work completed, late Mrs. Rama Chauhan. She was the person who always stood for me with her unconditional love, support and continuous encouragement to succeed. 


\section{ACKNOWLEDGEMENTS}

I would like to thank everyone who supported me towards the completion of this dissertation throughout my academic period here at University of Tennessee Health Science Center. I express my sincere gratitude to my mentor Dr. Subhash C. Chauhan. I am truly thankful and grateful to him for providing me his constant support, opportunities and motivation to conduct my doctoral research in his laboratory. Dr. Chauhan has been a wonderful person and an amazing guide throughout this period.

I would also like to express my sincere thanks to my dissertation committee members, Dr. Stephen W. Behrman, Dr. Vivian S. Loveless, Dr. Yi Lu, and Dr. Murali M. Yallapu for their valuable suggestions and directions for the successful completion of this dissertation project.

I also want to convey my sincere thanks to the dean of the graduate school, Dr. Donald B. Thomason for his continuous support and encouragement.

Finally, I would like to thank my parents Mr. Anand Chauhan and late Mrs. Rama Chauhan for their valuable support, love and care. Also, I want to thank my role model, my late grandfather Mr. Jaswant Singh. 


\begin{abstract}
Cervical cancer $(\mathrm{CxCa})$ remains the fourth leading cause of cancer related deaths among women worldwide. Cervical cancer is mainly $(\sim 99.7 \%)$ derived from high risk Human papillomavirus (HR HPV). HPV E6/E7 are the two main oncoproteins that interfere with $\mathrm{p} 53$ and $\mathrm{pRb}$ (retinoblastoma) cell cycle regulatory proteins and hinder their efficacy of controlling cell growth. Additionally, PI3K-Akt is a cell survival pathway that is aberrantly expressed in cervical cancer cells. This pathway has a profound role in inhibiting mitochondrial intrinsic apoptotic signaling pathway. Advanced stage cervical cancer is difficult to treat and patients diagnosed with metastatic disease have a poor survival rate. Therefore, there is an urgent need to develop newer treatment modalities. Ormeloxifene (ORM) is a non-hormonal, anti-estrogen, oral contraceptive for human use. Growing evidences also suggest that ormeloxifene has anticancerous properties in a variety of cancers. Developing nanoformulation of drugs has received much attention lately as nanoparticles have site specific targeted drug delivery. Nanoparticles have a specific size range that makes them capable of being entrapped and accumulated at the tumor site due to its leaky vasculature. As a result of it, drug is released from the particle core at a sustained rate; therefore, nanoparticulates offer enhanced bioavailability and better therapeutic efficacy. Considering these benefits, we engineered ormeloxifene loaded PLGA based novel nanoformulation (PLGA-ORM). In this work we validated anti-cancer properties of free ORM and its PLGA based nanoformulation. Our set of data showed that ormeloxifene significantly decreased the cellular proliferation and clonogenic potential of cervical cancer cells. Ormeloxifene also reduced the cellular motility and induced the apoptosis via targeting PI3K-Akt signaling in these cells. Furthermore, ormeloxifene modulated the HPV induced oncogenesis in Caski cells. Ormeloxifene also showed additive inhibitory effects on cellular proliferation and growth when used with radiation. Moreover, our novel PLGA-ORM had a particle size range of $100-280 \mathrm{~nm}$ and also exhibited excellent encapsulation of ormeloxifene in to PLGA core. PLGA-ORM was labeled with Coumarin 6 (green fluorescent) dye for its uptake studies, where PLGA-ORM internalized in cervical cancer cells in dose, time and energy dependent manner via endocytosis pathway. PLGA-ORM showed improved antiproliferative/growth properties than free ormeloxifene in cervical cancer cells. When utilized in animals (an orthotopic mouse model) both ormeloxifene and PLGA-ORM showed great anti-tumorous properties, however PLGA-ORM had improved inhibitory effects on tumor growth than free ormeloxifene. To conclude, ormeloxifene and its nanoformulation have the potential to be a novel treatment modality for cervical cancer which can reduce the overall disease burden and improve patients' life expectancy.
\end{abstract}




\section{TABLE OF CONTENTS}

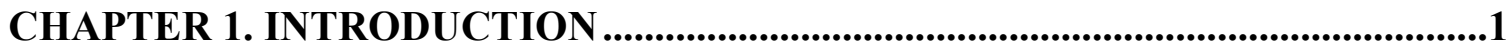

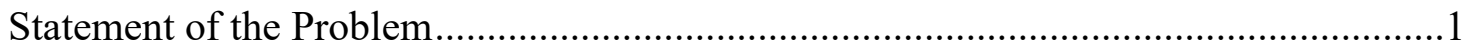

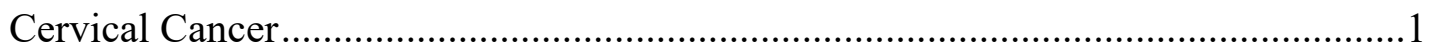

Cervical Cancer and Human Papillomavirus ............................................................ 1

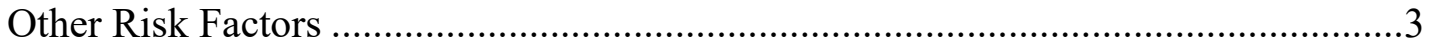

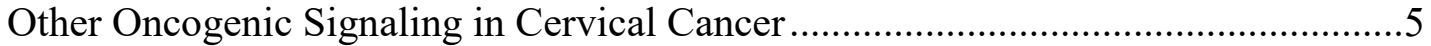

Current Available Treatments and Their Limitations ..................................................5

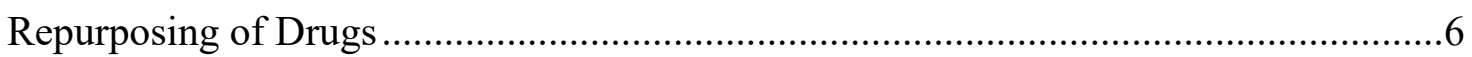

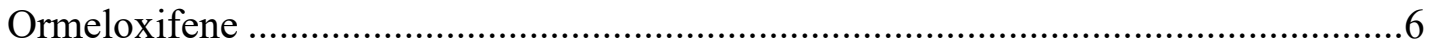

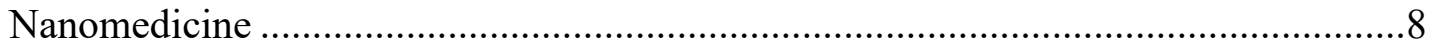

\section{CHAPTER 2. EVALUATION OF ANTI-PROLIFERATIVE ACTIVITY OF} ORMELOXIFENE IN CERVICAL CANCER CELLS ...........................................10

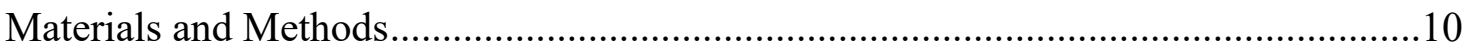

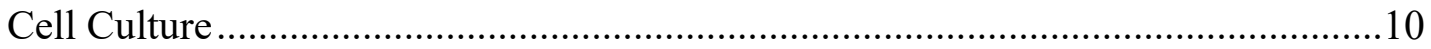

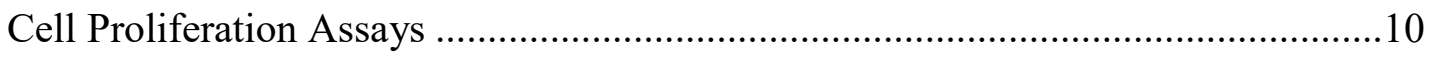

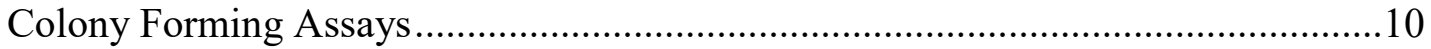

Real Time Cell Proliferation Kinetic Assay through xCELLigence System.............11

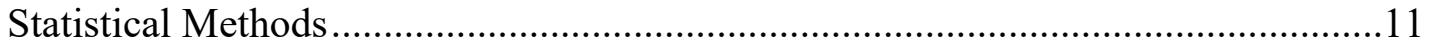

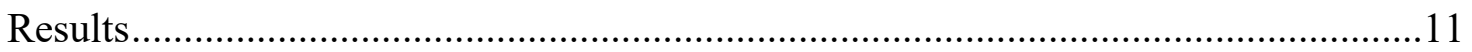

Ormeloxifene Treatment Inhibits Cellular Proliferation of Various Cervical

Cancer Cells .......................................................................................................... 11

Ormeloxifene Treatment Inhibits Clonogenic Potential of Various Cervical

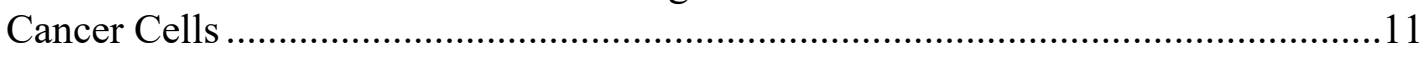

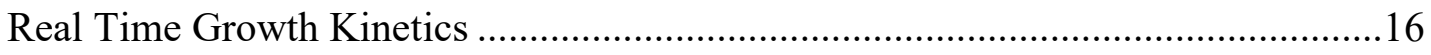

\section{CHAPTER 3. DETERMINATION OF ANTI-MOTILITY PROPERTITES OF} ORMELOXIFENE IN CERVICAL CANCER CELLS ........................................22

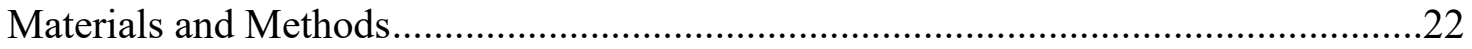

Agarose Bead Assay ........................................................................................ 22

Boyden Chamber Cell Migration Assay ...........................................................22

Boyden Chamber Matrigel Cell Invasion Assay ................................................22

Real Time Migration and Invasion Assays through xCELLigence System .............23

Statistical Methods ..........................................................................................2 23

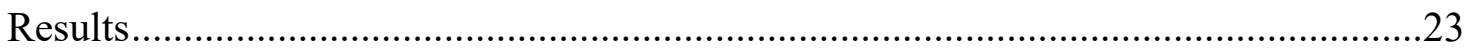

\section{CHAPTER 4. ASSESSMENT OF APOPTOSIS INDUCING ABILITY OF} ORMELOXIFENE IN CERVICAL CANCER CELLS ......................................29

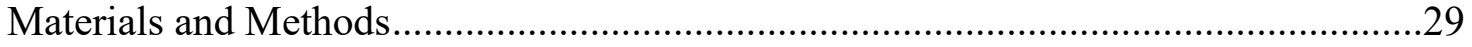

Morphology Visualization with Phase Contrast Microscopy ….............................29

Mitochondrial Membrane Potential ..................................................................29

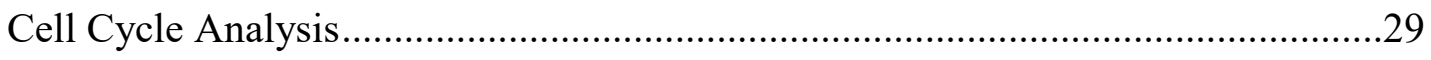




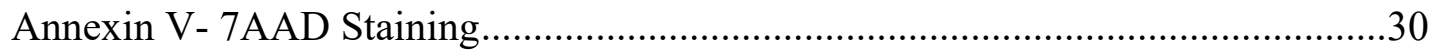

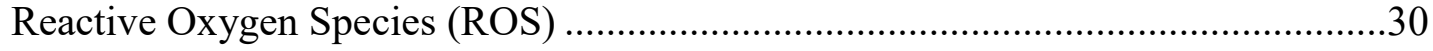

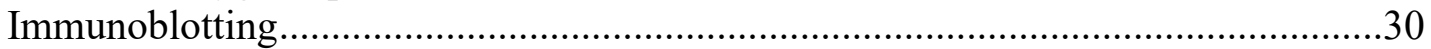

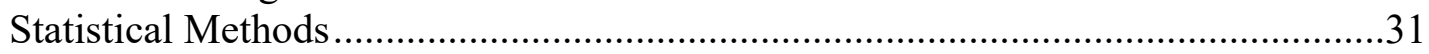

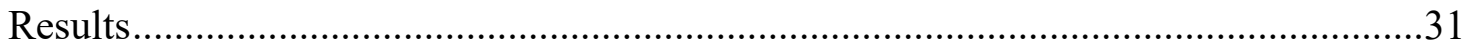

Ormeloxifene Alters the Morphology of Cervical Cancer Cells .................................31

Ormeloxifene Induces Mitochondrial Membrane Potential.........................................31

Ormeloxifene Induces Generation of Reactive Oxygen Species ................................31

Ormeloxifene Induces Apoptosis in Cervical Cancer Cells ........................................37

Ormeloxifene Arrest Cell Cycle in G1-S Transition by Regulating the

Expression Level of Transition Related Proteins.........................................................37

Ormeloxifene Downregulates PI3K-Akt Pathway......................................................37

\section{CHAPTER 5. ANALYSIS OF ORMELOXIFENE'S EFFECT ON HPV REGULATION ONCOGENESIS IN CERVICAL CANCER .....................................51}

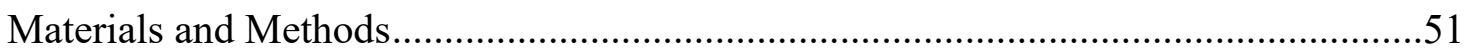

Quantitative PCR …………………………………................................51

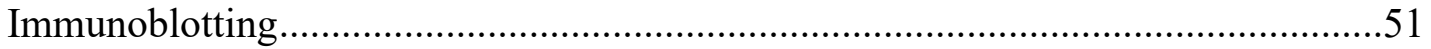

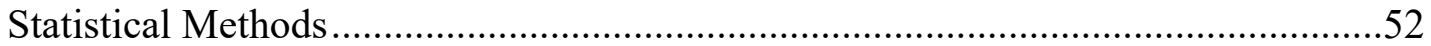

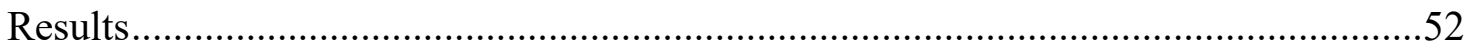

Ormeloxifene Decreases the Expression of HPV Oncogenes E6 and E7 ...................52

Ormeloxifene Restores the Tumor Suppressor Signaling.........................................52

\section{CHAPTER 6. IN VITRO EXAMINATION OF ORMELOXIFENE WITH} RADIATION AS A COMBINATION THERAPY......................................................62

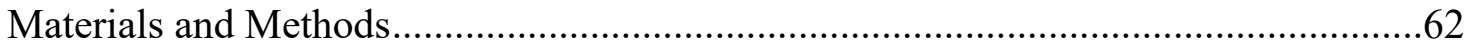

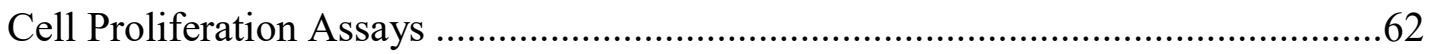

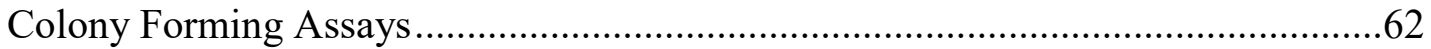

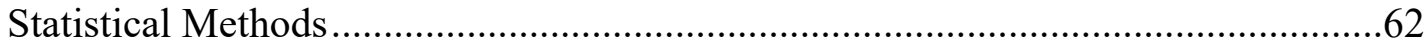

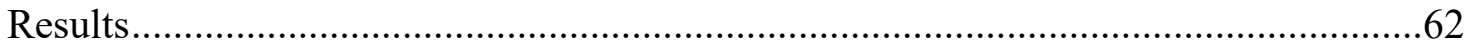

\section{CHAPTER 7. DEVELOPMENT AND PHYSICOCHEMICAL}

CHARACTERIZATION OF ORMELOXIFENE LOADED PLGA

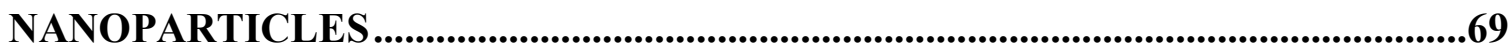

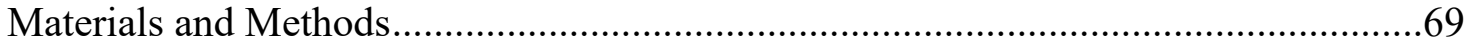

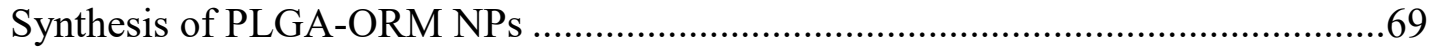

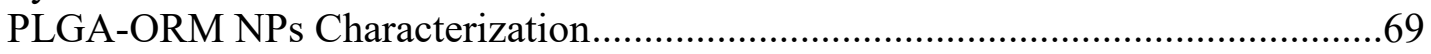

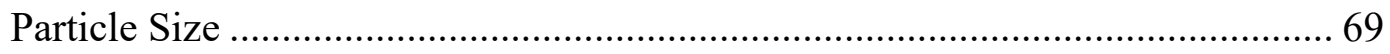

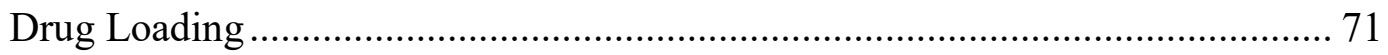

Fourier Transform Infra-Red ..................................................................... 71

Thermal Analysis .................................................................................... 71

In Vitro Drug Release (Dialysis Bag Method).................................................... 71

Colloidal Stability of Nanoparticles in Whole Human Serum Albumin (WHSA) 73

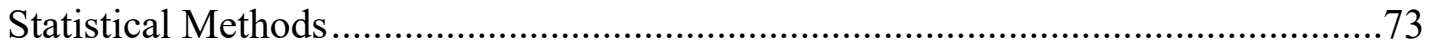

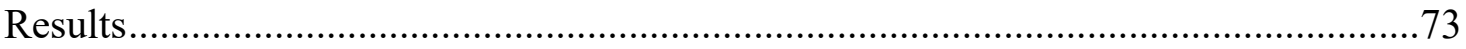

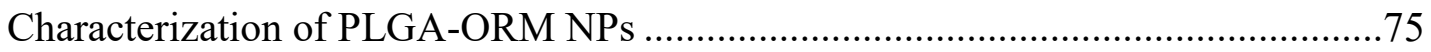


In vitro Release Profile

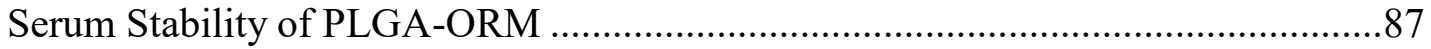

\section{CHAPTER 8. EVALUATION OF IN VITRO UPTAKE AND ANTI-} PROLIFERATIVE ACTIVITY OF PLGA-ORM .........................................................89

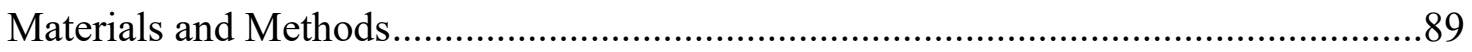

Cellular Internalization of Nano-ORM in Caski and SiHa Cervical Cancer Cells....89

Transmission Electron Microscopy (TEM) .........................................................8

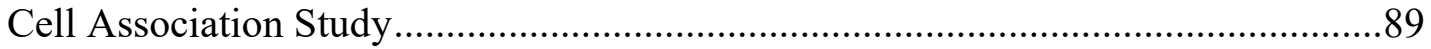

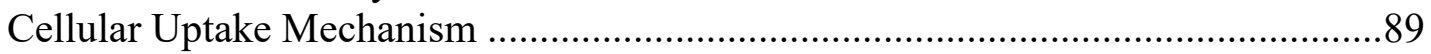

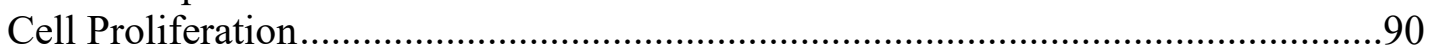

Colony Formation Assay .....................................................................................90

Real Time Cell Proliferation Kinetic Assay Using xCELLigence System.................90

Mitochondrial Membrane Potential by TMRE …………………………….............91

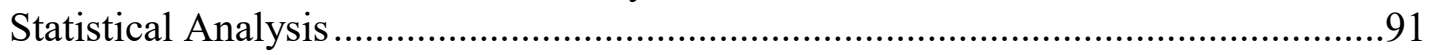

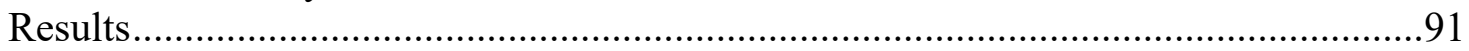

PLGA-ORM Nanoparticles Internalize in Cervical Cancer Cells .............................91

PLGA-ORM Nanoparticles Utilizes Endocytosis Pathway for Internalization in Cervical Cancer Cells .........................................................................................

PLGA-ORM Decreases Cellular Viability, Clonogenic Potential and

Mitochondrial Membrane Potential of Cervical Cancer Cells...................................101

\section{CHAPTER 9. IN VIVO VALIDATION OF ANTI-CANCEROUS/TUMOROUS} FUNCTION OF ORMELOXIFENE AND PLGA-ORM ............................................112

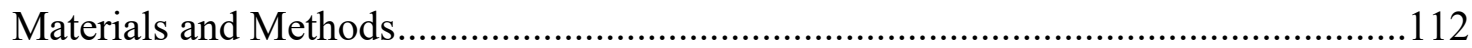

In vivo Orthotopic Tumoral Study ……………………...................................112

Statistical Analysis .....................................................................................112

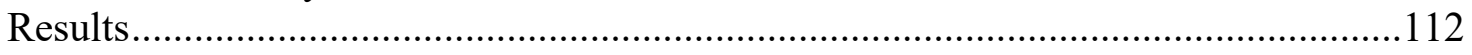

CHAPTER 10. DISCUSSION........................................................................................118

LIST OF REFERENCES ....................................................................................................121

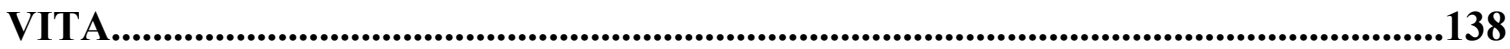




\section{LIST OF FIGURES}

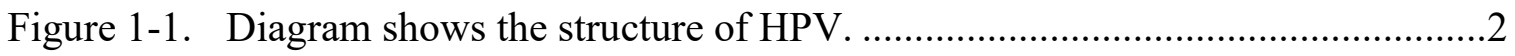

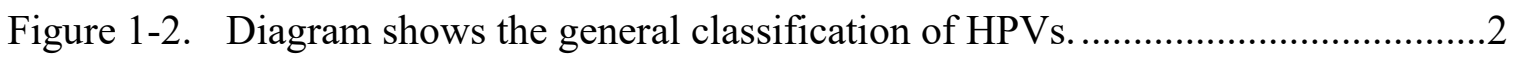

Figure 1-3. A schematic of cell cycle progression. ……………......................................

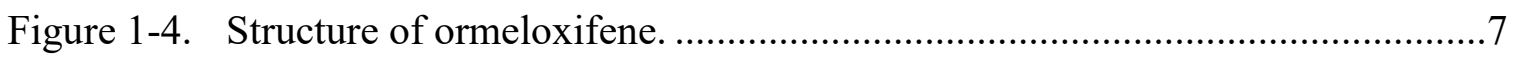

Figure 1-5. Diagram shows EPR (enhanced permeation and retention) effect. ................9

Figure 2-1. Ormeloxifene decreased cellular proliferation of Caski cells.......................12

Figure 2-2. Ormeloxifene decreased cellular proliferation of $\mathrm{SiHa}$ cells........................13

Figure 2-3. Ormeloxifene decreased cellular proliferation of C33A cells. .......................14

Figure 2-4. Ormeloxifene decreased cellular proliferation of HT3 cells..........................15

Figure 2-5. Ormeloxifene inhibited clonogenic potential of Caski cells..........................16

Figure 2-6. Bar graph showing that Ormeloxifene inhibited clonogenic potential of Caski cells. .............................................................................................

Figure 2-7. Ormeloxifene inhibited clonogenic potential of $\mathrm{SiHa}$ cells..........................17

Figure 2-8. Bar graph showing that Ormeloxifene inhibited clonogenic potential of

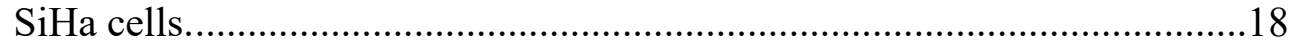

Figure 2-9. Ormeloxifene inhibited clonogenic potential of C33A cells........................18

Figure 2-10. Bar graph showing that Ormeloxifene inhibited clonogenic potential of C33A cells.

Figure 2-11. Ormeloxifene inhibited clonogenic potential of HT3 cells.

Figure 2-12. Bar graph showing that Ormeloxifene inhibited clonogenic potential of HT3 cells.

Figure 2-13. Ormeloxifene inhibited growth of Caski cells in real time...........................21

Figure 2-14. Ormeloxifene inhibited growth of $\mathrm{SiHa}$ cells in real time.

Figure 3-1. Ormeloxifene decreased cellular motility of Caski cells confirmed through agarose bead assay. 
Figure 3-2. Ormeloxifene decreased cellular motility of SiHa cells confirmed through agarose bead assay.

Figure 3-3. Ormeloxifene decreased cellular migration of Caski cells confirmed through Boyden chamber migration assay.

Figure 3-4. Ormeloxifene decreased cellular migration of SiHa cells confirmed through Boyden chamber migration assay.

Figure 3-5. Ormeloxifene decreased cellular invasion of Caski cells confirmed through Boyden chamber matrigel invasion assay. .26

Figure 3-6. Ormeloxifene decreased cellular invasion of SiHa cells confirmed through Boyden chamber matrigel invasion assay.

Figure 3-7. Ormeloxifene inhibited migration of Caski cells in real time.

Figure 3-8. Ormeloxifene inhibited migration of SiHa cells in real time.

Figure 3-9. Ormeloxifene inhibited invasion of Caski cells in real time........................28

Figure 3-10. Ormeloxifene inhibited invasion of $\mathrm{SiHa}$ cells in real time. .28

Figure 4-1. Ormeloxifene altered morphology of Caski cells. 32

Figure 4-2. Ormeloxifene altered morphology of SiHa cells. .32

Figure 4-3. Ormeloxifene decreased mitochondrial membrane potential of Caski cells.

Figure 4-4. Ormeloxifene decreased mitochondrial membrane potential of $\mathrm{SiHa}$ cells.

Figure 4-5. Ormeloxifene decreased mitochondrial membrane potential (MMP) of Caski cells.

Figure 4-6. Ormeloxifene decreased mitochondrial membrane potential (MMP) of $\mathrm{SiHa}$ cells.

Figure 4-7. Ormeloxifene enhanced the generation of reactive oxygen species (ROS) in Caski cells.

Figure 4-8. Ormeloxifene enhanced the generation of reactive oxygen species (ROS) in $\mathrm{SiHa}$ cells.

Figure 4-9. Cell population diagram of Caski cells obtained with Flow Cytometer representing percentage of cells stained with either Annexin V or 7AAD or both or none. 
Figure 4-10. Cell population diagram of SiHa cells obtained with Flow Cytometer representing percentage of cells stained with either Annexin V or 7AAD or both or none.

Figure 4-11.Ormeloxifene induced apoptosis of Caski cells.

Figure 4-12. Ormeloxifene induced apoptosis of SiHa cells.

Figure 4-13. Ormeloxifene arrested cell cycle at G1-S transition in Caski Cells

Figure 4-14. Ormeloxifene arrested cell cycle at G1-S transition in SiHa cells

Figure 4-15. Ormeloxifene downregulated the expression levels of Cyclin E and Cdk2 in Caski cells.

Figure 4-16. Densitometric quantitation of band intensity of Cyclin E. ...........................45

Figure 4-17. Densitometric quantitation of band intensity of Cdk2 ................................46

Figure 4-18. Ormeloxifene downregulated the expression levels of PI3K/Akt pathway in Caski cells.

Figure 4-19. Densitometric quantitation of band intensity of PI3K.................................48

Figure 4-20. Densitometric quantitation of band intensity of pAkt...................................49

Figure 4-21. Densitometric quantitation of band intensity of Akt.....................................50

Figure 5-1. Ormeloxifene decreased HPV E6 mRNA.....................................................53

Figure 5-2. Ormeloxifene decreased HPV E7 mRNA...................................................54

Figure 5-3. Ormeloxifene inhibited HPV E6 and E7 proteins.........................................55

Figure 5-4. Densitometric quantitation of band intensity of HPV E6...........................56

Figure 5-5. Densitometric quantitation of band intensity of HPV E7. ............................57

Figure 5-6. Ormeloxifene restored the expression levels of p53, Rb and PTPN13 tumor suppressor proteins. …………………………...............................58

Figure 5-7. Densitometric quantitation of band intensity of p53....................................59

Figure 5-8. Densitometric quantitation of band intensity of $\mathrm{Rb}$....................................60

Figure 5-9. Densitometric quantitation of band intensity of PTPN13 _...........................61

Figure 6-1. Caski cells were pretreated with ormeloxifene and exposed to radiation.....63 
Figure 6-2. Caski cells were pretreated with ormeloxifene and exposed to radiation and cells were counted with Coulter counter.

Figure 6-3. Caski cells were treated with ormeloxifene and exposed to radiation simultaneously.

Figure 6-4. Caski Cells were treated with ormeloxifene and exposed to radiation simultaneously and cells were counted with Coulter counter.

Figure 6-5. Combination treatment of ormeloxifene and radiation reduced the clonogenic potential of Caski cells.

Figure 6-6. Bar graph showing that combination treatment of ormeloxifene and radiation reduced the clonogenic potential of Caski cells.

Figure 7-1. Diagram showing preparation method (nano-precipitation) of PLGA-

ORM nanoformulation.

Figure 7-2. Representation of in vitro drug release in house system

Figure 7-3. Schematic of PLGA-ORM NP formulations.

Figure 7-4. Representative TEM images of PLGA alone nanoparticles and Scale bars on TEM images equal $200 \mathrm{~nm}$.

Figure 7-5. Representative TEM images of PLGA-ORM 5 nanoparticles and Scale bars on TEM images equal $200 \mathrm{~nm}$.

Figure 7-6. Representative TEM images of PLGA-ORM 10 nanoparticles and Scale bars on TEM images equal $200 \mathrm{~nm}$.

Figure 7-7. Representative TEM images of PLGA-ORM 15 nanoparticles and Scale bars on TEM images equal $200 \mathrm{~nm}$.

Figure 7-8. Representative TEM images of PLGA-ORM 20 nanoparticles and Scale bars on TEM images equal $200 \mathrm{~nm}$.

Figure 7-9. Representative TEM images of PLGA-ORM 25 nanoparticles and Scale bars on TEM images equal $200 \mathrm{~nm}$.

Figure 7-10. Evaluation of nanoparticle size from TEM images using ImageJ software, data represents an average of at least 20 particles in two different fields of view in TEM images.

Figure 7-11. PLGA-ORM particle size representation using DLS system.

Figure 7-12. FT-IR spectra of ORM, PLGA NPs and PLGA-ORM NP formulations confirmed that ormeloxifene is successfully encapsulated in PLGA core...84 
Figure 7-13. DSC endothermic curves of PLGA and PLGA-ORM NP nanoformulations confirmed that ormeloxifene is successfully encapsulated in PLGA core.

Figure 7-14. Thermogravimetric weight loss curves of PLGA and PLGA-ORM NP nanoformulations suggested ORM's successful incorporation in the PLGA-ORM NP formulation.

Figure 7-15. Sustained in vitro release profile of PLGA-ORM. .88

Figure 7-16. Whole human serum stability profile of PLGA-ORM. .88

Figure 8-1. Qualitative representation of cellular uptake of coumarin-6 loaded PLGA-ORM nanoparticles in Caski cells.

Figure 8-2. Coumarin-6 loaded PLGA-ORM internalization in Caski cells.

Figure 8-3. Qualitative representation of cellular uptake of coumarin-6 loaded PLGA-ORM nanoparticles in SiHa cells.

Figure 8-4. Coumarin-6 loaded PLGA-ORM internalization in SiHa cells. . .94

Figure 8-5. Cellular internalization of free ORM in Caski cells showed by TEM.........95

Figure 8-6. Cellular internalization of PLGA-ORM in Caski cells showed by TEM....96

Figure 8-7. Cellular internalization of free ORM in SiHa cells showed by TEM..........97

Figure 8-8. Cellular internalization of PLGA-ORM in SiHa cells showed by TEM. .....98

Figure 8-9. Internalization of Coumarin-6 loaded PLGA-ORM is energy dependent in Caski cells.

Figure 8-10. Internalization of Coumarin-6 loaded PLGA-ORM is energy dependent in $\mathrm{SiHa}$ cells. 100

Figure 8-11. Representation of different endocytosis pathway and their inhibitors 102

Figure 8-12. PLGA-ORM nanoparticles entered Caski cells using endocytosis pathway.

Figure 8-13. PLGA-ORM nanoparticles entered SiHa cells using endocytosis pathway. 104

Figure 8-14. PLGA-ORM decreased cellular proliferation of Caski cells. 105

Figure 8-15. PLGA-ORM decreased cellular proliferation of SiHa cells. 106

Figure 8-16. PLGA-ORM decreased colony forming ability of Caski cells. 106 
Figure 8-17. Bar graph showing that PLGA-ORM decreased colony forming ability of Caski cells. .....

Figure 8-18. PLGA-ORM decreased colony forming ability of SiHa cells.

Figure 8-19. Bar graph showing that PLGA-ORM decreased colony forming ability of SiHa cells.

Figure 8-20. PLGA-ORM inhibited growth of Caski cells in real time.

Figure 8-21. PLGA-ORM inhibited growth of SiHa cells in real time.

Figure 8-22. PLGA-ORM reduced mitochondrial membrane potential of Caski cells as measured by TMRE stain using flow cytometer.

Figure 8-23. PLGA-ORM reduced mitochondrial membrane potential of SiHa cells as measured by TMRE stain using flow cytometer.

Figure 9-1. Schematic of in vivo study.

Figure 9-2. Images represent mice from different treatment groups and their dissected tumors

Figure 9-3. PLGA-ORM inhibited tumor growth of cervical cancer orthotopic mice model.

Figure 9-4. Weight measurement from the tumors dissected from mice.

Figure 9-5. Percent survival curve for ORM and PLGA-ORM treated mice. 


\section{LIST OF ABBREVIATIONS}

\begin{tabular}{|c|c|}
\hline $\mathrm{CxCa}$ & Cervical Cancer \\
\hline ORM & Ormeloxifene \\
\hline PLGA & Poly(lactic-co-glycolic acid) \\
\hline RAD & Radiation \\
\hline MMP & Mitochondrial membrane potential \\
\hline $\operatorname{hr}(\mathrm{s})$ & Hour(s) \\
\hline $\min$ & Minute \\
\hline HPV & Human papillomavirus \\
\hline $\mathrm{Rb}$ & Retinoblastoma protein \\
\hline p53 & Protein 53 \\
\hline TEM & Transmission electron microscopy \\
\hline DLS & Dynamic light scattering \\
\hline$\mu$ & Micro \\
\hline C6 & Coumarin 6 \\
\hline TMRE & Tetramethylrhodamine, ethyl ester \\
\hline $\mathrm{NP}(\mathrm{s})$ & Nanoparticle(s) \\
\hline EPR & Enhanced permeation and retentio \\
\hline
\end{tabular}




\title{
CHAPTER 1. INTRODUCTION*
}

\author{
Statement of the Problem
}

\section{Cervical Cancer}

Cervical cancer stands at the fourth rank among most common and deadly malignancies in women globally. In the year of 2012, cervical cancer accounted for 528,000 new cases and 266,000 death incidences around the world. Incidence rates remain higher in less developed countries $(15.7 \%)$ than more developed countries $(9.9 \%)$ mainly in Eastern (42.7\%), Middle (30.6\%) and South Africa (31.5\%) [1]. In developing countries this is the major cause in women who are at reproductive age and the reason being is less awareness and availability of screening modalities [2-4].

\section{Cervical Cancer and Human Papillomavirus}

Cervical cancer is primarily associated with the high risk Human Papillomavirus (HPV) infection [5-9]. HPV's are circular, double stranded DNA viruses consisting of about 8000 base pairs (Figure 1-1) [10-14] and are the most common type of sexually transmitted virus infection [15-17]. Upon the classification, there are more than 100 well known human papillomaviruses which are further divided in to two categories - High Risk and Low Risk (Figure 1-2) [18]. Persistent infection of any of these 13 High risk HPV's (HVP 16, 18, 31, 33, 35, 39,45, 51, 52, 56, 59 and 66) can result in the progression of cervical cancer $[19,20]$ while Low Risk HPVs such as 2, 4, 5, 10 and 15 are known to cause warts [21-23]. HPV 16 and 18 are the most shared type of HPVs and account for about $70 \%$ of invasive cervical cancer cases [24]. Like other cancers, cervical cancer also has various changes at genetic level, loss of $11 \mathrm{q}$ and gain of $3 \mathrm{q}$ are a common characteristic change in HPV positive cells $[25,26]$. HPV infection can either be latent or active [27], if the virus completes its life cycle then it is a latent infection [28]. When a virus completes the life cycle, huge production of viral progeny is desired which is carried out by the HPV replication protein E1 and mainly E2 [29]. E2 is the major player in HPV life cycle which controls the expression of other viral genes [30]. When the virus starts integrating in to host cell genome, this event deregulates the E2 replication protein, this deregulation of E2 eventually leads to the increased expression of E6 and E7 as they are repressed by E2 [30]. During the life cycle, E6 and E7 are expressed at the lower epithelial layer of cells where these two proteins facilitate cells as they move from $\mathrm{G} 1$ cell cycle phase to $\mathrm{S}$ phase which is the synthesis phase, thus, expression of HPV E6 and E7 results in elevated rate of cell proliferation [31-33]. Capsid

\footnotetext{
* Adapted with permission. Khan, S., et al., Nanoparticle formulation of ormeloxifene for pancreatic cancer. Biomaterials, 2015. 53: p. 731-743.
} 


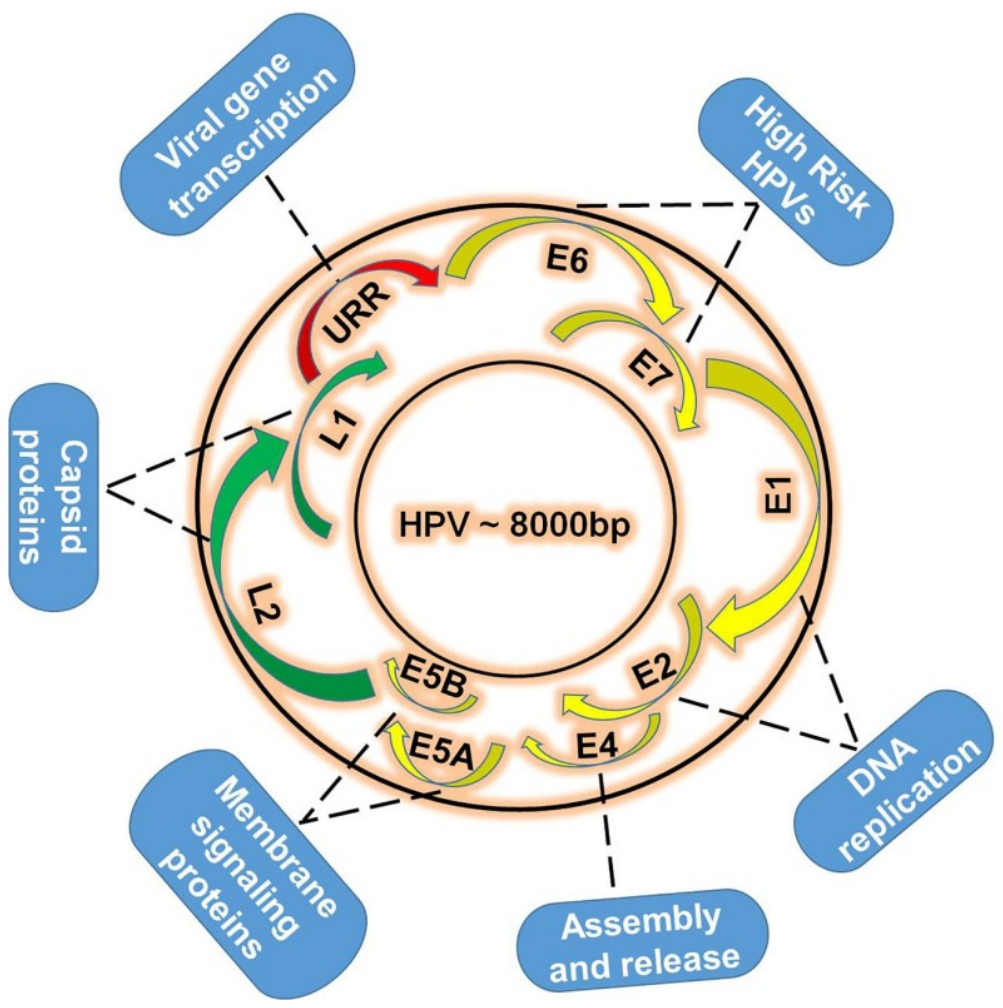

Figure 1-1. Diagram shows the structure of HPV.

Modified with permission. Yugawa, T. and T. Kiyono, Molecular mechanisms of cervical carcinogenesis by high-risk human papillomaviruses: novel functions of E6 and E7 oncoproteins. Reviews in medical virology, 2009. 19(2): p. 97-113.

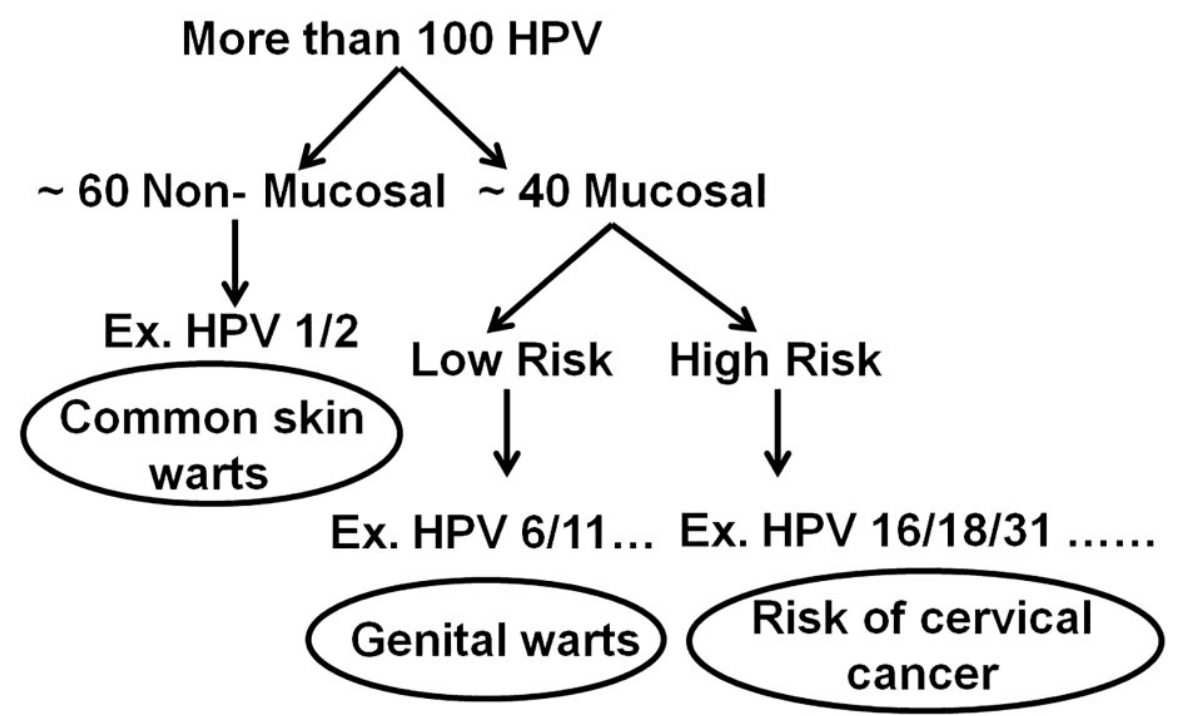

Figure 1-2. Diagram shows the general classification of HPVs. 
proteins L1 and L2 are expressed at the upper epithelial layer cells along with E4 to gather and provide structure to the progenies [28]. Malignant cervical cancer cells specifically express two viral oncoproteins HPV E6 and E7 [34]. HPV E6 and E7 are known to cause genomic alterations resulting in gain or loss of function of genes in various cancers including cervical cancer $[25,26]$. E6 and E7 disturb the functions of p53 (protein 53) and $\mathrm{Rb}$ (Retinoblastoma protein), two tumor suppressor proteins. Both the proteins regulate cell cycle progression and excessive cell proliferation. The E6 binds to p53 and degrades it by proteosomal degradation [35, 36]. Whereas the E7 oncoprotein binds to $\mathrm{Rb}$ and degrades it which leads to the induction of cell growth and gene promoting DNA synthesis $[37,38]$. Rb specifically $(\mathrm{pRb})$ binds to the E2F which is transcription factor, and prevents E2F from interacting with other cyclins and cyclin dependent kinases, thus, inhibiting proliferation. But upon the binding of E7, pRB cannot perform this preventive action on E2F which allows E2F to interact with other cyclins and thus, promotes cell proliferation and cell cycle progression (Figure 1-3) [39-42]. PTPN 13 is a nonreceptor phosphatase that also gets degraded by HPV E6 upon its binding [43].

\section{Other Risk Factors}

Though HPV is the most common factor of cervical cancer yet alone it is not enough to develop cervical cancer and requires other risk factors such as smoking, multiple sexual partners, and first intercourse at young age, use of oral contraceptives and low socioeconomic status [44-47]. Some case control studies show an establishment between the use of oral contraception and development of cervical cancer but the studies are of poor quality and data is inconsistent and insignificant as the confidence interval values (CIs) were wide [48-50]. Also, there is a good number of studies which report that association between oral contraceptive and HPV infection/ cervical cancer is just due to the reason that women already being on one type of birth control strategy are very likely not to use other protection system, thus are more prone to get infection via sexual contacts [51-54]. Among females, cigarette smoking has two times higher risk of having cervical cancer than those who do not smoke [16], even the secondary exposure to cigarette smoke has been associated with the incidences of cervical cancer [55, 56]. A well-known cigarette smoke carcinogen, BaP (Banzo[a]pyrene increases the expression levels of HPV oncoproteins E6 and E7 in cervical cancer cells [57]. There are reports that suggest that cigarette smoke residuals are found in the mucus sample of women who smoke [58-60]. Epidemiology of cervical cancer suggests that having multiple sexual partners and young age at first sexual intercourse, increases the risk for HPV infection and development of cervical cancer among women [61, 62]. One other risk factor that also contributes toward developing cervical cancer, is elevated hormones especially estrogen and progesterone during the pregnancies which effects the HPV regulation in the system [63]. There is a link between estrogen receptor $\alpha$ and cervical cancer tumorigenesis. Estrogen receptor $\alpha$ promotes tumor development in HPV transgenic cervical cancer mice model where as mice that were given no estrogen receptor showed 


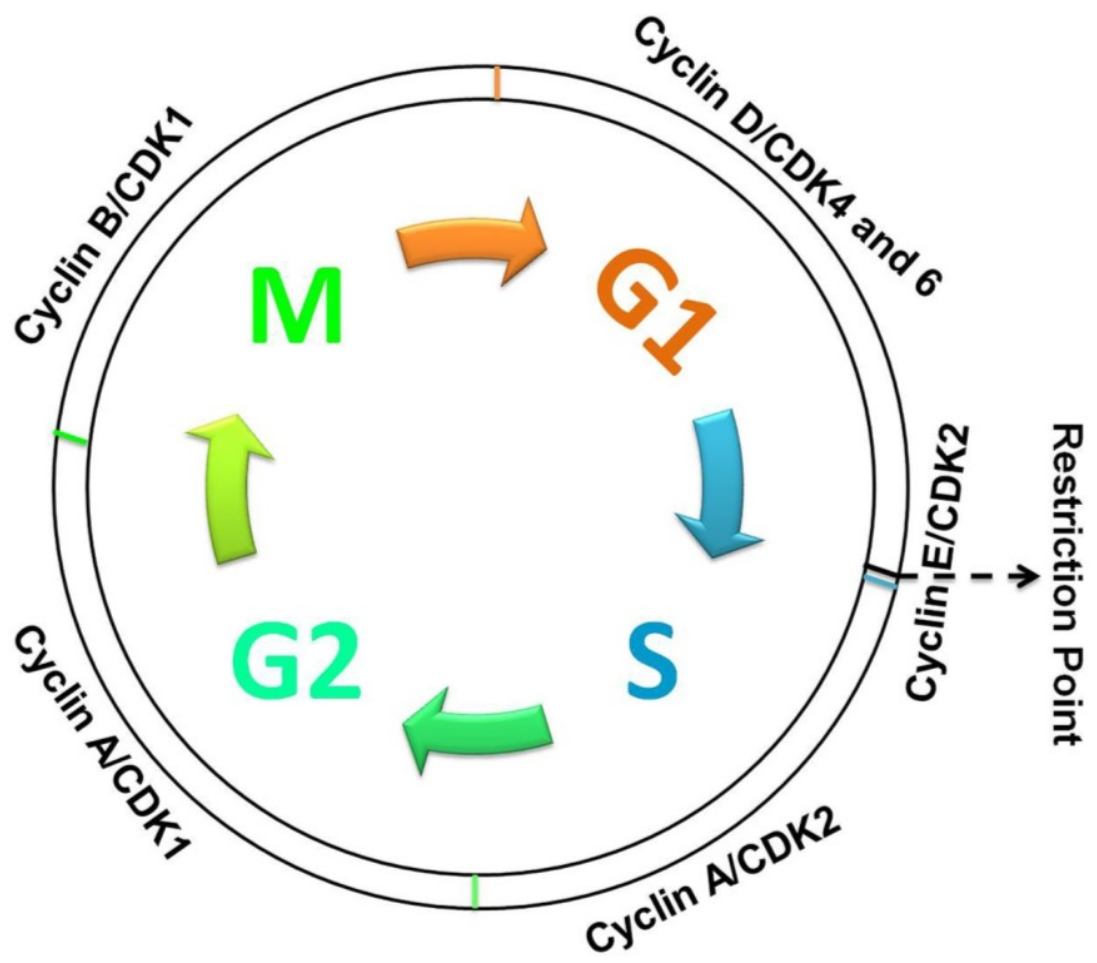

Figure 1-3. A schematic of cell cycle progression.

Modified with permission. Dehay, C. and H. Kennedy, Cell-cycle control and cortical development. Nature Reviews Neuroscience, 2007. 8(6): p. 438-450. 
no symptoms of developing tumors. Therefore, molecules that can target estrogen receptor, hold great promises to become anti-cervical cancer agents [64].

\section{Other Oncogenic Signaling in Cervical Cancer}

It is known that HPV infection changes or modulates different signaling pathways which eventually leads to the induction of cervical cancer [65]. HPV signaling needs few other different pathways in order to promote cell survival and proliferation namely Ras, Notch receptor, Growth factor receptor and PI3KCA [66-69]. PI3K-Akt signaling gets modulated and activated by HPV E6 and E7 [70, 71]. PI3K-Akt is a cell survival pathway which is responsible for many cellular functions such as cell proliferation, cell survival and cell cycle progression in variety of cancers [72-74]. PI3K-Akt is one of the most aberrantly expressed pathways in cervical cancer cells [75-78]. Akt becomes phosphorylated at serine and threonine residuals by the overexpression of PI3K [79] and thus, gets activated for the further initiation of apoptosis cascade [80]. Human cervical cancer tissue samples express the increased levels of pAkt [81], therefore, PI3K-Akt signaling pathway has gained much attention for the therapeutic aspects in cervical cancer [82].

\section{Current Available Treatments and Their Limitations}

In many developed countries Pap Smear Screening (Pap test) is available to detect the pre-cancerous changes at the cervix which has greatly reduced the incidences (occurrence) of cervical cancer as the pre-cancerous lesions can be detected and followed up by treatments, [54] but it is also reported that Pap screening results in almost about $20 \%$ of false negative results [83]. HPV testing is also available for the detection of high risk HPVs alone or in the combination with Pap test [84]. Being a viral disease, there are many vaccines generated and available too for prevention purposes of cervical cancer [85]. Gardasil and Cervarix are two approved vaccines that are in human use and provide $100 \%$ protection against HPV 16 and 18 which has been reported to last up to 8-9 years [86-88]. Current treatment modalities available for the management of cervical cancer are disease stage dependent; early stage patients are mainly advised surgery or radiotherapy $[89,90]$ whereas late stages of cervical cancer are tackled by radiation along with cisplatin based chemotherapy [91].

Although cervical cancer is highly preventable, yet the mortality rate remains high and reasons are the limitations and drawbacks of current prevention and treatment modalities. The available vaccines for preventing the disease have age limitation. They are suggested to use between the ages of 13 to 26 but vaccination can be started as early as at age 11 [92]. The other treatment methods such as surgery, radiation and chemotherapy have their own adverse effects. Patients often suffer from weakness, fatigue, weight loss, appetite loss and infertility. Despite of having many current available treatment choices, $100 \%$ success rate is not guaranteed and usual recurrence time is 2 years [93-95]. 


\section{Repurposing of Drugs}

According to an estimate it takes almost 15-20 years and about \$800 million USD of cost to get a new drug entity to the market $[96,97]$ and that too comes with constraint of Food and Drug Administration (FDA) as FDA only approves less than 30 new compounds every year $[97,98]$. All these obstacles make it difficult to discover new drugs for cancer management [99]. In order to overcome this issue one proposed mechanism is to reuse the drugs that are already in market for other uses [100]. This newer approach is called "drug repositioning" or "drug repurposing" or "drug reprofiling" or "therapeutic switching" [101]. There are various molecules that have been repurposed for cancer treatment. Some of the illustrations given here are recent studies with metformin on various cancer treatments [102-104] which traditionally is an antidiabetic molecule [105]. Aspirin which is a very well know analgesic has been established as a potent anti-cancer molecule for metastatic lung cancer [106], as well as brain, esophageal, pancreatic and gastrointestinal [107], and it is also reported that long term (up to 5 years) daily consumption of aspirin can reduce the risk of developing colorectal cancer [108]. Another very well described example of drug-repositioning is rapamycin which is a known inhibitor of mTOR pathway which is highly expressed in various cancers [109]. Therefore, rapamycin has been studied for its anti-cancer properties and it shows brilliant anti-tumorous activities for myeloid leukemia [110] and myelogenous leukemia [111].

\section{Ormeloxifene}

Ormeloxifene (Centchroman), $\mathrm{C}_{30} \mathrm{H}_{35} \mathrm{O}_{3} \mathrm{~N}$.HCl, (Figure 1-4) [112] is a nonsteroidal, non-hormonal anti-estrogen oral contraceptive for human use that is taken once per week and was first synthesized by Central Drug Research Institute, India [113]. Ormeloxifene is a SERM (Selective Estrogen Receptor Modulator) which inhibits estrogen receptors (ER) in uterus, cervix, ovary and breast while promoting these receptors in other organs such as bones $[114,115]$. Ormeloxifene is a crystalline molecule, white in color and has a molecular weight of 493.5Da. It is insoluble in water but soluble in ethanol, methanol, acetone and chloroform (organic solvents) $[114,116]$. Ormeloxifene is stable at room temperature and $4{ }^{\circ} \mathrm{C}$ with maintaining its biological activities [117]. Ormeloxifene showed excellent pharmacokinetic and pharmacodynamics properties with low binding affinity toward human plasma proteins and no affinity toward steroids present in the body [118-123]. Ormeloxifene is generally metabolized by liver but if high amounts of the drug are provided, traces can be found in spleen, lungs and uterus $[124,125]$. In animals (adult female rats) the half-life of the drug is about 24 hours when administered orally using $12.5 \mathrm{mg} / \mathrm{kg}$ of ormeloxifene [124]. While in humans (adult healthy females) the half-life of ormeloxifene is around 168 hours when administered orally with either $30 \mathrm{mg}$ or $60 \mathrm{mg}$ of dose [126]. Recent studies have repurposed ormeloxifene for its anti-cancer properties namely; it inhibits cell proliferation/growth and motility, moreover, it was reported to block cell cycle and induce apoptosis [127]. Previous studies suggest that ormeloxifene has strong anti-breast 


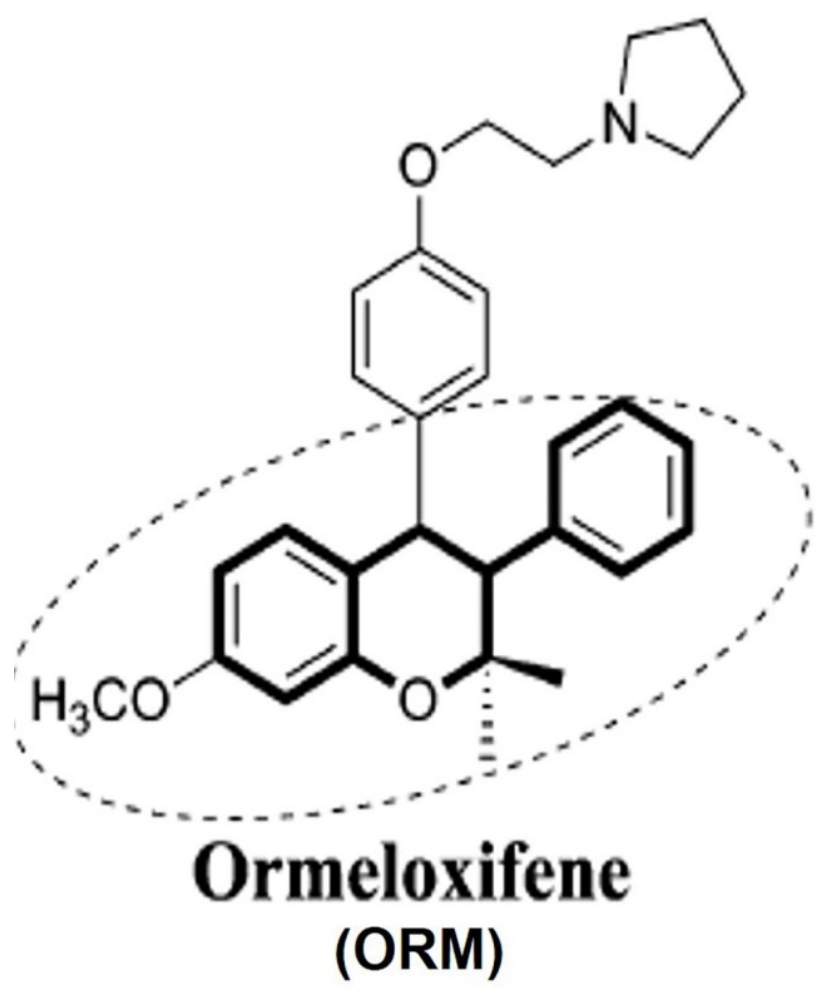

Figure 1-4. Structure of ormeloxifene.

Modified with permission. Kumar, R., et al., Selective estrogen receptor modulators regulate stromal proliferation in human benign prostatic hyperplasia by multiple beneficial mechanisms - action of two new agents. Investigational new drugs, 2012. 30(2): p. 582-593. 
cancer [113] and anti-head and neck cancer properties [128]. Ormeloxifene has been used as an anti-neoplastic agent in MCF-7/ MDA MB-231 Estrogen Receptor (ER \pm ve) Human Breast Cancer Cells (HBCCs) [129, 130]. Moreover, ormeloxifene works excellently in combinational therapies as well with curcumin or resveratrol [131] and with glycine soya [132] against breast cancer. Results from these studies suggest that ormeloxifene works with both ER dependent and ER independent mechanisms and also it seems to work through various different other pathways such as PI3K-Akt, STAT3 and SHH. Another study shows that not only solid tumors but ormeloxifene also targets hematological tumors such as chronic myeloid leukemia [133]. Our group has recently published that ormeloxifene also has potent anti-pancreatic [134] and anti-ovarian [135] cancers properties.

\section{Nanomedicine}

Nanotechnology is a newer therapeutic approach with great success over traditional chemotherapy [136-139]. Nanoparticles have a suggested size range of 100$300 \mathrm{~nm}[138,140]$. Size is the most important consideration while designing a nanomedicine as it decides the fate of nanoparticle's cellular uptake [141-143] and biodistribution [144-146]. Particle size that is lesser than 5-10 $\mathrm{nm}$ is rapidly cleared by kidneys [146, 147]. Also, particle size that is around $15 \mu \mathrm{m}$ tends to accumulate in liver and spleen [148-150]. Nanoparticle formulations provide targeted delivery of drugs along with improved bioavailability in the system, thus, they are an attractive tool for evolving newer treatment patterns for cancer [151-154]. Free drugs are not site-specific when delivered to the body while modern methodology of nano-carriers facilitates the sitespecific targeted delivery of drugs [155-157]. Due to the leaky vasculature of the tumor and enhanced permeation and retention (EPR) effect (Figure 1-5) [157-159], nanodrugs can specifically be entrapped and accumulated into tumors [160-162]. Initial nanoparticle formation was limited to liposomal and polymer based nanomaterial which is also called first generation nanoparticles [163]. The first liposomal based nanoformulation that made to the market was doxorubicin loaded liposomal nanoformulation called Doxil which showed better therapeutic effects than free doxorubicin [164-166]. Polymer based nanoformulation have also been studied [167, 168], for illustration, Poly(lactide-coglycolide) (PLGA) is an FDA-approved biodegradable and biocompatible polymer employed for controlled drug delivery applications including anti-cancer drug delivery [169-175]. Besides our research group, other investigators have also shown that using PLGA nanoparticles to deliver chemotherapeutic drugs results in significant improvement in inhibition of tumor burden in a wide variety of cancer models [176-181]. 


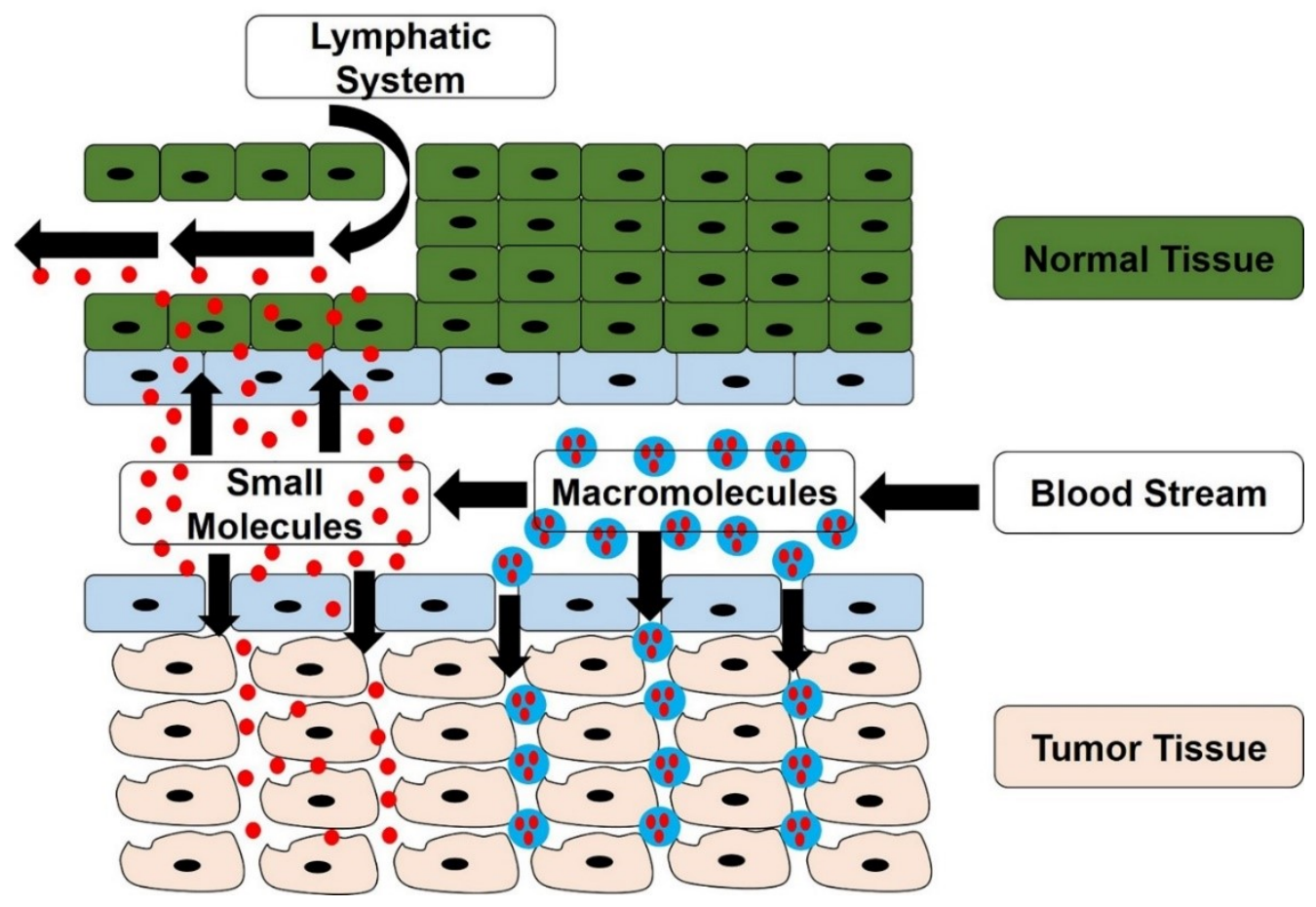

Figure 1-5. Diagram shows EPR (enhanced permeation and retention) effect. Modified with permission. Regehly, M., Photoinduced transfer processes in complex carrier systems for photodynamic therapy. 2008, Humboldt-Universität zu Berlin, Mathematisch-Naturwissenschaftliche Fakultät I. 


\title{
CHAPTER 2. EVALUATION OF ANTI-PROLIFERATIVE ACTIVITY OF ORMELOXIFENE IN CERVICAL CANCER CELLS
}

\author{
Materials and Methods
}

\section{Cell Culture}

All cells (Caski and SiHa (HPV positive), C33A and HT3 (HPV negative)) were obtained from ATCC. SiHa and C33A were cultured in DMEM medium supplemented with $4500 \mathrm{mg} / \mathrm{L}$ glucose, $4.00 \mathrm{mM}$ L- Glutamine, 10\% heat inactivated FBS (Atlantic Biologicals, Lawrenceville, G.A.), 1\% (5 ml) sodium pyruvate, 1\% (5ml) nonessential amino acids and 1\% (5 ml) $1 \times$ antibiotic/ antimycotic (Sigma, St. Louis MO). Caski cells were maintained in RPMI medium containing $2.05 \mathrm{mM} \mathrm{L}-$ Glutamine, $10 \%$ heat inactivated FBS and 1\% (5 ml) $1 \times$ antibiotic/antimycotic. HT3 cells were grown in McCoy's 5A medium accommodated with L- Glutamine, $10 \%$ heat inactivated FBS and $1 \%(5 \mathrm{ml})$ antibiotic/antimycotic. All cells were incubated at $37^{\circ} \mathrm{C}$ in a humidified atmosphere of $5 \% \mathrm{CO}_{2}$.

\section{Cell Proliferation Assays}

We utilized four different cervical cancer cell lines for proliferation measurements, Caski, SiHa, C33A and HT3 [129]. All cells were seeded at 5000 cells in $100 \mu \mathrm{L}$ media per well in 96-well plates and allowed to attach overnight. Following day, all 4 cervical cancer cell lines were treated with different micromolar concentrations (10 $\mu \mathrm{M}$ to $30 \mu \mathrm{M}$ ) of ormeloxifene (India). Ormeloxifene was dissolved in ETOH, diluted in tissue culture medium and then added to 96-well plates for 48 hours incubation. After 48 hours the CellTiter96 Aqueous One Solution (Promega, Madison, WI) was added to 96well plates $(20 \mu \mathrm{l} /$ well $)$, and the plates were incubated at $37^{\circ} \mathrm{C}$ for 2 hours and absorbency was measured at $490 \mathrm{~nm}$ using a spectrophometer. Three readings were obtained for each plate and proliferation results were normalized to control wells treated with vehicle control ETOH. The experiment was performed three individual times in duplicate each time.

\section{Colony Forming Assays}

All cervical cancer cells were seeded at 200 cells in $2 \mathrm{~mL} /$ well (Caski, SiHa and $\mathrm{C} 33 \mathrm{~A}$ ) and 500 cells in $2 \mathrm{~mL} /$ well (HT3) in 6 well plates and allowed to adhere overnight. The following day, fresh media containing different micromolar concentrations $(2.5 \mu \mathrm{M}$ to $10 \mu \mathrm{M})$ of ormeloxifene was added to the cells and cells were maintained for next 14 days. On the $14^{\text {th }}$ day cells were washed, fixed in cold methanol and stained with hematoxylin (Thermo Fisher). Visible colonies ( $\sim 50$ cells) were counted 
and presented as compared to the vehicle $(\mathrm{ETOH})$ control. Each experiment was done in duplicate and repeated 3 times.

\section{Real Time Cell Proliferation Kinetic Assay through xCELLigence System}

To determine the effect of ormeloxifene on real time cellular proliferation/growth, the xCELLigence system was used as described earlier [134]. xCELLigence system measures the cellular events (cell proliferation, migration and invasion) in real time as it is an electrical impedance-based method. In this experiment, plates (E plate VIEW 16, ACEA Biosciences) were pre-incubated with $30 \mu \mathrm{L}$ media for $30 \mathrm{~min}$ at $37^{\circ} \mathrm{C}$ and read for background measurement. Afterwards, both Caski and SiHa cells were plated at $8 \times$ $10^{3}$ /chamber in $100 \mu \mathrm{L}$ drug ( $20 \mu \mathrm{M}$ ormeloxifene) containing media for cell proliferation. Chamber plates were then incubated in xCELLigence instrument chamber/unit at $37^{\circ} \mathrm{C}$ with $5 \% \mathrm{CO}_{2}$ for real time cell proliferation. The experiment was performed two times.

\section{Statistical Methods}

Statistical analysis was determined by using an unpaired, two tailed student's ttest. The results were considered significant if $P<0.05$. All graphs were generated using GraphPad Prism5 software.

\section{Results}

\section{Ormeloxifene Treatment Inhibits Cellular Proliferation of Various Cervical Cancer Cells}

To determine the effect of Ormeloxifene on cell growth of various cervical cancer cells, we performed cell proliferation (MTS) assays with Caski and SiHa (HPV positive) and C33A and HT3 (HPV negative). Cells were treated with ormeloxifene at different micro-molar ranges for 48 hours. All four cells lines showed a significant decrease in a dose- dependent manner and a drastic inhibitory effect was found between $20 \mu \mathrm{m}$ and 30 $\mu \mathrm{m}$ doses (Figure 2-1, Figure 2-2, Figure 2-3 and Figure 2-4).

\section{Ormeloxifene Treatment Inhibits Clonogenic Potential of Various Cervical Cancer Cells}

Colony forming ability is an essential property of cancerous cells toward developing the tumor. Thus, we assessed colony forming assays to determine the long term effect of ormeloxifene on cervical cancer cells. Ormeloxifene showed a significant 


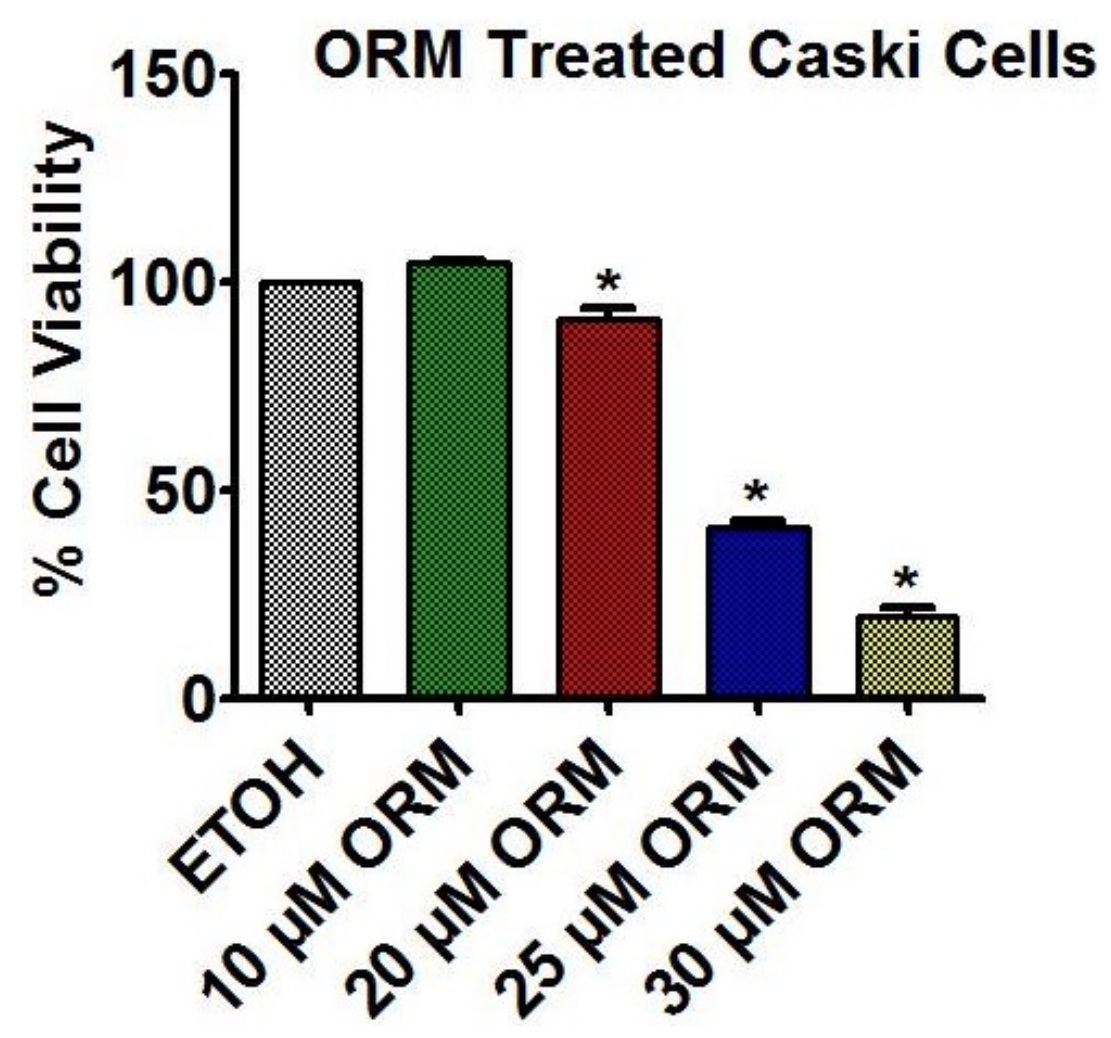

Figure 2-1. Ormeloxifene decreased cellular proliferation of Caski cells.

Cells were treated with ormeloxifene $(10,20,25$, and $30 \mu \mathrm{M})$ for $48 \mathrm{hrs}$ and MTS method was used to determine proliferation and absorbance was measured at $490 \mathrm{~nm}$. Results were normalized to the vehicle control (ETOH). Error bars show SEM, n=3. $* \mathrm{p}<0.05$. 


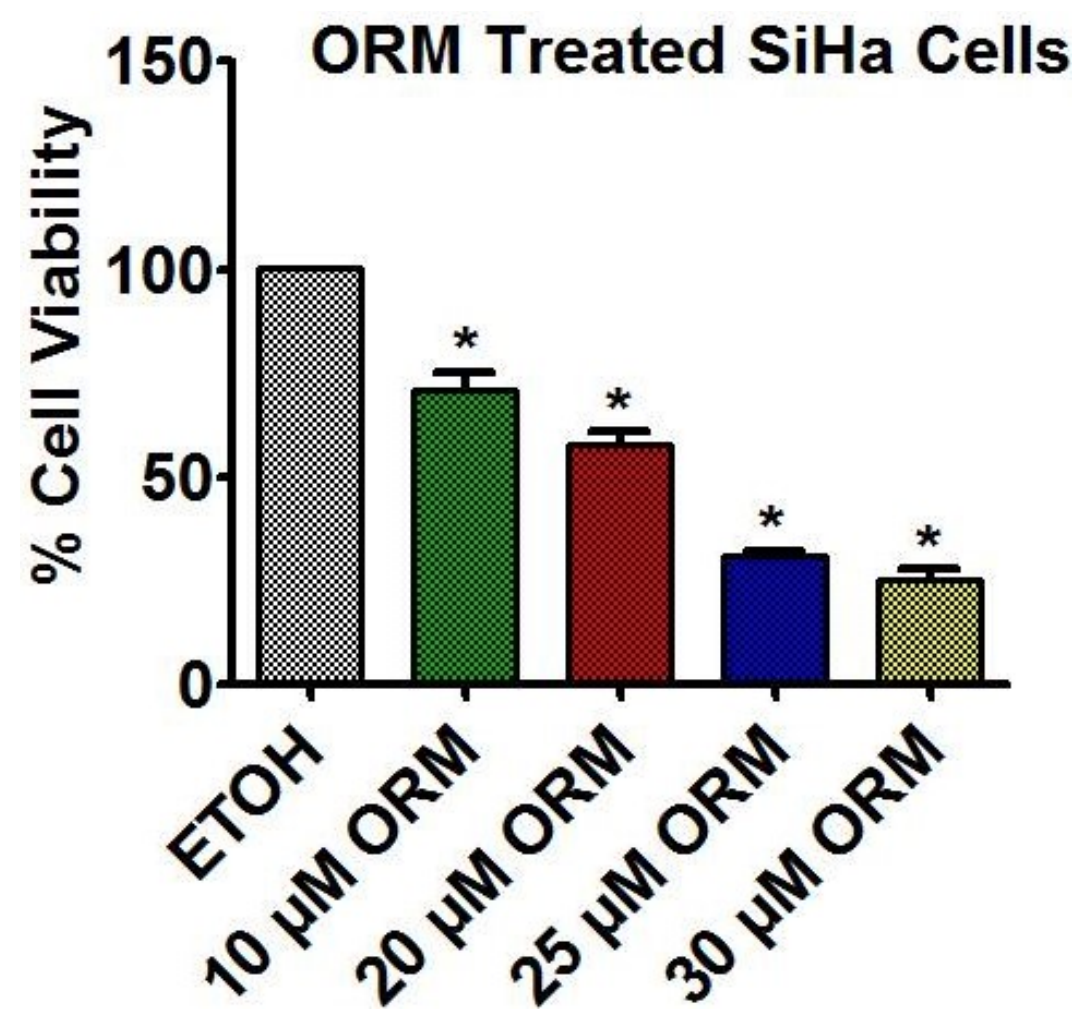

Figure 2-2. Ormeloxifene decreased cellular proliferation of SiHa cells.

Cells were treated with ormeloxifene $(10,20,25$, and $30 \mu \mathrm{M})$ for $48 \mathrm{hrs}$ and MTS method was used to determine proliferation and absorbance was measured at $490 \mathrm{~nm}$. Results were normalized to the vehicle control (ETOH). Error bars show SEM, n=3. ${ }^{*} \mathrm{p}<0.05$. 


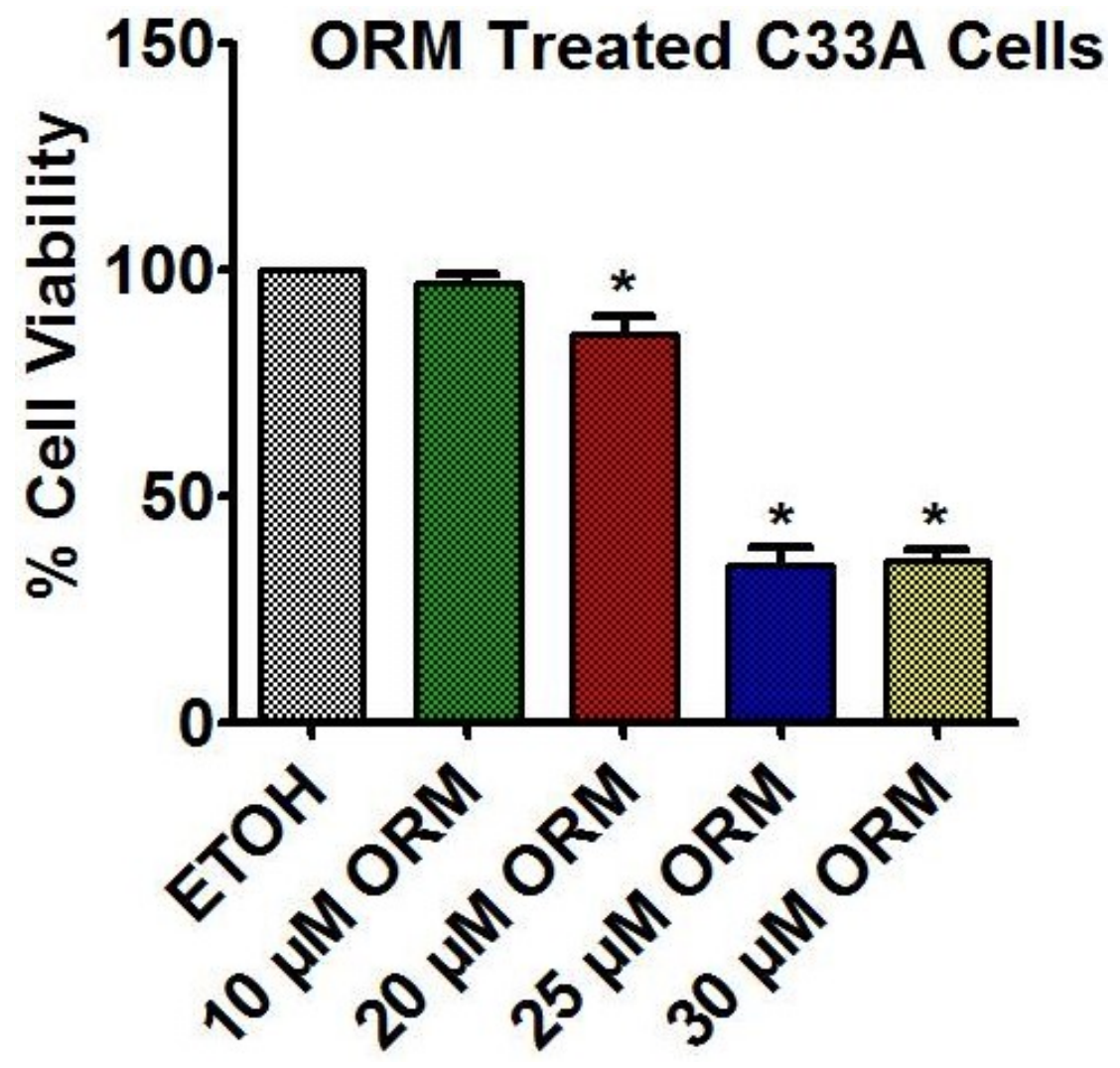

Figure 2-3. Ormeloxifene decreased cellular proliferation of C33A cells. Cells were treated with ormeloxifene $(10,20,25$, and $30 \mu \mathrm{M})$ for $48 \mathrm{hrs}$ and MTS method was used to determine proliferation and absorbance was measured at $490 \mathrm{~nm}$. Results were normalized to the vehicle control (ETOH). Error bars show SEM, n=3. $* \mathrm{p}<0.05$. 


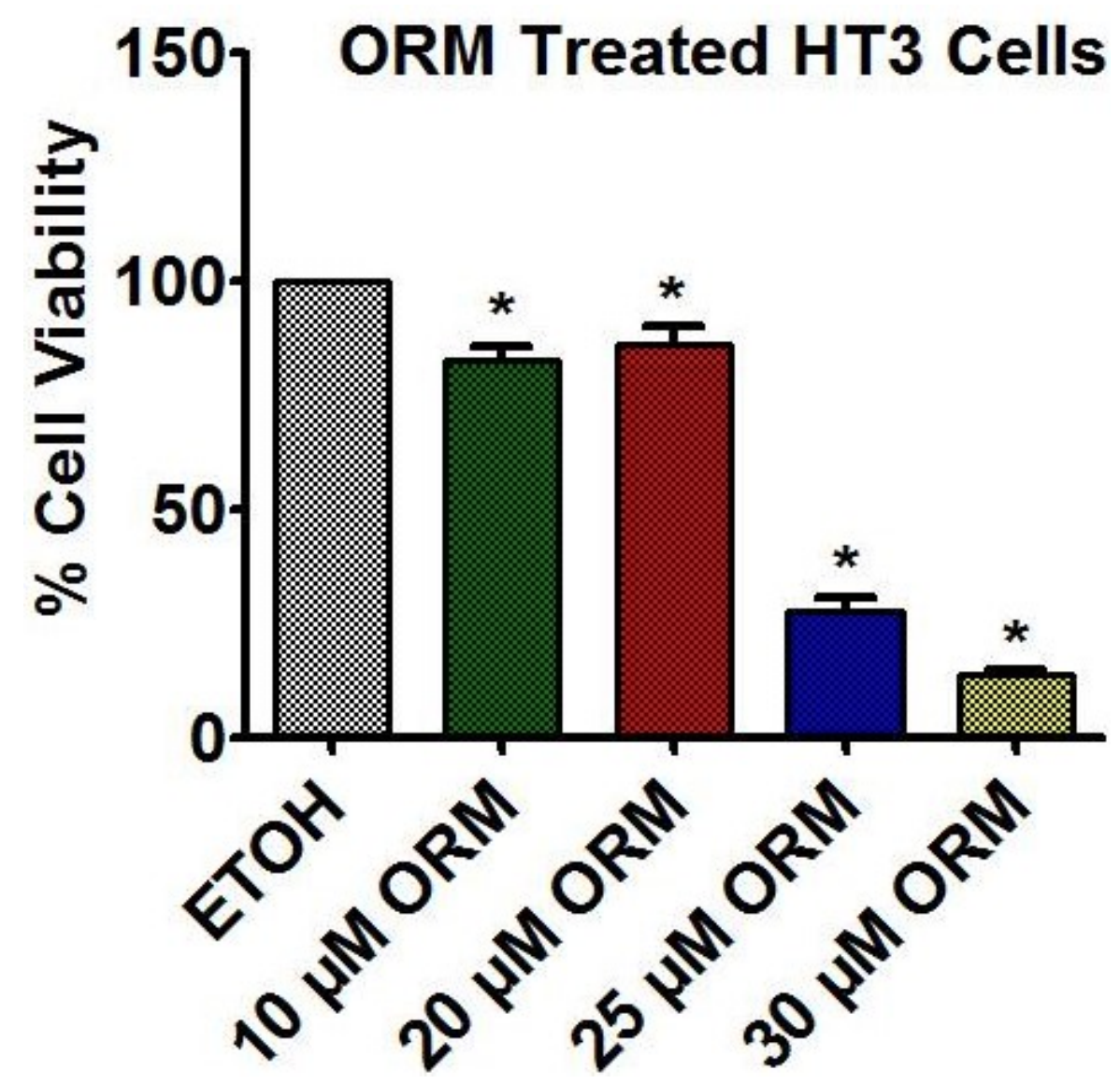

Figure 2-4. Ormeloxifene decreased cellular proliferation of HT3 cells.

Cells were treated with ormeloxifene $(10,20,25$, and $30 \mu \mathrm{M})$ for $48 \mathrm{hrs}$ and MTS method was used to determine proliferation and absorbance was measured at $490 \mathrm{~nm}$. Results were normalized to the vehicle control (ETOH). Error bars show SEM, $n=3$. $*_{p}<0.05$. 
effect on clonogenic potential of all tested cervical cancer cell lines in a dose dependent manner (Figure 2-5, Figure 2-6, Figure 2-7, Figure 2-8, Figure 2-9, Figure 2-10, Figure 2-11 and Figure 2-12).

\section{Real Time Growth Kinetics}

We performed a real time growth kinetic study using xCELLigence system to confirm ormeloxifene's effect on proliferation of Caski and SiHa cells. The study was conducted up to 160 hours and results were similar to MTS results. Ormeloxifene at 20 $\mathrm{mM}$ markedly decreased the cellular proliferation of both Caski and SiHa cells as compared to vehicle control ETOH (Figure 2-13 and Figure 2-14).
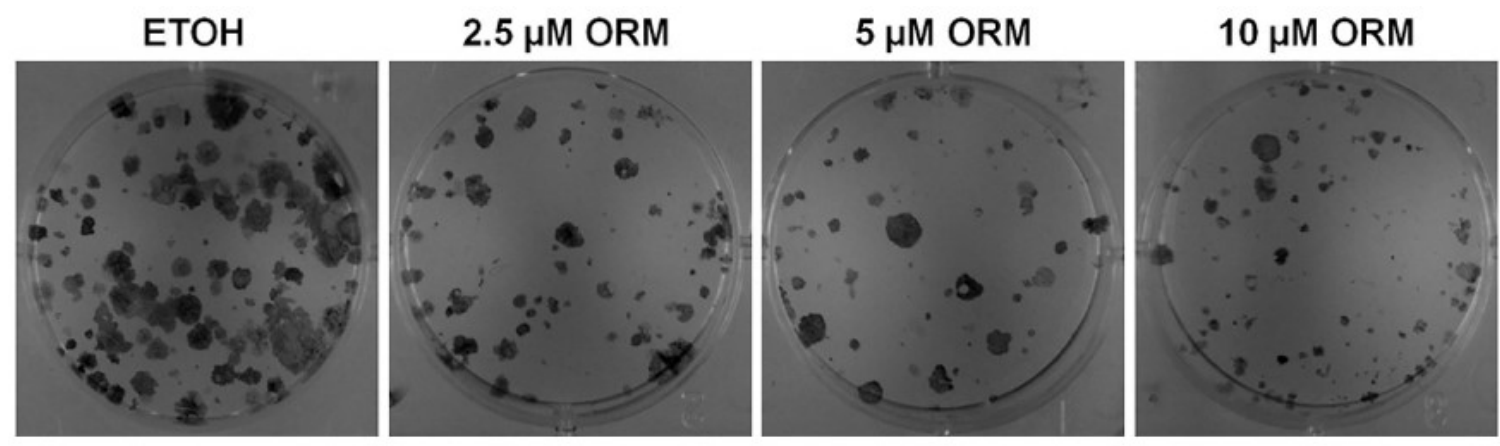

Figure 2-5. Ormeloxifene inhibited clonogenic potential of Caski cells.

Qualitative representation of inhibited clonogenecity of cells. Images were taken at 200X. 


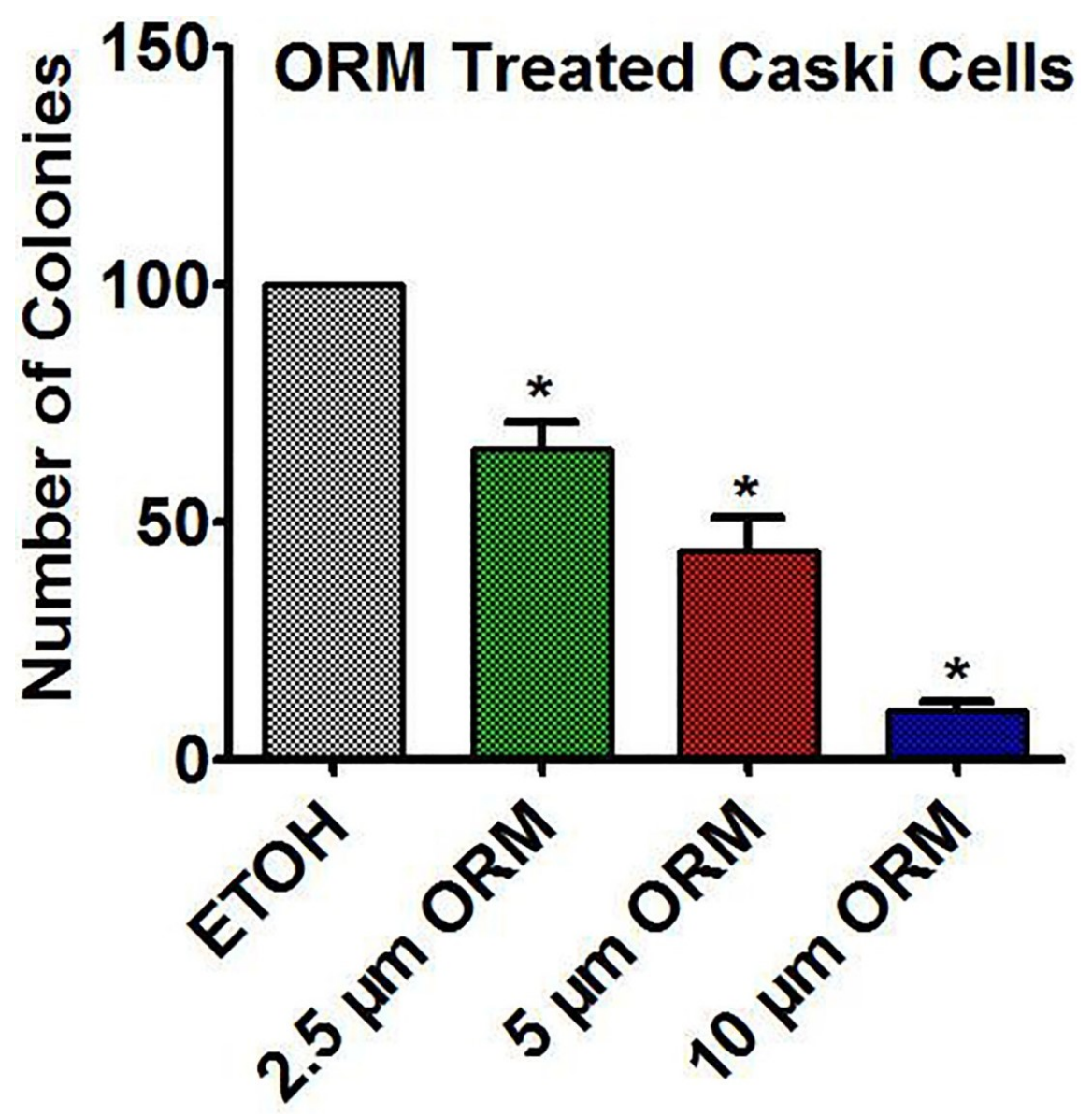

Figure 2-6. Bar graph showing that Ormeloxifene inhibited clonogenic potential of Caski cells.

Cells showed inhibited colony forming ability after 14 days of ormeloxifene treatment. Results were normalized to the ETOH control. Error bars show SEM, $n=3$. ${ }^{*} p<0.05$.
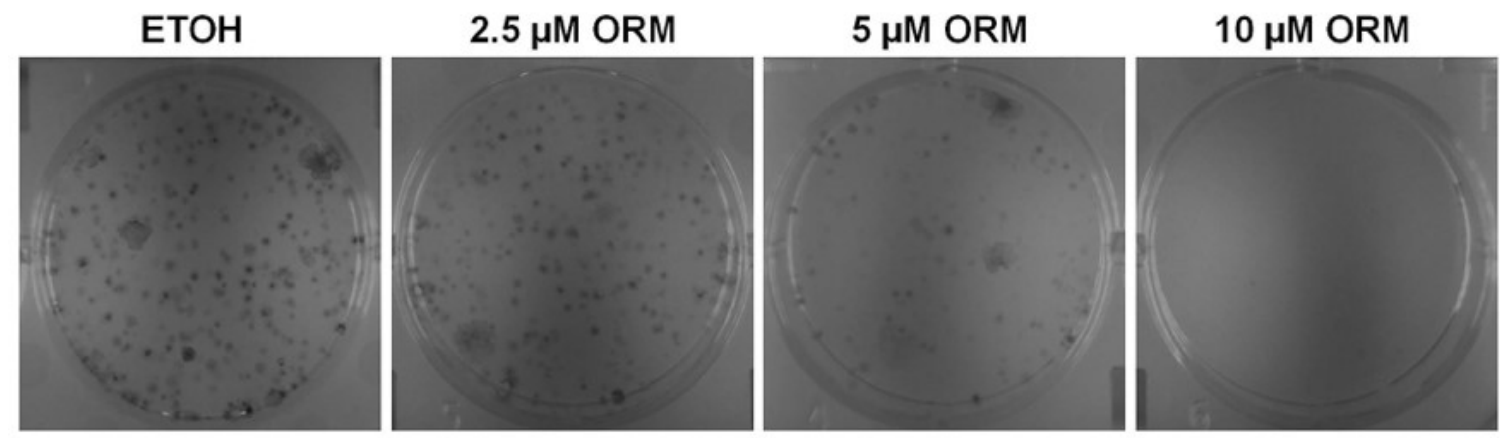

Figure 2-7. Ormeloxifene inhibited clonogenic potential of SiHa cells.

Qualitative representation of inhibited clonogenecity of cells. Images were taken at 200X. 


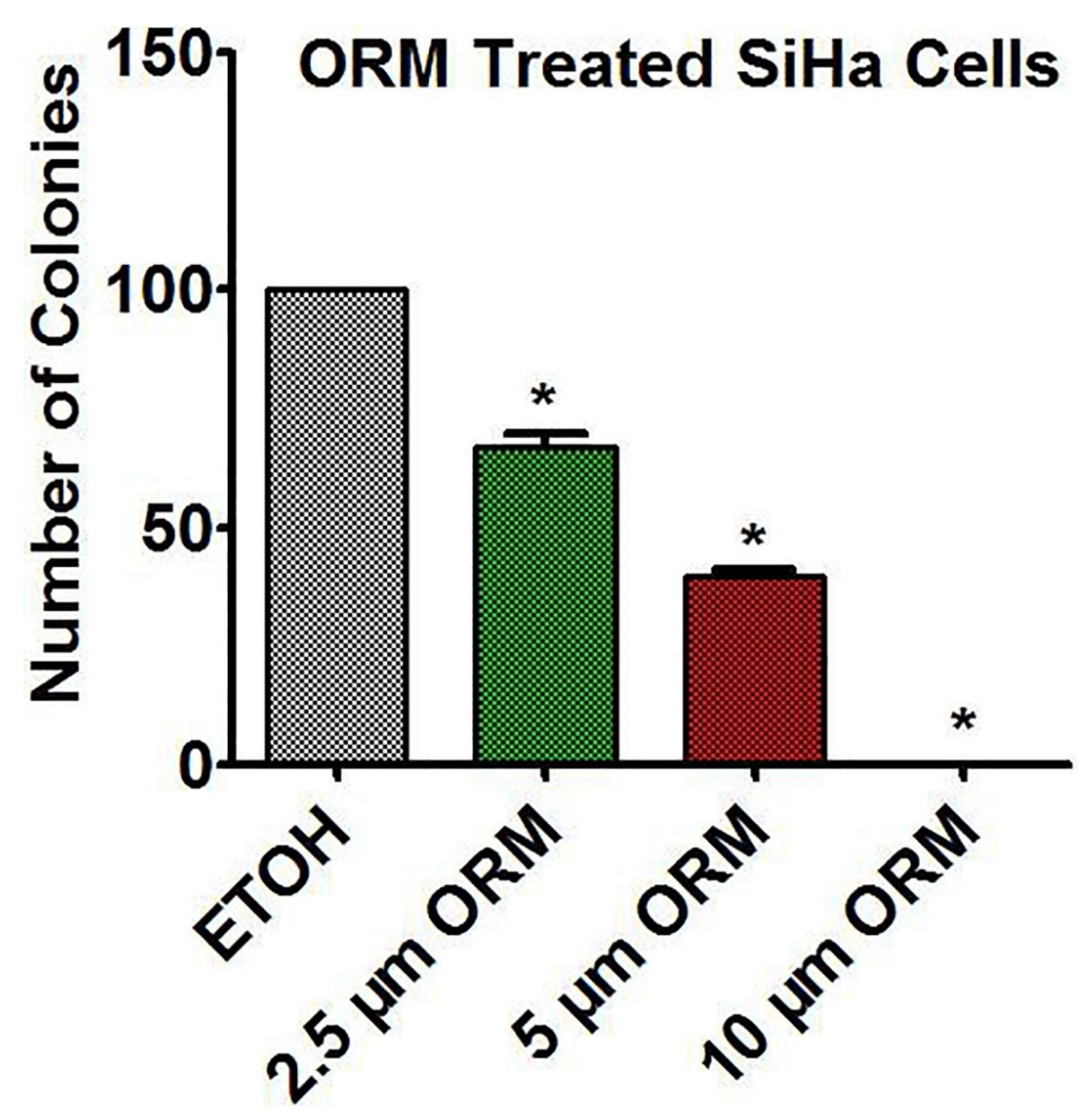

Figure 2-8. Bar graph showing that Ormeloxifene inhibited clonogenic potential of SiHa cells.

Cells showed inhibited colony forming ability after 14 days of ormeloxifene treatment. Results were normalized to the ETOH control. Error bars show SEM, $n=3 .{ }^{*} p<0.05$.
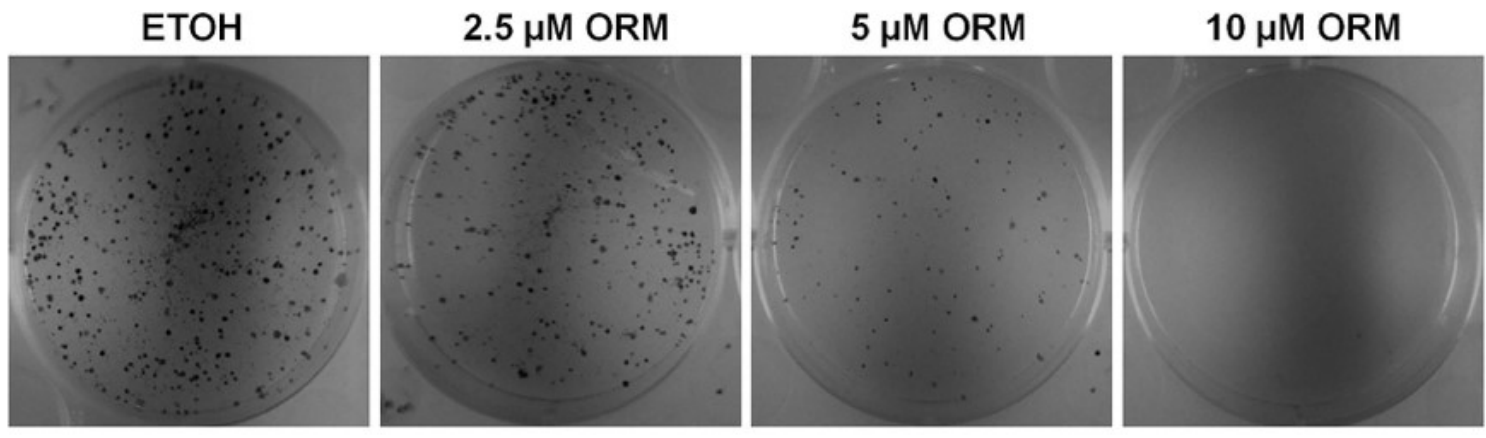

Figure 2-9. Ormeloxifene inhibited clonogenic potential of $\mathrm{C33A}$ cells.

Qualitative representation of inhibited clonogenecity of cells. Images were taken at 200X. 


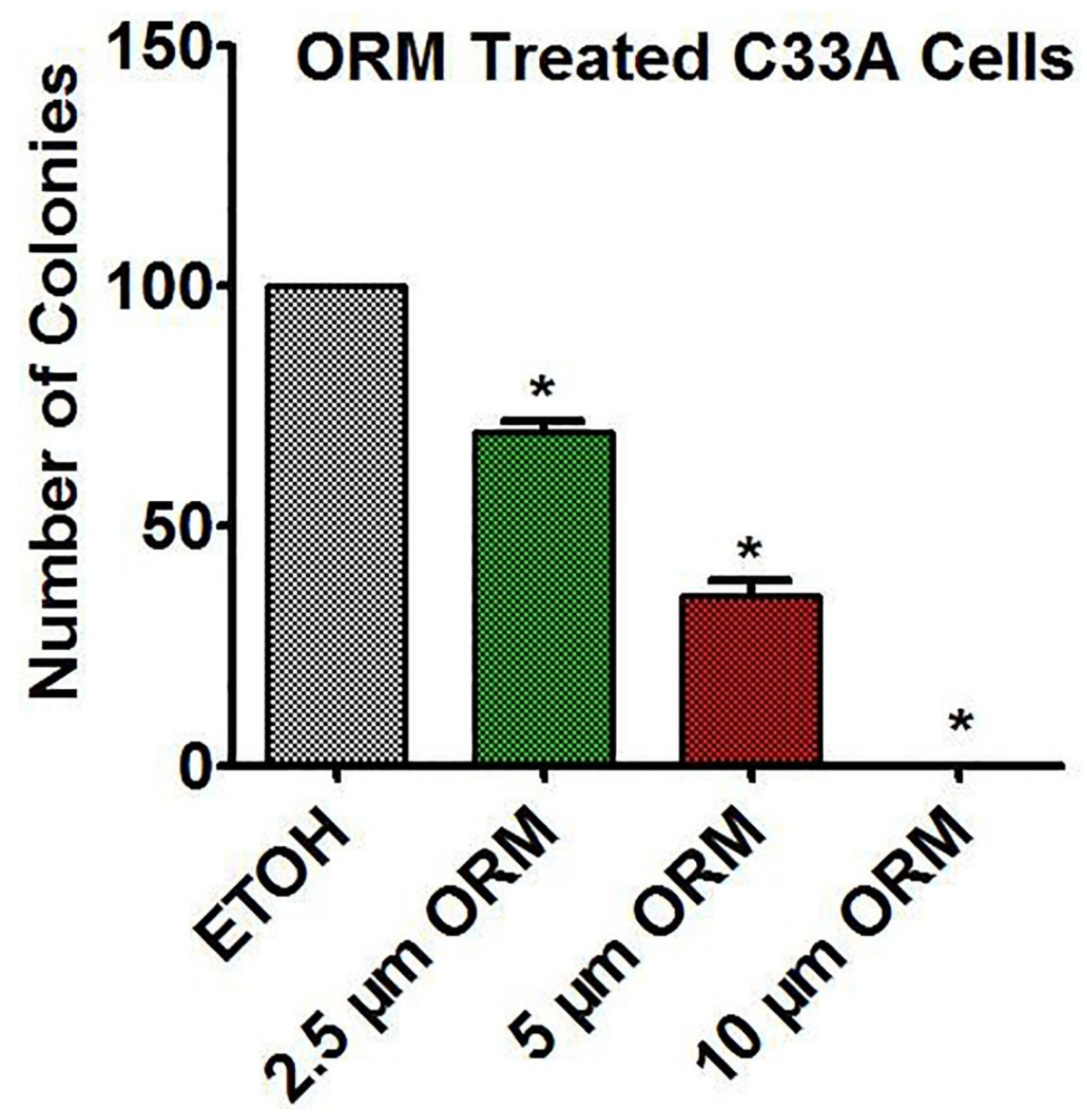

Figure 2-10. Bar graph showing that Ormeloxifene inhibited clonogenic potential of C33A cells.

Cells showed inhibited colony forming ability after 14 days of ormeloxifene treatment. Results were normalized to the ETOH control. Error bars show SEM, $n=3 .{ }^{*} p<0.05$.
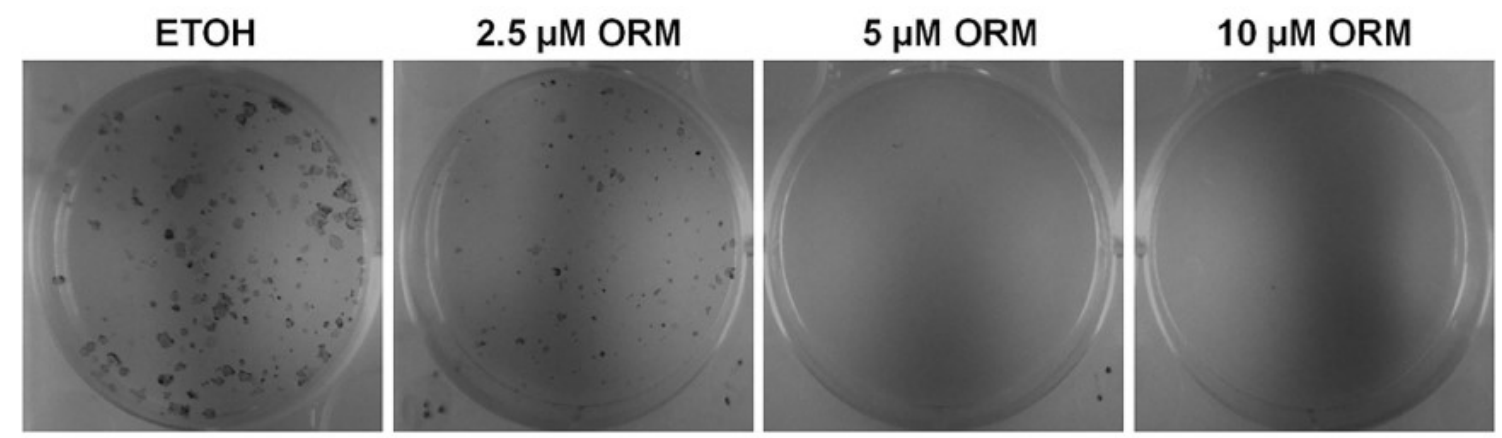

Figure 2-11. Ormeloxifene inhibited clonogenic potential of HT3 cells.

Qualitative representation of inhibited clonogenecity of cells. Images were taken at 200X. 


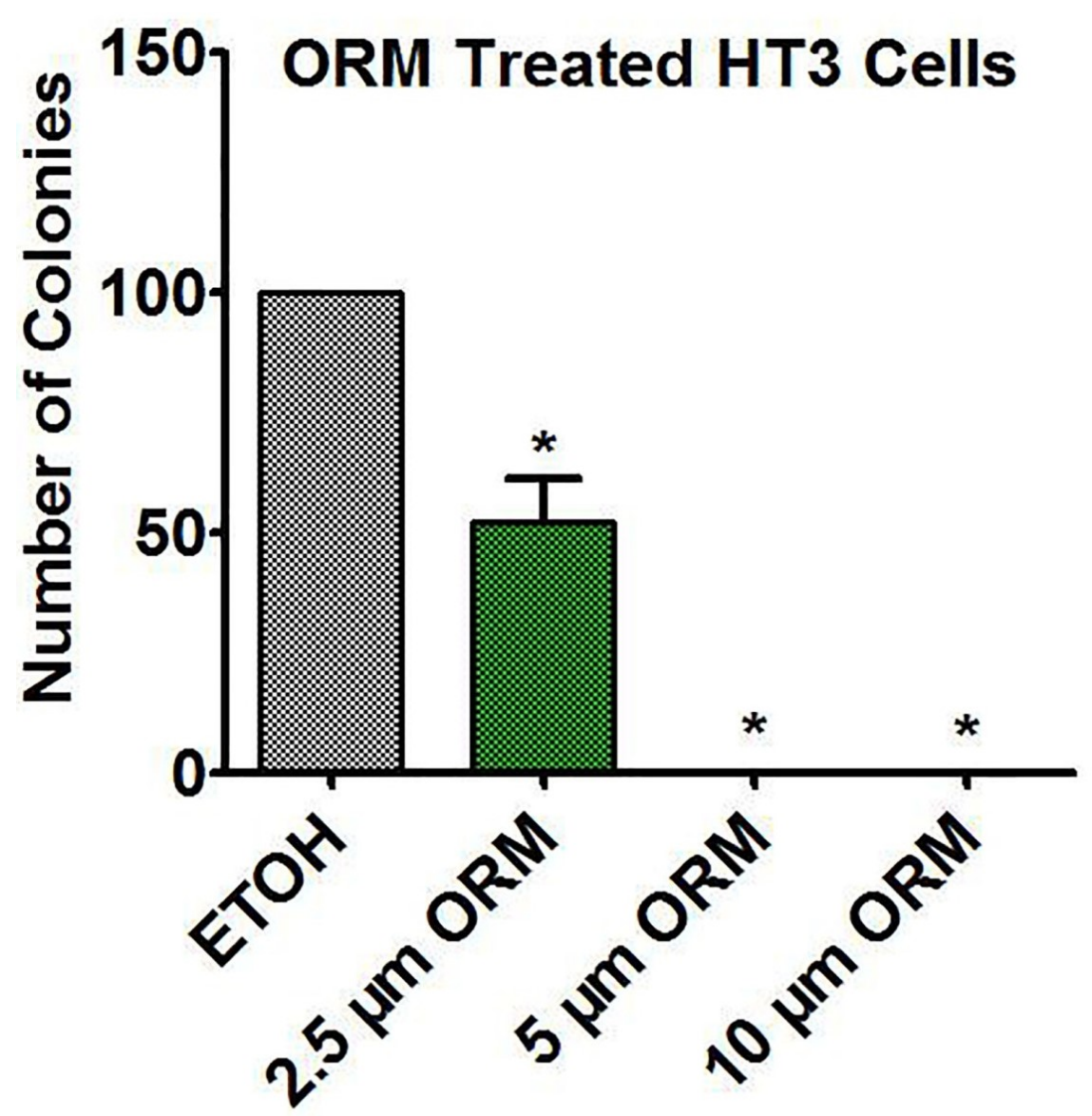

Figure 2-12. Bar graph showing that Ormeloxifene inhibited clonogenic potential of HT3 cells.

Cells showed inhibited colony forming ability after 14 days of ormeloxifene treatment. Results were normalized to the ETOH control. Error bars show SEM, $n=3 .{ }^{*} p<0.05$. 


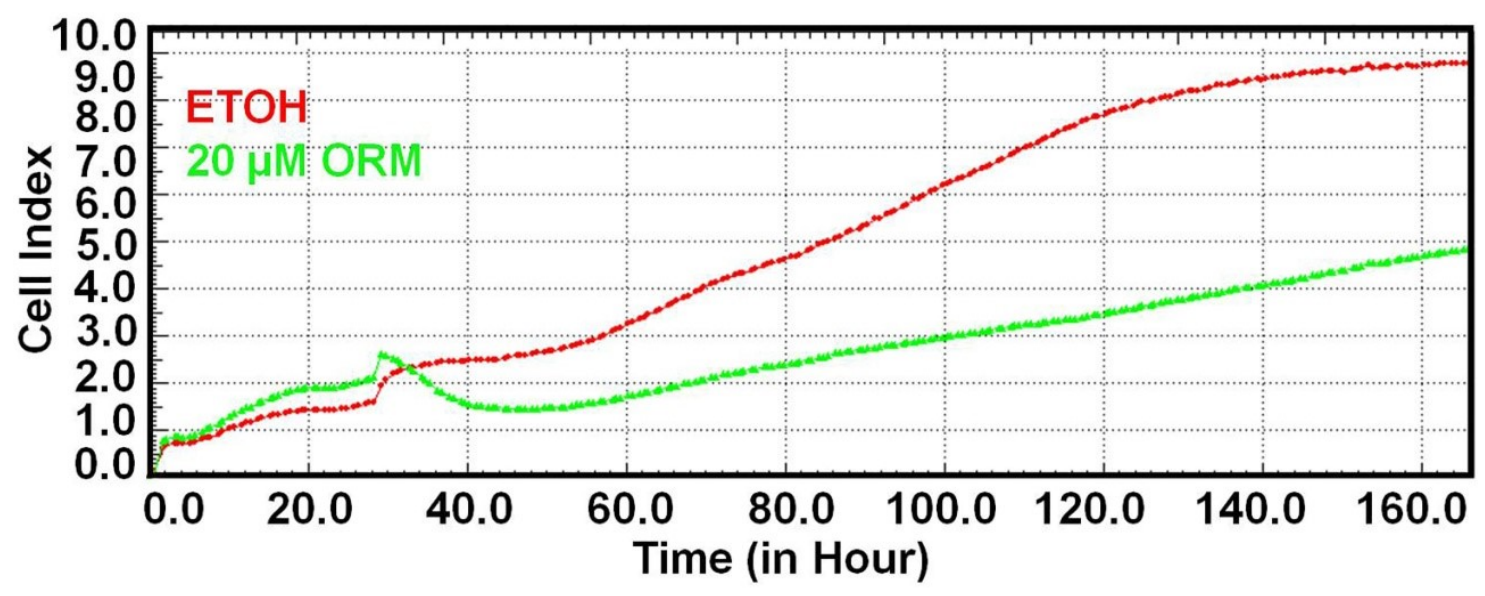

Figure 2-13. Ormeloxifene inhibited growth of Caski cells in real time. Cells were exposed to ormeloxifene treatment and measured for real time growth kinetics.

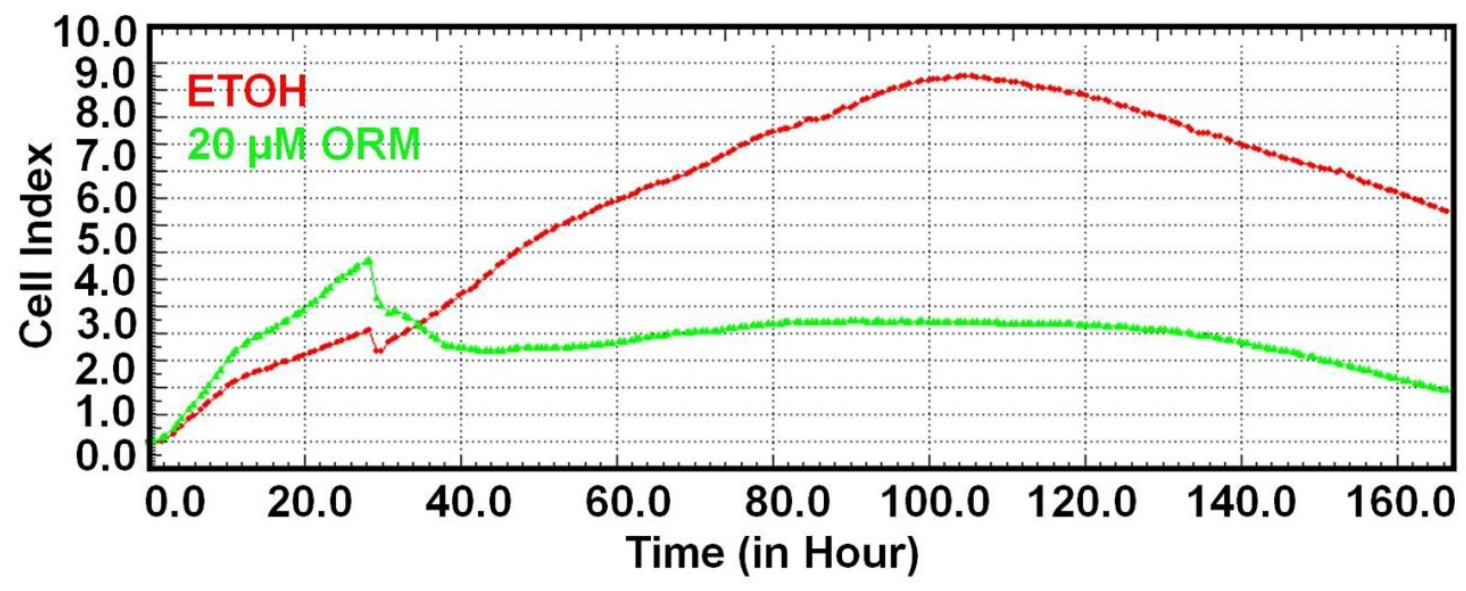

Figure 2-14. Ormeloxifene inhibited growth of $\mathrm{SiHa}$ cells in real time.

Cells were exposed to ormeloxifene treatment and measured for real time growth kinetics. 


\title{
CHAPTER 3. DETERMINATION OF ANTI-MOTILITY PROPERTITES OF ORMELOXIFENE IN CERVICAL CANCER CELLS
}

\author{
Materials and Methods
}

\section{Agarose Bead Assay}

To determine the effects of ormeloxifene on cellular motility of cervical cancer cells we performed agarose bead assay as performed previously in our lab [182]. For this experiment, 6-well plates were pre-coated with BSA-fibronectin. Cells (1X10 $)$ were trypsinized and mixed into a $0.2 \%$ low melting point agarose solution. About $30 \mu \mathrm{L}$ of cells/agarose suspension was then plated onto fibronectin/bovine serum albumin coated plates. The agarose-beaded plates were placed at $4^{\circ} \mathrm{C}$ for $10 \mathrm{~min}$ to set the agrose beads. Complete growth medium was slowly added from the edges of the wells so that beads were not disturbed and completely covered, and then plates were placed into a cell culture incubator at $37^{\circ} \mathrm{C}$ with $5 \% \mathrm{CO}_{2}$. At $0,12,24$ and $48 \mathrm{hrs}$ the plates were removed from the incubator and photographed under a phase-contrast microscope.

\section{Boyden Chamber Cell Migration Assay}

Cell migration assay was performed in a 96 well format HTS transwell plate from Corning. Both Caski and SiHa cells were serum starved for overnight and next day plated at 30,000 cells/well density in upper chambers containing $100 \mu \mathrm{L}$ serum free culture medium with different $(10,20$ and $25 \mu \mathrm{M})$ concentrations of ormeloxifene treatment and allowed to migrate towards FBS gradient to lower chamber with 10\% FBS for next 24 hours. At the end of indicated time cells were fixed with $4 \%$ paraformaldehyde prepared in PBS for $30 \mathrm{~min}$ at room temperature and stained with crystal violet for next $30 \mathrm{~min}$. Plates were then washed with running water to remove any excess staining. Cells in the upper chamber were completely removed by cotton swab while wet and plates were air dried overnight, next day, migrated cells were observed/ imaged by using light microscope at 100X magnification.

\section{Boyden Chamber Matrigel Cell Invasion Assay}

For invasion assay, we used BD Biocoat Matrigel Invasion Chambers 24 transwell format (BD Biosciences). Invasion chambers/inserts were rehydrated with 500 $\mu \mathrm{L}$ serum free culture medium for 2 hours at $37^{\circ} \mathrm{C}$. After 2 hours, 30,000 serum starved cells (cells were serum starved for overnight), in $500 \mu \mathrm{L}$ media, were plated in upper chamber/insert. The lower wells were also filled up with $500 \mu \mathrm{L}$ serum free media and chamber containing plates were incubated at $37^{\circ} \mathrm{C}$ for next 24 hours. Ormeloxifene treatment at 10, 20 and $25 \mu \mathrm{M}$ concentrations in $500 \mu \mathrm{L}$ serum free media was given to the upper chambers next morning and serum free media in lower wells was replaced with 
$10 \%$ FBS containing media. Cells were now allowed to invade across the matrigel towards FBS gradient in the lower chamber for next 24 hours. At the end of given time point, cells were fixed with $4 \%$ paraformaldehyde for $30 \mathrm{~min}$ at room temperature, stained with crystal violet for another $30 \mathrm{~min}$, washed with running water, and air dried. Cells at the bottom side of chamber/insert (invaded cells) were imaged at 100X magnification by using a light microscope.

\section{Real Time Migration and Invasion Assays through xCELLigence System}

The xCELLigence system was used for real time migration assessment of Caski and SiHa cells. 16 chamber plates (CIM plate 16, ACEA Biosciences) were utilized for this assay and the upper chambers were pre-incubated with $30 \mu \mathrm{L}$ serum free media for $30 \mathrm{~min}$ at $37^{\circ} \mathrm{C}$ and the background reading was recorded. Next, Caski and SiHa cells were plated at $3 \times 10^{4}$ per chamber with ormeloxifene $(10,20$ and $25 \mu \mathrm{M})$ and its vehicle control ETOH treatments in $100 \mu \mathrm{L}$ serum free media. The bottom wells were provided with $160 \mu \mathrm{L}$ of $10 \%$ FBS media. Cells were allowed to settle for $30 \mathrm{~min}$ at room temperature before plates were incubated in xCELLigence instrument chamber/unit at $37^{\circ} \mathrm{C}$ with $5 \% \mathrm{CO}_{2}$. In invasion assay before pre-incubation, the upper chambers were coated with $800 \mu \mathrm{g} / \mathrm{mL}$ matrigel $(80 \mu \mathrm{L}$ matrigel $+1920 \mu \mathrm{L}$ serum free media) for 4 hours at $37^{\circ} \mathrm{C}$. Each experiment was done twice.

\section{Statistical Methods}

All graphs were generated using GraphPad Prism5 software.

\section{Results}

Ormeloxifene inhibited cellular migration and invasion of cervical cancer cells. In order to analyze the metastatic properties of cervical cancer cells after ormeloxifene treatment, we performed agarose bead assay (Figure 3-1 and Figure 3-2), cell migration (Figure 3-3 and Figure 3-4) and invasion assays (Figure 3-5 and Figure 3-6) using Boyden chamber migration and Boyden chamber matrigel invasion assay. Both Caski and $\mathrm{SiHa}$ cells showed an inhibition of motility/migration and invasion with an increase in ormeloxifene concentration. A real time kinetic assessment for migration (Figure 3-7 and Figure 3-8) and invasion (Figure 3-9 and Figure 3-10) was also performed using xCELLigence system to confirm ormeloxifene's effect on metastasis of Caski and $\mathrm{SiHa}$ cells, and results were consistence with Boyden chamber assay. Furthermore, migratory ability of cells was analyzed by using agarose bead and wound healing assays. Ormeloxifene treatment again showed an inhibition of migration in dose and time dependent manner in both cells. 


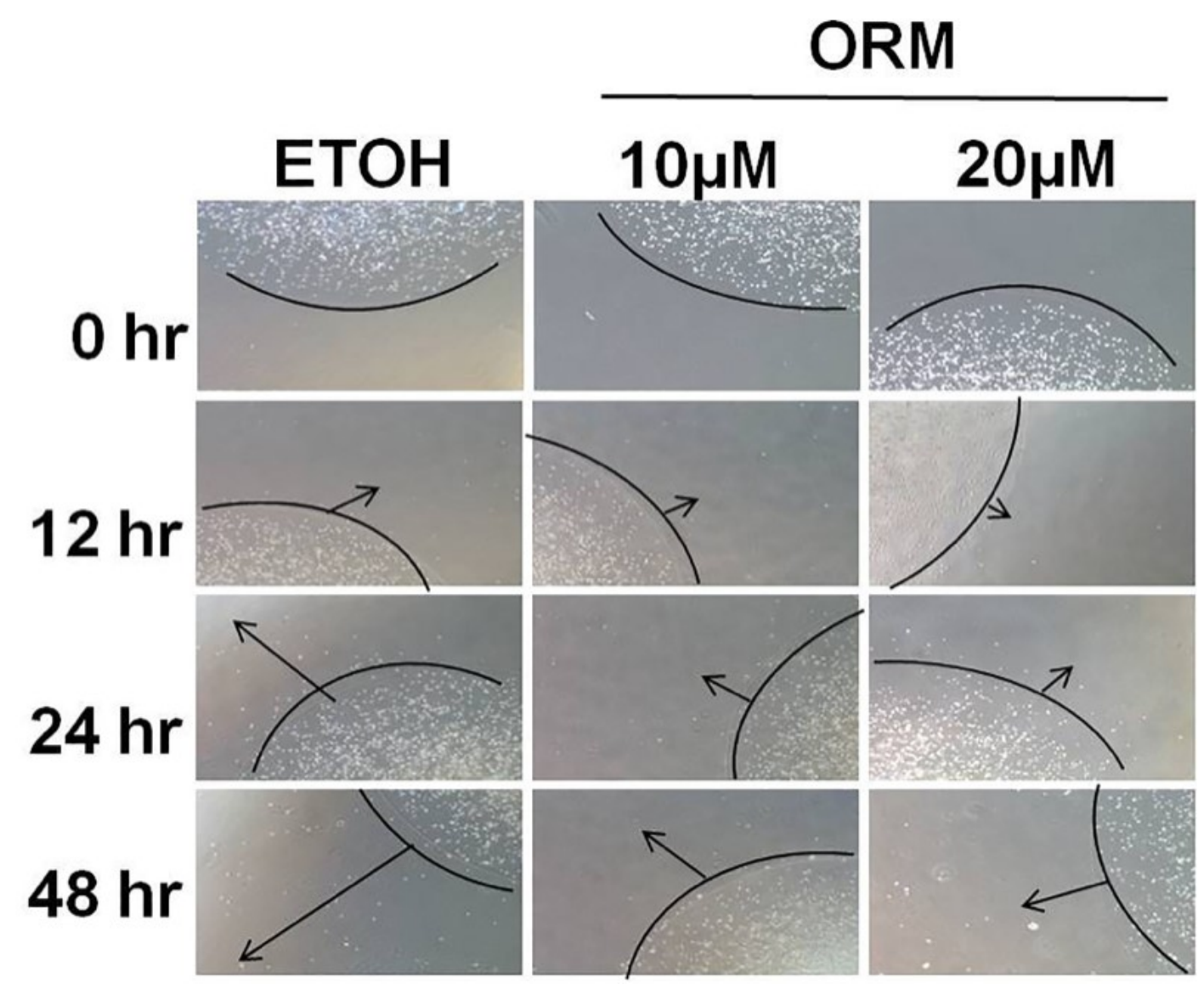

Figure 3-1. Ormeloxifene decreased cellular motility of Caski cells confirmed through agarose bead assay.

Cells were treated with ormeloxifene up to 48 hours and images were taken at 100X. 


\section{ORM}

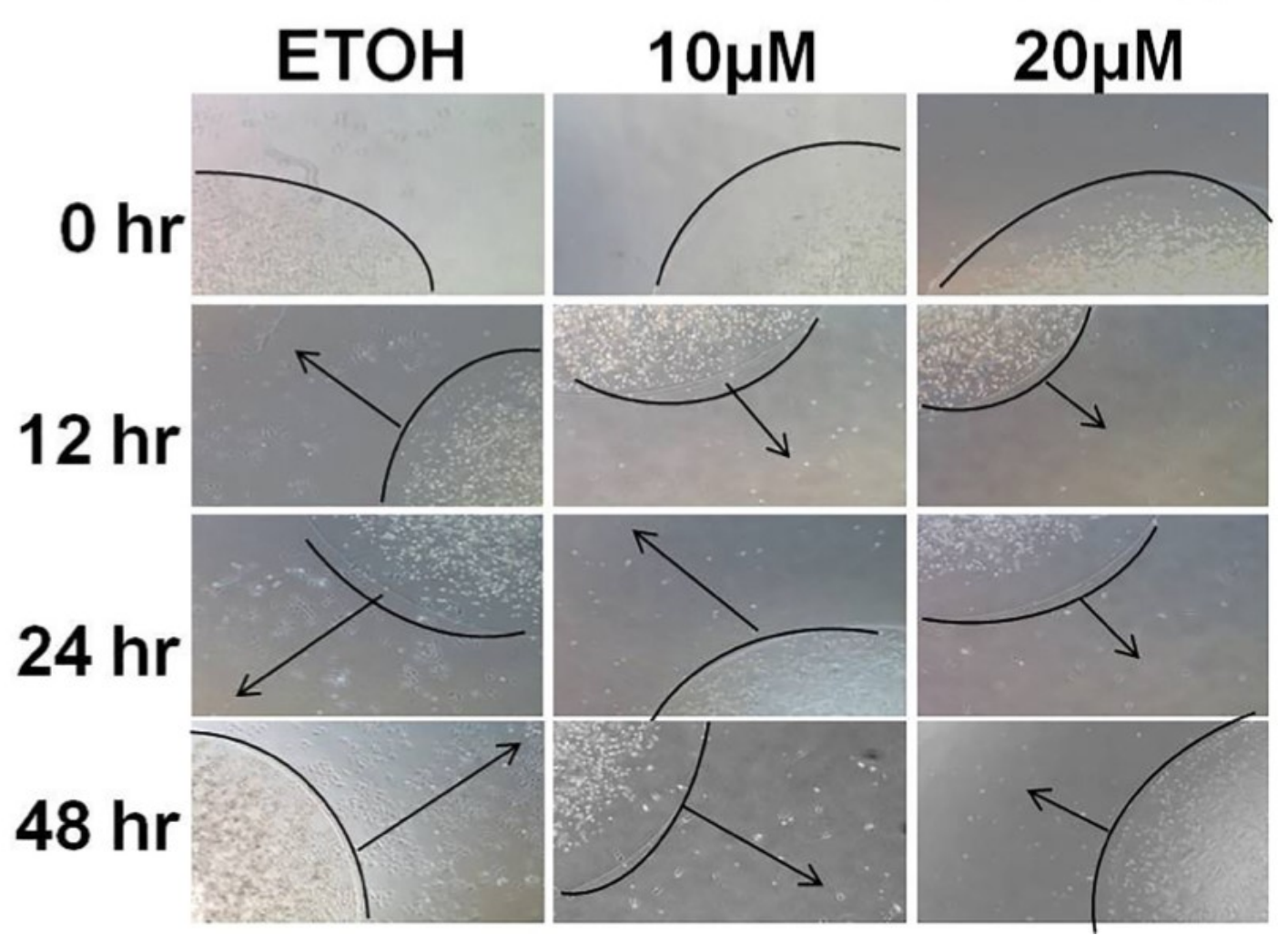

Figure 3-2. Ormeloxifene decreased cellular motility of SiHa cells confirmed through agarose bead assay.

Cells were treated with ormeloxifene up to 48 hours and images were taken at 100X.
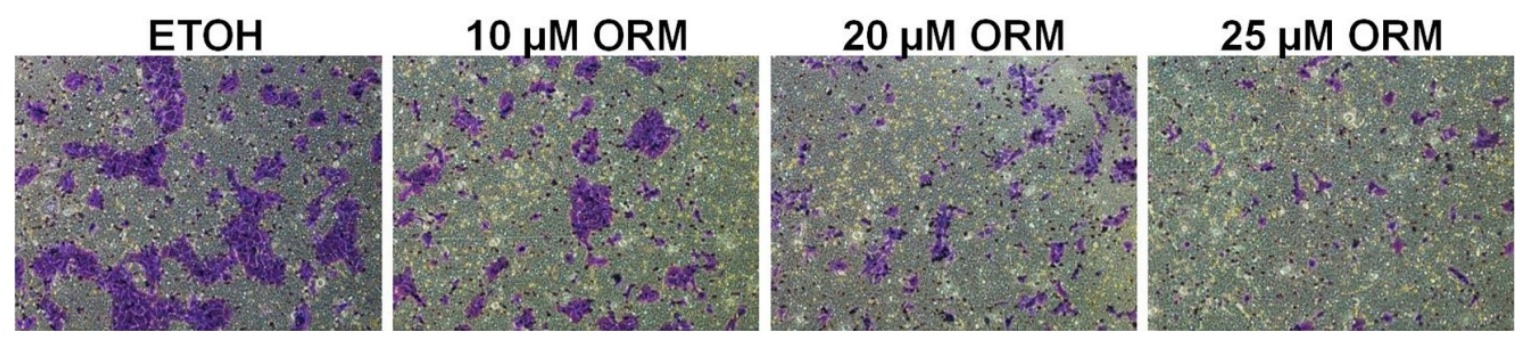

Figure 3-3. Ormeloxifene decreased cellular migration of Caski cells confirmed through Boyden chamber migration assay.

Cells were treated with ormeloxifene for 24 hours and images were taken at 100X. 

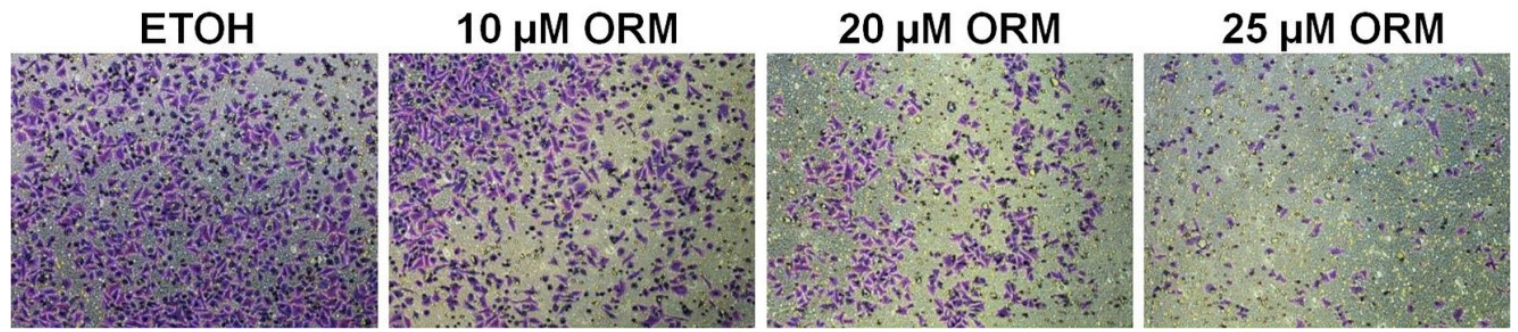

Figure 3-4. Ormeloxifene decreased cellular migration of SiHa cells confirmed through Boyden chamber migration assay.

Cells were treated with ormeloxifene for 24 hours and images were taken at 100X.
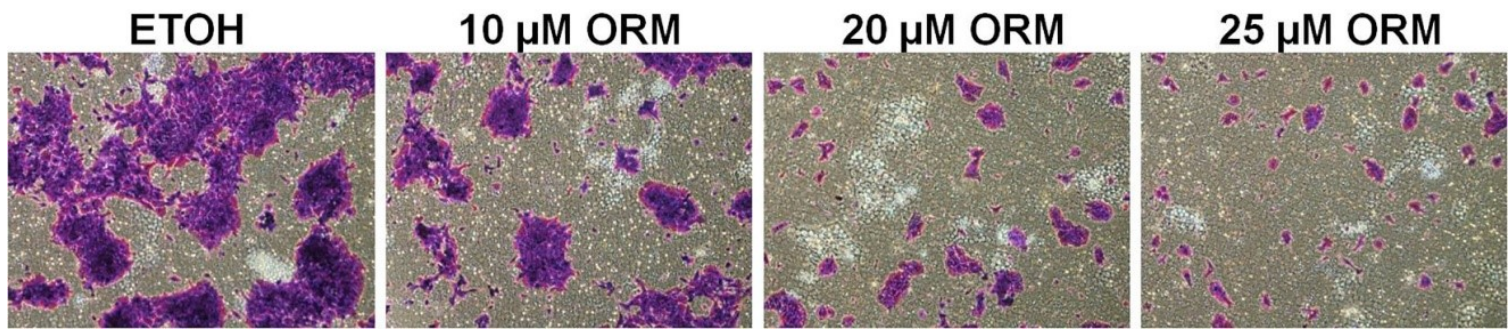

Figure 3-5. Ormeloxifene decreased cellular invasion of Caski cells confirmed through Boyden chamber matrigel invasion assay.

Cells were treated with ormeloxifene for 24 hours and images were taken at 100X.
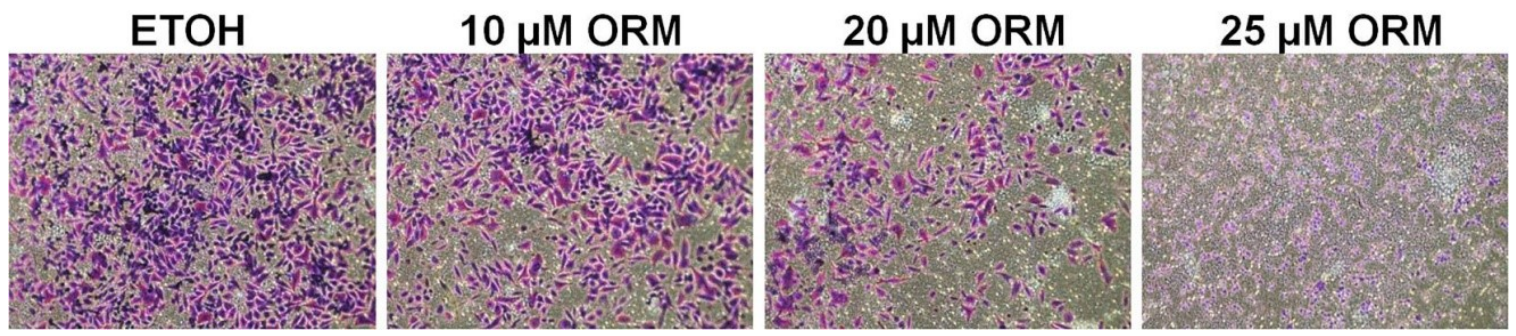

Figure 3-6. Ormeloxifene decreased cellular invasion of SiHa cells confirmed through Boyden chamber matrigel invasion assay.

Cells were treated with ormeloxifene for 24 hours and images were taken at 100X. 


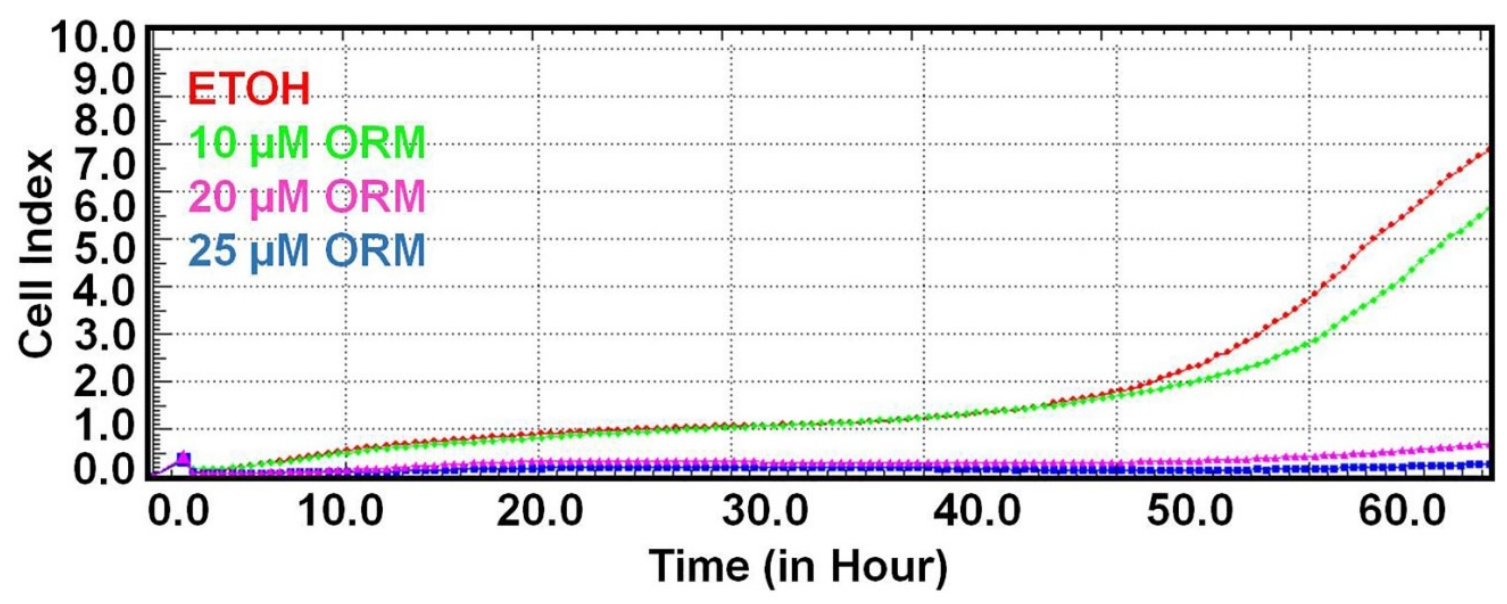

Figure 3-7. Ormeloxifene inhibited migration of Caski cells in real time. Cells were exposed to ormeloxifene treatment and measured for real time migration kinetics.

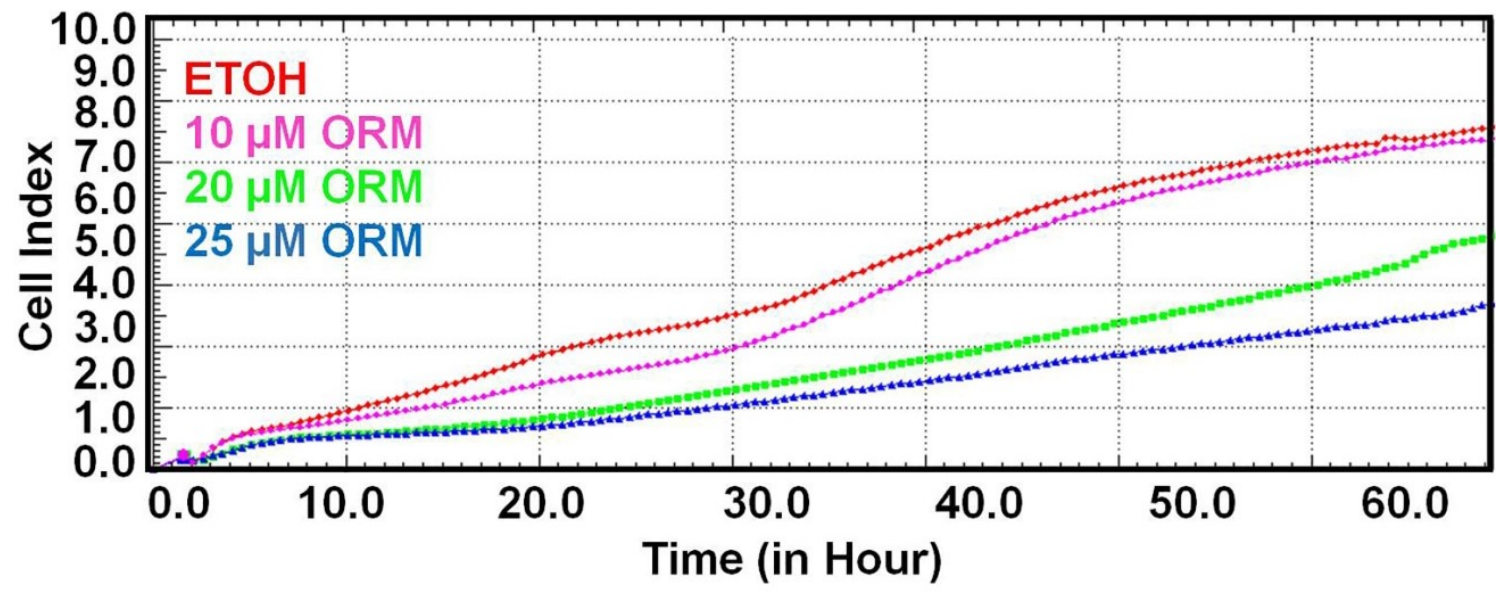

Figure 3-8. Ormeloxifene inhibited migration of SiHa cells in real time.

Cells were exposed to ormeloxifene treatment and measured for real time migration kinetics. 


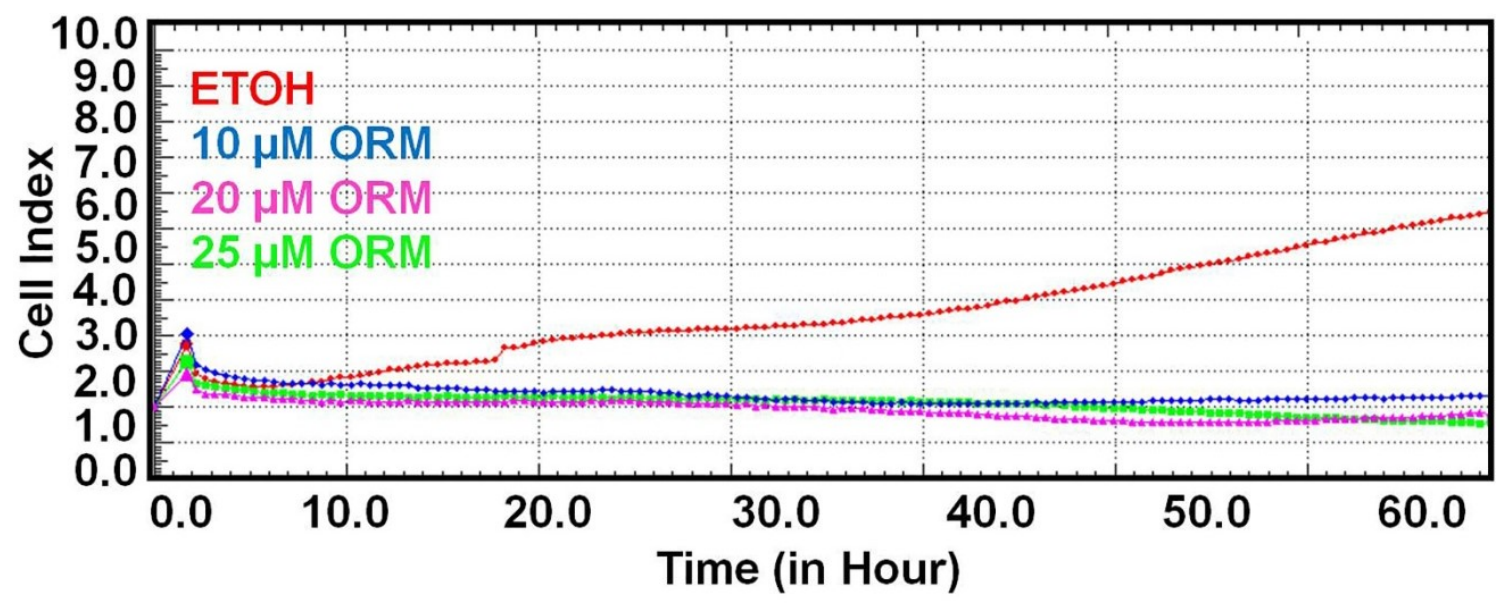

Figure 3-9. Ormeloxifene inhibited invasion of Caski cells in real time. Cells were exposed to ormeloxifene treatment and measured for real time invasion kinetics.

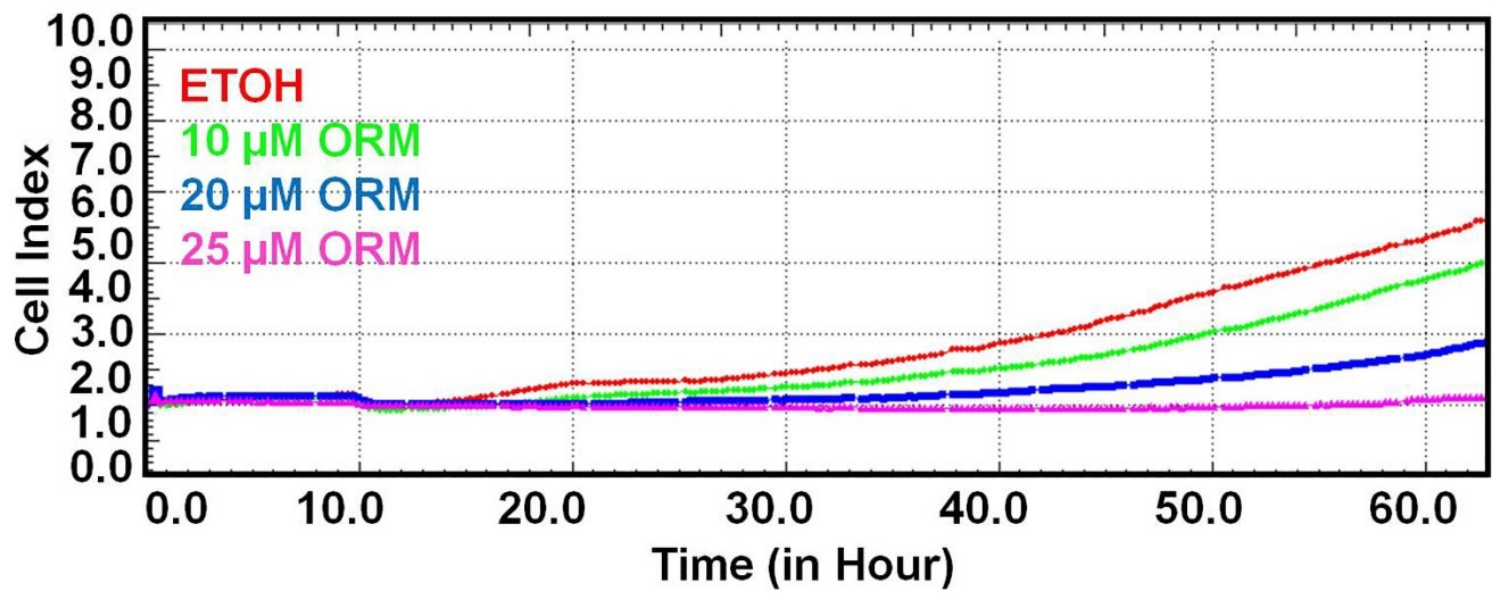

Figure 3-10. Ormeloxifene inhibited invasion of SiHa cells in real time. Cells were exposed to ormeloxifene treatment and measured for real time invasion kinetics. 


\title{
CHAPTER 4. ASSESSMENT OF APOPTOSIS INDUCING ABILITY OF ORMELOXIFENE IN CERVICAL CANCER CELLS
}

\author{
Materials and Methods
}

\section{Morphology Visualization with Phase Contrast Microscopy}

Both cervical cancer cell lines were plated at $1 \times 10^{6}$ per $100 \mathrm{~mm}$ dish and allowed to adhere for overnight. Next day, cells were treated with a range of ormeloxifene concentrations (10, 20 and $25 \mu \mathrm{m})$ for 24 hours. At the end point cells were washed with PBS and images were taken by using phase contrast microscopy at $200 \mathrm{X}$.

\section{Mitochondrial Membrane Potential}

Reduction in mitochondrial membrane potential is the first and an important event of intrinsic mitochondrial apoptotic cascade [183, 184]. Tetramethyl rhodamine ethyl ester (TMRE) (Invitrogen) is an orange colored, positively charged dye that premeabilizes through the mitochondrial membrane and sequesters into the healthy and active mitochondria; thus, it is a widely used marker for mitochondrial membrane potential [185]. Caski and SiHa cervical cancer cells at 1 X10 $\%$ plate were plated, allowed to attach overnight and exposed to ormeloxifene treatment for 24 hours. At the indicated time, cells were washed with PBS, incubated with $2 \mathrm{~mL}$ phenol red free medium containing $50 \mathrm{nM}$ TMRE at $37^{\circ} \mathrm{C}$ for 20 minutes, washed twice with PBS and supplied with phenol red free medium and imaged using an Olympus microscope for the qualitative assessment at 200X. After imaging, cells were washed with PBS, trypsinized and analyzed with Accuri C6 flow cytometer in FL2 channel for the quantitative measurement.

\section{Cell Cycle Analysis}

Telford method is a widely used method to detect different phases of cell cycle [186]. Caski and SiHa cells were plated in $100 \mathrm{~mm}$ dish at the density of 1 X10 $/$ plate and allowed to adhere overnight. Next day, cells were exposed to ormeloxifene treatment at 10 and $20 \mu \mathrm{M}$ concentration for 24 hours. After 24 hours, cells were trypsinized, washed twice with PBS, fixed with $70 \%$ ice cold ETOH and saved at $-20^{\circ} \mathrm{C}$ until further used. Cells were stained with Propidium Iodide solution (Sigma-Aldrich, St. Louis, MO) $50 \mu \mathrm{g}$ in $1 \mathrm{~mL}$ Telford reagent at $1 \mathrm{~mL}$ for $1 \times 10^{6}$ cells for 4 hours at $4^{\circ} \mathrm{C}$ in the dark and analyzed by Accuri C6 (BD Biosciences) flow cytometer in FL2 channel of red fluorescence. 


\section{Annexin V- 7AAD Staining}

Annexin V labels the early apoptotic cells by binding to phosphatidylserine which becomes exposed at the outside of the cell membrane as cells undergo apoptosis; thus, it is a marker of early apoptosis [187] where as 7AAD is a marker of dead cells [188]. To assess the induction of apoptosis, Caski and SiHa cervical cancer cells were plated $\left(1 \times 10^{6} /\right.$ plate) and allowed to attach overnight. Next morning, cells were treated with different concentrations of ormeloxifene for 24 hours; both floaters and adherent cells were collected, washed twice with PBS and stained with Annexin V and 7AAD (BD Biosciences, San Diego, CA), $5 \mu \mathrm{L}$ of each/100 $\mu \mathrm{L}$ of cell suspension for $20 \mathrm{~min}$ in the dark at room temperature. After the incubation, cells were analyzed with Accuri C6 flow cytometer in FL2 channel.

\section{Reactive Oxygen Species (ROS)}

Both Caski and SiHa cervical cancer cells were plated at $1 \mathrm{X} 10^{6} / 100 \mathrm{~mm}$ dish and allowed to adhere overnight. Next morning, cells were exposed to $25 \mu \mathrm{M}$ concentration of ormeloxifene for 24 hours. After 24 hours cell were washed with PBS, trypsinized and centrifuged at $1000 \mathrm{RPM}$ for $5 \mathrm{~min}$. The final cell pellet was resuspended in $1 \mathrm{~mL}$ of PBS containing $20 \mu \mathrm{M}$ DCFH-DA stain (a dye that is widely used to detect generation of ROS [189]) and cells were then incubated for 20 minutes at $37^{\circ} \mathrm{C}$. After 20 min cells were analyzed with Accuri C6 flow cytometer (BD Biosciences) in FL2 channel for the measurement of reactive oxygen species generation.

\section{Immunoblotting}

Caski and $\mathrm{SiHa}\left(1 \mathrm{X} 10^{6}\right)$ cells were plated per $100 \mathrm{~mm}$ dish and allowed to attach overnight. Next day cells were treated with different micromolar concentrations of ormeloxifene for 24 hours. After treatment, both adherent and floating cells were collected in 2x SDS lysis buffer (Santa Cruz Biotechnologies, Santa Cruz, CA), sonicated and the protein concentration was normalized using SYPRO- Orange (Molecular Probes). SDS - PAGE electrophoresis was done using 10\% gradient gel and resolved proteins were transferred onto PVDF (BioRad, Hercules, CA) membrane. HPV 16 E6/E7 (Abcam), PI3K, Akt, pAkt, Rb, PTPN13, Cyclin E and Cdk2 (Cell Signaling) and p53 (Santa Cruz) primary antibodies were used. The primary antibodies were detected by an HRP-secondary antibody (anti-mouse or anti-rabbit) followed by incubation with the Lumi-Light detection reagent (Roche, Nutley, NJ). Band intensity was normalized with the $\beta$-actin loading control and the expression level was compared to the vehicle control (ETOH). 


\section{Statistical Methods}

Statistical analysis was determined by using an unpaired, two tailed student's ttest. The results were considered significant if $P<0.05$. All graphs were generated using GraphPad Prism5 software and ModFit (for cell cycle) software.

\section{Results}

\section{Ormeloxifene Alters the Morphology of Cervical Cancer Cells}

Phase contrast microscopic examination of cellular morphology suggested that after indicated time period ormeloxifene promotes clear signs of apoptosis and alters the morphology of treated cells. Cells started becoming round and detaching from the cell culture plate surface; membrane blebbing and shrinkage of cytoplasm could also clearly be seen in representative images of ormeloxifene treated cell (Figure 4-1 and Figure 4-2). These obvious signs are indicative of apoptotic morphological changes. On contrast, the vehicle control ETOH treated cells did not have these changes in morphology. Control group cells were in proper shape and size and attached to the surface of plate.

\section{Ormeloxifene Induces Mitochondrial Membrane Potential}

Decreased mitochondrial membrane potential (MMP) is a clear sign of induction of apoptosis through the mitochondrial intrinsic pathway [190]. TMRE stains healthy and active mitochondria; thus, it is an indicative of live cells. The visual inspection of TMRE stain in Caski and $\mathrm{SiHa}$ cells after 24 hours of ormeloxifene treatment revealed that cells started losing the intensity of TMRE stain with the increasing concentration of ormeloxifene (Figure 4-3 and Figure 4-4). We also performed flow cytometry to measure the quantitative depolarization of mitochondrial membrane in Caski and $\mathrm{SiHa}$ cells and results were consistent. Ormeloxifene significantly decreased mitochondrial membrane potential of both cells in dose dependent manner when compared to its vehicle control ETOH (Figure 4-5 and Figure 4-6).

\section{Ormeloxifene Induces Generation of Reactive Oxygen Species}

Under stress conditions whether its drug treatment or radiation, tumor cells are known to generate of reactive oxygen species (ROS) due to the oxidative stress. Production of reactive oxygen species is one of the key phenomena which leads to apoptosis. We used DCFH-DA stain to detect the amount of reactive oxygen species generation after ormeloxifene treatment in Caski and SiHa cells. DCFH-DA (dichlorodihydrofluorescein diacetate) is a very well-known stain that is used to detect intracellular production of $\mathrm{H}_{2} \mathrm{O}_{2}$. After 24 hours of ormeloxifene treatment at $25 \mu \mathrm{M}$ 

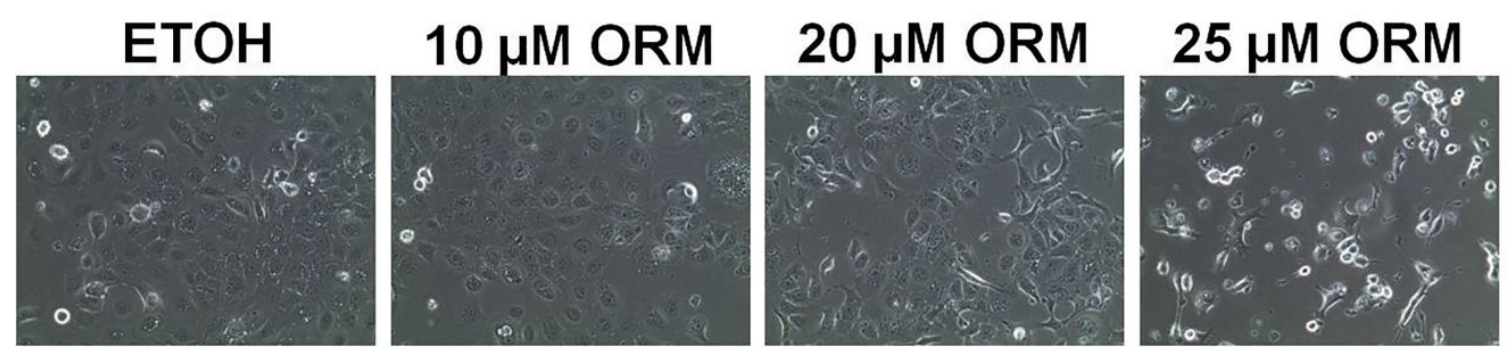

Figure 4-1. Ormeloxifene altered morphology of Caski cells.

Cells were observed and imaged under a phase contrast microscope at 200X after $24 \mathrm{hrs}$ of ormeloxifene treatment. Cells showed clear signs of apoptosis including blebbing and shrinkage.
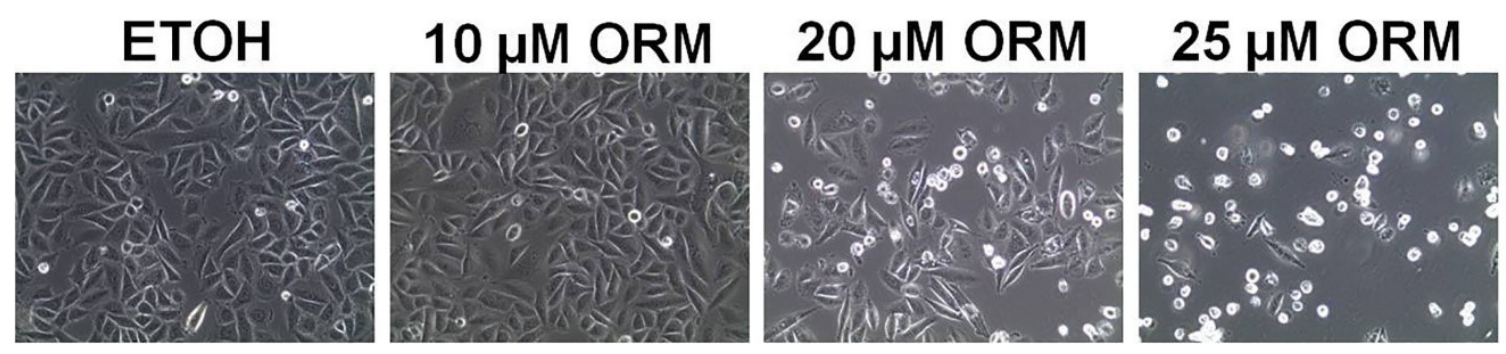

Figure 4-2. Ormeloxifene altered morphology of SiHa cells.

Cells were observed and imaged under a phase contrast microscope at 200X after $24 \mathrm{hrs}$ of ormeloxifene treatment. Cells showed clear signs of apoptosis including blebbing and shrinkage 


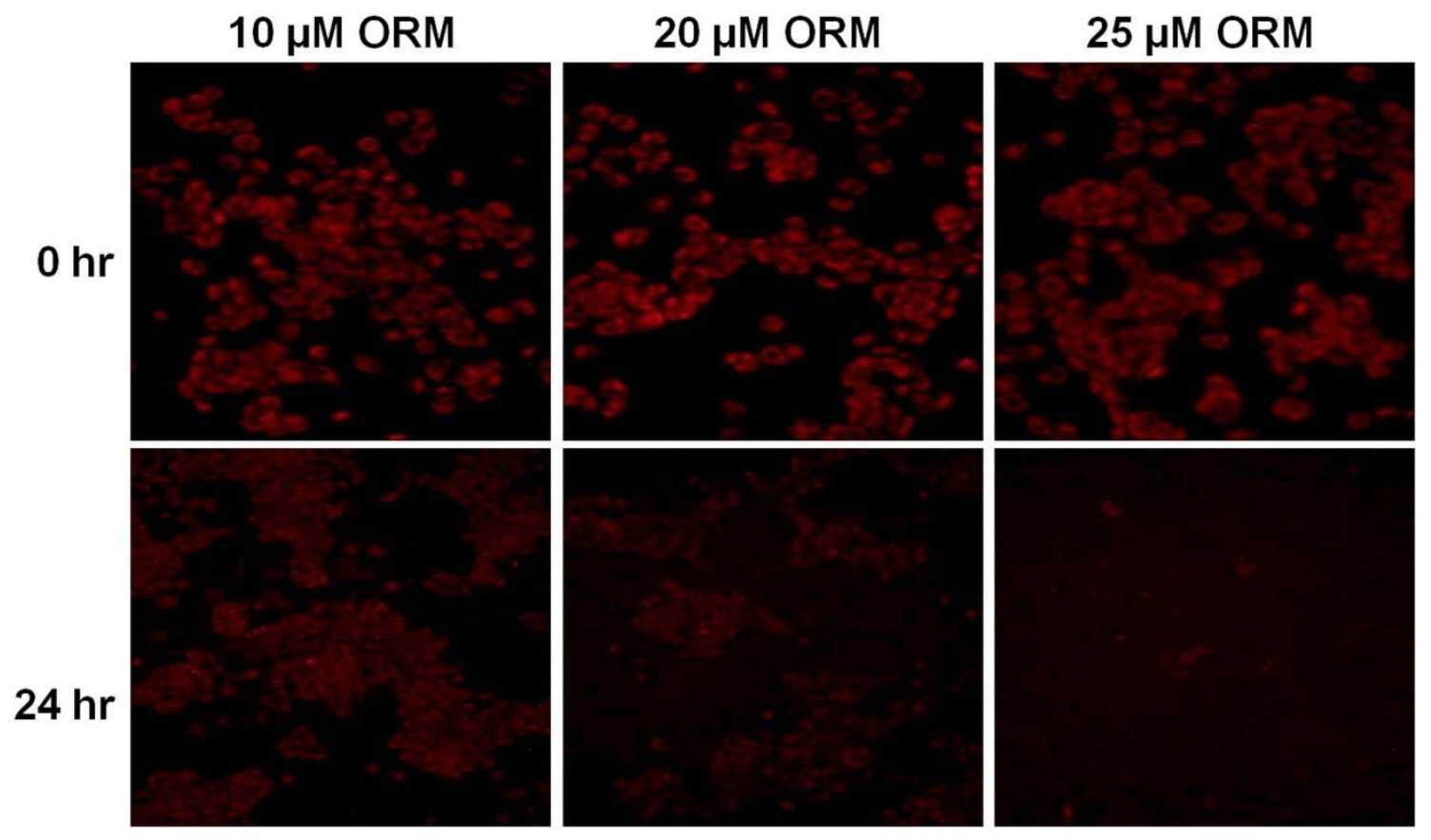

Figure 4-3. Ormeloxifene decreased mitochondrial membrane potential of Caski cells.

Cells were exposed to ormeloxifene treatment for $24 \mathrm{hrs}$ and afterwards stained with TMRE and imaged with a fluorescent microscope at 200X. Cells showed a reduction in TMRE fluorescence. 


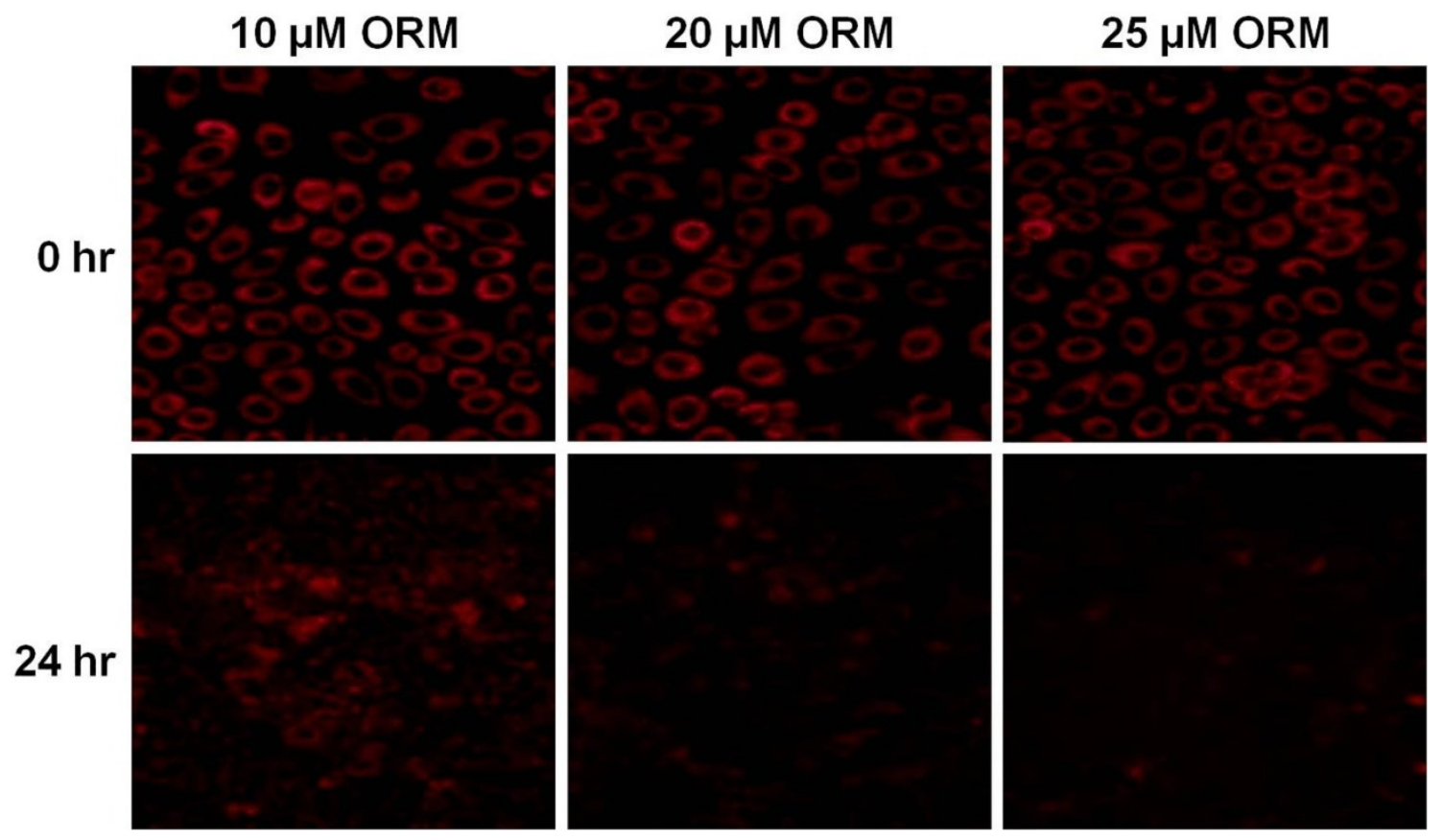

Figure 4-4. Ormeloxifene decreased mitochondrial membrane potential of SiHa cells.

Cells were exposed to ormeloxifene treatment for $24 \mathrm{hrs}$ and afterwards stained with TMRE and imaged with a fluorescent microscope at 200X. Cells showed a reduction in TMRE fluorescence. 


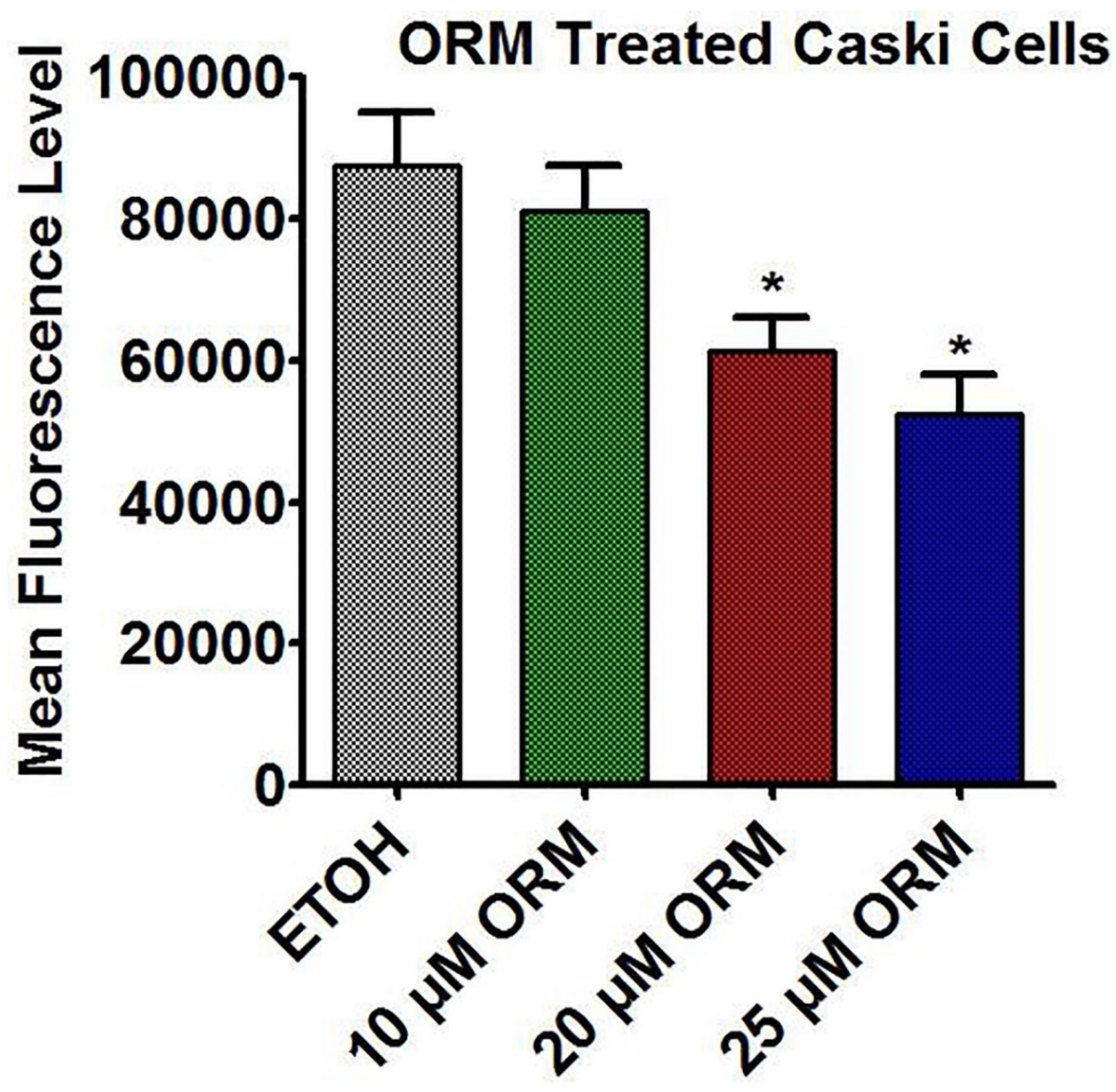

Figure 4-5. Ormeloxifene decreased mitochondrial membrane potential (MMP) of Caski cells.

Cells were treated with ormeloxifene for $24 \mathrm{hrs}$ and stain with TMRE dye to detect the healthy mitochondria. Results were compared to vehicle control ETOH. Error bars show SEM, $\mathrm{n}=3 .{ }^{*} \mathrm{p}<0.05$. 


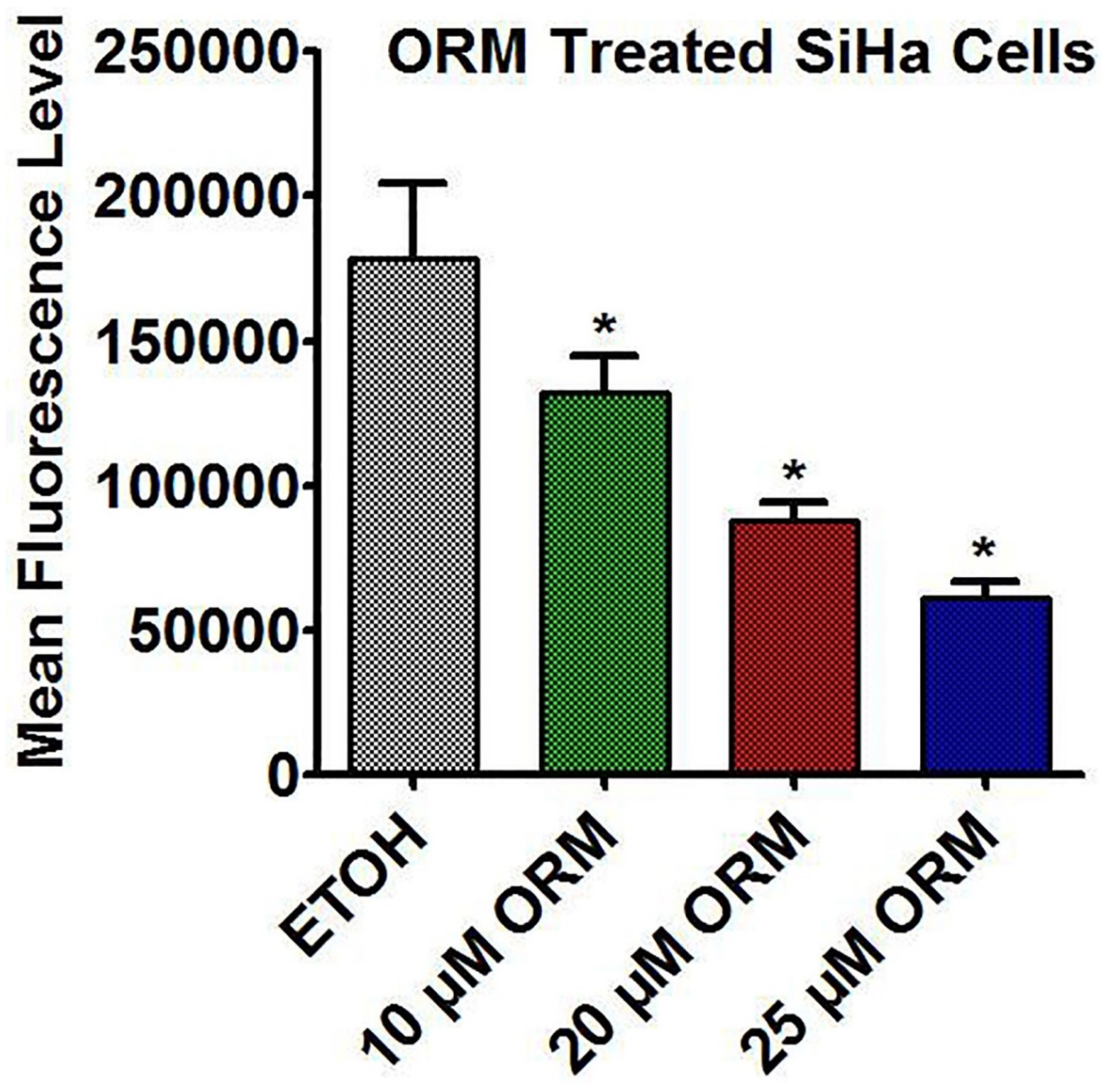

Figure 4-6. Ormeloxifene decreased mitochondrial membrane potential (MMP) of SiHa cells.

Cells were treated with ormeloxifene for $24 \mathrm{hrs}$ and stained with TMRE dye to detect the healthy mitochondria. Results were compared to vehicle control ETOH. Error bars show SEM, $\mathrm{n}=3 .{ }^{*} \mathrm{p}<0.05$. 
concentration, both cell lines showed elevated levels of $\mathrm{H}_{2} \mathrm{O}_{2}$ generation when compared to vehicle control ETOH as confirmed by higher intensity levels of DCFH-DA stain (Figure 4-7 and Figure 4-8).

\section{Ormeloxifene Induces Apoptosis in Cervical Cancer Cells}

We confirmed the ormeloxifene's ability to induce the apoptosis by probing the cells with Annexin V and 7AAD stain. As Annexin V denotes the early apoptosis and 7AAD marks the dead cells. Flow cytometer results illustrated that both Caski and SiHa cells after 24 hours of ormeloxifene treatment at 20 and $25 \mu \mathrm{M}$ concentration showed a marked increase in the percentage of Annexin V positive cell population (Figure 4-9, Figure 4-10, Figure 4-11 and Figure 4-12), confirming the early apoptosis phase. We also observed greater percentage of AnnexinV-7AAD (double stain) positive cells in higher concentration ( $25 \mu \mathrm{M}$ ormeloxifene) treated Caski cells (Figure 4-9) when compared to its vehicle control ETOH, but in a dose dependent manner in SiHa cells (Figure 4-10), confirming the late apoptosis phase.

\section{Ormeloxifene Arrest Cell Cycle in G1-S Transition by Regulating the Expression Level of Transition Related Proteins}

We further validated ormeloxifene's ability to induce apoptosis by performing the cell cycle arrest assay to determine the cell population at different phases of cell cycle. Caski and SiHa cells were treated with 10 and $20 \mu \mathrm{M}$ of ormeloxifene for 24 hours and stained with Propidium Iodide. Cells showed a blockage of progression at G1-S transition (Figure 4-13 and Figure 4-14). Furthermore, we confirmed the cell cycle arrest at G1-S transition by probing for the two transition related molecules Cyclin $\mathrm{E}$ and its dependent kinase; cyclin dependent kinase 2 ( $\mathrm{Cdk} 2)$ utilizing immunoblotting. Ormeloxifene significantly decreased the expression of both the proteins at $20 \mu \mathrm{M}$ concentration when compared to the vehicle control ETOH (Figure 4-15 for immunoblots; Figure 4-16 and Figure 4-17 for density quantification).

\section{Ormeloxifene Downregulates PI3K-Akt Pathway}

PI3K-Akt cell survival oncogenic pathway is overly expressed in cervical cancer cells. The pathway is required for cell cycle progression from G1 phase to S phase. Inhibition of PI3K-Akt pathway is an important tool for developing the treatment strategies for cervical cancer. We utilized immunoblotting assay to evaluate the inhibitory effects of ormeloxifene on PI3K-Akt pathway. Ormeloxifene decreased the total Akt expression slightly but phosphorylated and active form of Akt (pAkt) and PI3K were decreased markedly (Figure 4-18). Figure 4-19, Figure 4-20 and Figure 4-21 indicate the densitometric analysis of band intensity of immunoblots showed in Figure 4-18. 


\section{ORM Treated Caski Cells}

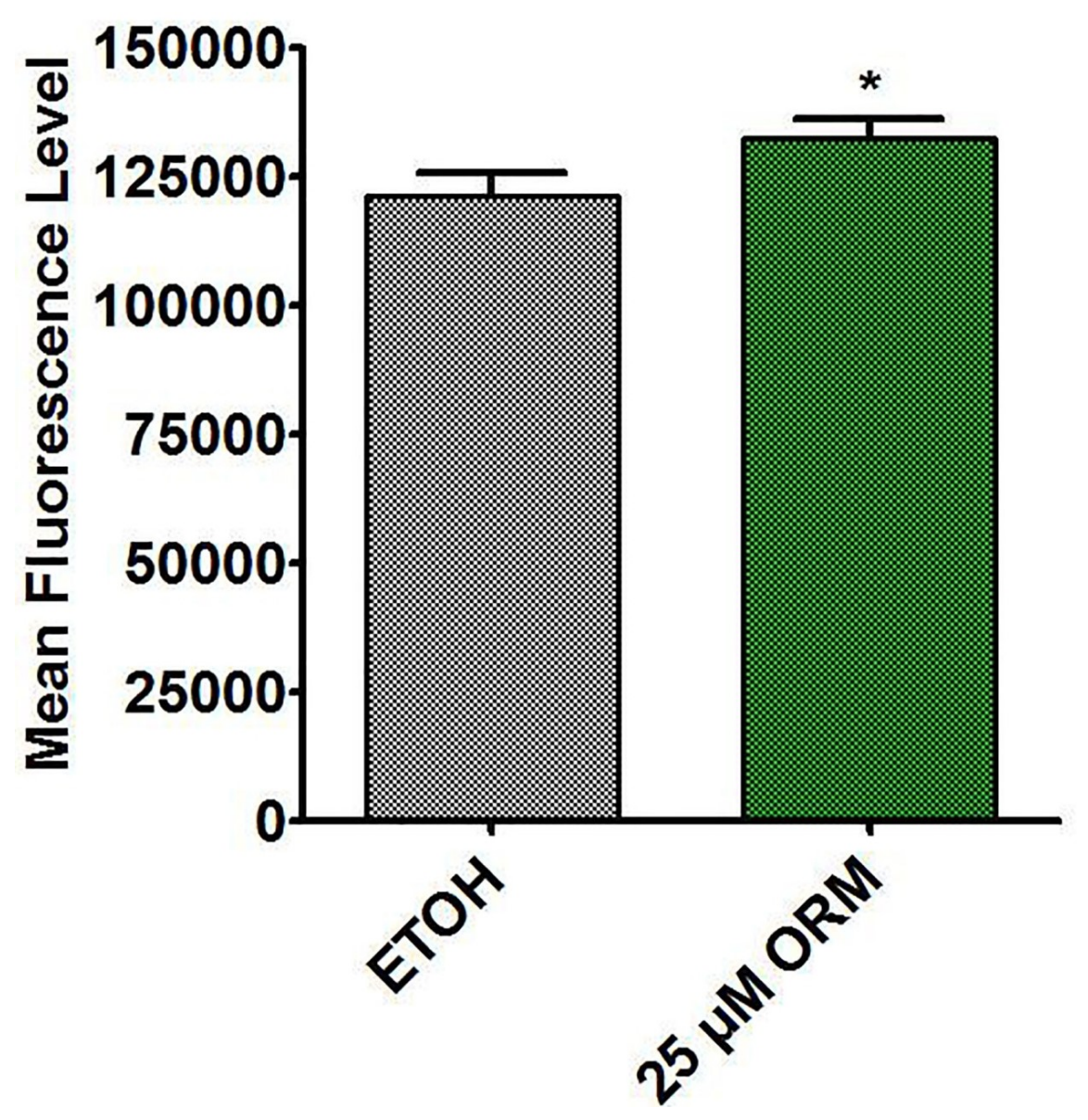

Figure 4-7. Ormeloxifene enhanced the generation of reactive oxygen species (ROS) in Caski cells.

Cels were treated with ormeloxifene for $24 \mathrm{hrs}$ and stain with DCFH-DA dye to detect $\mathrm{H}_{2} \mathrm{O}_{2}$ formation. Results were compared to vehicle control ETOH. Error bar shows SEM, $\mathrm{n}=3 .{ }^{*} \mathrm{p}<0.05$. 


\section{ORM Treated SiHa Cells}

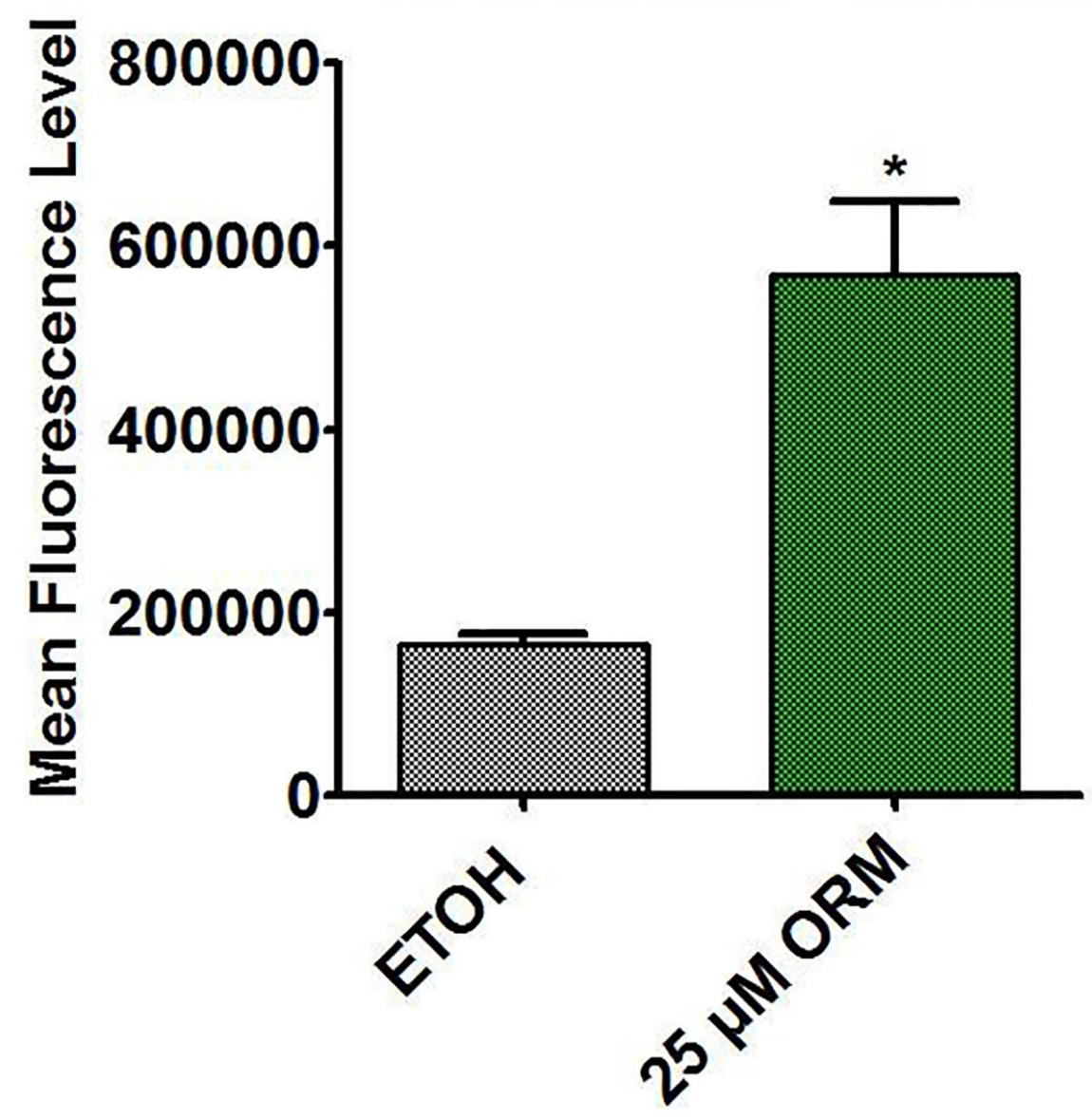

Figure 4-8. Ormeloxifene enhanced the generation of reactive oxygen species (ROS) in SiHa cells.

Cells were treated with ormeloxifene for $24 \mathrm{hrs}$ and stain with DCFH-DA dye to detect $\mathrm{H}_{2} \mathrm{O}_{2}$ formation. Results were compared to vehicle control ETOH. Error bar shows SEM, $\mathrm{n}=3 .{ }^{*} \mathrm{p}<0.05$. 
ETOH

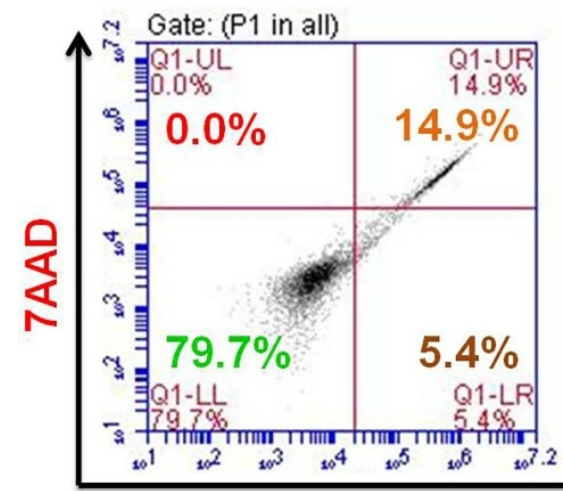

$20 \mu \mathrm{M}$ ORM

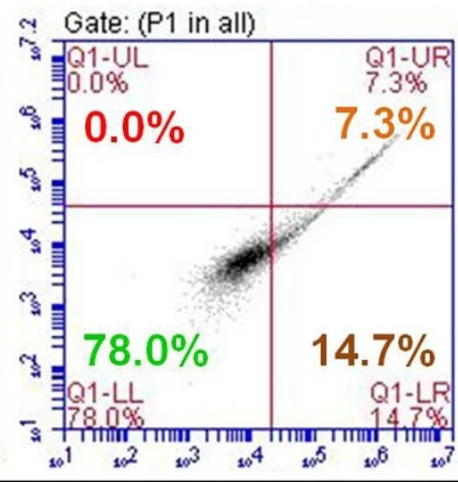

Annexin V
$25 \mu \mathrm{M}$ ORM

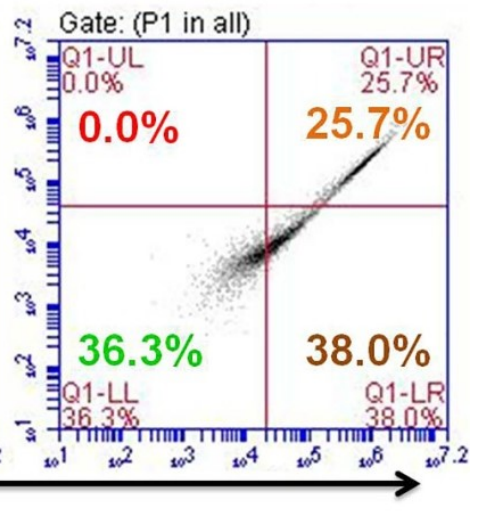

Negative: Live

7AAD Positive: Dead (Necrotic)

Annexin V Positive: Apoptotic

Annexin V- 7AAD Positive: Apoptotic Dead

Figure 4-9. Cell population diagram of Caski cells obtained with Flow Cytometer representing percentage of cells stained with either Annexin $V$ or 7AAD or both or none.

ETOH

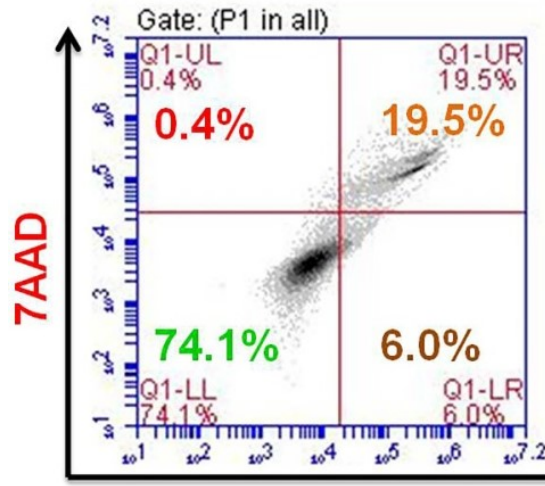

$20 \mu \mathrm{M}$ ORM

Gate: (P1 in all)

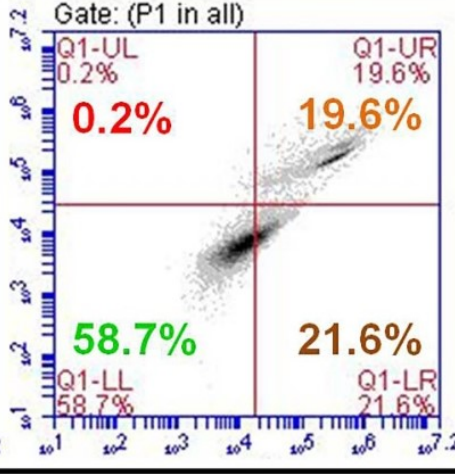

$25 \mu \mathrm{M}$ ORM

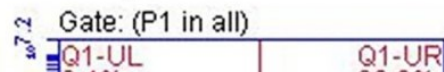

= $0.4 \%$

$0.4 \%$

害

言

自

"

$28.8 \%$

唯- $\mathrm{LL}$

$-7288 \%$

Annexin V

Negative: Live

7AAD Positive: Dead (Necrotic)

Annexin V Positive: Apoptotic

Annexin V-7AAD Positive: Apoptotic Dead

Figure 4-10. Cell population diagram of SiHa cells obtained with Flow Cytometer representing percentage of cells stained with either Annexin $V$ or 7AAD or both or none. 


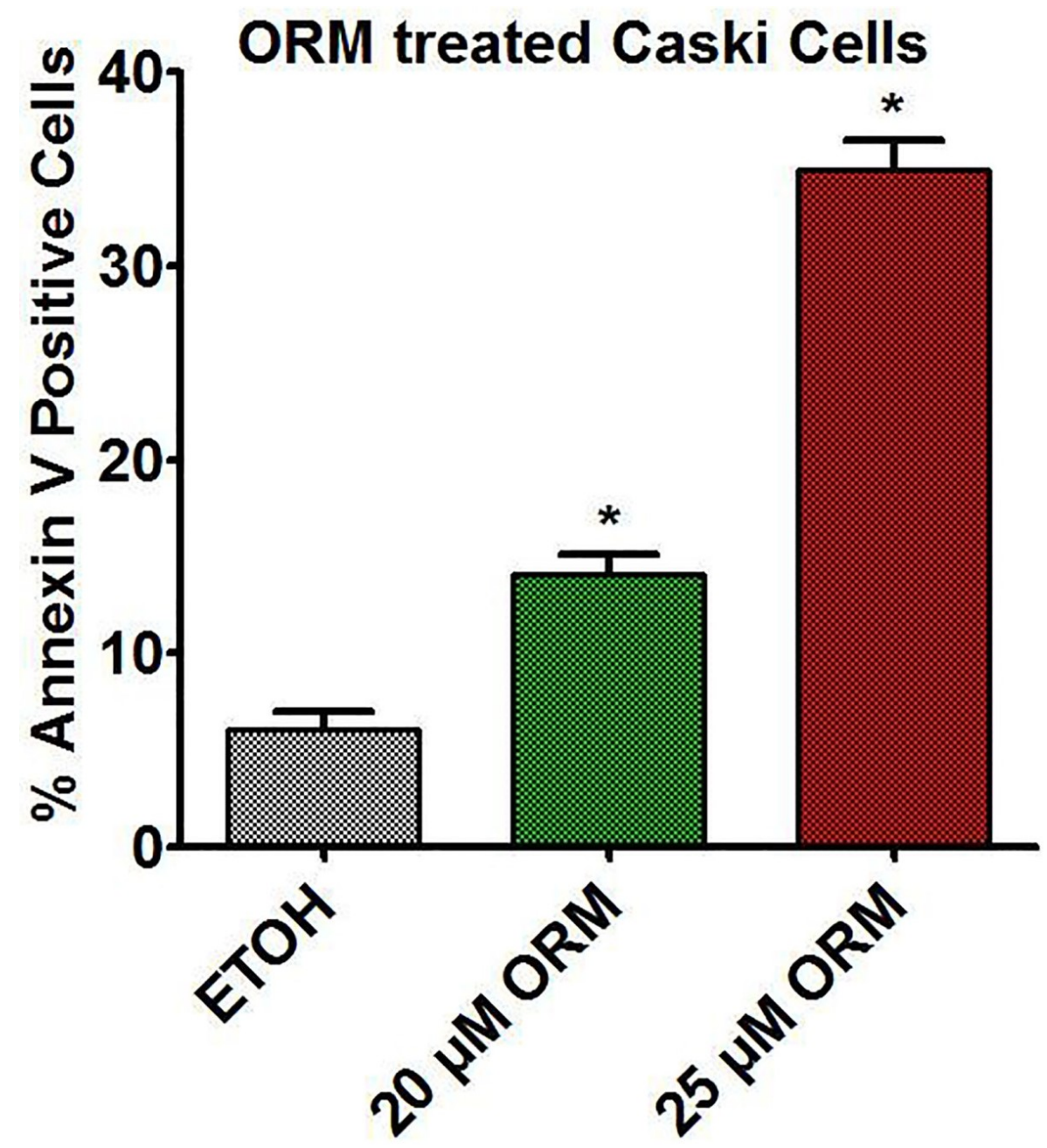

Figure 4-11.Ormeloxifene induced apoptosis of Caski cells.

Cells were treated with ormeloxifene for 24 hours and analyzed by flow cytometry using Annexin V and 7AAD dyes. Results were compared to vehicle control ETOH. Error bars show SEM, $\mathrm{n}=3 .{ }^{*} \mathrm{p}<0.05$. 


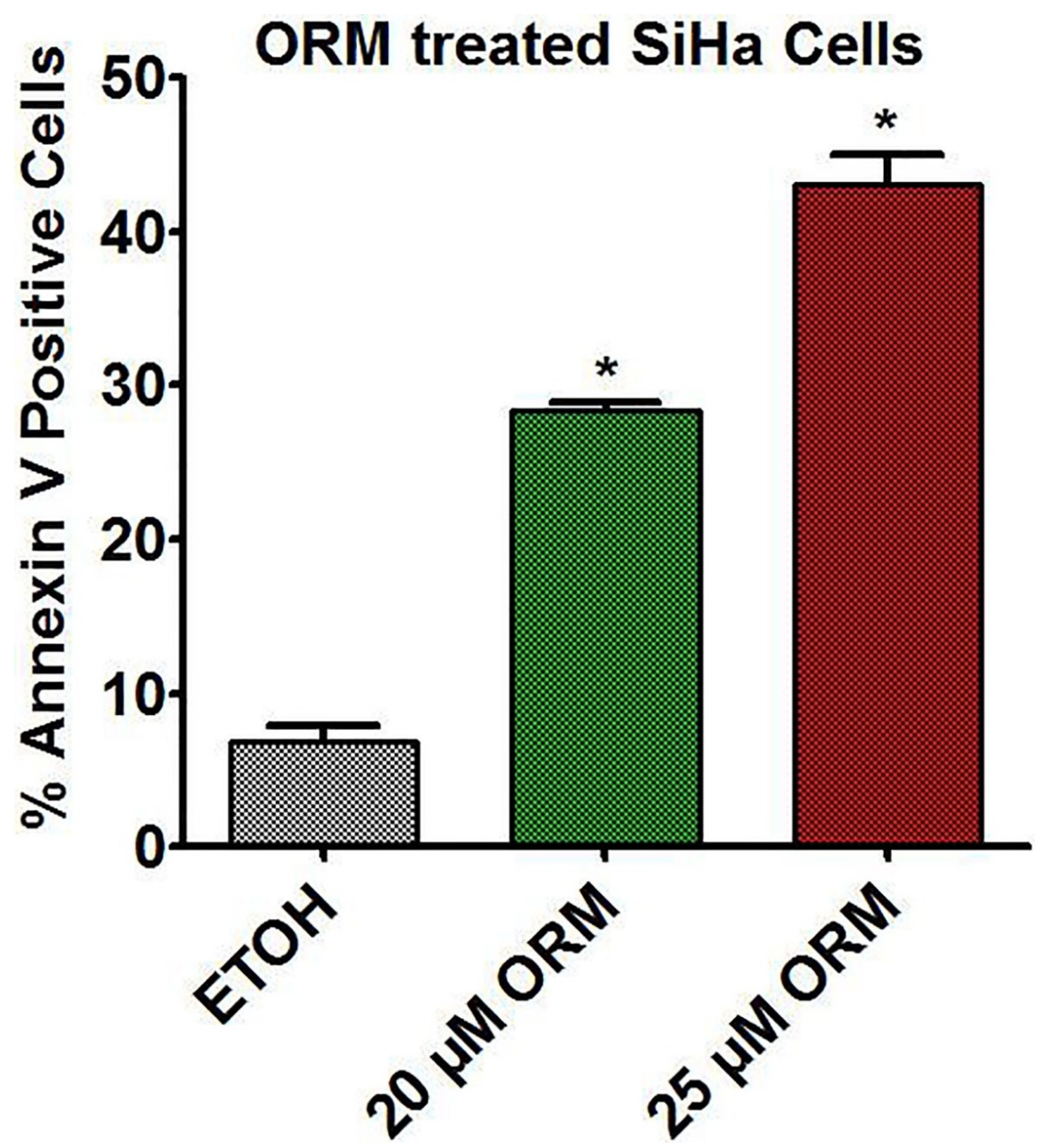

Figure 4-12. Ormeloxifene induced apoptosis of SiHa cells.

Cells were treated with ormeloxifene for 24 hours and analyzed by flow cytometry using Annexin $\mathrm{V}$ and 7AAD dyes. Results were compared to vehicle control ETOH. Error bars show SEM, $\mathrm{n}=3 .{ }^{*} \mathrm{p}<0.05$. 

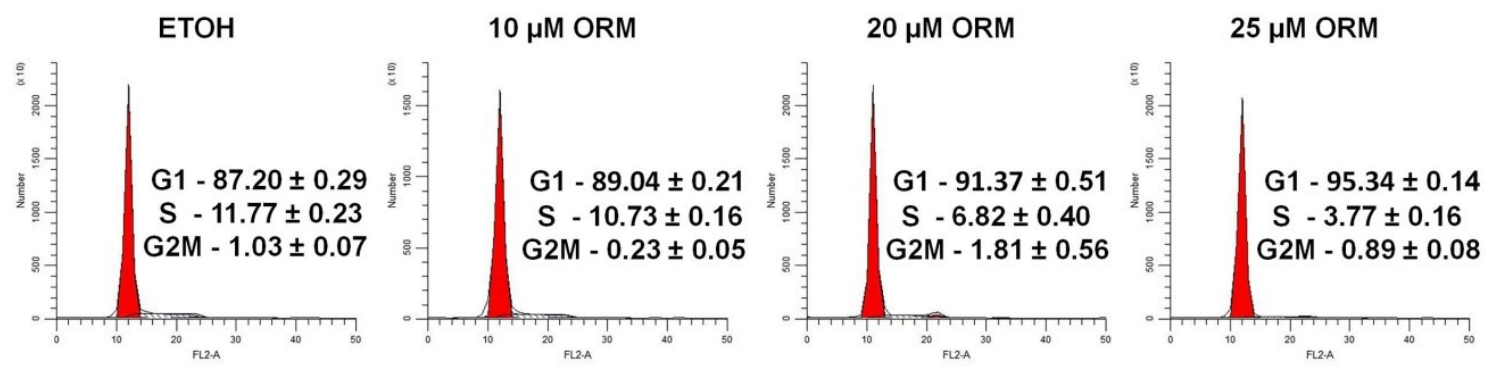

Figure 4-13. Ormeloxifene arrested cell cycle at G1-S transition in Caski Cells. Cell cycle population diagram of Caski cells obtained with ModFit software representing percentage of different cell population stained with propidium iodide.

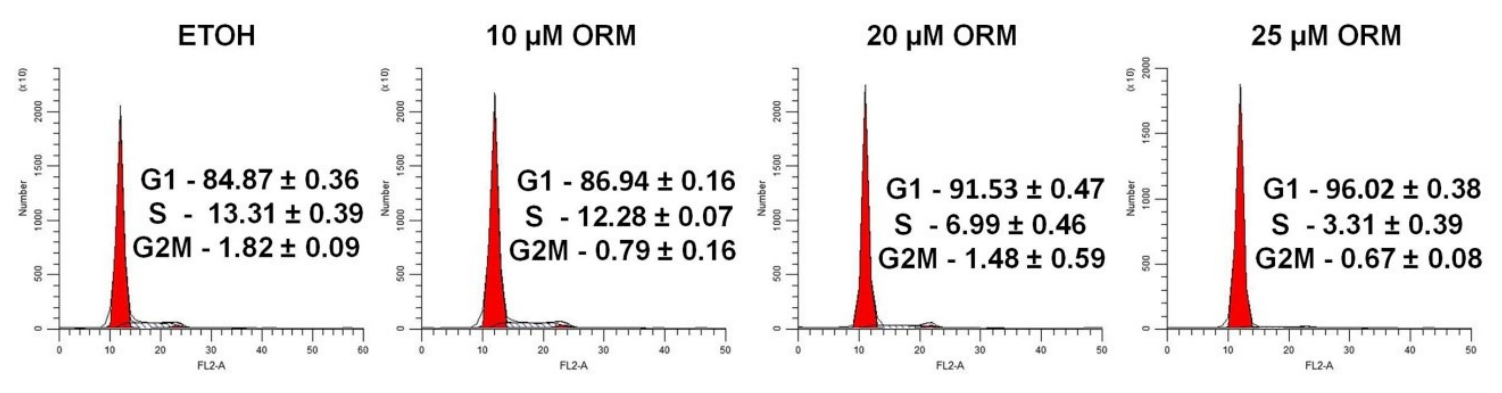

Figure 4-14. Ormeloxifene arrested cell cycle at G1-S transition in SiHa cells.

Cell cycle population diagram of $\mathrm{SiHa}$ cells obtained with ModFit software representing percentage of different cell population stained with propidium iodide. 


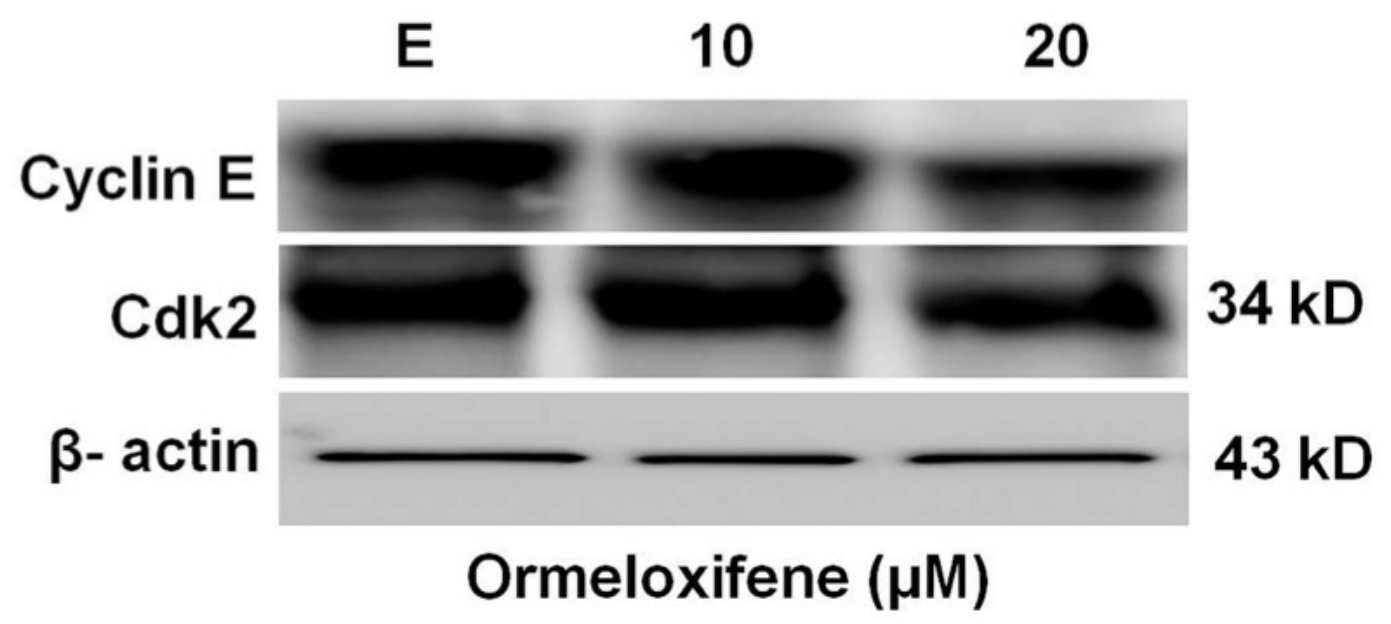

Figure 4-15. Ormeloxifene downregulated the expression levels of Cyclin E and Cdk2 in Caski cells.

Cells were treated with ormeloxifene for $24 \mathrm{hrs}$ and immunoblots were preformed to detect Cyclin E and Cdk2 proteins. $\beta$-actin was used as a loading control. 


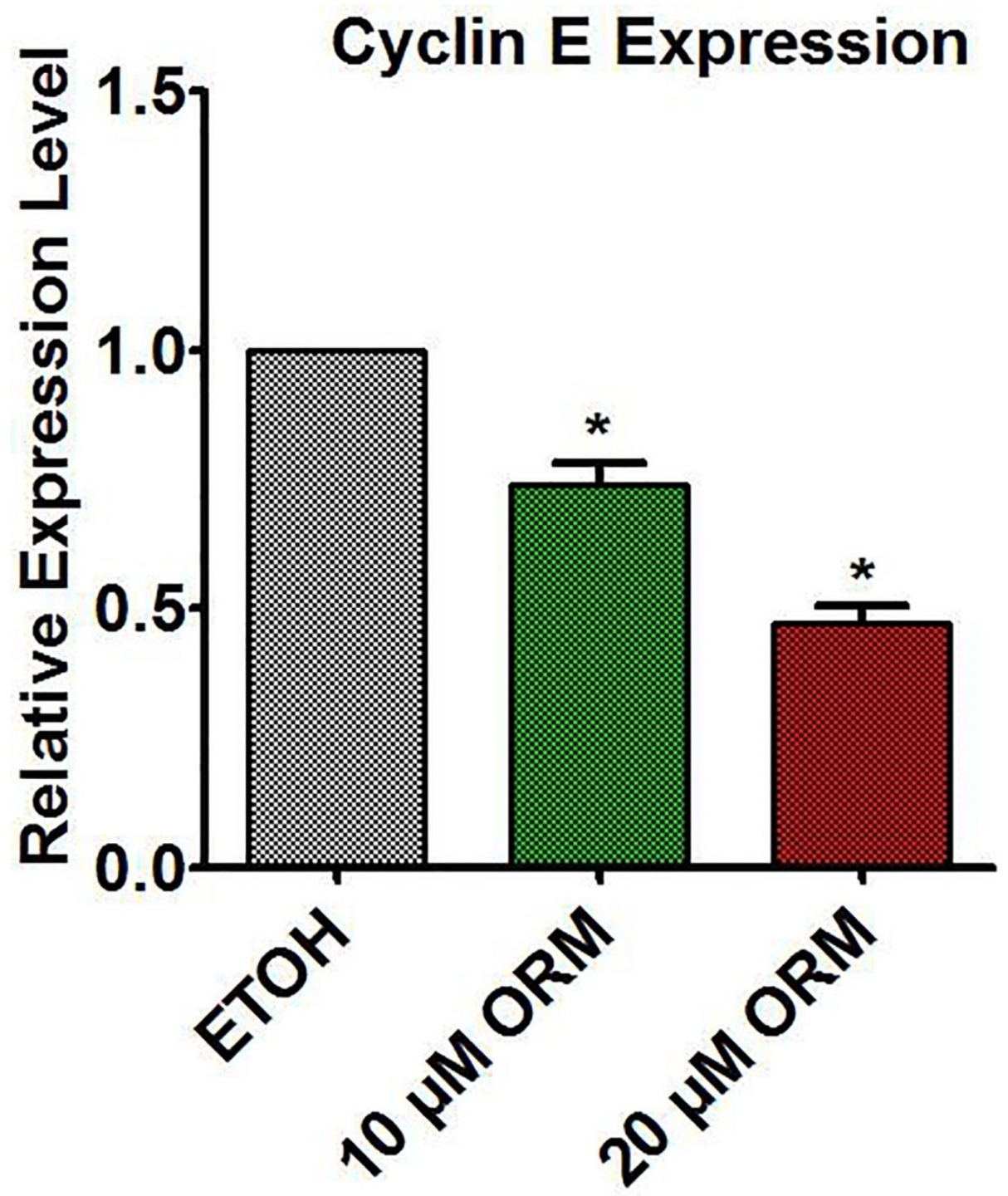

Figure 4-16. Densitometric quantitation of band intensity of Cyclin $\mathbf{E}$.

Band intensity was normalized to $\beta$-actin and scaled to the ETOH control. Bars $=$ Relative Expression Level, Error bars show SEM, $n=3$. ${ }^{*} p<0.05$. 


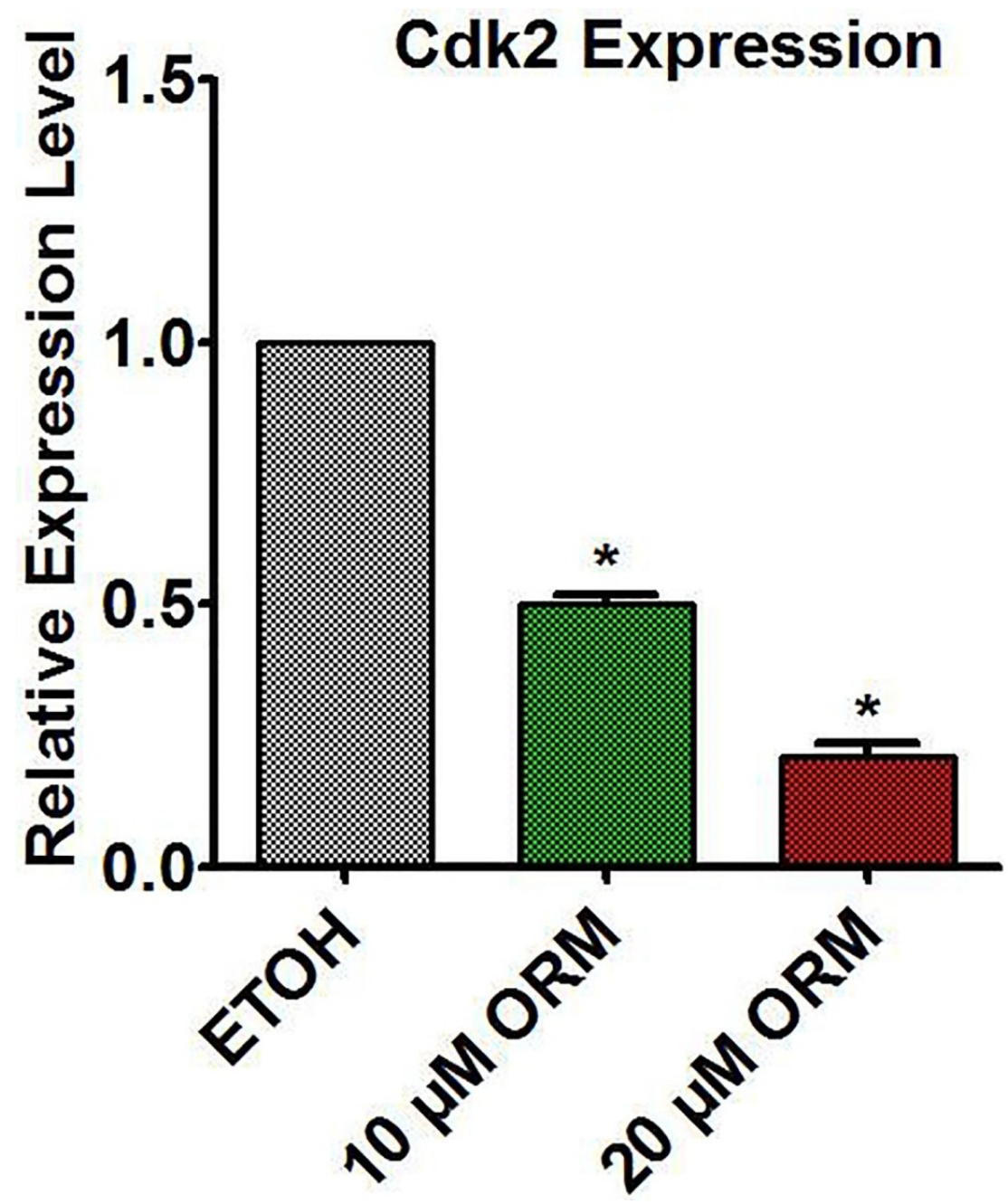

Figure 4-17. Densitometric quantitation of band intensity of Cdk2.

Band intensity was normalized to $\beta$-actin and scaled to the ETOH control. Bars $=$ Relative Expression Level, Error bars show SEM, $n=3{ }^{*} \mathrm{p}<0.05$. 

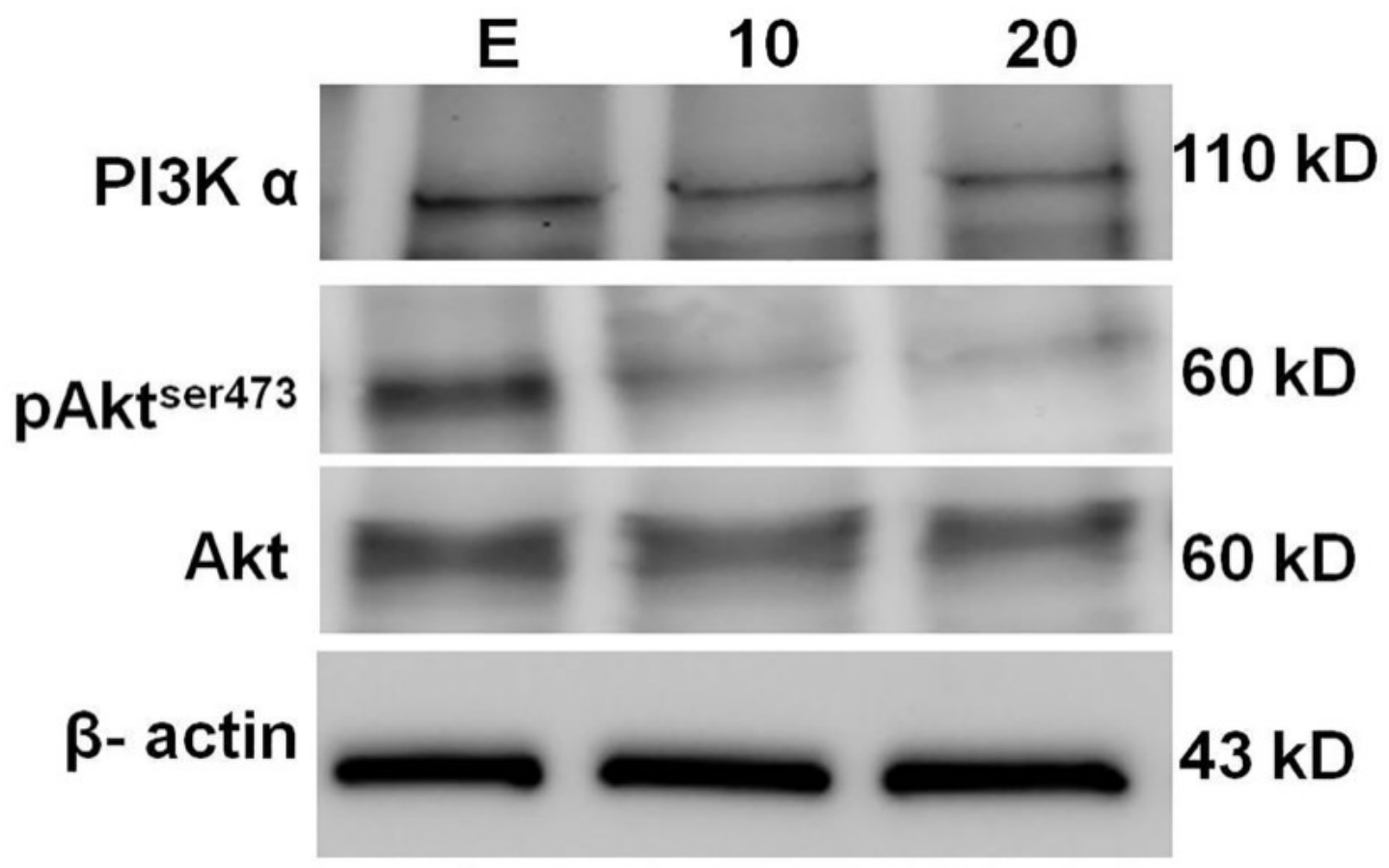

\section{Ormeloxifene $(\mu \mathrm{M})$}

Figure 4-18. Ormeloxifene downregulated the expression levels of PI3K/Akt pathway in Caski cells.

Cells were treated with ormeloxifene for $24 \mathrm{hrs}$ and immunoblots were preformed to detect PI3K, Akt and pAkt proteins. $\beta$-actin was used as a loading control. 


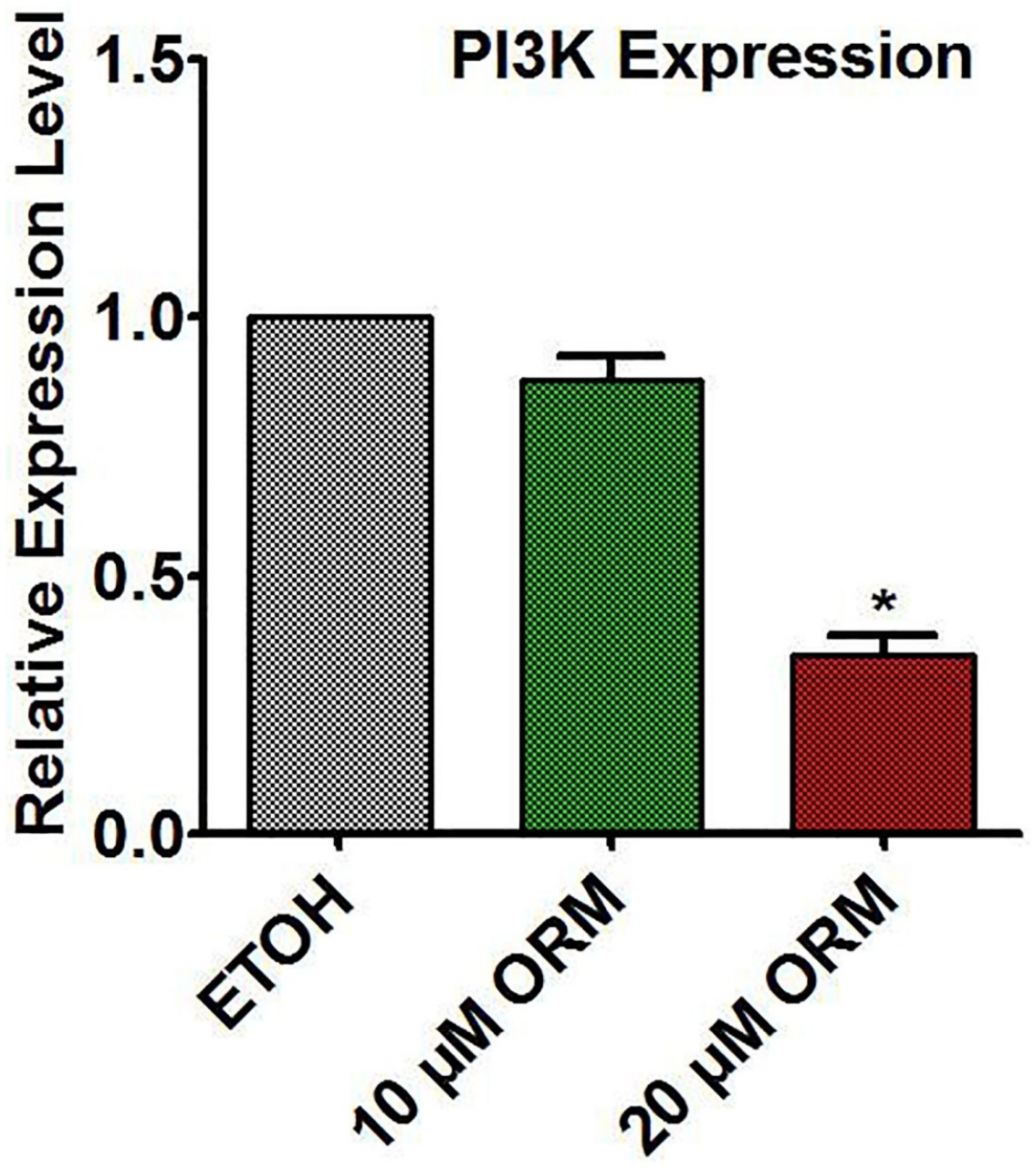

Figure 4-19. Densitometric quantitation of band intensity of PI3K.

Band intensity was normalized to $\beta$-actin and scaled to the ETOH control. Bars $=$ Relative Expression Level, Error bars show SEM, $n=3$. ${ }^{*} \mathrm{p}<0.05$. 


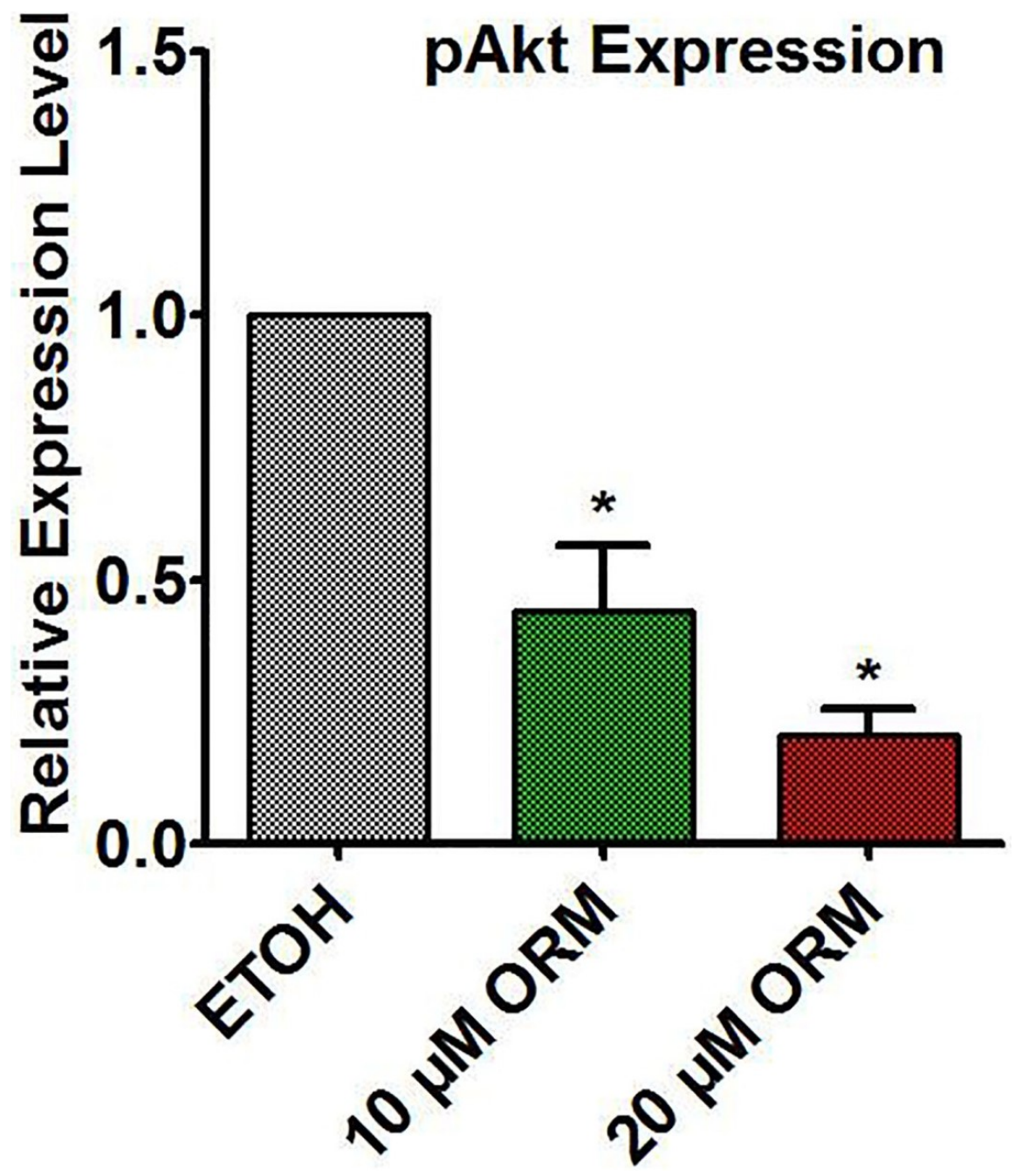

Figure 4-20. Densitometric quantitation of band intensity of pAkt.

Band intensity was normalized to $\beta$-actin and scaled to the ETOH control. Bars $=$ Relative Expression Level, Error bars show SEM, $n=3$. ${ }^{*} \mathrm{p}<0.05$. 


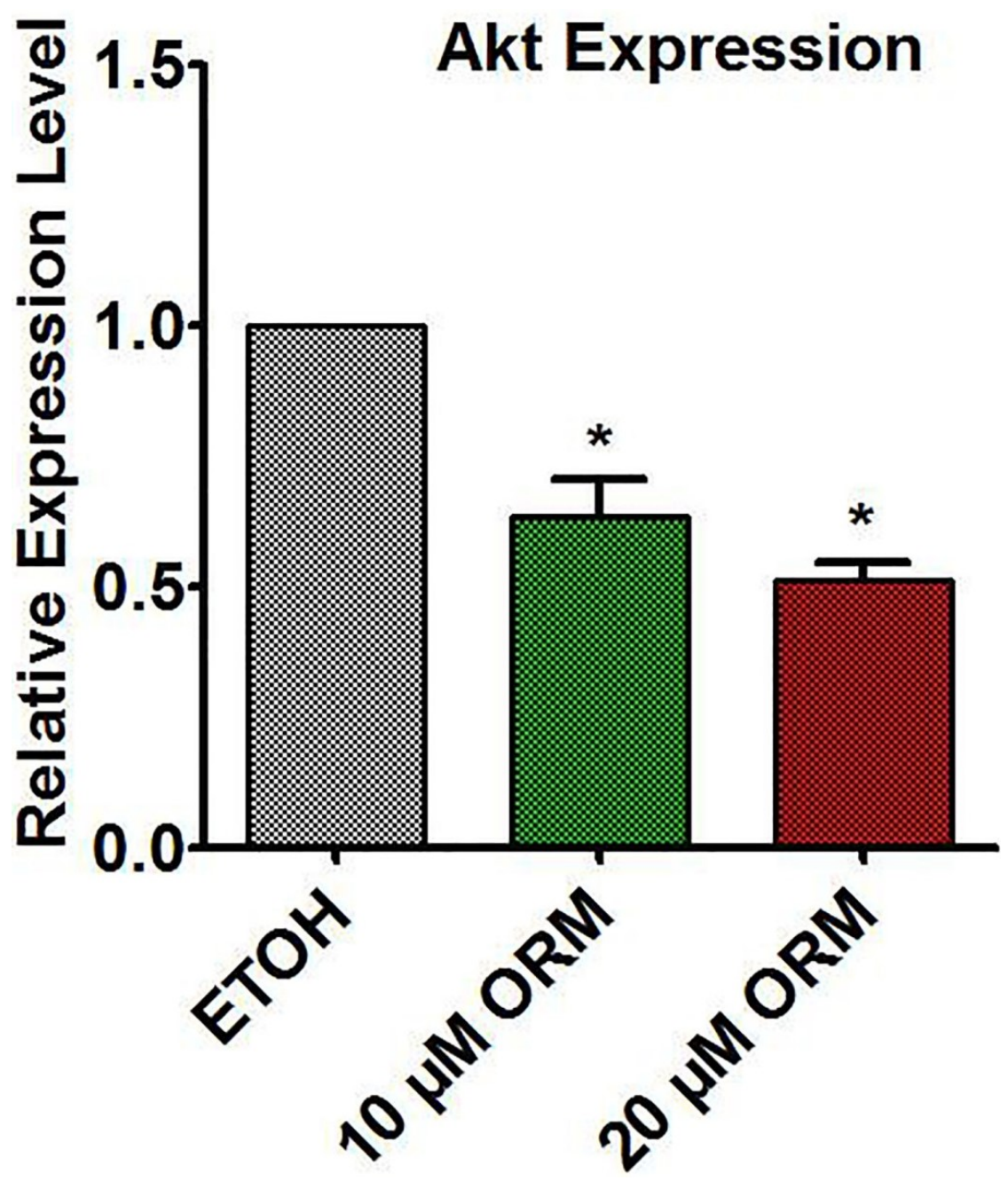

Figure 4-21. Densitometric quantitation of band intensity of Akt.

Band intensity was normalized to $\beta$-actin and scaled to the ETOH control. Bars $=$ Relative Expression Level, Error bars show SEM, $n=3 .{ }^{*} p<0.05$. 


\title{
CHAPTER 5. ANALYSIS OF ORMELOXIFENE'S EFFECT ON HPV REGULATION ONCOGENESIS IN CERVICAL CANCER
}

\author{
Materials and Methods
}

\section{Quantitative PCR}

$1 \mathrm{X} 10^{6}$ Caski cells were plated per $100 \mathrm{~mm}$ dish and allowed to attach overnight. After 24 hours cells were treated with ormeloxifene at 2 different micromolar concentrations $(10 \mu \mathrm{M}$ and $20 \mu \mathrm{M})$ for 6 hours. After indicated time, adherent cells were collected and RNA was extracted with the Qiagen RNeasy kit (Qiagen Inc., Valencia, CA). Reverse transcription was performed with the High Capacity RNA to cDNA kit and amplified with SYBR Green PCR master mix (both from Applied Biosystems). The cDNA was amplified with primers specific for HPV16 E6, HPV16 E7 and $\beta 2-$ microglobulin. E6-F: caaaccgttgtgtgatttgttaatta; E6-R: gctttttgtccagatgtctttgc; E7-F: ccggacacagccattacaa; $\mathrm{E} 7-\mathrm{R}$ : cgaatgtctacgtgtgtgctttg; $\beta 2 \mathrm{M}-\mathrm{F}$ : tgagtatgectgccgtgtga; $\beta 2 \mathrm{M}-\mathrm{R}$ : tgatgetgcttacatgtctcgat [130]. Each reaction was performed in duplicate with a MyiQ single color real time PCR thermo cycler and analyzed with Genex (Microsoft Excel macro provided by BioRad). The results were first normalized to the endogenous control ( $\beta 2$-microglobulin) and then the expression level was scaled to the vehicle control $(\mathrm{ETOH})$.

\section{Immunoblotting}

Caski and $\mathrm{SiHa}\left(1 \times 10^{6}\right)$ cells were plated per $100 \mathrm{~mm}$ dish and allowed to attach overnight. Next day cells were treated with different micro molar concentrations of ormeloxifene for 24 hours. After treatment, both adherent and floating cells were collected in 2x SDS lysis buffer (Santa Cruz Biotechnologies, Santa Cruz, CA), sonicated and the protein concentration was normalized using SYPRO- Orange (Molecular Probes). SDS - PAGE electrophoresis was done using 10\% gradient gel and resolved proteins were transferred onto PVDF (BioRad, Hercules, CA) membrane. HPV 16 E6/E7 (Abcam), PI3K, Akt, pAkt, Rb, PTPN13, Cyclin E and Cdk2 (Cell Signaling) and p53 (Santa Cruz) primary antibodies were used. The primary antibodies were detected by an HRP-secondary antibody (anti-mouse or anti-rabbit) followed by incubation with the Lumi-Light detection reagent (Roche, Nutley, NJ). Band intensity was normalized with the $\beta$-actin loading control and the expression level was compared to the vehicle control $(\mathrm{ETOH})$. 


\section{Statistical Methods}

Statistical analysis was determined by using an unpaired, two tailed student's t-test. The results were considered significant if $P<0.05$. All graphs were generated using GraphPad Prism5 software.

\section{Results}

\section{Ormeloxifene Decreases the Expression of HPV Oncogenes E6 and E7}

Oncogenes E6 and E7 are responsible for continuous cell division which results in development of cervical cancer. Expression of human papillomavirus E6 and E7 is a very important consideration for cervical cancer treatment. Quantitative RT - PCR was performed to determine the expression of HPV oncogenes E6 and E7 in Caski cells. Ormeloxifene significantly inhibits the expression of E6 and E7 after 6 hours of Ormeloxifene treatment (10 $\mu \mathrm{M}$ and $20 \mu \mathrm{M}$ doses) (Figure 5-1 and Figure 5-2). The indicated treatment was compared with vehicle control ETOH. We also assessed the downregulation of oncogenic signaling at the translational level by performing immunoblotting. Both oncoproteins showed a marked reduction in the expression level compared to the vehicle control ETOH (Figure 5-3). Figure 5-4 and Figure 5-5 indicate the densitometric analysis of band intensity of Figure 5-3.

\section{Ormeloxifene Restores the Tumor Suppressor Signaling}

The oncogenic properties of HPV E6 and E7 are increased when E6 and E7 bind to the suppressor proteins $\mathrm{p} 53, \mathrm{Rb}$ and PTPN13. Ormeloxifene's effect on these tumor suppressing molecules was determined by the immunoblotting assays. We treated Caski cervical cancer cells with 10 and $20 \mu \mathrm{M}$ concentration of ormeloxifene for 24 hours and probed for three tumor suppressor proteins. We observed a slight but noticeable decrease in the expression of wild type $\mathrm{p} 53$, but $\mathrm{Rb}$ and PTPN13 proteins also showed a marked decrease in the expression after ormeloxifene treatment at $20 \mu \mathrm{M}$ dose (Figure 5-6).

Figure 5-7, Figure 5-8 and Figure 5-9 indicate the densitometric analysis of band intensity of Figure 5-6. 


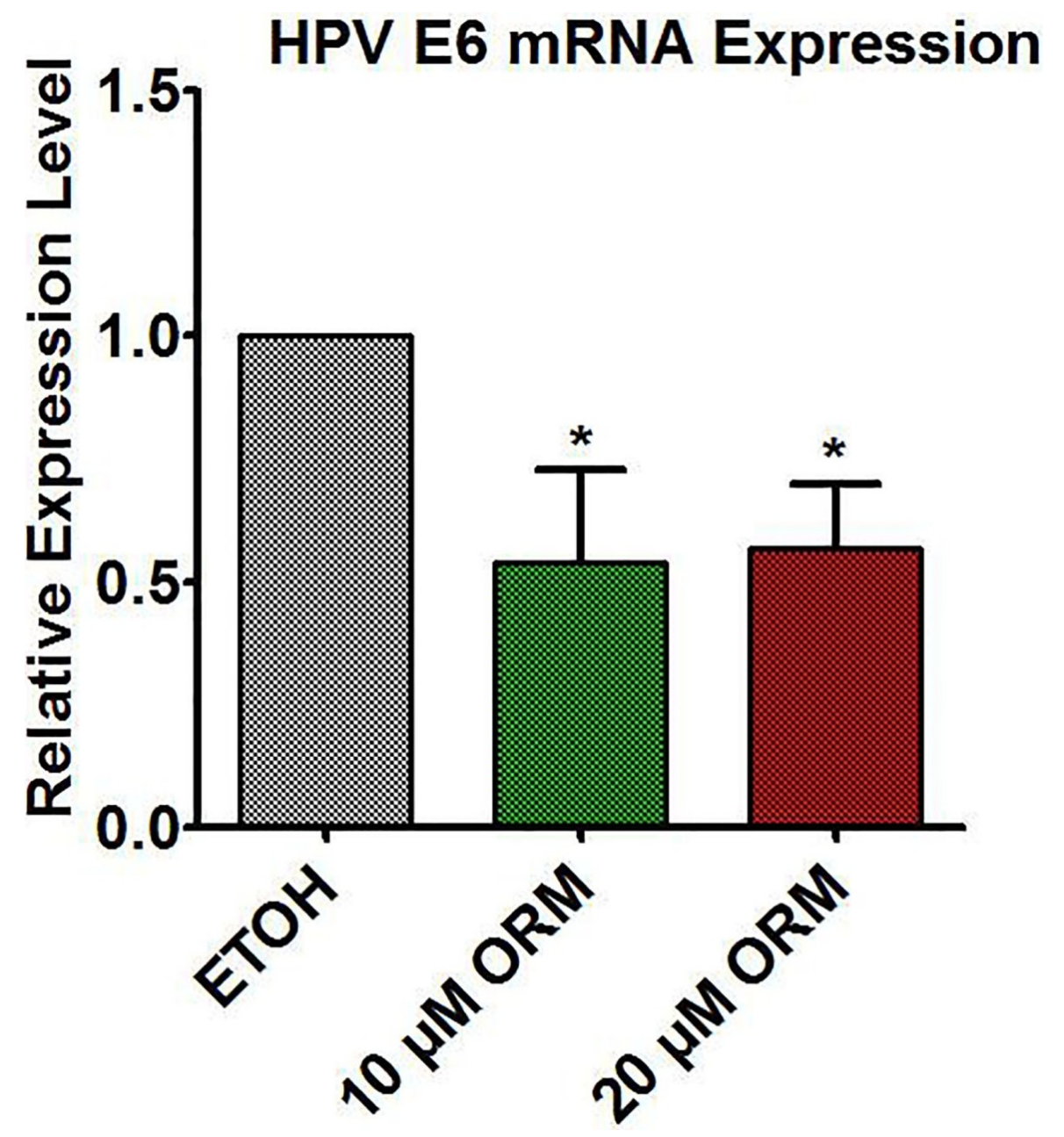

Figure 5-1. Ormeloxifene decreased HPV E6 mRNA.

Caski cells were treated with ormeloxifene for $6 \mathrm{hrs}$ and mRNA level of HPV E6 was determined by quantitative PCR. Expression levels were normalized to a house keeping gene $(\beta$-2-Microgloblin) and scaled to the vehicle control $(\mathrm{ETOH})$. Bars $=$ Relative Expression Level, Error bars show SEM, $n=3$. ${ }^{*} p<0.05$. 


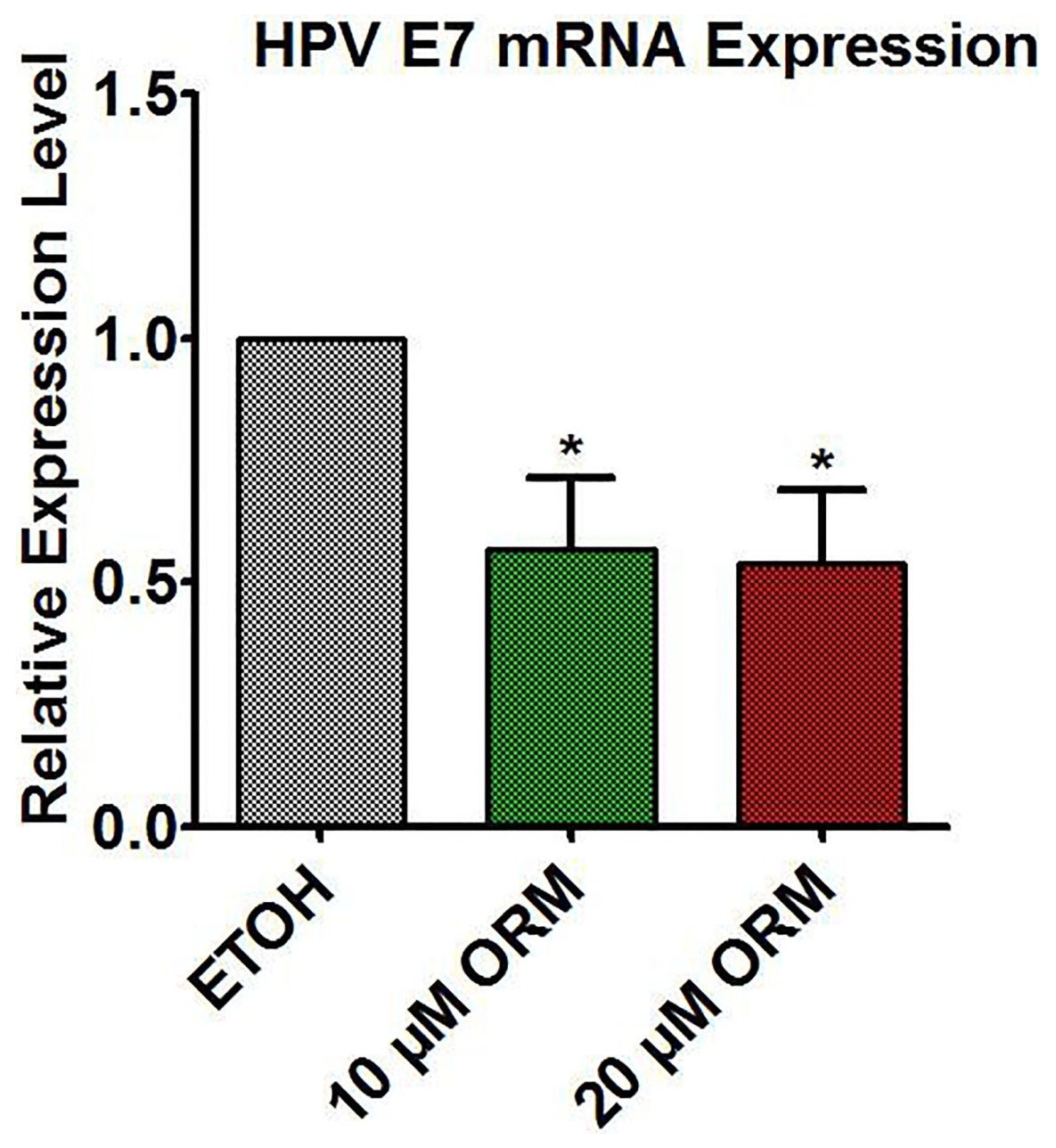

Figure 5-2. Ormeloxifene decreased HPV E7 mRNA.

Caski cells were treated with ormeloxifene for 6 hrs and mRNA level of HPV E7 was determined by quantitative PCR. Expression levels were normalized to a house keeping gene ( $\beta$-2-Microgloblin) and scaled to the vehicle control $(\mathrm{ETOH}) . \quad$ Bars $=$ Relative Expression Level, Error bars show SEM, $\mathrm{n}=3$. ${ }^{*} \mathrm{p}<0.05$. 


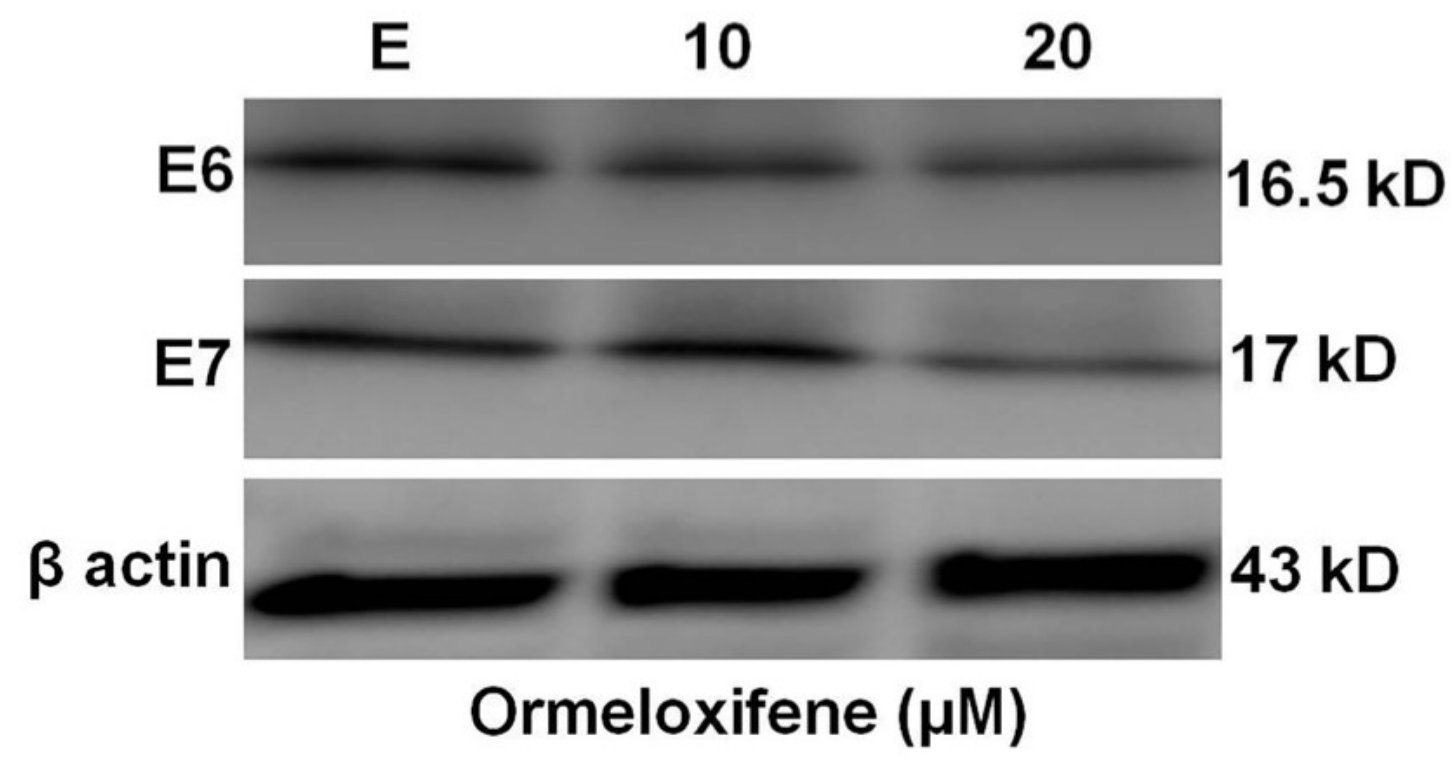

Figure 5-3. Ormeloxifene inhibited HPV E6 and E7 proteins.

Caski cells were treated with ormeloxifene for $24 \mathrm{hrs}$ and immunoblots were preformed to detect HPV E6 and E7 proteins. $\beta$-actin was used as a loading control. 


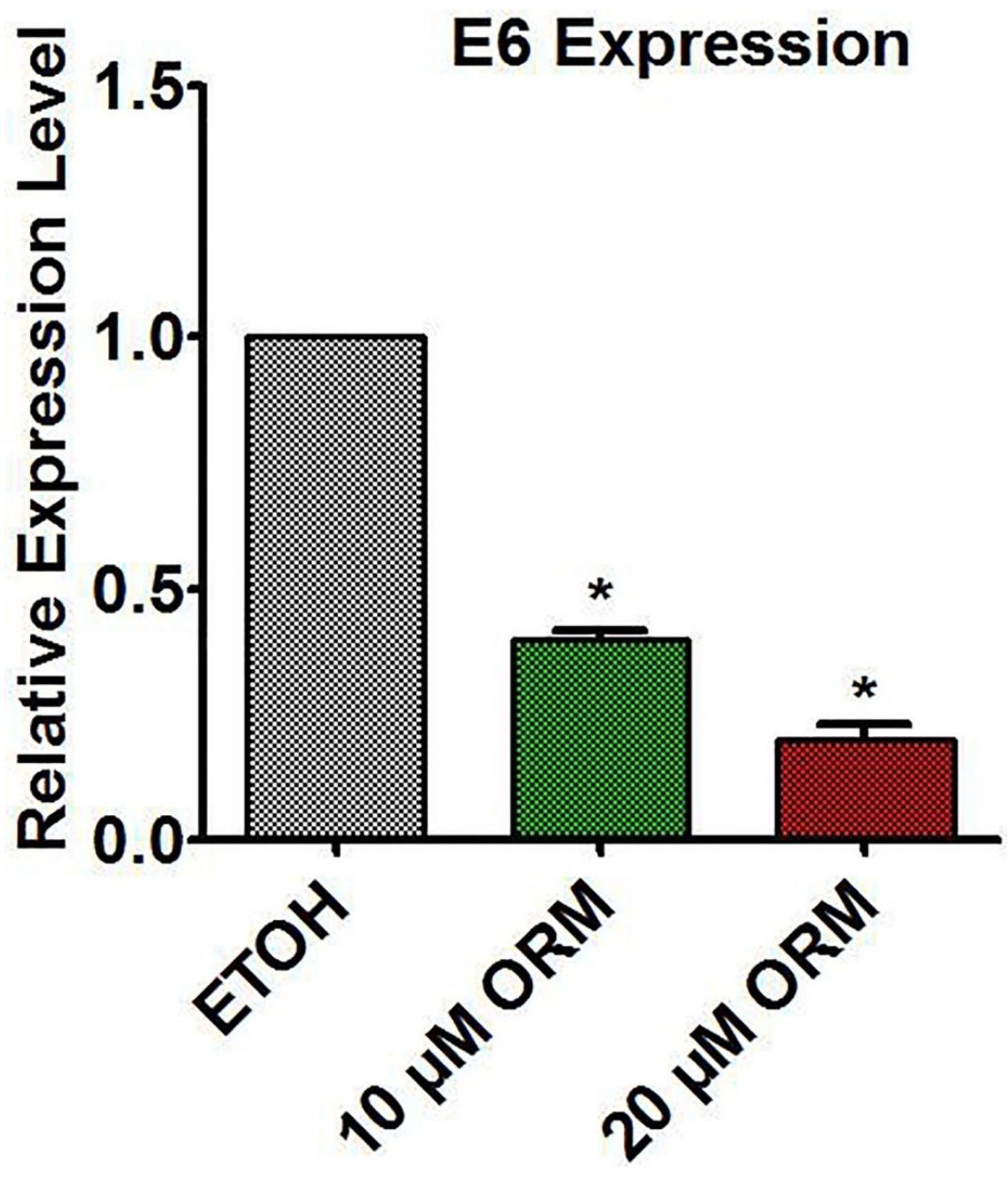

Figure 5-4. Densitometric quantitation of band intensity of HPV E6.

Band intensity was normalized to $\beta$-actin and scaled to the ETOH control. Bars = Relative Expression Level, Error bars show SEM, $n=3$. ${ }^{*} \mathrm{p}<0.05$. 


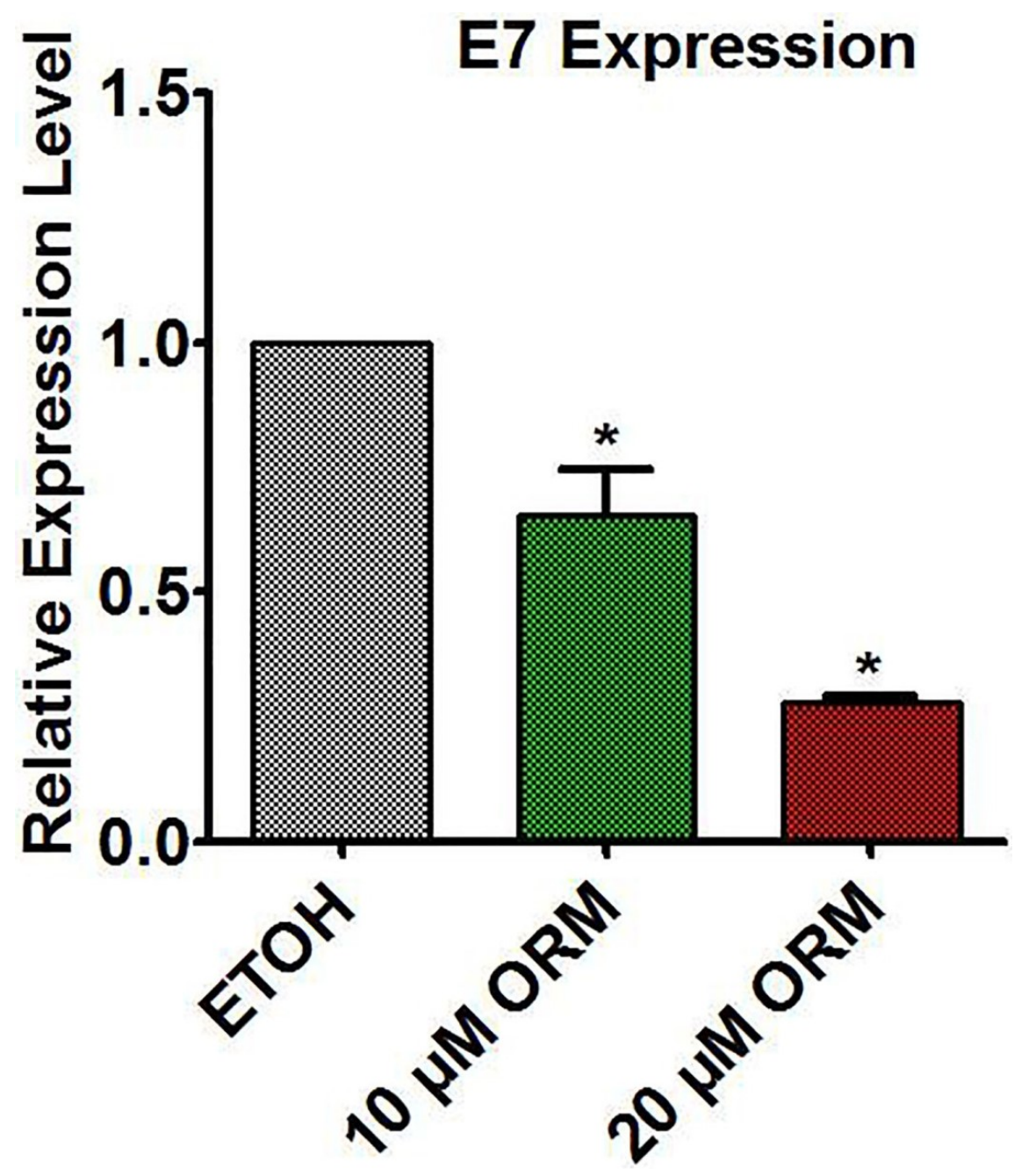

Figure 5-5. Densitometric quantitation of band intensity of HPV E7.

Band intensity was normalized to $\beta$-actin and scaled to the ETOH control. Bars $=$ Relative Expression Level, Error bars show SEM, $n=3 .{ }^{*} p<0.05$. 


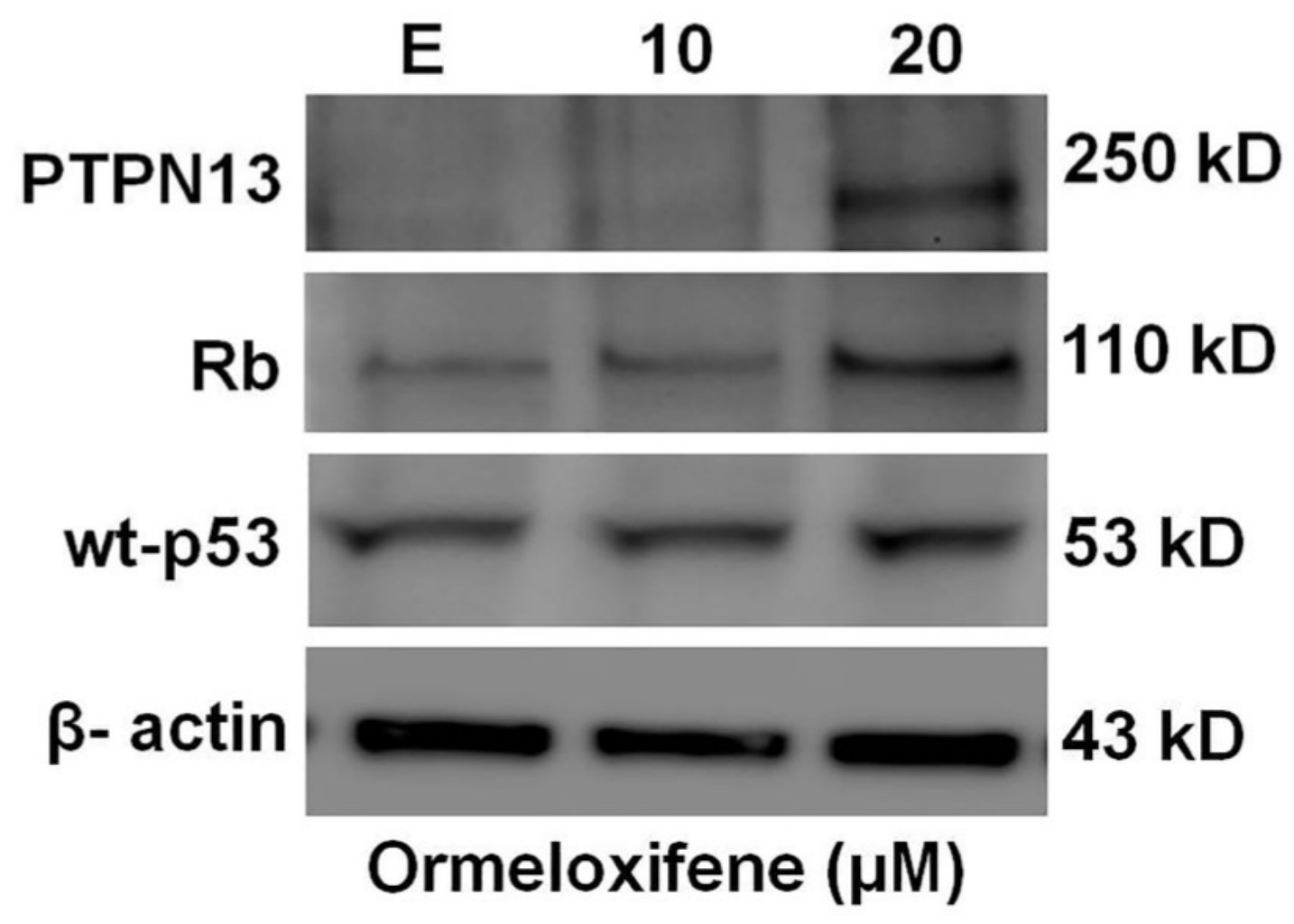

Figure 5-6. Ormeloxifene restored the expression levels of p53, Rb and PTPN13 tumor suppressor proteins.

Caski cells were treated with ormeloxifene for $24 \mathrm{hrs}$ and immunoblots were preformed to detect $\mathrm{p} 53, \mathrm{Rb}$ and PTPN13 proteins. $\beta$-actin was used as a loading control. 


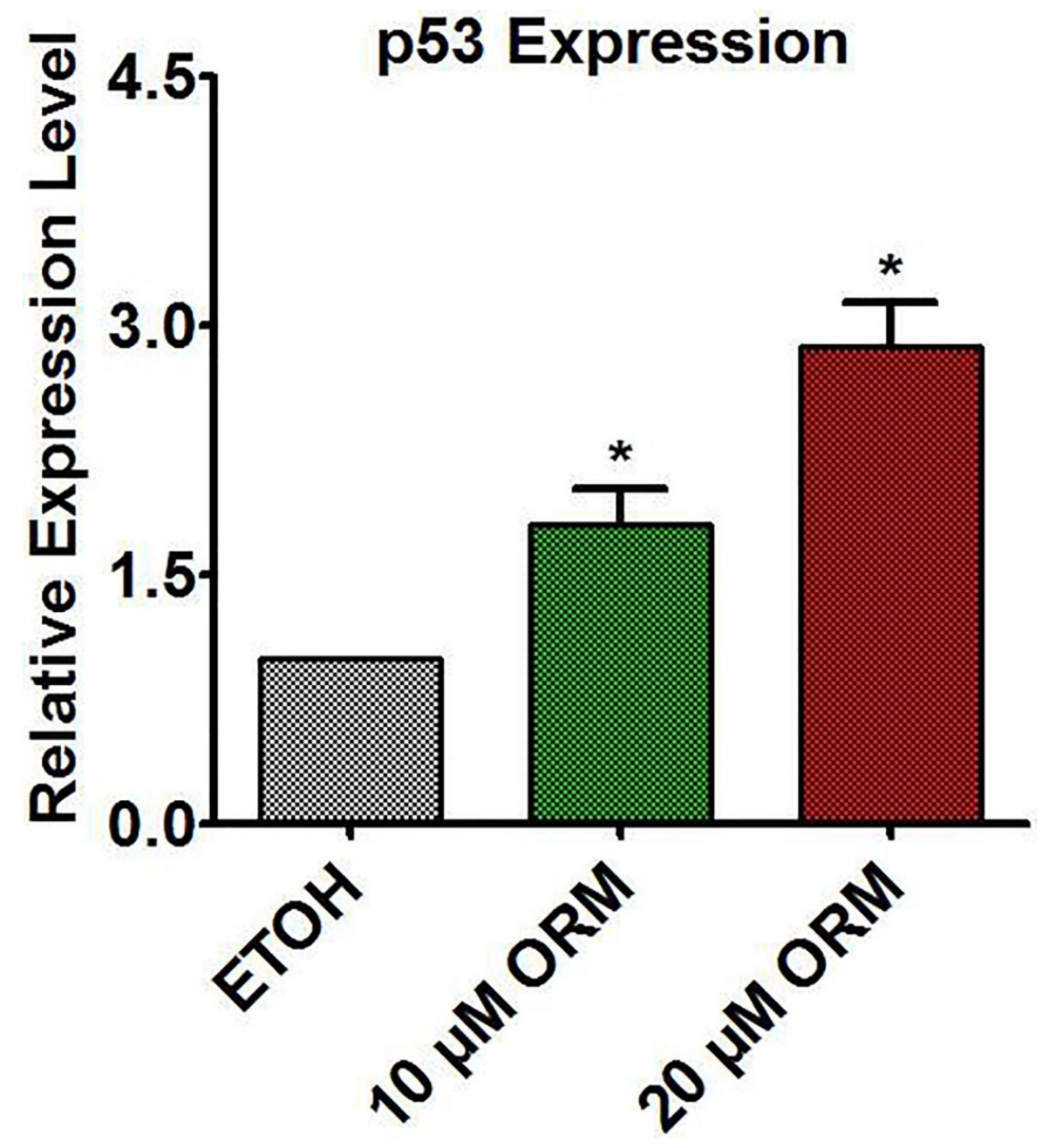

Figure 5-7. Densitometric quantitation of band intensity of p53.

Band intensity was normalized to $\beta$-actin and scaled to the ETOH control. Bars $=$ Relative Expression Level, Error bars show SEM, $n=3 .{ }^{*} \mathrm{p}<0.05$. 


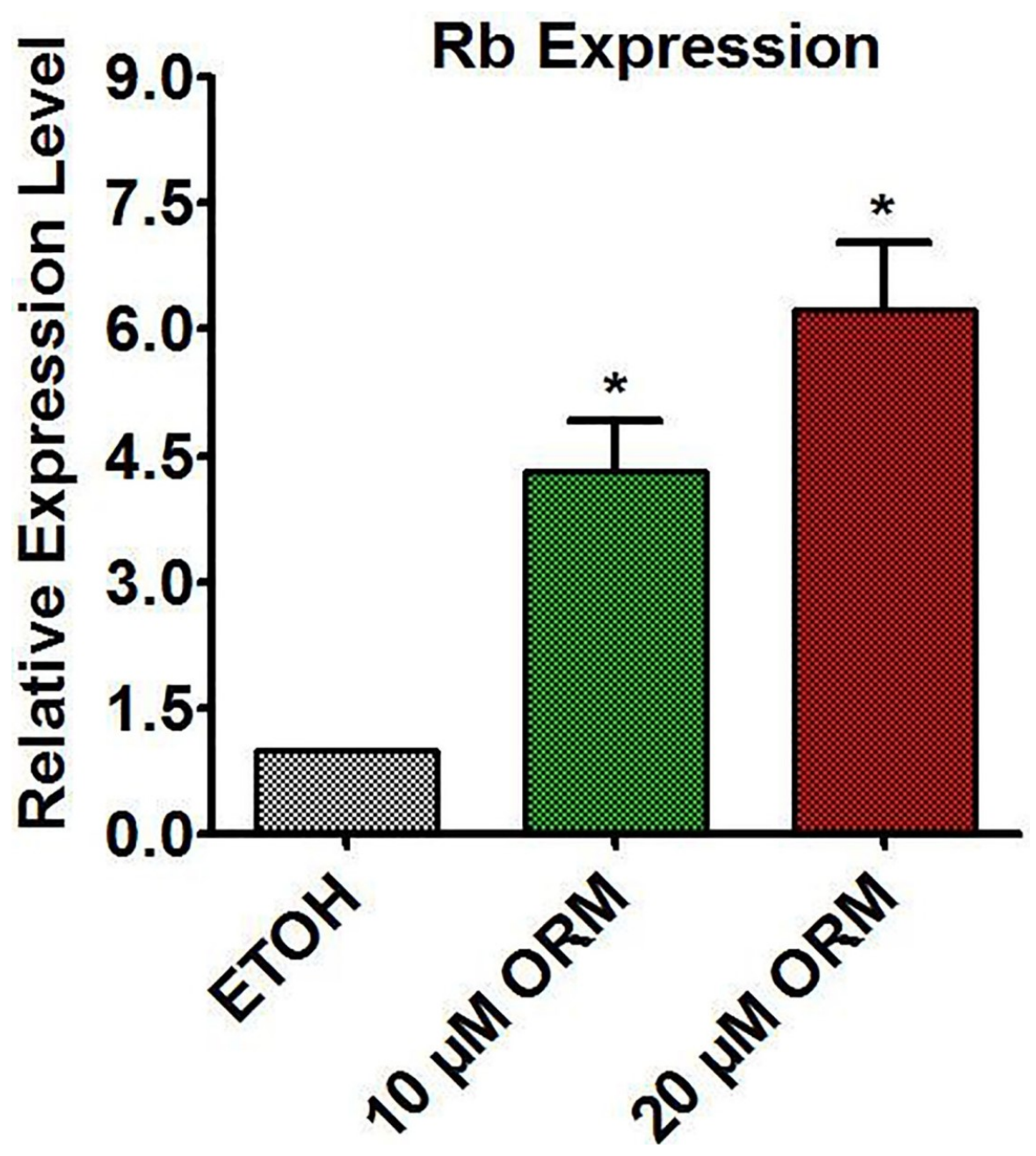

Figure 5-8. Densitometric quantitation of band intensity of $\mathbf{R b}$.

Band intensity was normalized to $\beta$-actin and scaled to the ETOH control. Bars $=$ Relative Expression Level, Error bars show SEM, $n=3$. ${ }^{*} \mathrm{p}<0.05$. 


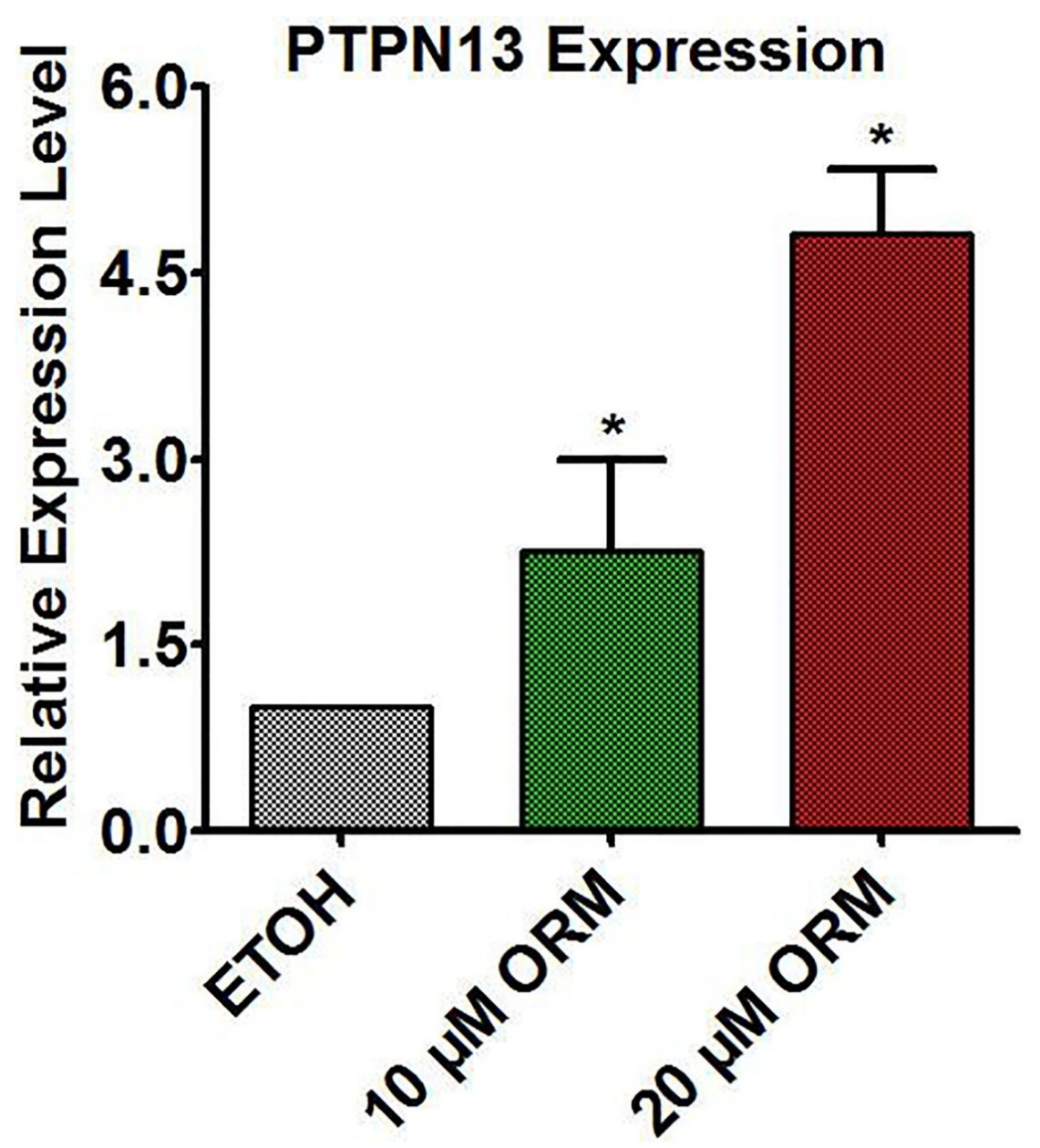

Figure 5-9. Densitometric quantitation of band intensity of PTPN13.

Band intensity was normalized to $\beta$-actin and scaled to the ETOH control. Bars $=$ Relative Expression Level, Error bars show SEM, $n=3 .{ }^{*} \mathrm{p}<0.05$. 


\title{
CHAPTER 6. IN VITRO EXAMINATION OF ORMELOXIFENE WITH RADIATION AS A COMBINATION THERAPY
}

\author{
Materials and Methods
}

\section{Cell Proliferation Assays}

In order to analyze the combinatorial effects of ormeloxifene with radiation we utilized Caski cells. Cells were seeded at 200,000 cells in $2 \mathrm{~mL}$ media per well of 6-well plates and allowed to adhere overnight. Next day the treatment was performed in two different conditions. The first set of cells was pre-treated with $10 \mu \mathrm{M}$ ormeloxifene for 24 hours and then next morning exposed to 4 Gy dose of radiation for another 24 hours. The second set of cells was co-treated with $10 \mu \mathrm{M}$ ormeloxifene and 4 Gy dose of radiation at the same time for next 24 hours. A Biological X-ray irradiator (Radiation Source, Alpharetta, GA) was used to irradiate the cells. After the indicated time cells were trypsized, washed with PBS and counted with coulter counter (Beckman coulter counter, Life Sciences). Experiment was done in triplicate.

\section{Colony Forming Assays}

Caski cervical cancer cells were seeded at 200 cells in $2 \mathrm{~mL} /$ well in 6 well plates and allowed to attach overnight. Following day, cells were pretreated with different concentrations of ormeloxifene $(2,4,6$ and $8 \mu \mathrm{M})$ for 6 hours. After 6 hours, cells were exposed to radiation at $4 \mathrm{~Gy}$ dose. Cells were then maintained for next 12-14 days. On the day of termination, cells were washed, fixed in cold methanol and stained with hematoxylin (Thermo Fisher). Visible colonies ( $\sim 50$ cells) were counted manually. Each experiment was done in triplicates and repeated 3 individual times.

\section{Statistical Methods}

Statistical analysis was determined by using an unpaired, two tailed student's ttest. The results were considered significant if $P<0.05$. All graphs were generated using GraphPad Prism5 software.

\section{Results}

Ormeloxifene treatment induced radio-sensitization in Caski cervical cancer cells. We performed short term and long term studies to analyze ormeloxifene's effect in radiosensitization in Caski cells. We observed that after 24 hours of radiation, number of live cells significantly decreased with both pretreatment (Figure 6-1 and Figure 6-2) and cotreatment (Figure 6-3 and Figure 6-4) of ormeloxifene when compared with radiation 

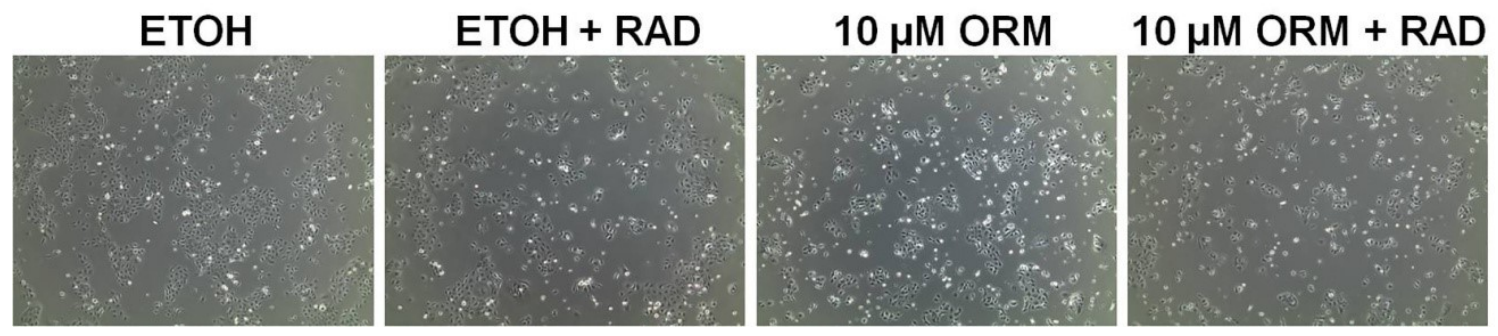

Figure 6-1. Caski cells were pretreated with ormeloxifene and exposed to radiation.

Combination treatment of ormeloxifene and radiation showed an inhibitory effect on cellular growth/ proliferation. Images were taken at 100X. 


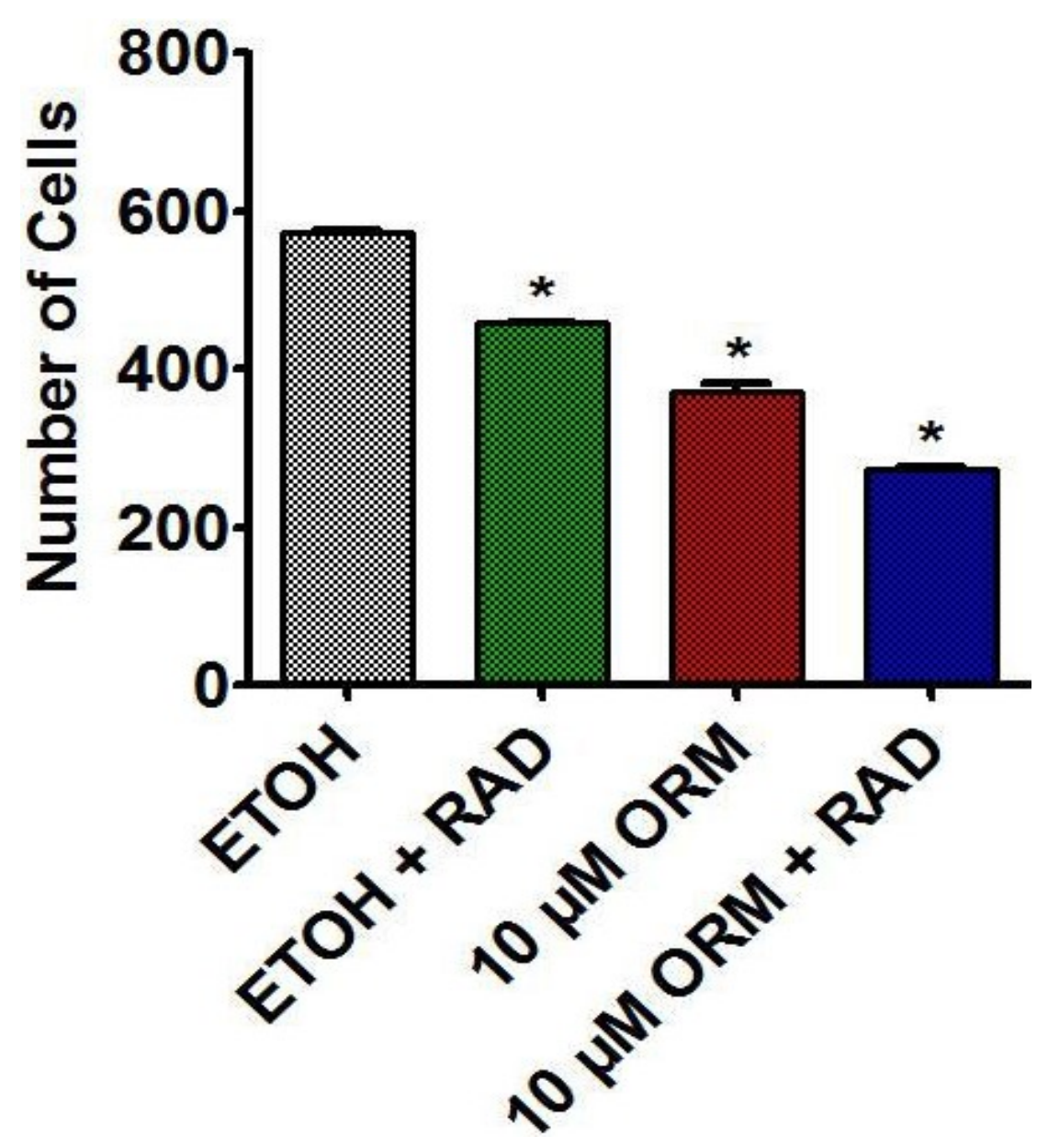

Figure 6-2. Caski cells were pretreated with ormeloxifene and exposed to radiation and cells were counted with Coulter counter.

Results were normalized to the ETOH control (for ormeloxifene) and to radiation and free ORM (for combination). Error bars show SEM, $n=3 .{ }^{*} p<0.05$. Combination treatment of ormeloxifene and radiation showed an inhibitory effect on cellular growth/ proliferation. 

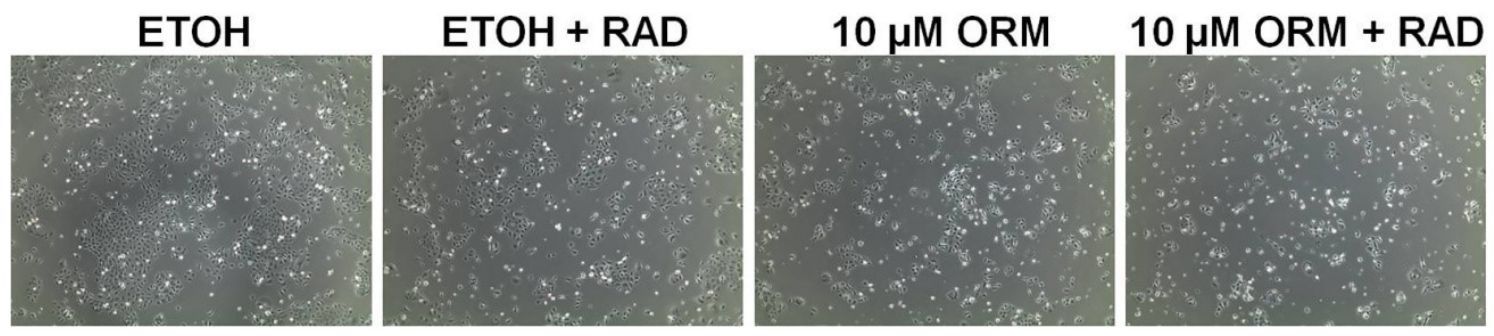

Figure 6-3. Caski cells were treated with ormeloxifene and exposed to radiation simultaneously.

Combination treatment of ormeloxifene and radiation showed an inhibitory effect on cellular growth/ proliferation. Images were taken at 100X. 


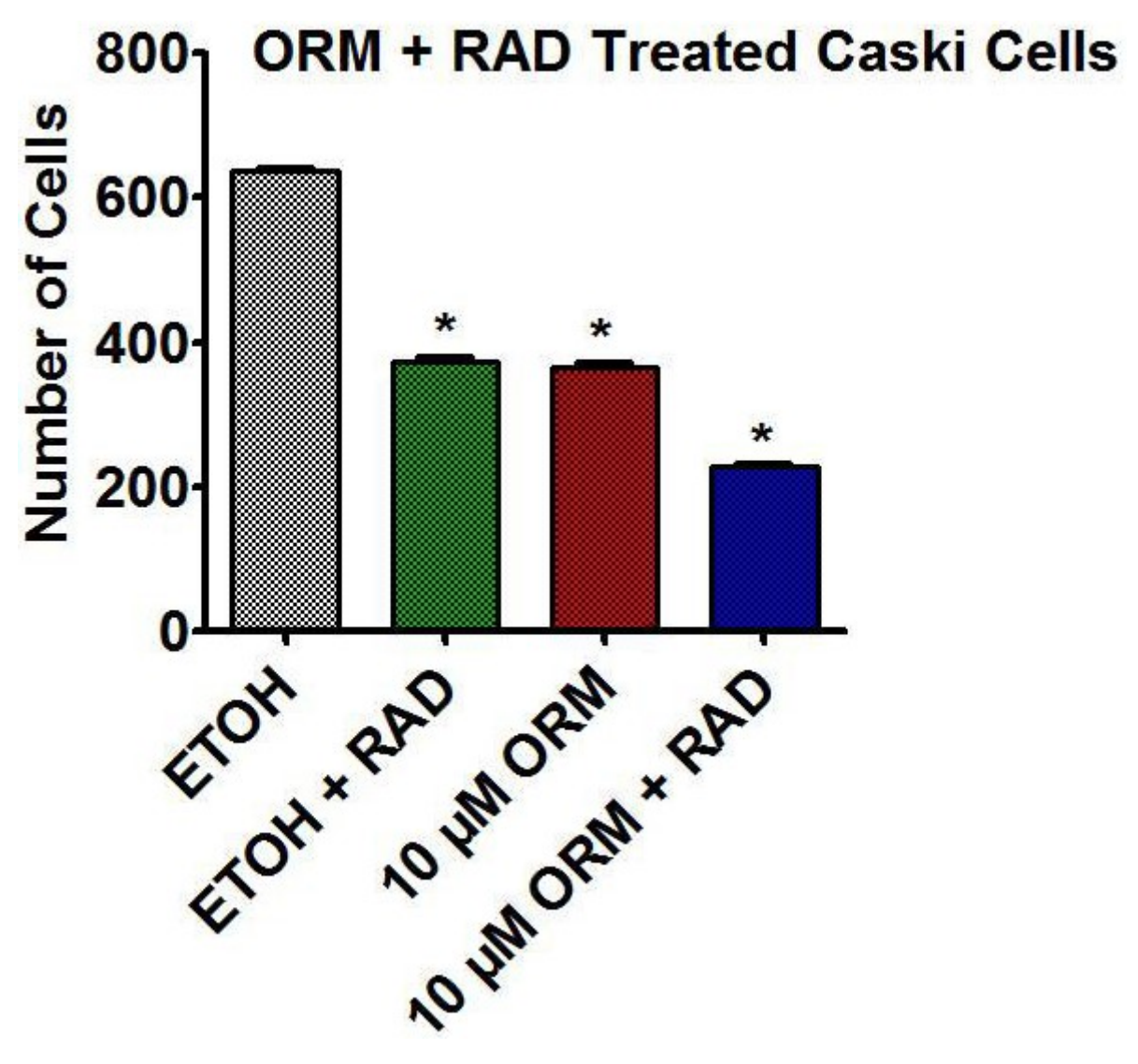

Figure 6-4. Caski Cells were treated with ormeloxifene and exposed to radiation simultaneously and cells were counted with Coulter counter.

Results were normalized to the ETOH control (for ormeloxifene) and to; radiation and free ORM (for combination). Error bars show SEM, $n=3$. ${ }^{*} \mathrm{p}<0.05$. Combination treatment of ormeloxifene and radiation showed an inhibitory effect on cellular growth/ proliferation. 
alone and ormeloxifene alone treatment groups. However, the co-treatment showed more inhibition of cellular growth than pretreatment. The results were consistent with long term pretreatment of ormeloxifene and significantly sensitized Caski cells to radiation as confirmed by decreased number of colonies when compared to radiation alone and ormeloxifene alone treated groups (Figure 6-5). The quantification of colonies is presented in Figure 6-6.

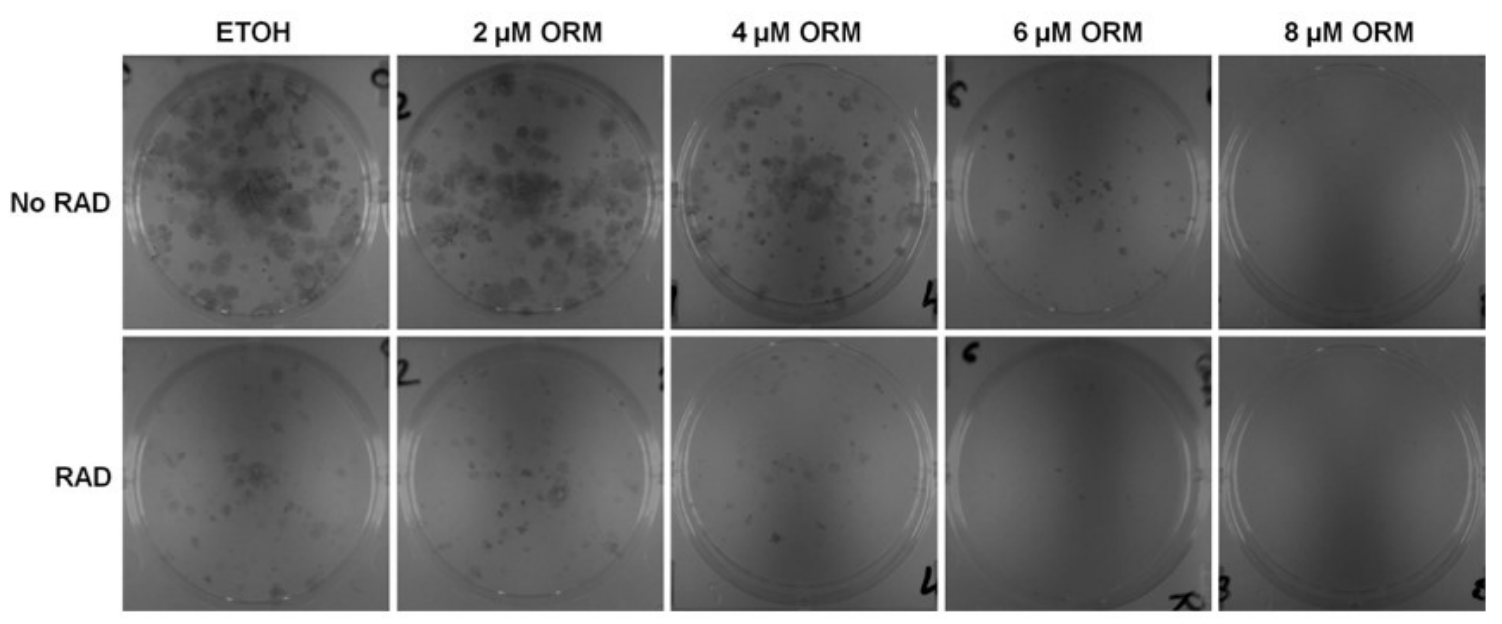

Figure 6-5. Combination treatment of ormeloxifene and radiation reduced the clonogenic potential of Caski cells.

Cells were pretreated with ormeloxifene and exposed to radiation. Cells were observed under phase contrast microscope and images were taken at $200 \mathrm{X}$. 


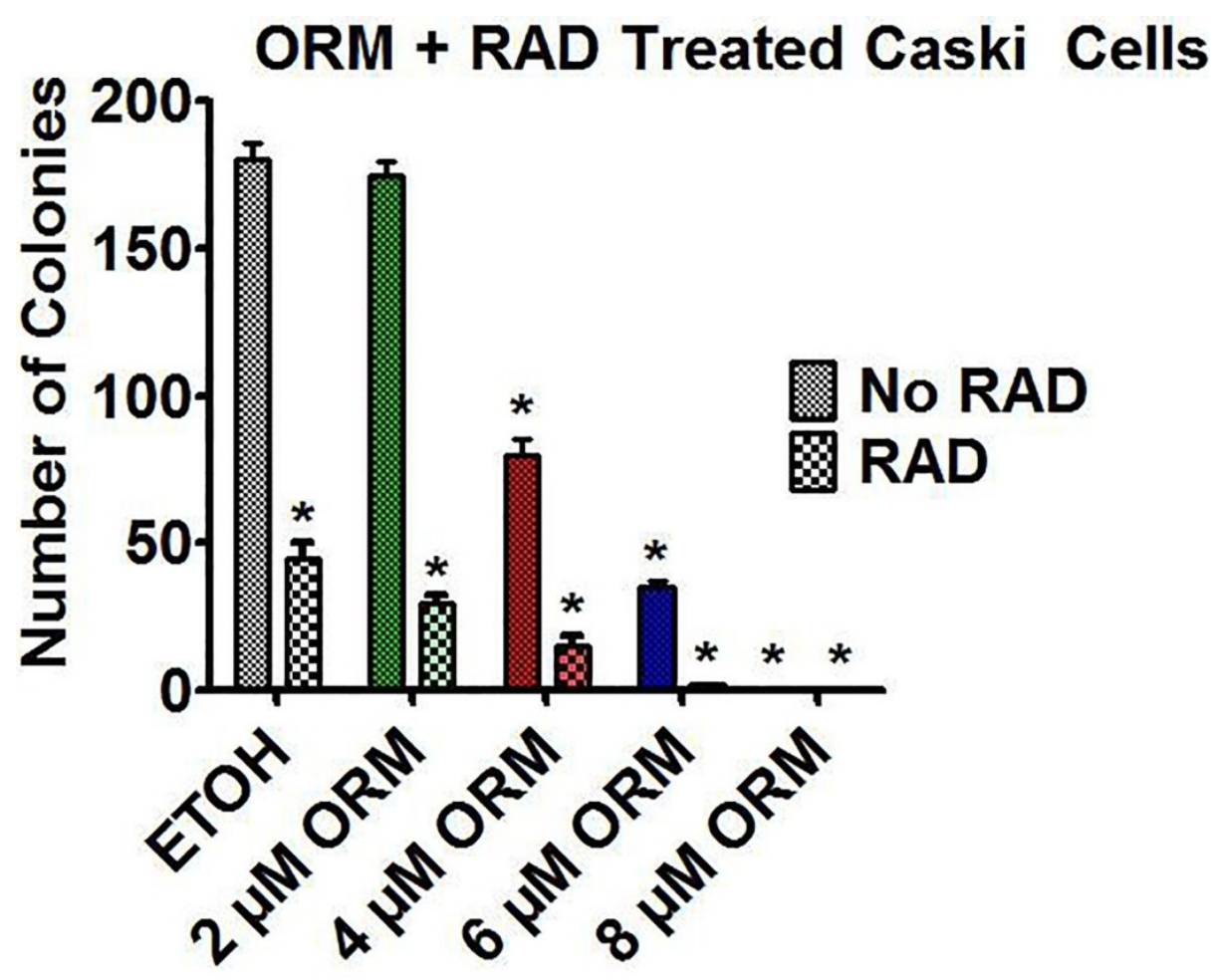

Figure 6-6. Bar graph showing that combination treatment of ormeloxifene and radiation reduced the clonogenic potential of Caski cells.

Cells were pretreated with ormeloxifene and exposed to radiation. Results were normalized to the ETOH control (for ormeloxifene) and to radiation and free ORM (for combination). Error bars show SEM, $\mathrm{n}=3 .{ }^{*} \mathrm{p}<0.05$. 


\title{
CHAPTER 7. DEVELOPMENT AND PHYSICOCHEMICAL CHARACTERIZATION OF ORMELOXIFENE LOADED PLGA NANOPARTICLES*
}

\author{
Materials and Methods
}

\section{Synthesis of PLGA-ORM NPs}

PLGA-ORM NPs were prepared by following a nano-precipitation technique $[176,177]$ with a modified protocol (Figure 7-1). The stable PLGA-ORM NP suspension was obtained using polymer stabilizers, poly(vinyl alcohol) (PVA) and poly(L-lysine) (PLL). Briefly, to $20 \mathrm{~mL}$ aqueous 1\% PVA solution, $90 \mathrm{mg}$ of PLGA and $20 \mathrm{mg}$ ORM were dissolved in 8-10 mL acetone that was added drop-wise using a $1 \mathrm{~mL}$ pipette over 10 min under a constant stirring on a magnetic stir plate at $500 \mathrm{rpm}$. This process leads to a milky-white suspension. This suspension was left overnight at room temperature in the chemical fume hood under stirring condition, allowing for complete evaporation of the acetone. Then, to this suspension, $10 \mathrm{mg}$ PLL in $5 \mathrm{~mL}$ water was added and stirred at 500 rpm for $6 \mathrm{hr}$. The resulted PLGA-ORM NPs in suspension were purified and recovered by ultracentrifugation at 20,000 rpm for $2 \mathrm{hr}$ at $4^{\circ} \mathrm{C}$, three times, using a Rotor 30.50 on an Avanti J-30I Centrifuge (Beckman Coulter, Fullerton, CA), followed by re-suspension in ultra-purified water and sonication on ice for $1 \mathrm{~min}$ (using a probe sonicator). Then the supernatant containing PLGA-ORM NPs was transferred to a sterile cryo-vial, frozen at $80^{\circ} \mathrm{C}$ for $2 \mathrm{hr}$, and immediately lyophilized for 2-3 days using the Labconco Freeze Dry System $\left(-48^{\circ} \mathrm{C}, 133 \times 10^{-3} \mathrm{mBar}\right.$; Labconco, Kansas City, MO). The lyophilized vials were stored in a $4^{\circ} \mathrm{C}$ cold room for further in vitro and in vivo use. This formulation was named PLGA-ORM 20. Similarly, PLGA-ORM formulations with 5, 10, 15, and $25 \mathrm{mg}$ ORM were prepared and termed as PLGA-ORM 5, PLGA-ORM 10, PLGA-ORM 15, and PLGA-ORM 25, respectively. Additionally, parent PLGA NPs were also prepared without ORM that served as a control for all in vitro and in vivo experiments.

\section{PLGA-ORM NPs Characterization}

\section{Particle Size}

PLGA-ORM NPs were characterized for the surface morphology and size of particles using a JEOL-1210 transmission electron microscope (TEM) (JEOL Ltd., Tokyo, Japan) operating at $60 \mathrm{kV}$. For this, $50 \mu \mathrm{L}$ suspension of $1 \mathrm{mg} / \mathrm{mL}$ PLGA-ORM NPs was carefully dispersed on 200 mesh formvar-coated copper TEM-grid (grid size:

\footnotetext{
* Adapted with permission. Khan, S., et al., Nanoparticle formulation of ormeloxifene for pancreatic cancer. Biomaterials, 2015. 53: p. 731-743.
} 


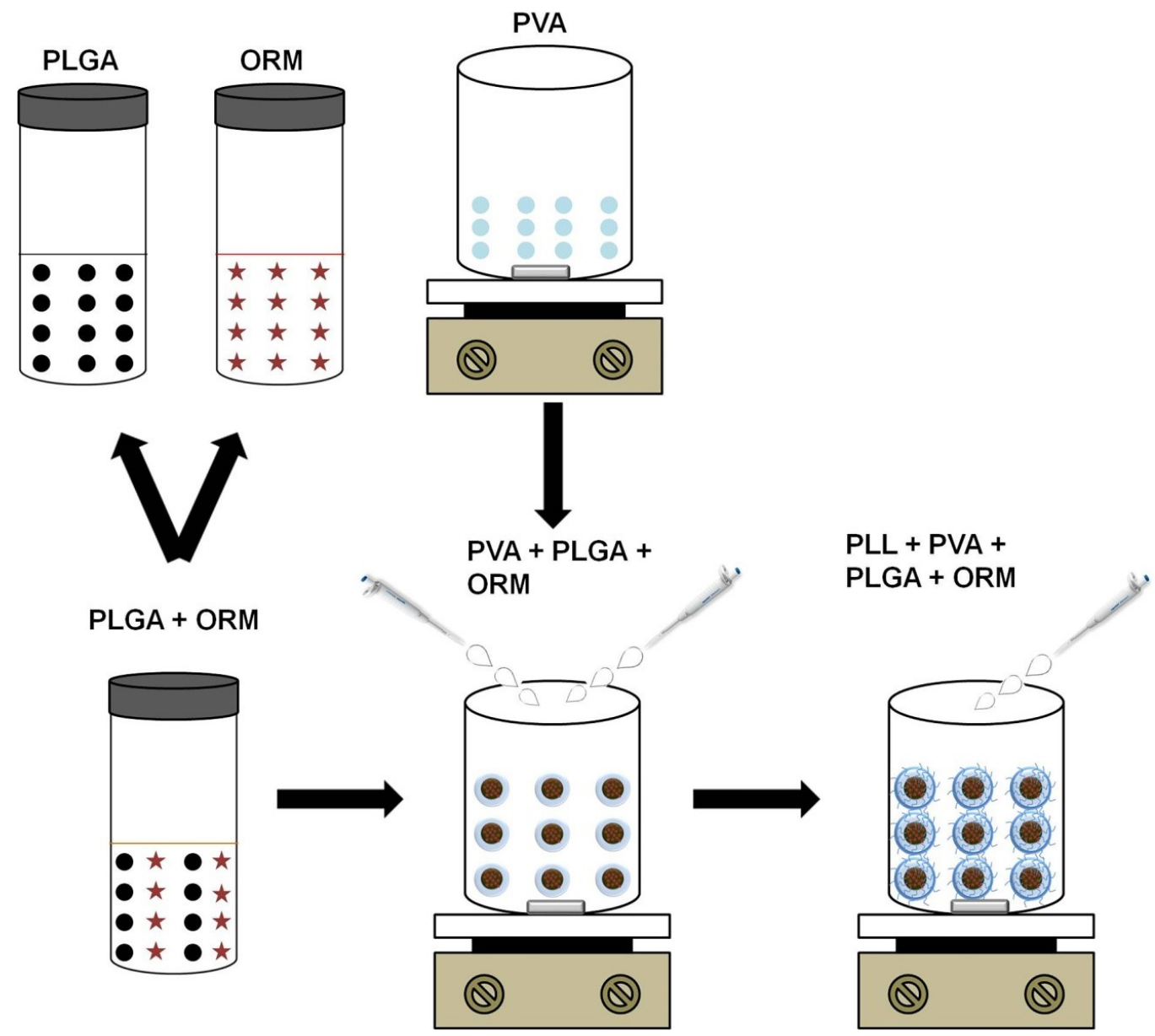

Figure 7-1. Diagram showing preparation method (nano-precipitation) of PLGAORM nanoformulation. 
$97 \mu \mathrm{m})($ Ted Pella, Inc., Redding, CA), followed by staining with $2 \% \mathrm{w} / \mathrm{v}$ of uranyl acetate solution. The excess solution on the grid was removed by air drying. Then, particles on the TEM-grid were imaged under TEM. We also used a dynamic light scattering system to confirm particle size.

\section{Drug Loading}

To determine ORM loading, freshly prepared PLGA-ORM NPs were centrifuged three times at 20,000 rpm for $2 \mathrm{hr}$ at $4^{\circ} \mathrm{C}$ using Avanti J-30I Centrifuge, followed by resuspension in ultra-purified water and sonication on ice for $1 \mathrm{~min}$. The supernatant was removed, the pellet was re-suspended, lyophilized, and ORM from pellet was extracted for 2 days with $1 \mathrm{~mL}$ of acetonitrile. The concentration of ORM in the extract was analyzed using an UltiMate high-performance liquid chromatography (HPLC) (Dionex Corporation) equipped with UltiMate 3000 injector, RS variable wavelength detector, and an Acclaim polar advantage column of $3 \mu \mathrm{m} 120 \AA(4.6 \times 150 \mathrm{~mm})$. The mobile-phase consisted of a mixture of $1 \%$ citric acid:acetonitrile $(40: 60, \mathrm{v} / \mathrm{v}) .50 \mu \mathrm{L}$ of the extracted samples were injected using an auto injector (Model 508, Beckmann Instruments) and peaks were analyzed using a UV detector at $279 \mathrm{~nm}$. The retention time was observed at $\sim 18-20 \mathrm{~min}$ [191]. A linear calibration curve in the range of 1 to $10 \mu \mathrm{g} / \mathrm{mL}$ was obtained at the same working condition for ORM. From this data, the ORM loading content was calculated as follows:

\section{Fourier Transform Infra-Red}

FT-IR spectra of PLGA-ORM NPs were obtained using a Fourier Transform infra-red (FT-IR) microscope (Smiths Detection, Danbury, CT). The spectra data, 4,000 $750 \mathrm{~cm}^{-1}$, was acquired at a scanning speed of $\mathrm{cm}^{-1}$ for 32 scans by placing lyophilized PLGA-ORM NPs powder on the attenuated total reflection objective. The final data is reported as an average data of 32 scans.

\section{Thermal Analysis}

Thermal analysis of PLGA-ORM NPs was carried out using differential scanning calorimetry (DSC) and thermo-gravimetric analyzer (TGA) to investigate the physical status and thermal profile. Both DSC and TGA profiles were accomplished on a Q50 TGA (TA Instruments, New Castle, DE) under dry nitrogen atmosphere (a flow rate of $10 \mathrm{~mL} / \mathrm{min}$ ) from $25^{\circ} \mathrm{C}$ to $700^{\circ} \mathrm{C}$ at the heating rate of $10^{\circ} \mathrm{C} / \mathrm{min}$.

\section{In Vitro Drug Release (Dialysis Bag Method)}

Dialysis membrane bag based drug release method [1] (Figure 7-2) was employed to evaluate release of ormeloxifene (ORM) from PLGA-ORM 20 nanoformulation in PBS containing 0.1\% (wt/vol) Tween-80 (PBS-T). In detail, $1 \mathrm{~mL}$ of $180 \mu \mathrm{g}$ ORM/mL PLGA-ORM 20 suspension was placed in a dialysis membrane bag (molecular weight cut off size, 12 kDa, Sigma-Aldrich Co., St. Louis, MO) which was 


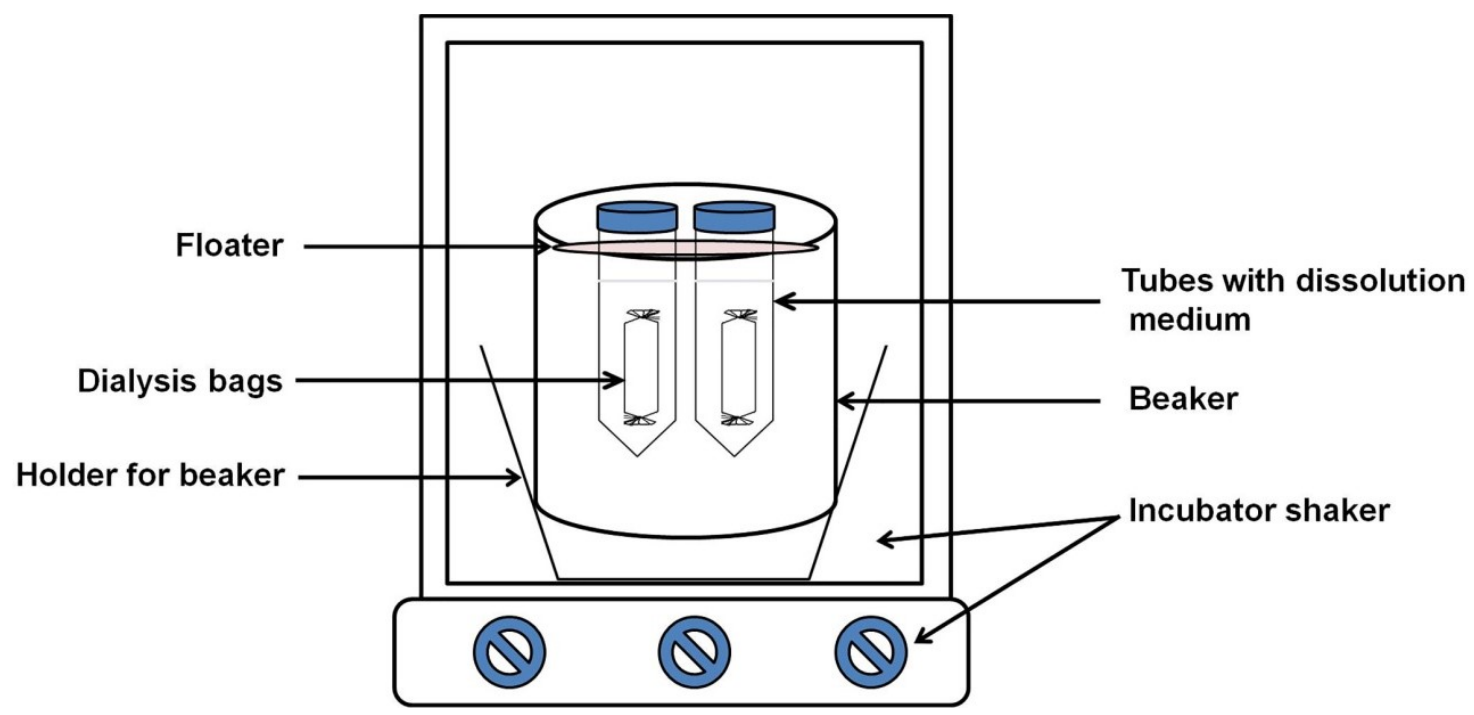

Figure 7-2. Representation of in vitro drug release in house system. 
immersed in $3 \mathrm{~mL}$ PBS-T, pH 7.4 in a tube at $37^{\circ} \mathrm{C}$ and rotated at $100 \mathrm{rpm}$ on an orbital shaker. The released drug from PLGA-ORM 20 into PBS-T was estimated at indicated time points [1 hr, $3 \mathrm{hrs}, 6 \mathrm{hrs}$, day 1 ( $24 \mathrm{hrs})$, day 3 ( $72 \mathrm{hrs})$, day 5 (120 hrs), and day 7 (168 hrs)] using acetonitrile for drug extraction. The released ORM was analyzed by Waters HPLC Alliance system equipped with an e2695 separations module and a Waters 2998 photo-diode array (PDA) detector (Milford, MA, USA). Samples were analyzed using a Waters HPLC system which has an auto injector and the instrument was operated by use of Empower ${ }^{\circledR}$ software (Milford, MA, USA). Components were separated on a Waters C18 reversed- phase column (Milford, MA, USA) with $300 \mathrm{~mm} \times 4.6 \mathrm{~mm}$ dimensions and $5 \mu \mathrm{m}$ particle size. A linear calibration curve in the range of 0.1 to 10 $\mu \mathrm{g} / \mathrm{mL}$ was obtained as identical to drug release process and calculated the released drug from PLGA-ORM formulation. The data is represented as percent release. (WHSA)

\section{Colloidal Stability of Nanoparticles in Whole Human Serum Albumin}

Before testing nanoparticles in vivo, it is important to confirm in vitro stability of nanoparticles with human serum. If nanoparticles are not compatible with serum, they aggregate and result in higher absorbance value. To study human serum compatibility of our formulation, we utilized Spectrophotometer absorption method as due to the turbidity of the serum, dynamic light scattering method is not very useful for authentication. For this experiment, PLGA-ORM was finally prepared at $1 \mathrm{mg} / \mathrm{mL}$ concentration; from this stock solution we incubated $100 \mu \mathrm{L}$ of this novel formulation with $100 \mu \mathrm{L}$ of whole human serum albumin at $37^{\circ} \mathrm{C}$ for different time points from $0 \mathrm{hr}$ to $48 \mathrm{hrs}$. At each time point, absorbance was measured at $560 \mathrm{~nm}$ utilizing Cytation 3 imaging multi microplate reader (BioTek).

\section{Statistical Methods}

Statistical analysis was determined by using an unpaired, two tailed student's ttest. The results were considered significant if $P<0.05$. All graphs were generated using GraphPad Prism5 software and Statistical Package for the Social Sciences, version 11.5 (SPSS Inc., Chicago, IL).

\section{Results}

The primary objectives of this study were to improve the anti-cancer activity of ORM, using a nanoparticle formulation (Figure 7-3) [192], and to examine its efficacy in human cervical cancer cell line and xenograft mouse models. The motive to make an ORM nanoformulation is that; nanoparticles (NPs) are known to preferentially reach and accumulate in tumor tissue(s) due to leaky vasculature by the Enhanced Permeation and Retention (EPR) effect [193, 194]. For such phenomenon, a better example is Abraxane ${ }^{\circledR}$, which has been widely used in the clinic for the treatment of various types of cancers, 


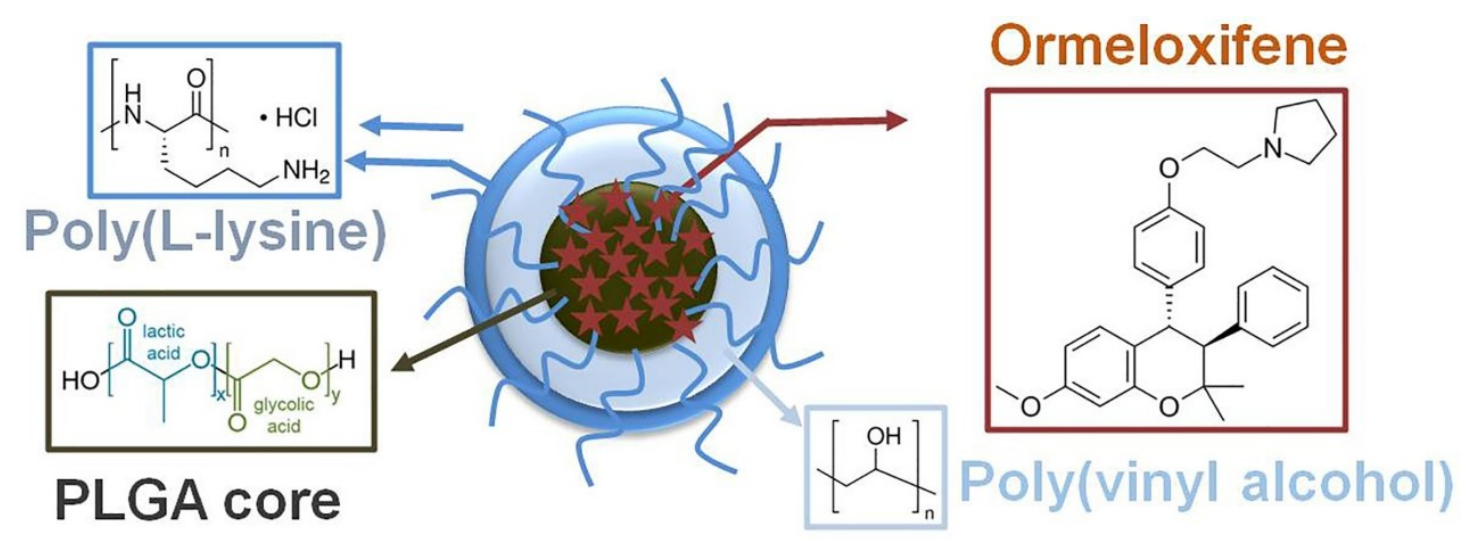

Figure 7-3. Schematic of PLGA-ORM NP formulations.

Reprinted with permission. Khan, S., et al., Nanoparticle formulation of ormeloxifene for pancreatic cancer. Biomaterials, 2015. 53: p. 731-743. 
including pancreatic cancer. This confirms that the nanodrug formulation(s) may have superior outcome over traditional chemotherapy in clinical oncology. Therefore, we have generated a PLGA-based ORM nanoparticle formulation, PLGA-ORM NPs. The selection of the PLGA NP-based formulation to deliver ORM is due to the fact that the PLGA co-polymer has shown promising results in in vitro, in vivo, pre-clinical, and human studies (for example, BIND-014, a docetaxel PLGA NP formulation). Based on these facts, we have engineered an optimized PLGA-ORM NP formulation, composed of a PLGA core that is subsequently coated with poly(vinyl alcohol) (PVA) and poly(1lysine) (PLL) for efficient delivery and targeting of ORM to cancer cells. This formulation (Figure 7-3), has several unique properties: (a) the PLGA core is capable of loading and releasing ORM in sustained manner, more importantly, it was approved by US Food and Drug Administration, (b) PVA, a widely used stabilizer for most of the polymer NP formulation(s), supports stability of formulation over 6 month(s) and avoids non-specific adsorption of human serum proteins in in vivo condition, (c) PLL promotes cellular internalization and is less toxic compared to other polycationic polymers, and (d) amine functional groups on NPs (PLL) are useful for antibody conjugation through a PEG-linker, notably, the N-Hydroxysuccinimide (NHS) group for targeting tumor/cancer cells.

\section{Characterization of PLGA-ORM NPs}

PLGA and PLGA-ORM NP formulations (PLGA-ORM 5, PLGA-ORM 10, PLGA-ORM 15, PLGA-ORM 20, and PLGA-ORM 25) were successfully prepared by increasing amounts of ORM in the composition (0 to $25 \mathrm{mg}$ ). Drug loading was assessed by HPLC method that indicated all the nanoformulations resulted in ORM encapsulation (> 80-90\% encapsulation efficiency). Based upon loading analysis, we selected PLGAORM 20 formulation for all our further cellular work. All formulations exhibit homogeneous spherical shapes and smooth surfaces without cracks (Figure 7-4, Figure 7-5, Figure 7-6, Figure 7-7, Figure 7-8 and Figure 7-9) [192]. The mean particle size of PLGA or PLGA-ORM NPs was found to be $30.8 \pm 1.5 \mathrm{~nm}$ (PLGA NPs), $68.4 \pm 1.5 \mathrm{~nm}$ (PLGA-ORM 5), $70.8 \pm 4.5 \mathrm{~nm}$ (PLGA-ORM 10), $87.3 \pm 1.5 \mathrm{~nm}$ (PLGA-ORM 15), $101.4 \pm 1.5 \mathrm{~nm}$ (PLGA-ORM 20), and $175.2 \pm 1.5 \mathrm{~nm}$ (PLGA-ORM 25). The size of PLGA-ORM NP formulations was mostly between $50 \mathrm{~nm}$ to $250 \mathrm{~nm}$ and was narrowly distributed in each formulation. (Figure 7-10) [192]. We also measured particle size using DLS method; data illustrated a particle size under $280 \mathrm{~nm}$ for all formulations (Figure 7-11). It was noticed that the formulation particle size increased when drug loading used for the particle preparation increased. However, all these formulations were small enough in size and suitable for tumor specific accumulation via the EPR effect [195]. To confirm the ORM existence in PLGA-ORM NP formulations, FT-IR (Figure 7-12), DSC (Figure 7-13), and TGA (Figure 7-14) studies were conducted [192]. In the FT-IR spectrum of PLGA NPs (Figure 7-12, navy blue line), the intense peaks were found at $1741 \mathrm{~cm}^{-1}, 1181 \mathrm{~cm}^{-1}$, and $1010 \mathrm{~cm}^{-1}$ due to $\mathrm{C}=\mathrm{O}$ stretching of ester, $\mathrm{C}-\mathrm{O}$ stretching of ester, and glycosidic $(\mathrm{C}-\mathrm{O}-\mathrm{C} / \mathrm{C}-\mathrm{C} / \mathrm{C}-\mathrm{O})$ stretch vibrations. Because ORM has similar major functional groups in its structures (Figure 7-12, black line), after 


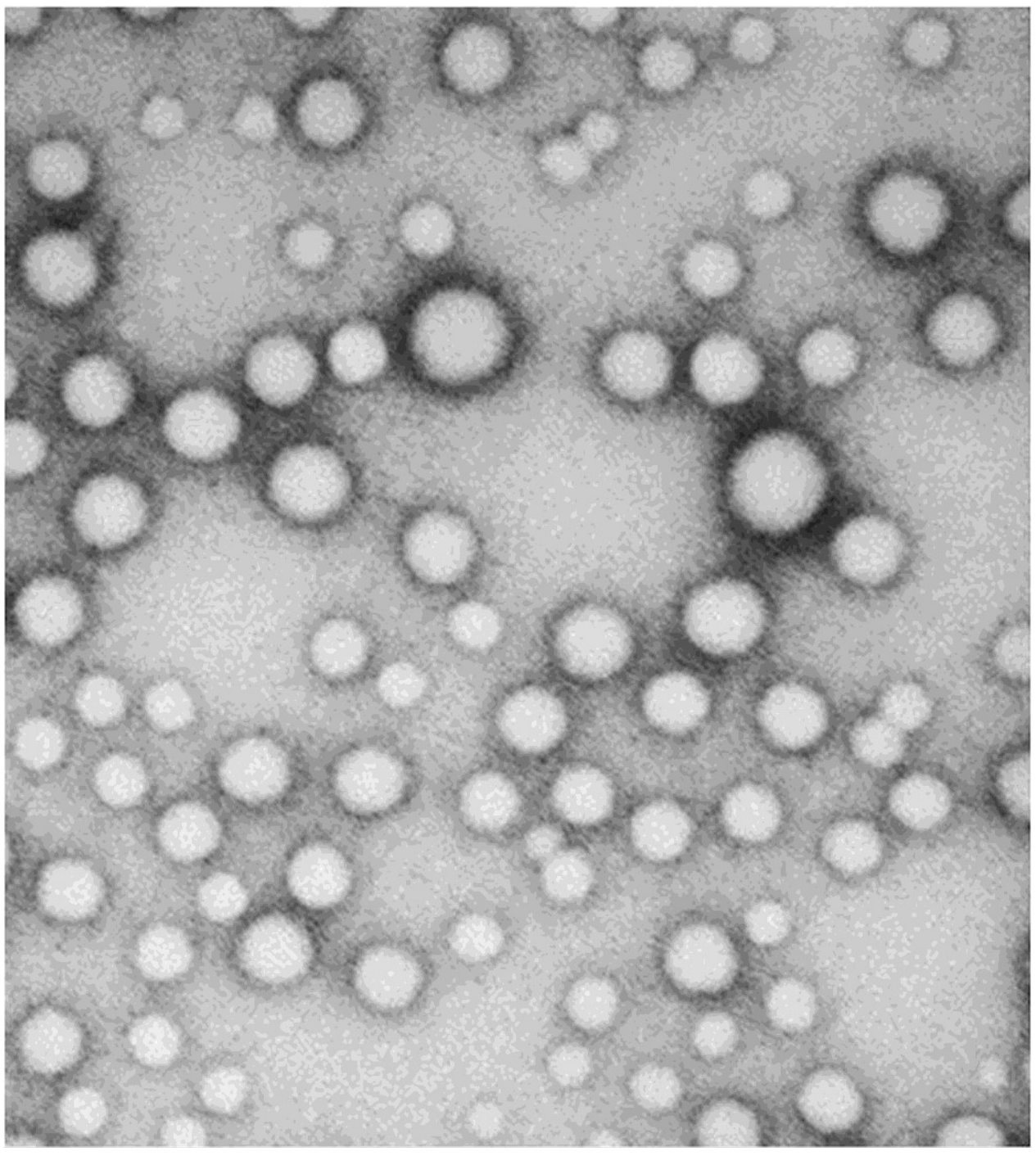

Figure 7-4. Representative TEM images of PLGA alone nanoparticles and Scale bars on TEM images equal $200 \mathrm{~nm}$.

Reprinted with permission. Khan, S., et al., Nanoparticle formulation of ormeloxifene for pancreatic cancer. Biomaterials, 2015. 53: p. 731-743. 


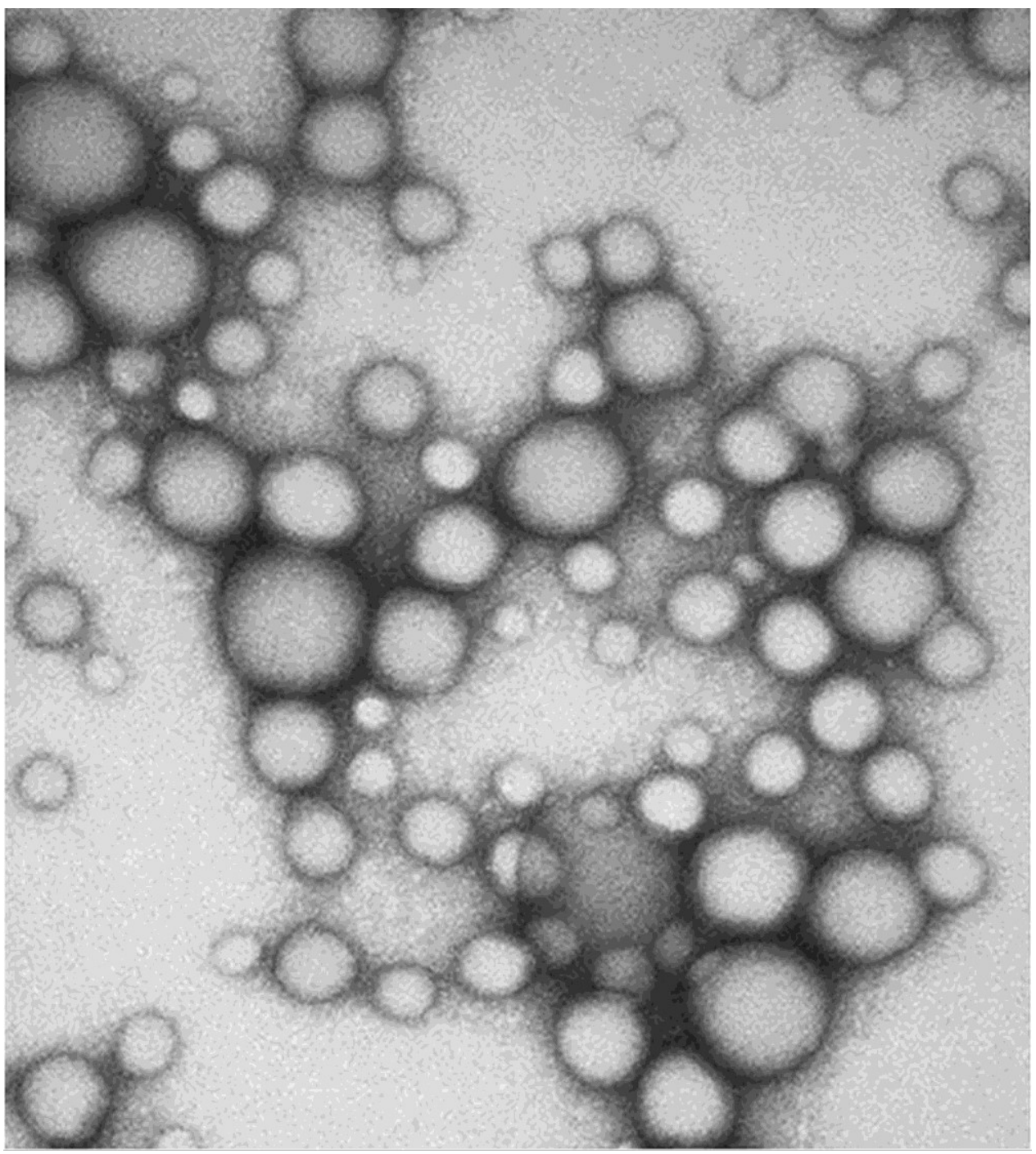

Figure 7-5. Representative TEM images of PLGA-ORM 5 nanoparticles and Scale bars on TEM images equal $200 \mathrm{~nm}$.

Reprinted with permission. Khan, S., et al., Nanoparticle formulation of ormeloxifene for pancreatic cancer. Biomaterials, 2015. 53: p. 731-743. 


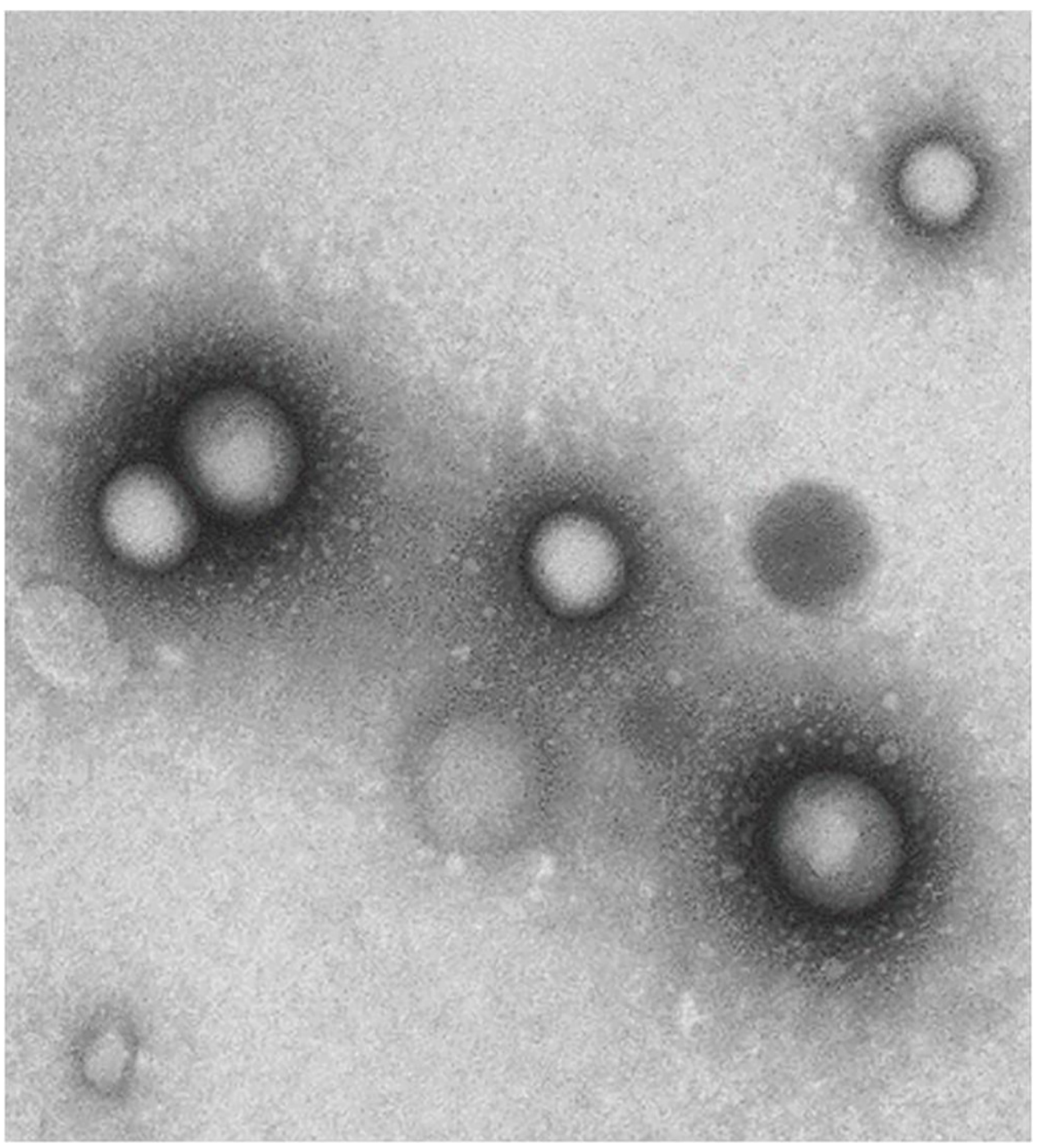

Figure 7-6. Representative TEM images of PLGA-ORM 10 nanoparticles and Scale bars on TEM images equal $200 \mathrm{~nm}$.

Reprinted with permission. Khan, S., et al., Nanoparticle formulation of ormeloxifene for pancreatic cancer. Biomaterials, 2015. 53: p. 731-743. 


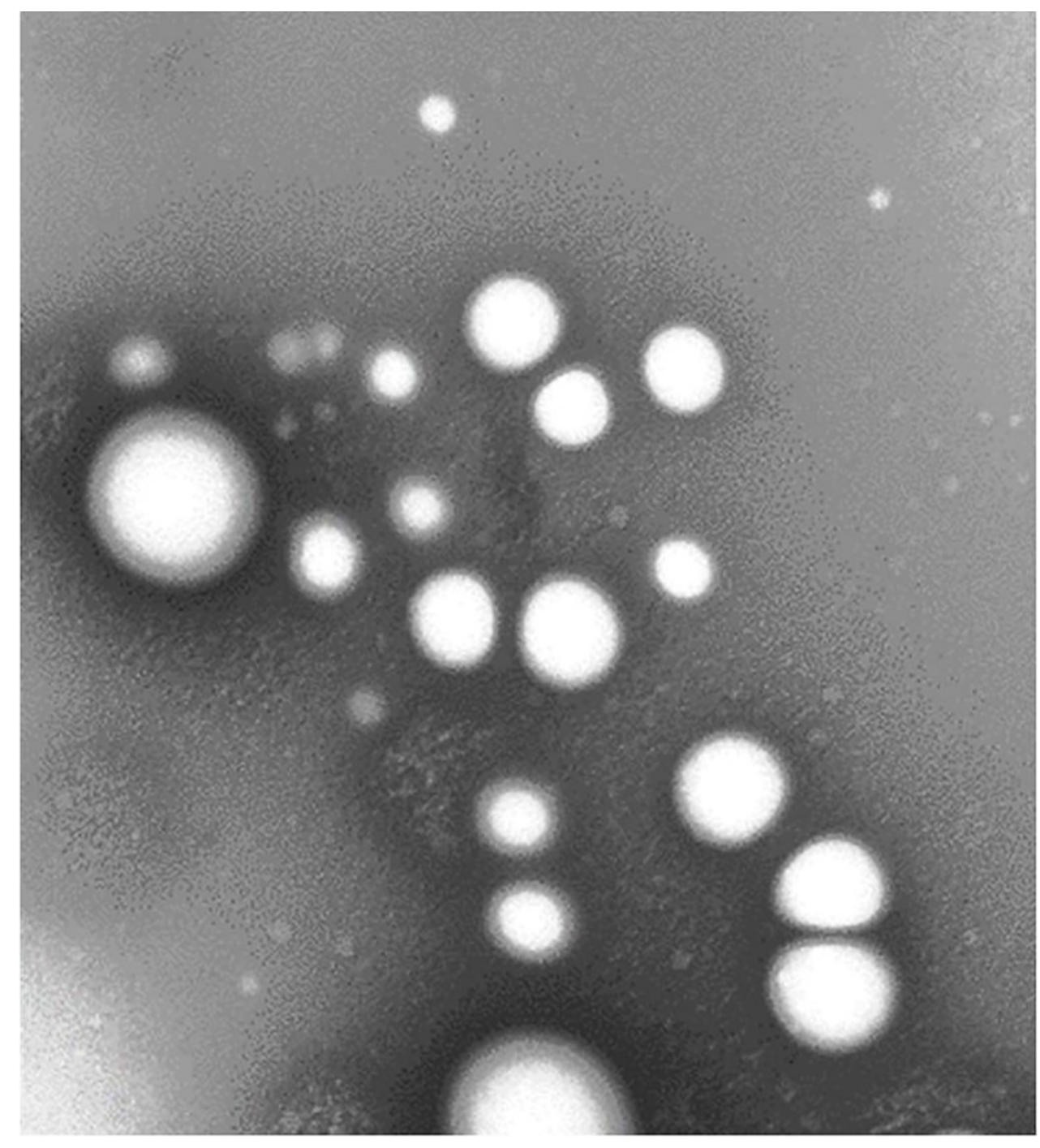

Figure 7-7. Representative TEM images of PLGA-ORM 15 nanoparticles and Scale bars on TEM images equal $200 \mathrm{~nm}$.

Reprinted with permission. Khan, S., et al., Nanoparticle formulation of ormeloxifene for pancreatic cancer. Biomaterials, 2015. 53: p. 731-743. 


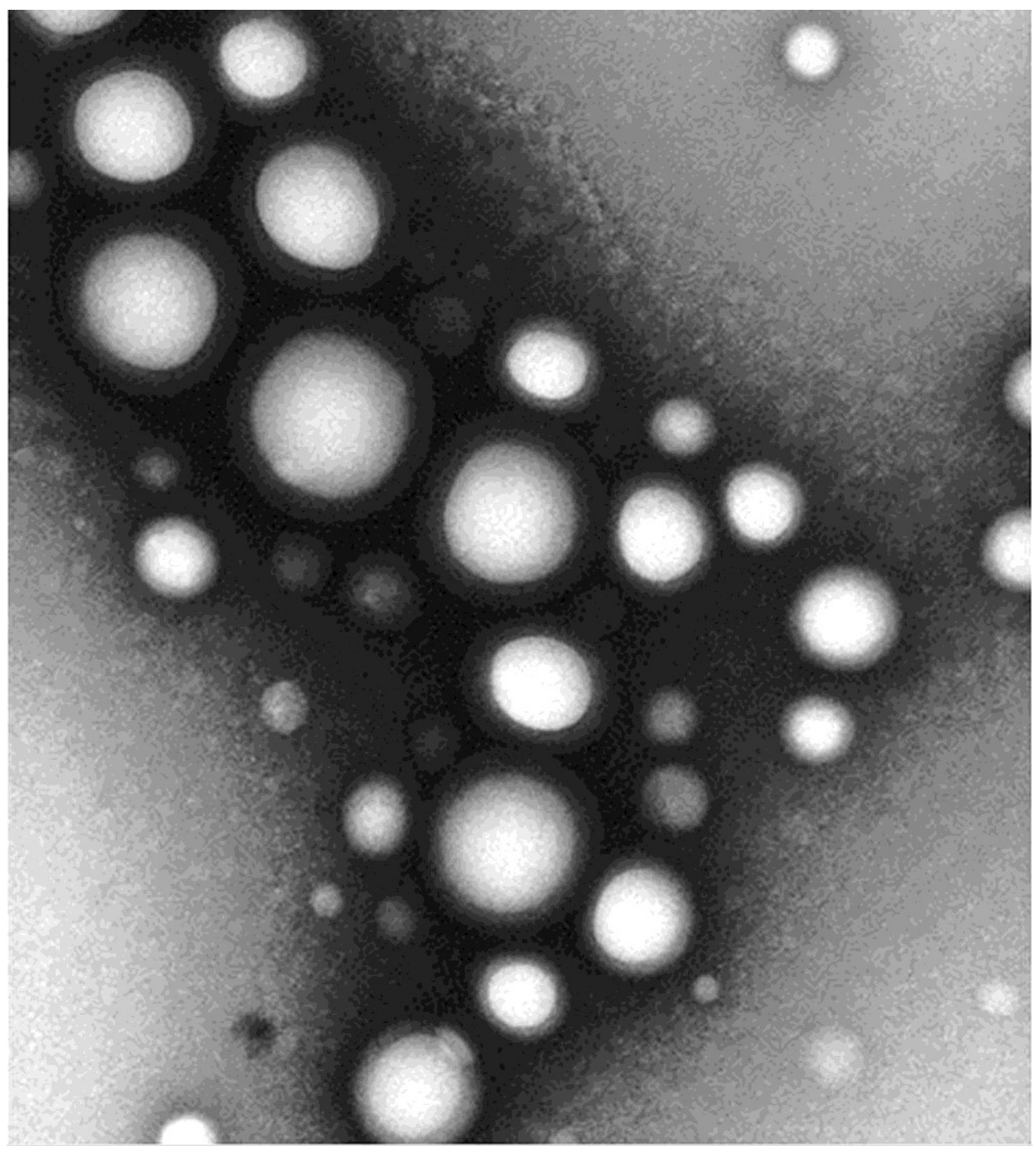

Figure 7-8. Representative TEM images of PLGA-ORM 20 nanoparticles and Scale bars on TEM images equal $200 \mathrm{~nm}$.

Reprinted with permission. Khan, S., et al., Nanoparticle formulation of ormeloxifene for pancreatic cancer. Biomaterials, 2015. 53: p. 731-743. 


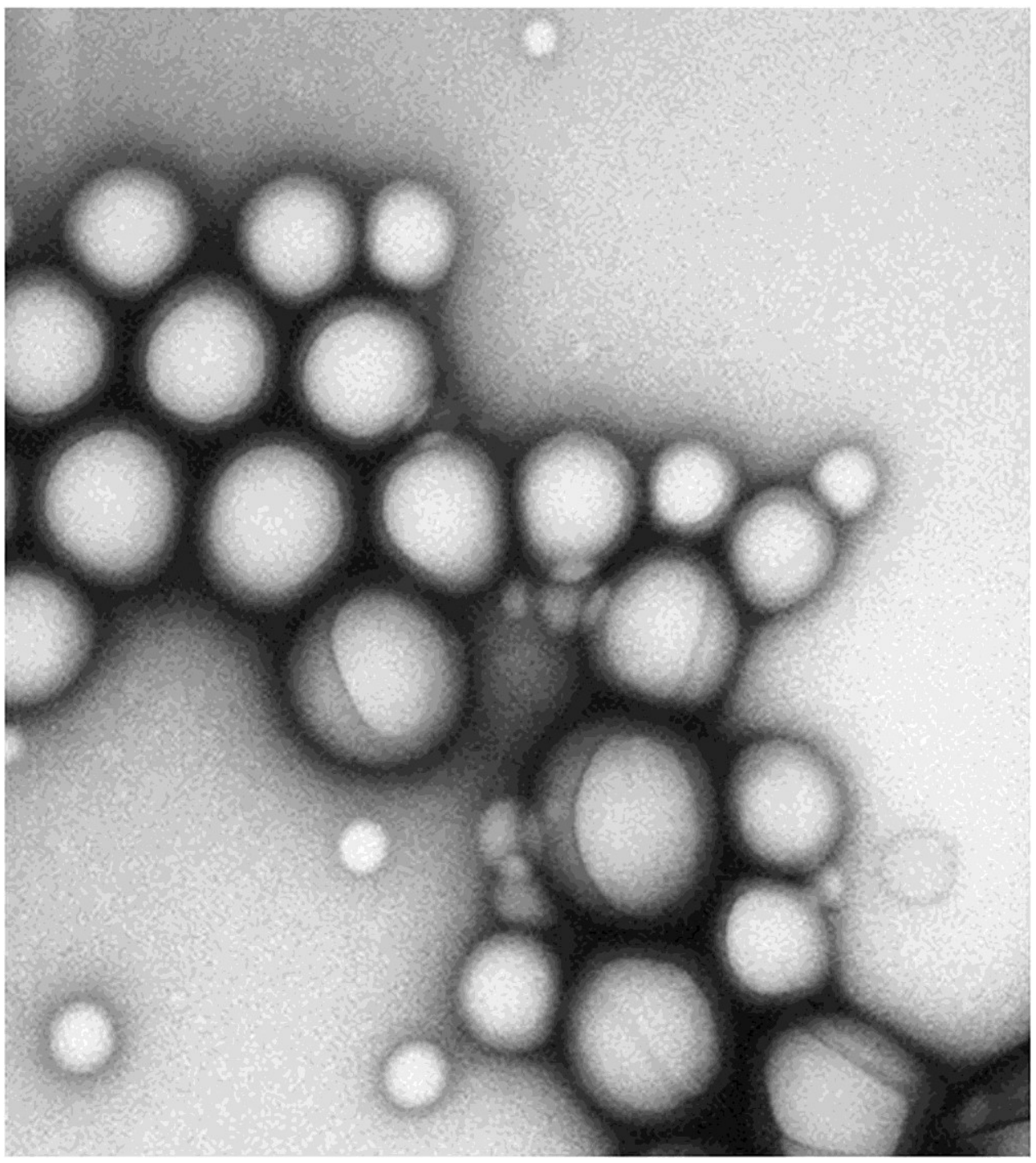

Figure 7-9. Representative TEM images of PLGA-ORM 25 nanoparticles and Scale bars on TEM images equal $200 \mathrm{~nm}$.

Reprinted with permission. Khan, S., et al., Nanoparticle formulation of ormeloxifene for pancreatic cancer. Biomaterials, 2015. 53: p. 731-743. 


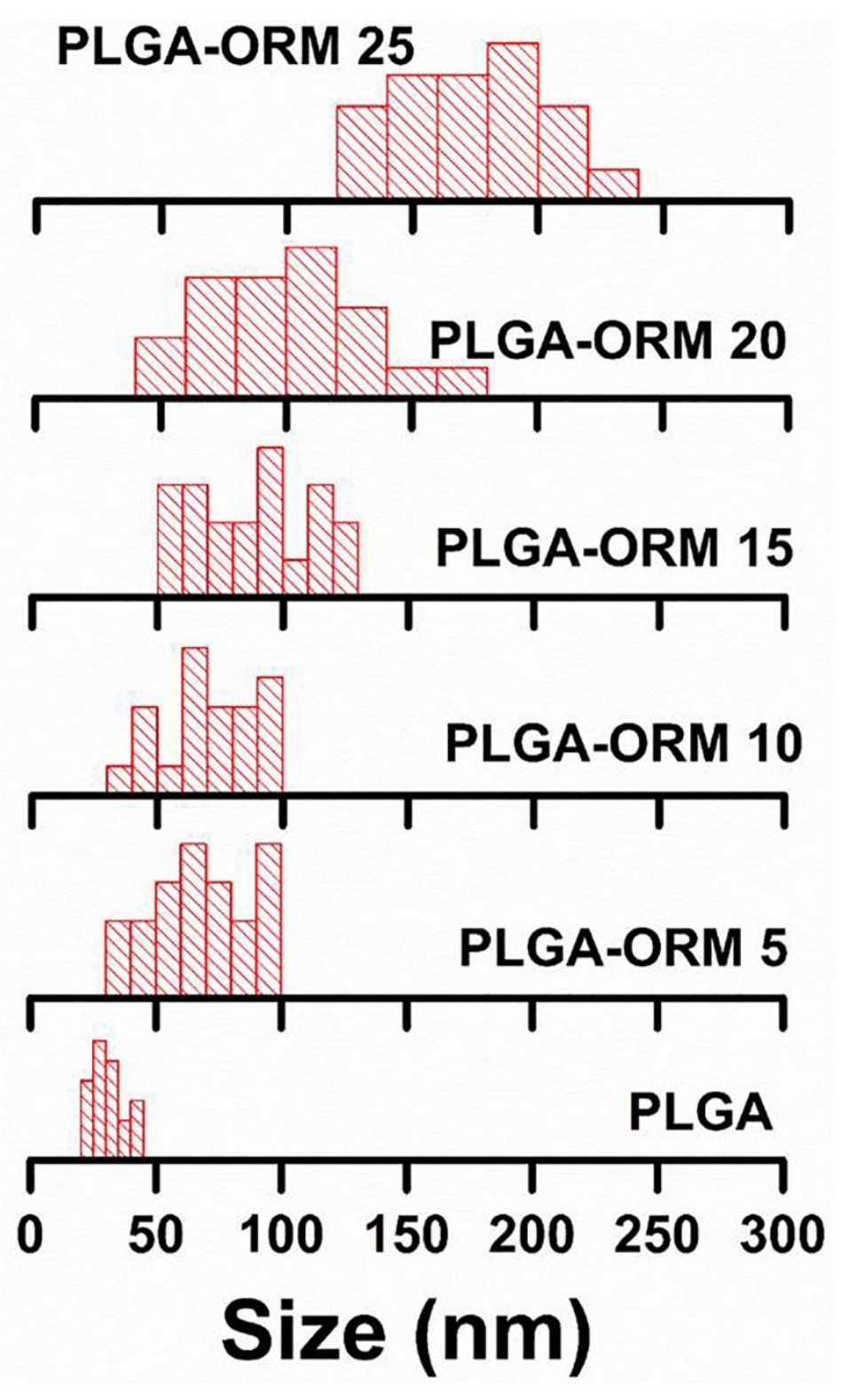

Figure 7-10. Evaluation of nanoparticle size from TEM images using ImageJ software, data represents an average of at least $\mathbf{2 0}$ particles in two different fields of view in TEM images.

Reprinted with permission. Khan, S., et al., Nanoparticle formulation of ormeloxifene for pancreatic cancer. Biomaterials, 2015. 53: p. 731-743. 


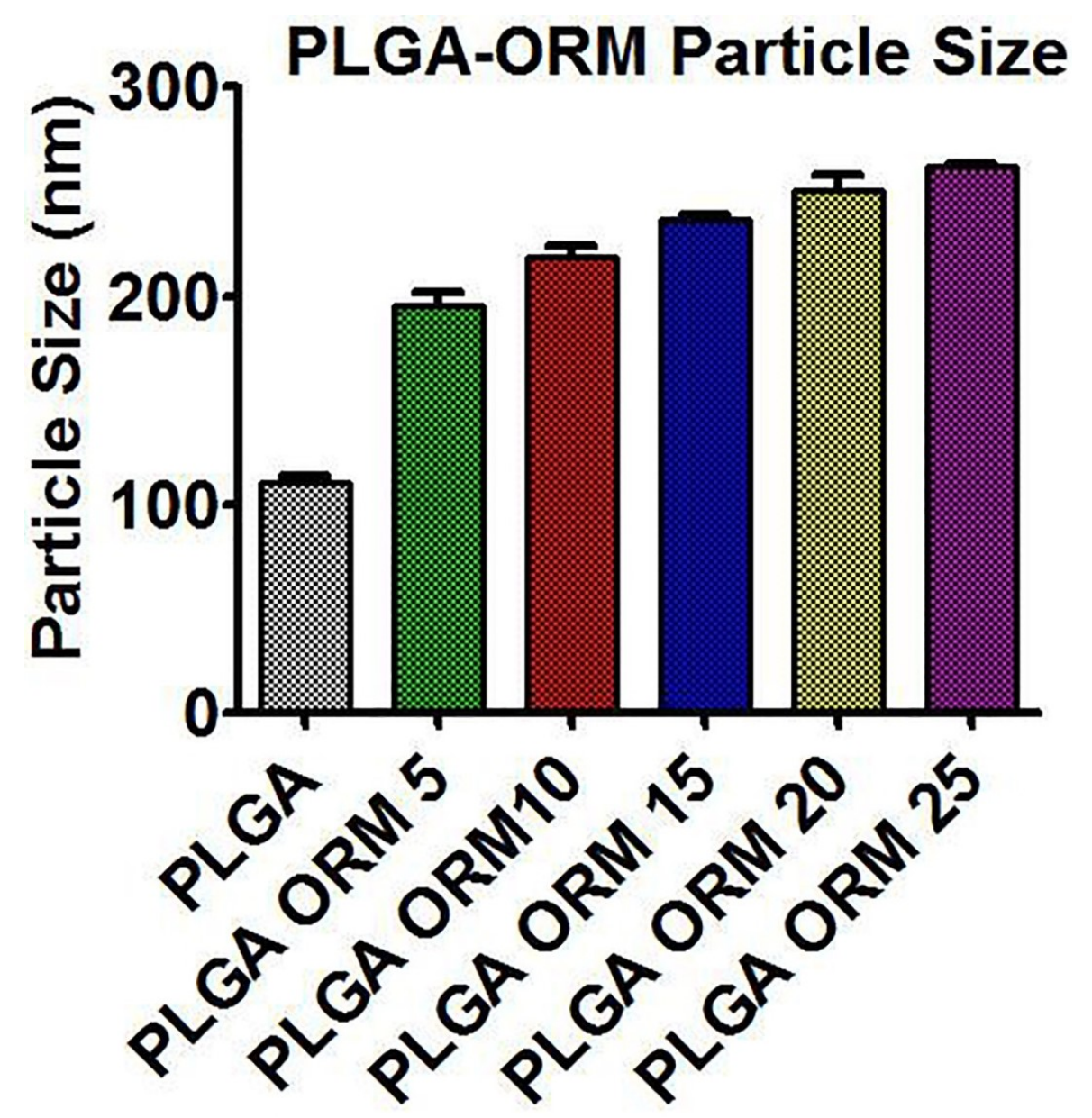

Figure 7-11. PLGA-ORM particle size representation using DLS system. 


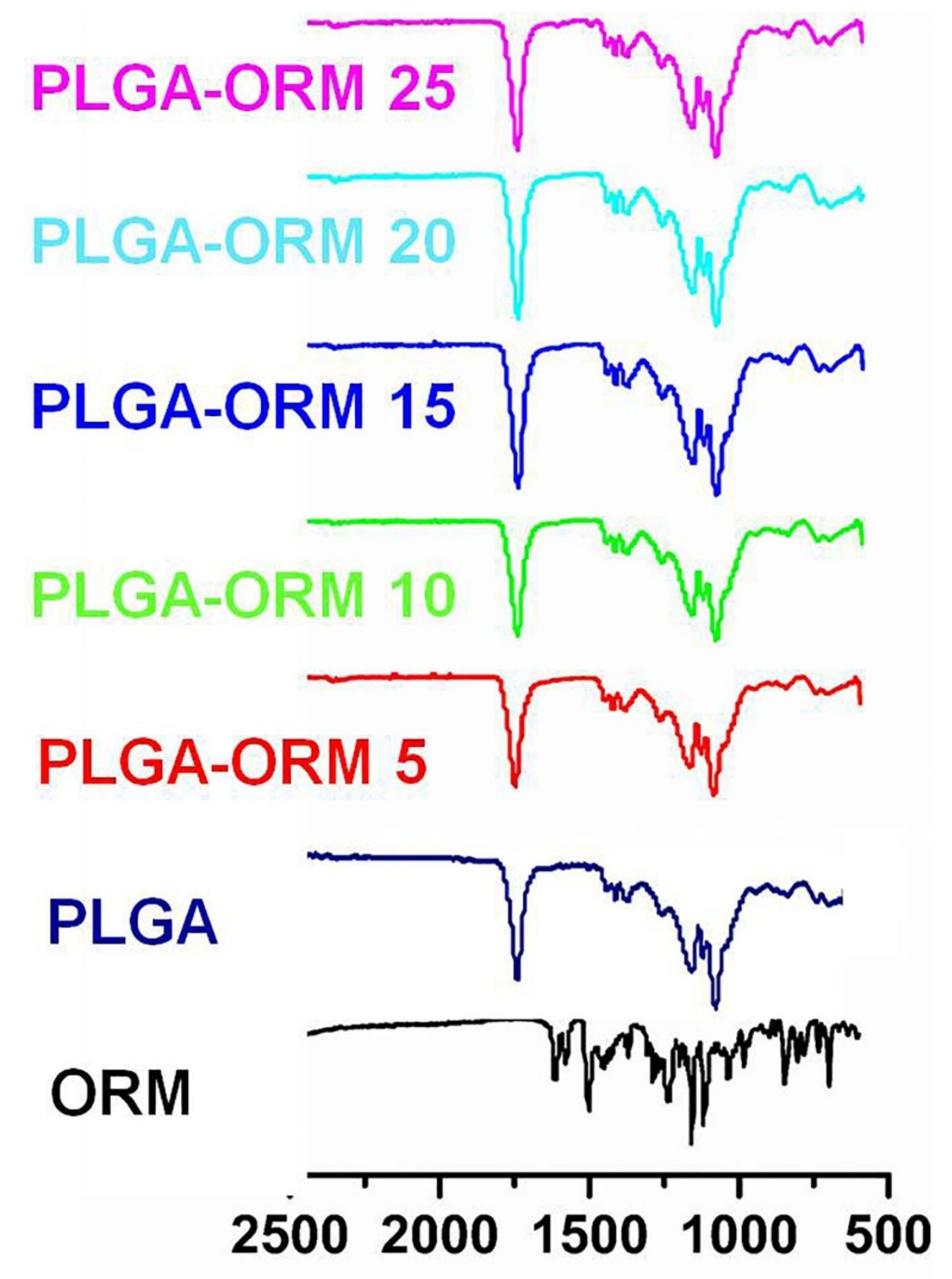

Figure 7-12. FT-IR spectra of ORM, PLGA NPs and PLGA-ORM NP formulations confirmed that ormeloxifene is successfully encapsulated in PLGA core.

Reprinted with permission. Khan, S., et al., Nanoparticle formulation of ormeloxifene for pancreatic cancer. Biomaterials, 2015. 53: p. 731-743. 


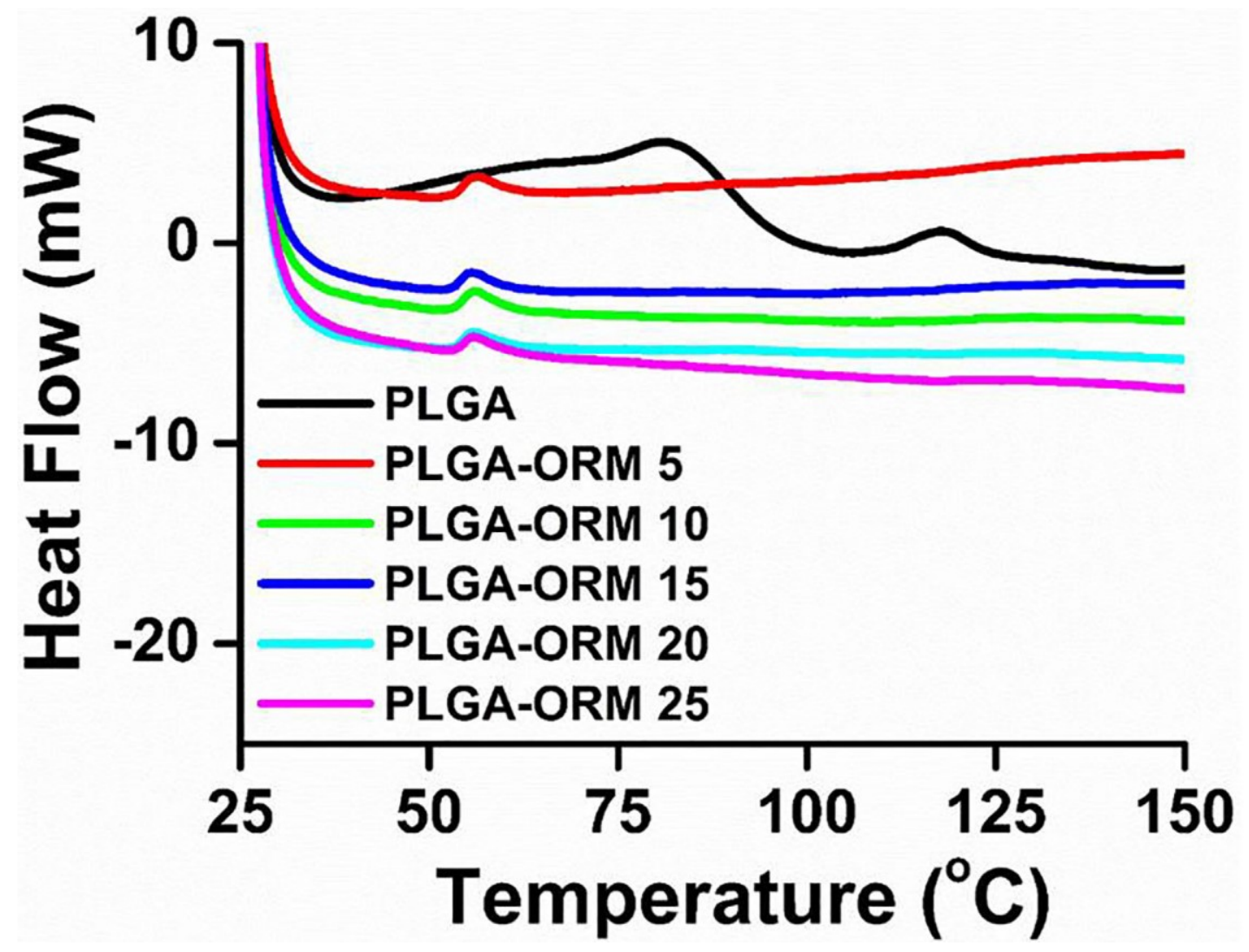

Figure 7-13. DSC endothermic curves of PLGA and PLGA-ORM NP nanoformulations confirmed that ormeloxifene is successfully encapsulated in PLGA core.

Reprinted with permission. Khan, S., et al., Nanoparticle formulation of ormeloxifene for pancreatic cancer. Biomaterials, 2015. 53: p. 731-743. 


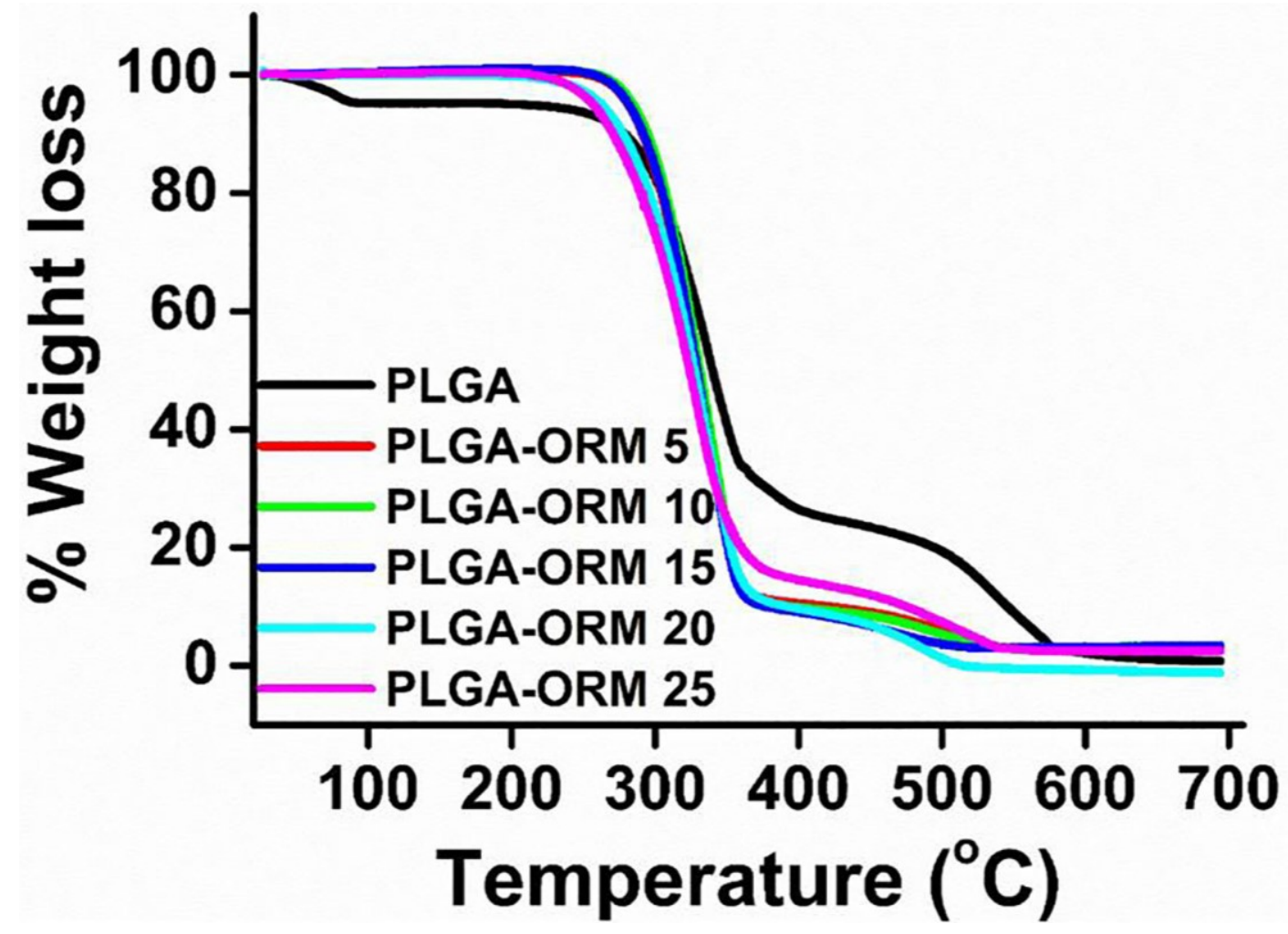

Figure 7-14. Thermogravimetric weight loss curves of PLGA and PLGA-ORM NP nanoformulations suggested ORM's successful incorporation in the PLGA-ORM NP formulation.

Reprinted with permission. Khan, S., et al., Nanoparticle formulation of ormeloxifene for pancreatic cancer. Biomaterials, 2015. 53: p. 731-743. 
encapsulation no additional peaks appeared in FT-IR spectra of PLGA-ORM NPs

(Figure 7-12), red to magenta lines, upwards). On the other hand, additional peaks were not attained in FT-IR after ORM encapsulation due to a higher degree of miscibility of ORM in the PLGA polymer matrix [196]. On the other hand, ORM may have been masked by the bands produced by the PLGA polymer matrix. This behavior was further confirmed with DSC analysis (Figure 7-13). DSC curves of pure PLGA NP formulation exhibit an endothermic peak at $\sim 79^{\circ} \mathrm{C}$ (Figure 7-13, black line), indicative of the glass transition temperature of the formulation. Due to incorporation of ORM in the PLGAORM formulations, an exothermic peak appeared at $\sim 58^{\circ} \mathrm{C}$ (Figure 7-13, red to magenta lines, downwards). Because of its superior blending of PLGA NPs and ORM in the PLGA-ORM NP formulations, PLGA glass transition peak disappeared or lowered the PLGA glass transition temperature. This indicates that ORM in nanoformulations is highly miscible. On the other hand, it appears that there is a significant reduction of crystallinity of the formulation. The presence of ORM in nanoformulations was further confirmed by TGA (Figure 7-14). The significant weight loss of PLGA NPs begins at $250^{\circ} \mathrm{C}$ to $580^{\circ} \mathrm{C}$ (Figure 7-14, black line). This behavior is further accelerated due to the presence of ORM in PLGA-ORM nanoformulations (Figure 7-14, red to magenta lines). Approximately, 55\% and $80 \%$ weight loss were observed at $350^{\circ} \mathrm{C}$ and $550^{\circ} \mathrm{C}$ for PLGA NP formulations while PLGA-ORM NP formulations show $74 \%$ and $95 \%$, respectively. Such greater weight loss is attributed to the presence of ORM in the nanoformulations.

\section{In vitro Release Profile}

In vitro drug release profile is an important experiment for developing a successful nanoformulation that qualifies for its use in vivo. Free drugs are readily available for the system so they can have a quick effect but soon they get cleared from the system. On the other hand nanoformulations release at the sustained rate, thus, carry better therapeutic efficacy over free drugs. The release profile of ORM from PLGAORM 20 is presented in (Figure 7-15) [192]. The release of ORM is relatively rapid at 1$3 \mathrm{hrs}$ and thereafter the release pattern is gradual and sustained.

\section{Serum Stability of PLGA-ORM}

Nanoparticles can easily aggregate or disintegrate or leak drug upon their administration to in vivo system where particles come in contact with systemic blood/serum. Therefore, it becomes necessary to evaluate stability of nanoparticles with serum. We utilized whole human serum to assess the stability of our PLGA-ORM nanoformulation. Results from absorption method indicated that this formulation is highly stable with human serum as confirmed by no or negligible change absorbance (Figure 7-16). Higher absorbance value is an indicative of higher degree of aggregation. 


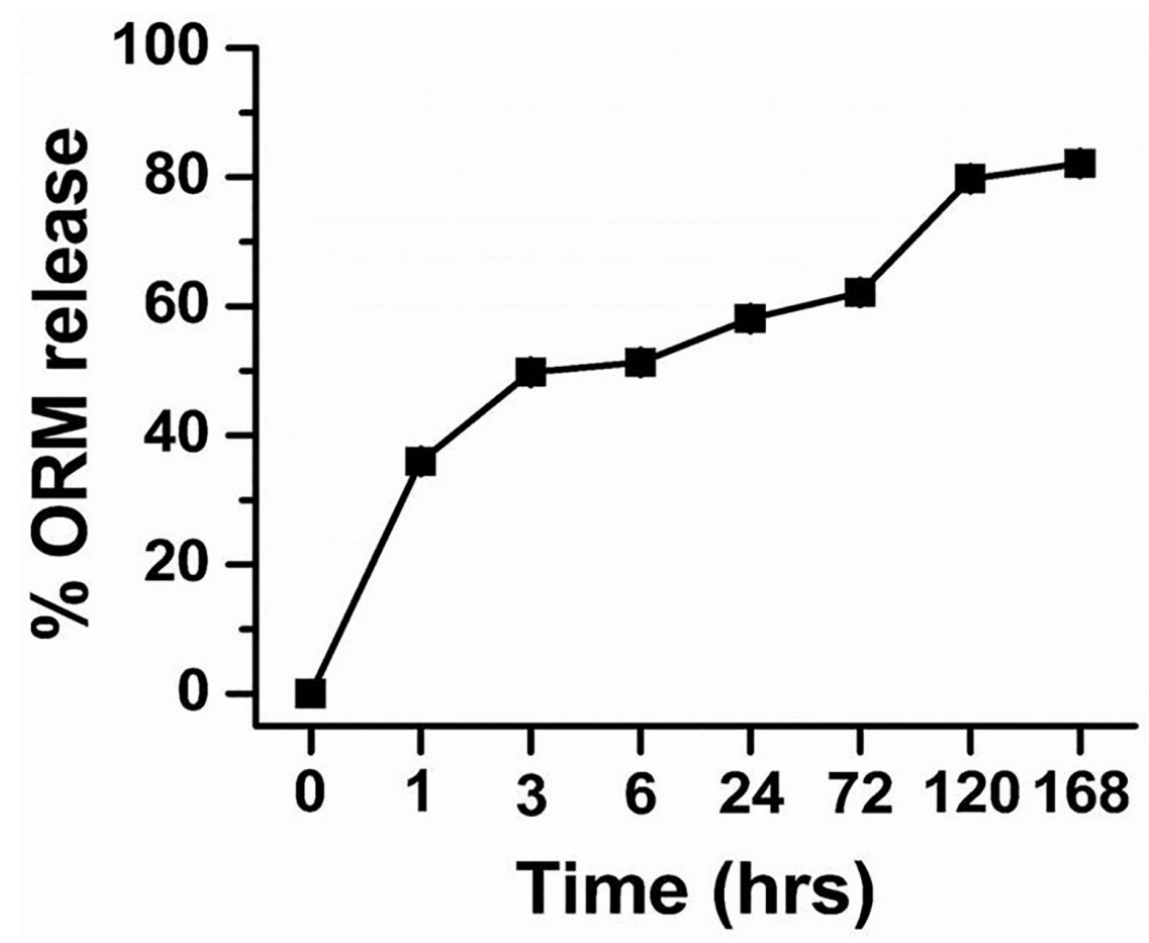

Figure 7-15. Sustained in vitro release profile of PLGA-ORM.

Reprinted with permission. Khan, S., et al., Nanoparticle formulation of ormeloxifene for pancreatic cancer. Biomaterials, 2015. 53: p. 731-743.

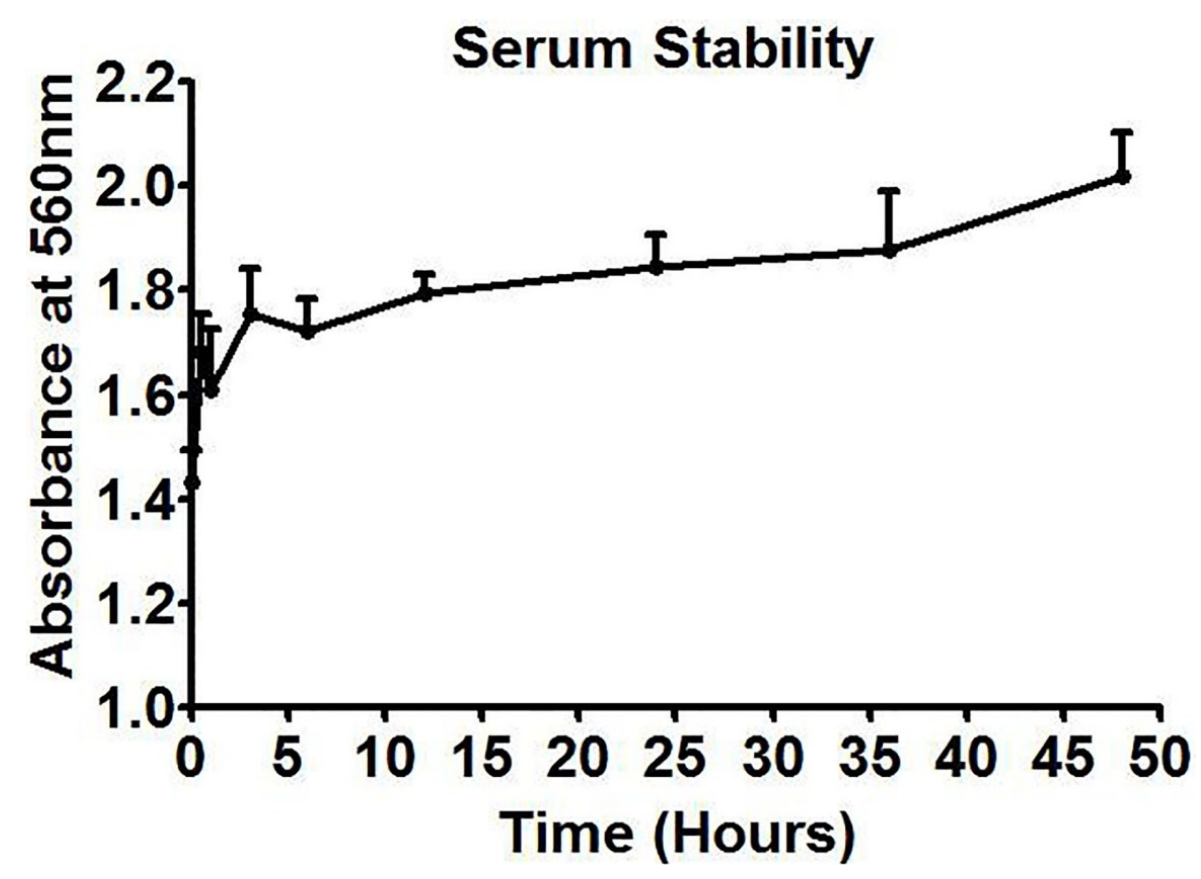

Figure 7-16. Whole human serum stability profile of PLGA-ORM. 


\title{
CHAPTER 8. EVALUATION OF IN VITRO UPTAKE AND ANTI- PROLIFERATIVE ACTIVITY OF PLGA-ORM
}

\author{
Materials and Methods
}

\section{Cellular Internalization of Nano-ORM in Caski and SiHa Cervical Cancer Cells}

To determine the cellular uptake of nanoparticles in cervical cancer cells, we incorporated $5 \mathrm{mg}$ coumarin- 6 green fluorescent dye with our PLGA-ORM formulation. 200,000 cells were seeded in 6-well plate and allowed to attach overnight. Next morning, cells were treated with coumarin-6 labeled PLGA-ORM and its vehicle control PLGA NPs respectively for 1 and 3 hours, washed twice with PBS and plates were imaged with a fluorescence microscope (Nikon Eclipse, Melville, NY). After imaging cells were trypsinized, washed with PBS and collected for uptake measurement by flow cytometer. Fluorescence levels from cells were measured with FL1 channel in Accuri C6 flow cytometer (BD Biosciences, CA)

\section{Transmission Electron Microscopy (TEM)}

For the uptake analysis by TEM, we plated Caski and SiHa cells at 200,000/well in 6 well plates and allowed to adhere overnight. Next morning, cells were treated with free ORM, PLGA-ORM and their vehicle controls ETOH and PLGA NPs respectively for 3 hours. After 3 hours, cells were trypsinized, washed with PBS, centrifuged and the pellet was collected. After the final pellet collection, it was fixed with $2 \%$ glutaraldehyde buffer, rinsed with $100 \mathrm{mM} \mathrm{Na}$-cacodylate and further processed for TEM analysis.

\section{Cell Association Study}

Both cells were plated in $60 \mathrm{~mm}$ dish for the overnight attachment. Next day, cells were pre-incubated either at physiological temperature $37^{\circ} \mathrm{C}$ or at cold temperature $4^{\circ} \mathrm{C}$ for an hour before the drug treatment. After an hour, cells were exposed to coumarin- 6 (green fluorescent dye) labeled PLGA-ORM nanoparticles at 10, 20 and $25 \mu \mathrm{M}$ concentrations for an additional hour. Next, cells were washed twice with PBS, trypsized, centrifuged, collected in PBS and analyzed with Accuri BD C6 flow cytometer in FL1 channel.

\section{Cellular Uptake Mechanism}

For this analysis, both cell lines Caski and SiHa were seeded at $2 \times 10^{5} /$ well in a 6well format plate and allowed to attach overnight. Next morning, cells were pretreated with different endocytosis pathway inhibitors such as Genistein (caveola mediated 
endocytosis at $200 \mu \mathrm{M}$ ), Amiloride (micropinocytosis endocytosis at $10 \mathrm{mM}$ ), Nocodazol (microtubule mediated endocytosis at $20 \mu \mathrm{M}$ ), Chloropromazen (clathrin mediated endocytosis at $10 \mu \mathrm{g} / \mathrm{mL}$ ) and Methyle- $\beta$-cyclodextrin (lipid rafts mediated endocytosis at $10 \mathrm{mM}$ ) for 1 hour. Thereafter, cells were exposed to coumarin-6 (green fluorescent dye) labeled PLGA-ORM nanoparticles for the next hour at $37^{\circ} \mathrm{C}$. After an hour, cells were washed twice with PBS, trypsinized, centrifuged, collected in PBS and analyzed with Accuri BC C6 flow cytometer in FL1 channel.

\section{Cell Proliferation}

Both Caski and SiHa (5000 cells/well) cell lines were seeded in 96 well plates and allowed to attach overnight. Following day, cells were treated with different micromolar concentrations (ranging from 10, 20 and $30 \mu \mathrm{M}$ of free ORM and PLGA-ORM and were incubated for 48 hour time course. Assay was performed by utilizing an MTS CellTiter96 Aqueous One Solution. At the end of the indicated time point, $20 \mu \mathrm{L}$ MTS reagent was added to each well and incubated at $37^{\circ} \mathrm{C}$ for next 2-4 hours. The absorbency was measured at $490 \mathrm{~nm}$ by using microplate spectra photometer. Experiment was done in duplicates and repeated three individual times. Data was compared to vehicle controls.

\section{Colony Formation Assay}

Caski and SiHa cells were seeded at 500/well in 6 well plates and allowed to adhere overnight. Following day, cells were treated with $2.5,5,10 \mu \mathrm{M}$ of free ORM and PLGA-ORM and their respective vehicle controls and maintained for another 12-14 days. On the $14^{\text {th }}$ day cells were washed with PBS, fixed with ice cold methanol, stained with hematoxylin (Thermo Fisher), and washed with water. Colonies that were visible ( $\sim 50$ cells) were counted manually and compared to the vehicle control ETOH and PLGA control to obtain the final result. Experiment was done in duplicate and repeated three individual times.

\section{Real Time Cell Proliferation Kinetic Assay Using xCELLigence System}

The xCELLigence system was used in order to evaluate the effects of PLGAORM on real time cellular proliferation/growth kinetics. xCELLigence system is an electrical impedance-based method that provides the real time proliferation measurements. For this experiment we used E plate VIEW 16 (ACEA Biosciences) which were pre-incubated with $30 \mu \mathrm{L}$ media for $30 \mathrm{~min}$ at $37^{\circ} \mathrm{C}$ and for the background measurement. After $30 \mathrm{~min}$, Caski and SiHa cells were plated at $8 \times 10^{3} /$ chamber in 100 $\mu \mathrm{L}$ media with drug treatments $(20 \mu \mathrm{M}$ ormeloxifene and PLGA-ORM) in it. Plates were incubated in xCELLigence instrument chamber at $37^{\circ} \mathrm{C}$ with $5 \% \mathrm{CO}_{2}$ for real time cell proliferation analysis. Experiment was done twice. 


\section{Mitochondrial Membrane Potential by TMRE}

Both Caski and SiHa cells were plated at 200,000/well in 6 well plates and allowed to attach overnight. Next day cells were exposed to ORM and PLGA-ORM at 25 $\mu \mathrm{M}$ concentration along with their vehicle controls. At the indicated time point, cells were trypsinized, washed, centrifuged and the final pellet was resuspended in $1 \mathrm{~mL}$ PBS containing $50 \mathrm{nM}$ TMRE stain. Cells were incubated with TMRE for 30 minutes in the dark at room temperature. After the incubation is completed, cells were analyzed by BD Accuri C6 flow cytometer under FL2 channel. The experiment was performed three times.

\section{Statistical Analysis}

Statistical analysis was determined by using an unpaired, two tailed student's ttest. The results were considered significant if $P<0.05$. All graphs were generated using GraphPad Prism5 software.

\section{Results}

\section{PLGA-ORM Nanoparticles Internalize in Cervical Cancer Cells}

Measuring in vitro cellular internalization of nanoparticle is an essential experiment. We used fluorescent microscope and flow cytometer for measuring the cellular uptake of PLGA-ORM nanoparticles in cervical cancer calls. The microscopic images and flow cytometer data revealed that particles were being taken up by Caski (Figure 8-1 and Figure 8-2) and SiHa (Figure 8-3 and Figure 8-4) cell lines in time and dose dependent manners. These images suggested that PLGA-ORM was primarily located at the cytoplasm of these cells. TEM images data (Figure 8-5, Figure 8-6, Figure 8-7 and Figure 8-8) was also consistent with this finding. TEM images revealed that PLGA-ORM was internalized in cells just with 3 hours of treatment while no uptake was seen in free ORM treated samples. Temperature is an important factor that facilitates the uptake of particles. In some cases, particle uptake is energy/temperature dependent. Thus, we conducted a flow cytometry study with two different temperatures. The results from this experiment showed that at $4^{\circ} \mathrm{C}$ temperature particle uptake was blocked whereas at $37^{\circ} \mathrm{C}$, the physiological temperature, the uptake of particles was normal (Figure 8-9 and Figure 8-10).

\section{PLGA-ORM Nanoparticles Utilizes Endocytosis Pathway for Internalization in Cervical Cancer Cells}

Endocytosis is the main pathway that nanoparticles use for internalizing into the cells. But endocytosis has various different mechanisms/pathways for cellular uptake 

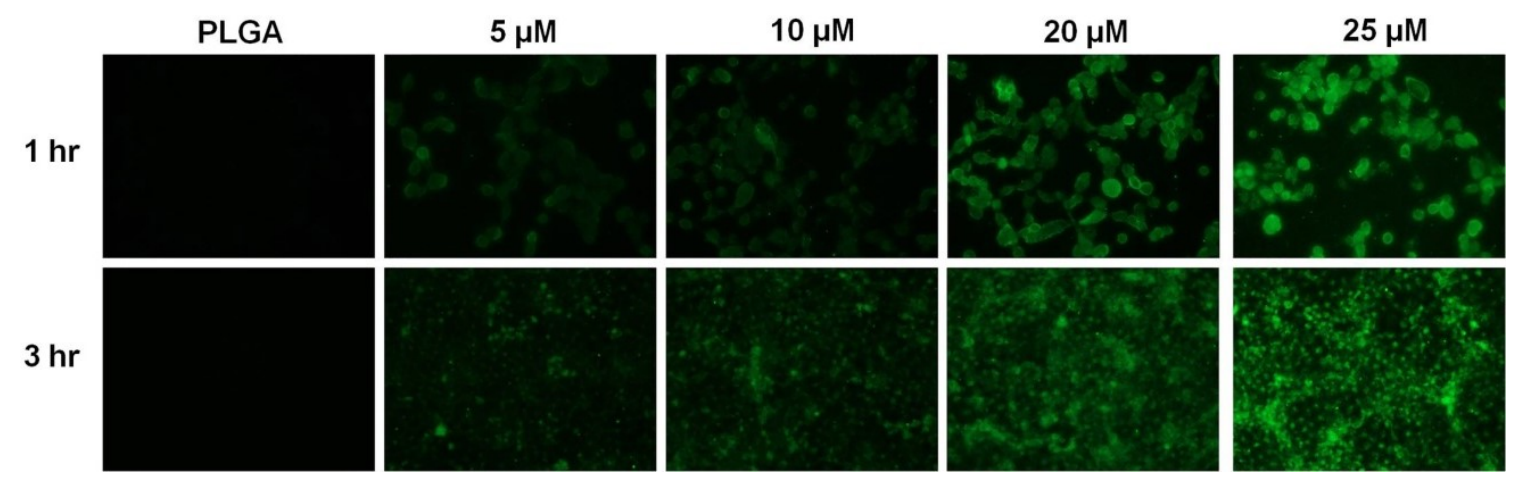

Figure 8-1. Qualitative representation of cellular uptake of coumarin-6 loaded PLGA-ORM nanoparticles in Caski cells.

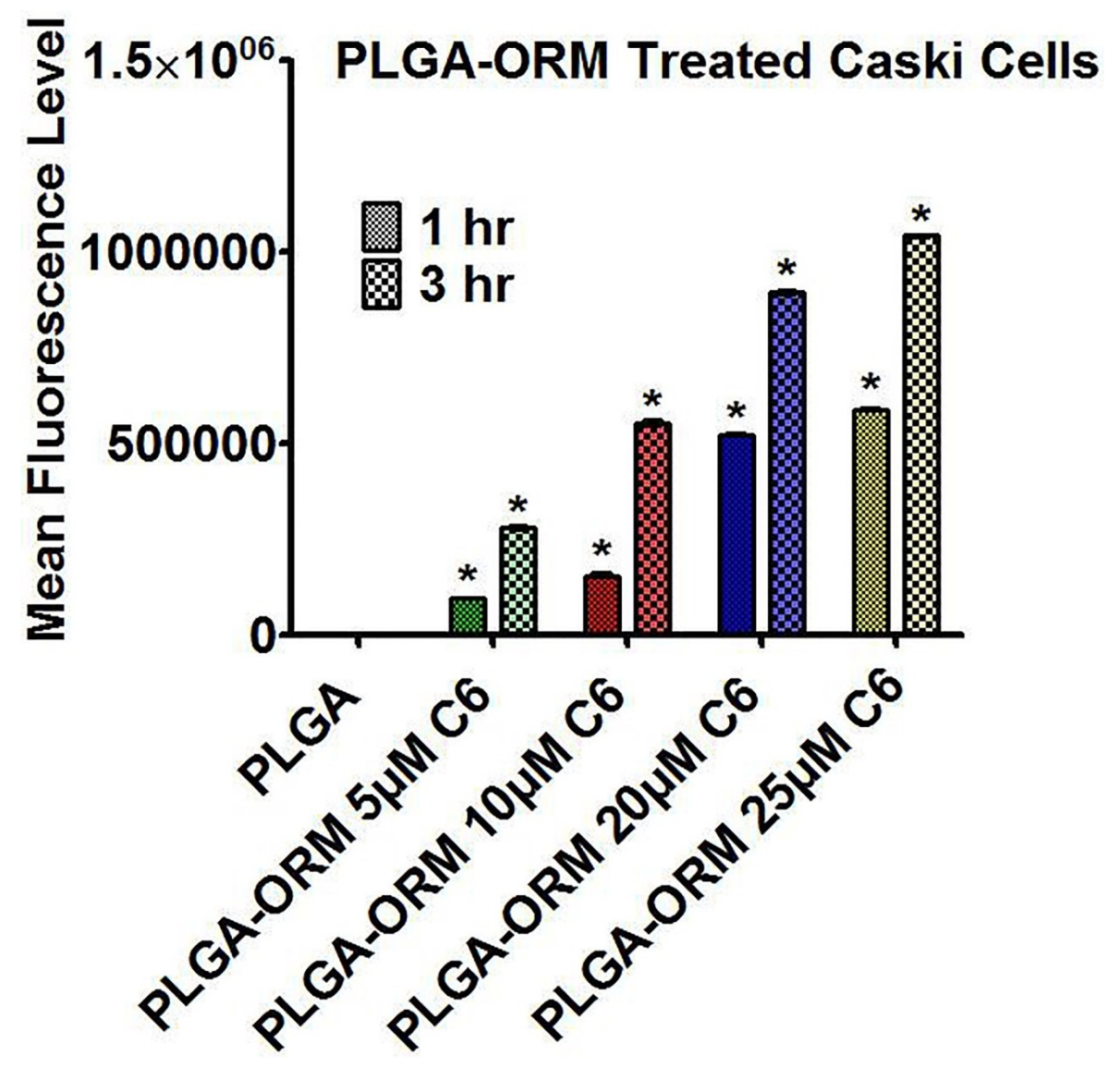

Figure 8-2. Coumarin-6 loaded PLGA-ORM internalization in Caski cells. Cells showed an increasing uptake pattern of particles in dose and time dependent manner. Results were normalized to the PLGA control particles. Error bars show SEM, $\mathrm{n}=3 .{ }^{*} \mathrm{p}<0.05$. 


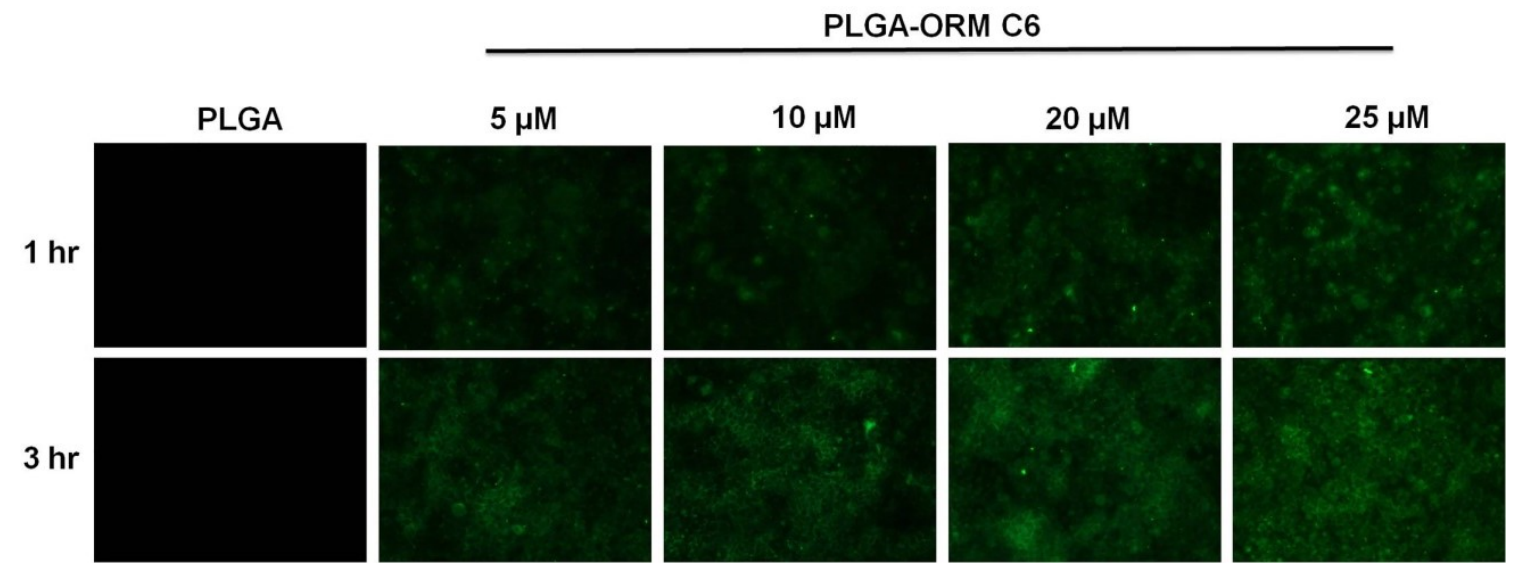

Figure 8-3. Qualitative representation of cellular uptake of coumarin-6 loaded PLGA-ORM nanoparticles in SiHa cells. 


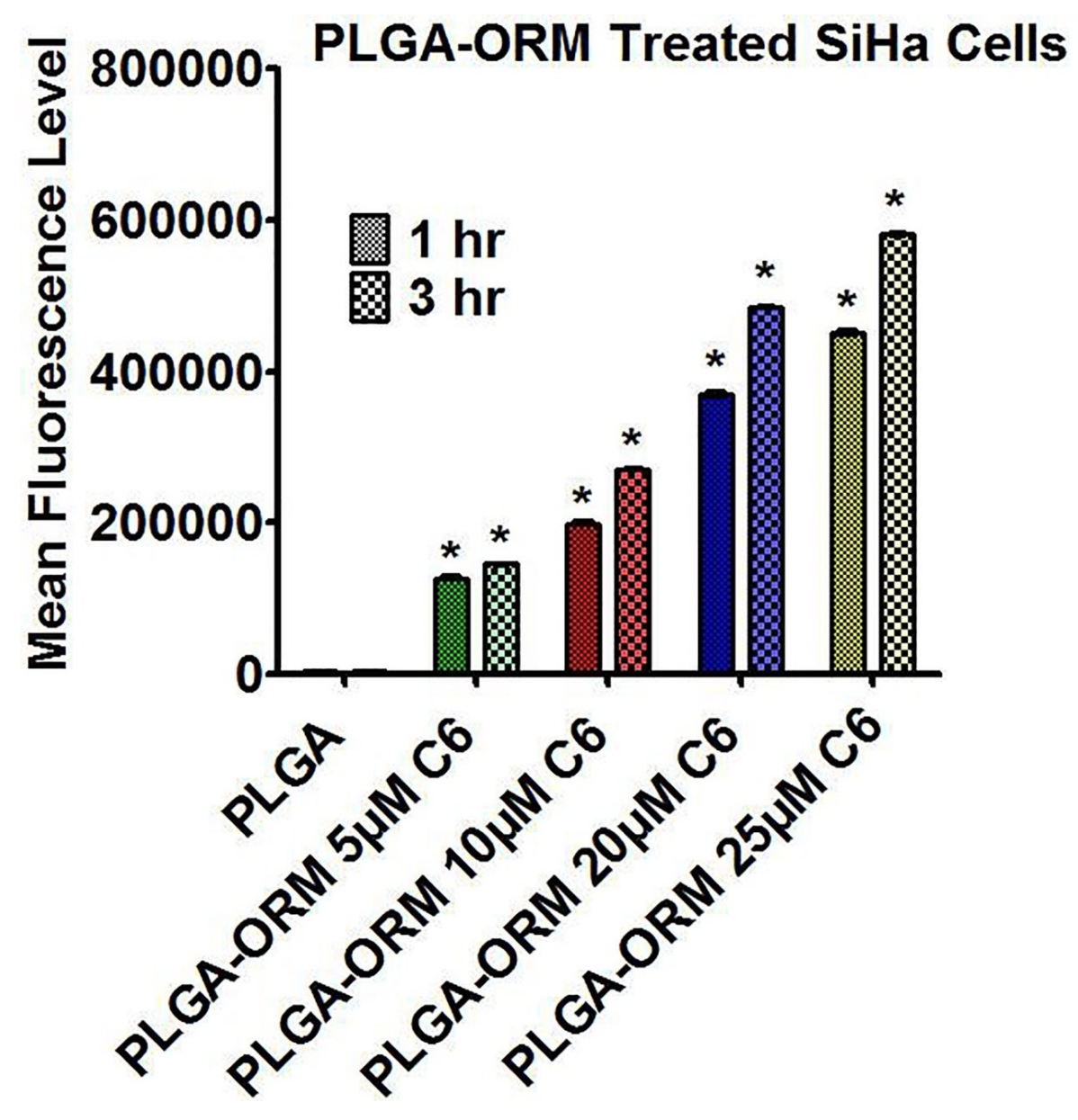

Figure 8-4. Coumarin-6 loaded PLGA-ORM internalization in SiHa cells. Cells showed an increasing uptake pattern of particles in dose and time dependent manner. Results were normalized to the PLGA control particles. Error bars show SEM, $\mathrm{n}=3 .{ }^{*} \mathrm{p}<0.05$. 


\section{Caski $25 \mu \mathrm{M}$ ORM}

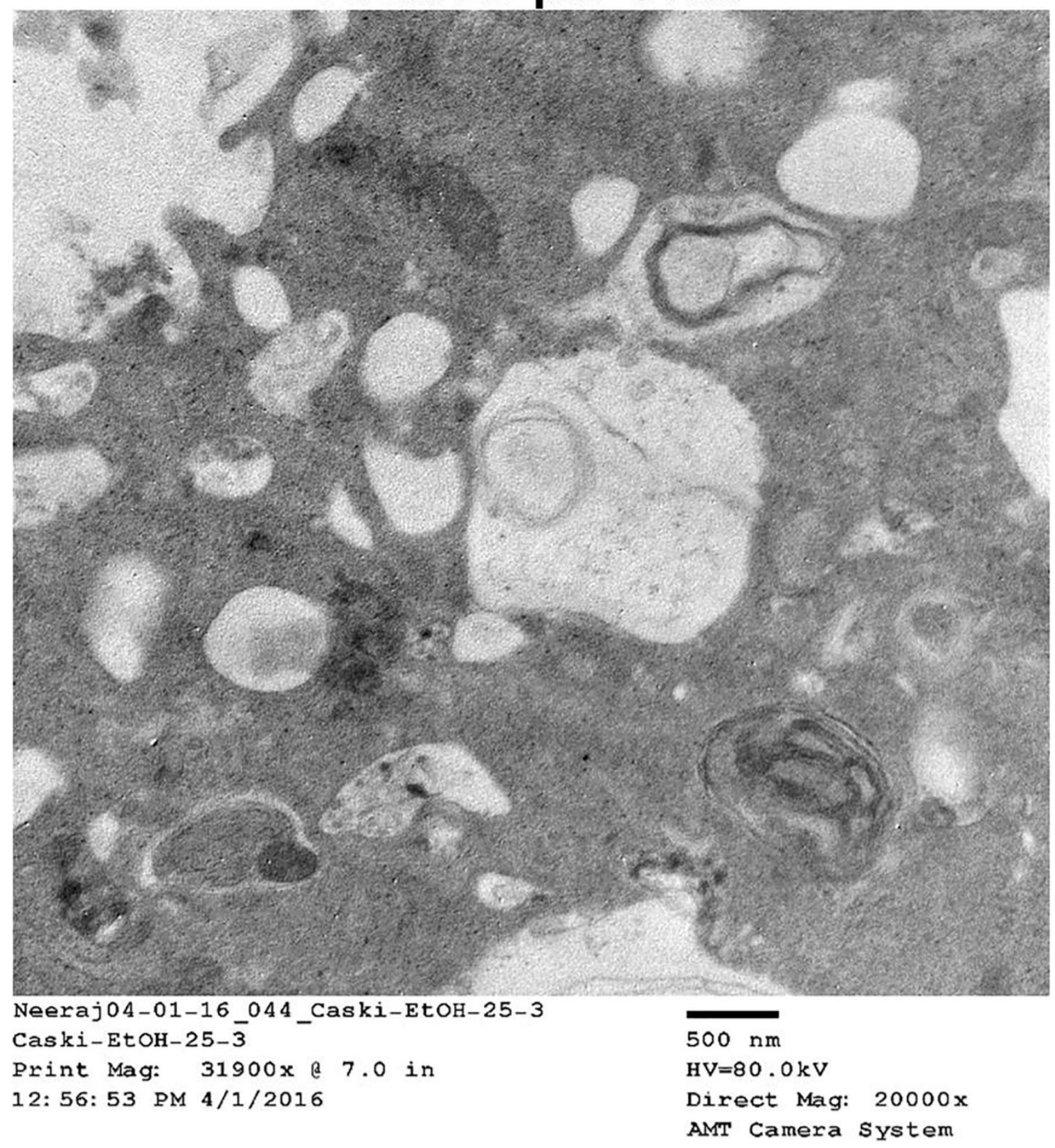

Figure 8-5. Cellular internalization of free ORM in Caski cells showed by TEM. 


\section{Caski $25 \mu M$ PLGA-ORM}

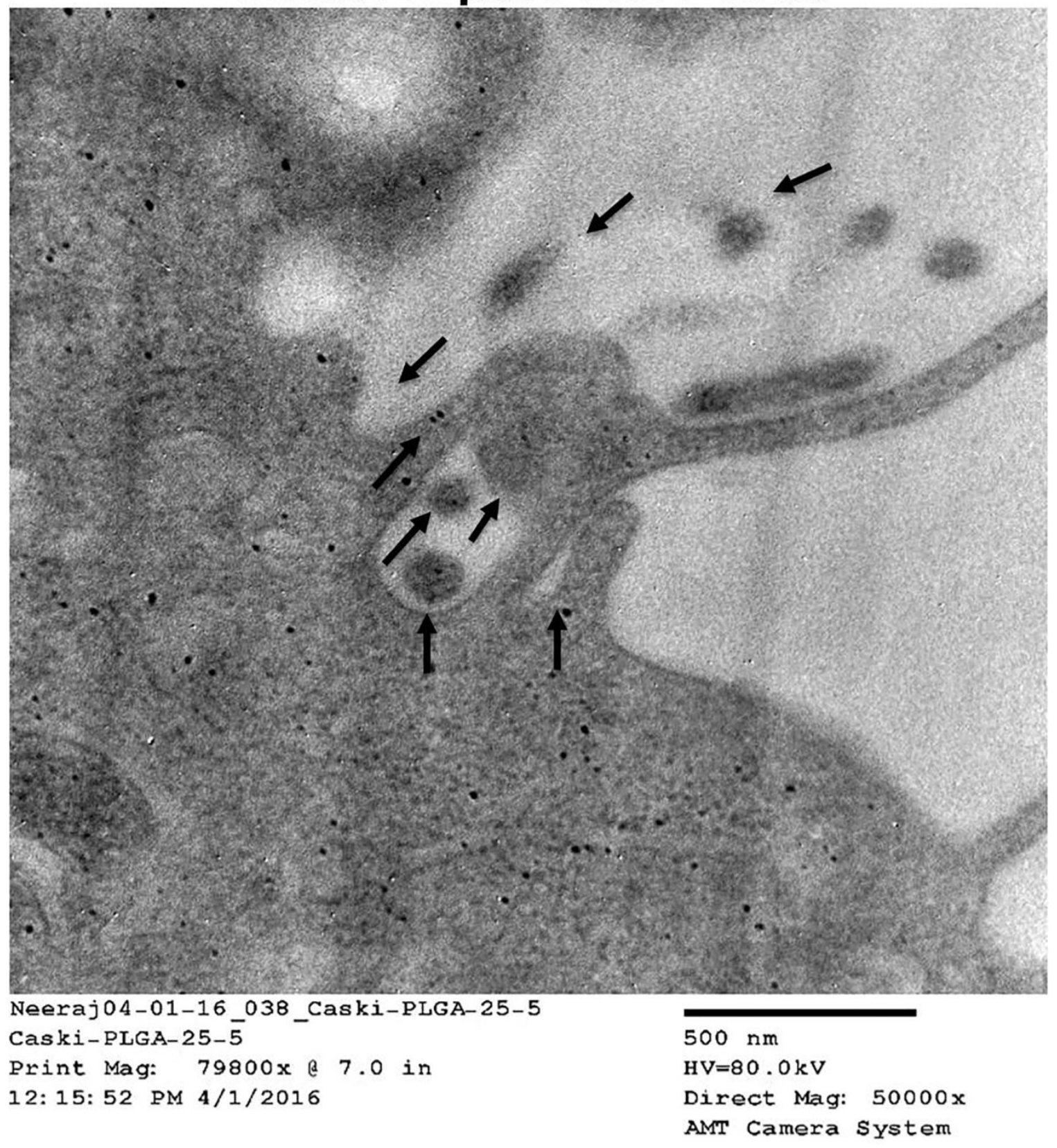

Figure 8-6. Cellular internalization of PLGA-ORM in Caski cells showed by TEM. 


\section{SiHa $25 \mu M$ ORM}

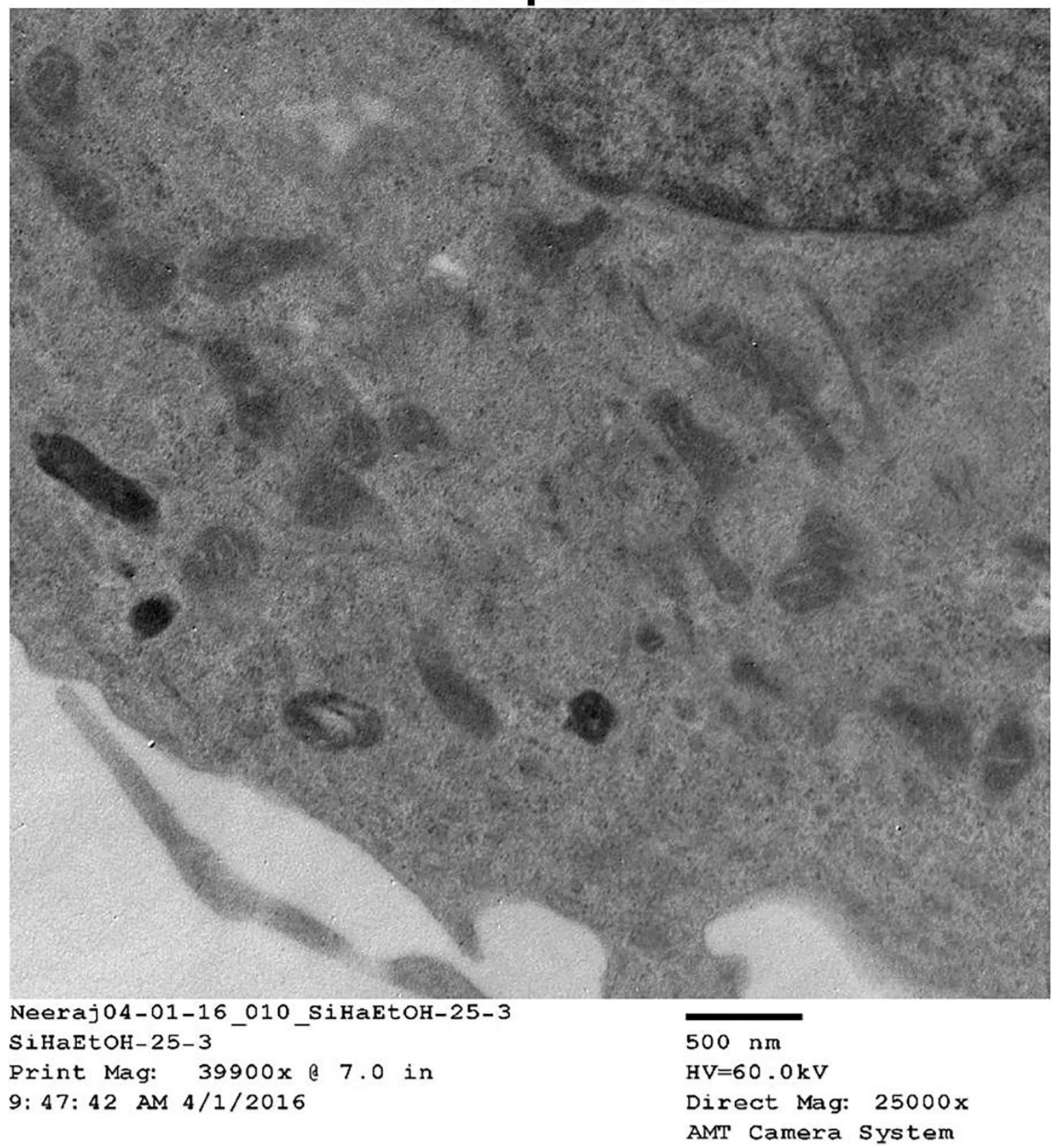

Figure 8-7. Cellular internalization of free ORM in SiHa cells showed by TEM. 


\section{SiHa $25 \mu M$ PLGA-ORM}

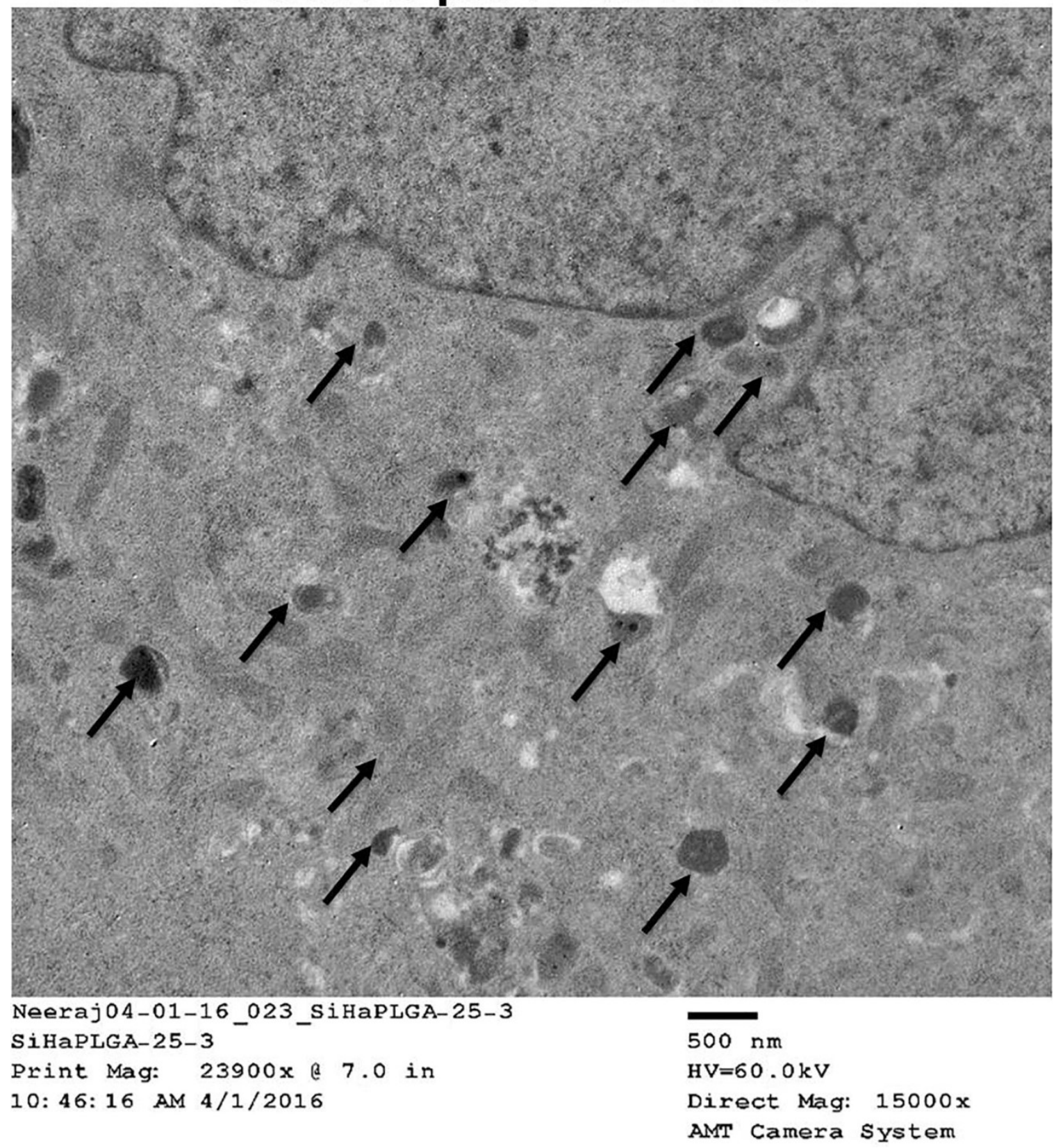

Figure 8-8. Cellular internalization of PLGA-ORM in SiHa cells showed by TEM. 


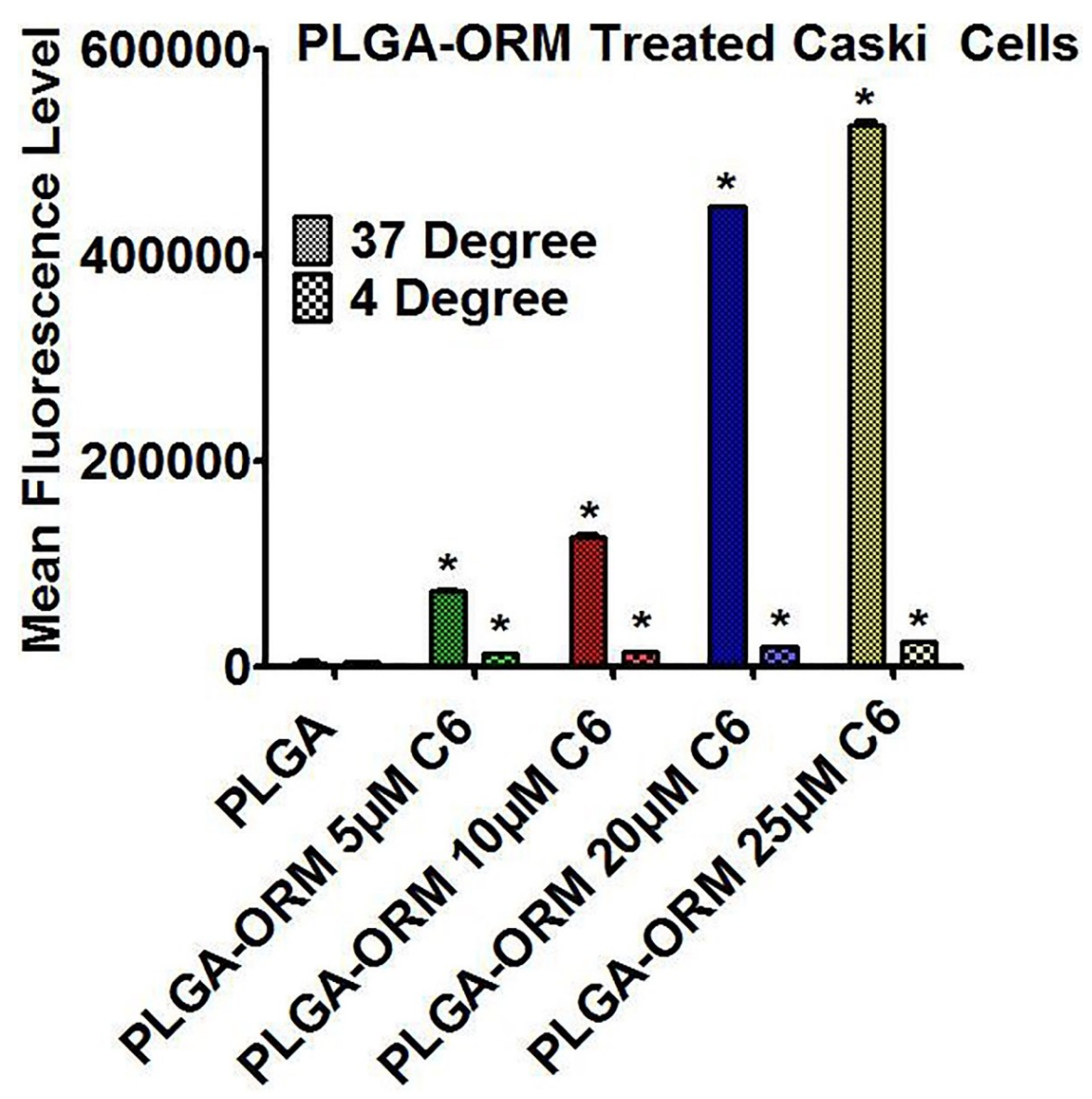

Figure 8-9. Internalization of Coumarin-6 loaded PLGA-ORM is energy dependent in Caski cells.

Cells showed blocked or inhibited uptake of particles when incubated at $4^{\circ} \mathrm{C}$ temperature. Results were normalized to the PLGA control particles. Error bars show SEM, $\mathrm{n}=3 .{ }^{*} \mathrm{p}<0.05$. 


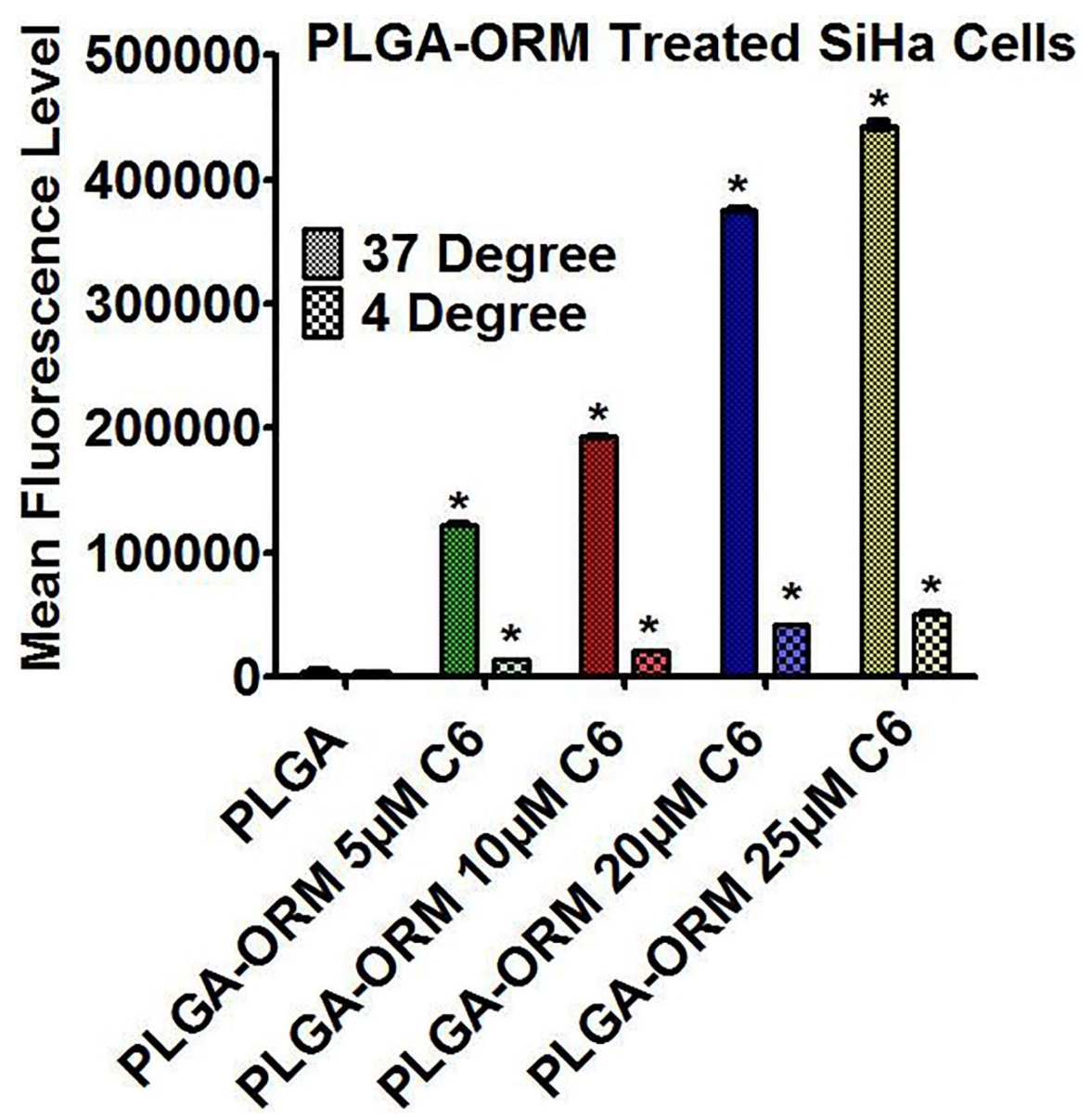

Figure 8-10. Internalization of Coumarin-6 loaded PLGA-ORM is energy dependent in SiHa cells.

Cells showed blocked or inhibited uptake of particles when incubated at $4^{\circ} \mathrm{C}$ temperature. Results were normalized to the PLGA control particles. Error bars show SEM, $\mathrm{n}=3 .{ }^{*} \mathrm{p}<0.05$. 
(Figure 8-11) [197]. Therefore to determine the uptake mechanism of PLGA-ORM nanoparticles, we treated Caski and SiHa cells with different endocytosis pathway inhibitors and performed flow cytometery. Data from this experiment suggested that particles mainly utilized the lipid raft, caveolae and micropinocytosis pathways to get into the Caski cells (Figure 8-12). While in SiHa cells particles preferred lipid raft, clatherin, caveolae and micropinocytosis pathways for their internalization (Figure 8-13).

\section{PLGA-ORM Decreases Cellular Viability, Clonogenic Potential and Mitochondrial Membrane Potential of Cervical Cancer Cells}

In order to elaborate anti-cancerous properties of PLGA-ORM, we assessed an MTS assay for 48 hours. The results showed a marked decrease in cellular viability of both cell lines (Figure 8-14 and Figure 8-15) when compared to free ORM. When we performed the colony formation assay for the long term treatment capability of PLGAORM, the results were even better. PLGA-ORM had an inhibitory effect on clonogenic potential of both Caski and $\mathrm{SiHa}$ cells in comparison to free ORM (Figure 8-16, Figure 8-17, Figure 8-18 and Figure 8-19). Interestingly, PLGA-ORM had lower number of colonies than free ORM even at the lowest concentration of $2.5 \mu \mathrm{M}$. Real time growth kinetics by the xCELLigence system also supported these findings (Figure 8-20 and Figure 8-21). We also performed a Flow cytometry experiment to analyze the ability of PLGA-ORM to induce apoptosis. We used TMRE stain to detect the depolarized mitochondria which is an indication of apoptosis induction. Our flow cytometer data revealed that PLGA-ORM significantly reduced the mitochondrial membrane potential of both Caski and SiHa cells when compared to free ORM (Figure 8-22 and Figure 8-23). 


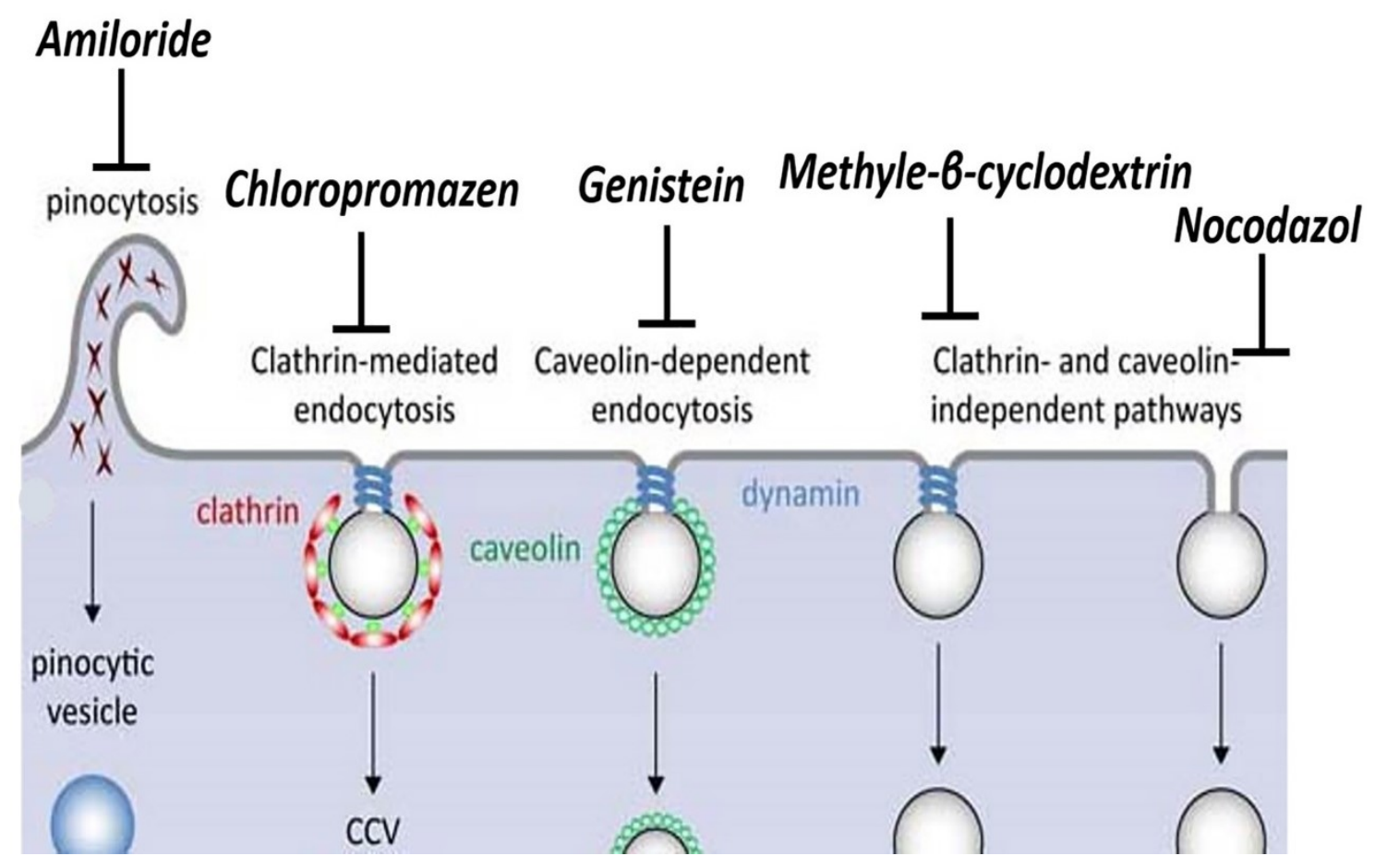

Figure 8-11. Representation of different endocytosis pathway and their inhibitors. Modified with permission. Mayor, S. and R.E. Pagano, Pathways of clathrin-independent endocytosis. Nature reviews Molecular cell biology, 2007. 8(8): p. 603-612. 


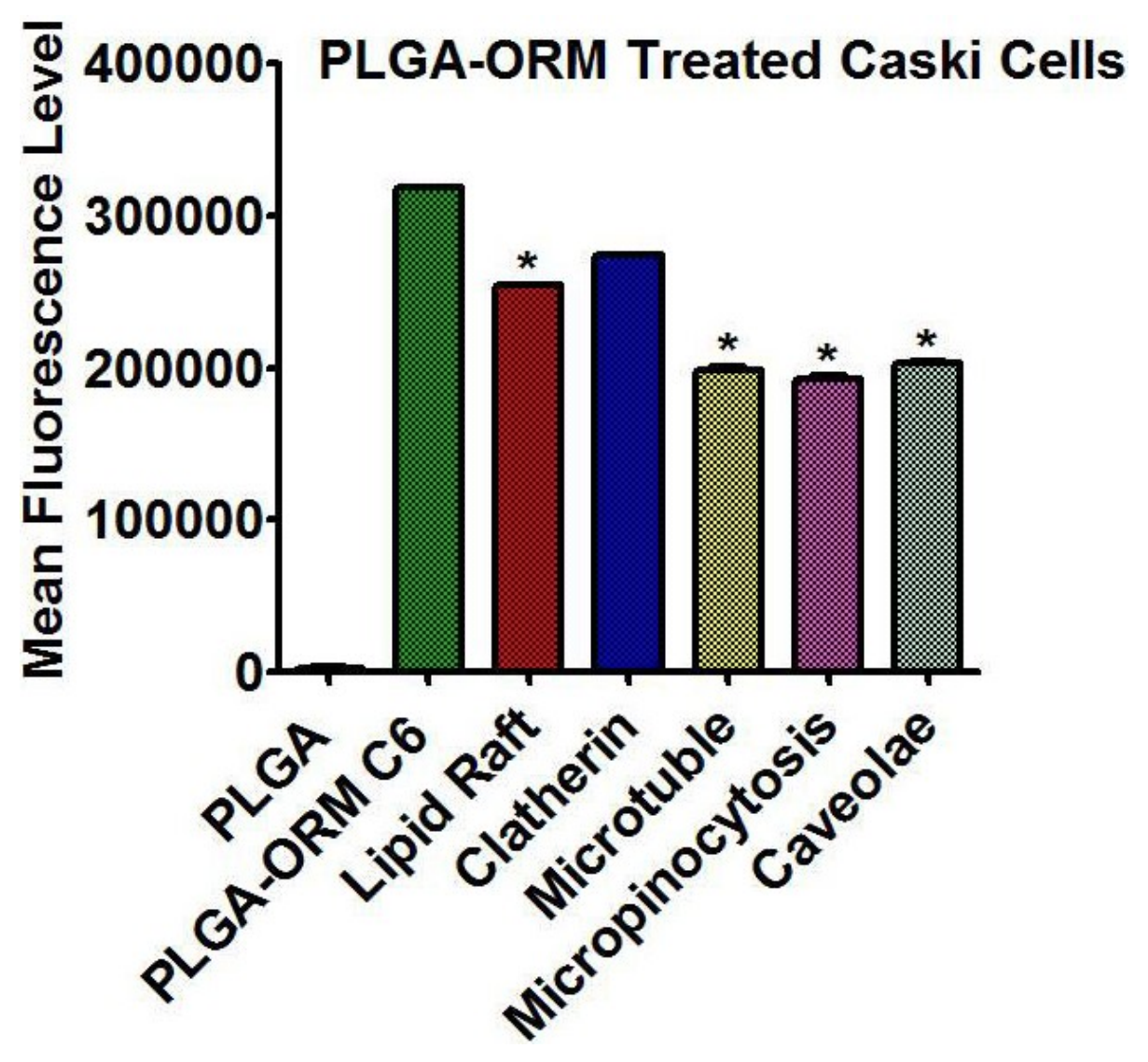

Figure 8-12. PLGA-ORM nanoparticles entered Caski cells using endocytosis pathway.

Cellular uptake of formulation after using different endocytosis pathway inhibitors.

Results were normalized to the PLGA-ORM C6 particles. Error bars show SEM, n=3. $* \mathrm{p}<0.05$. 


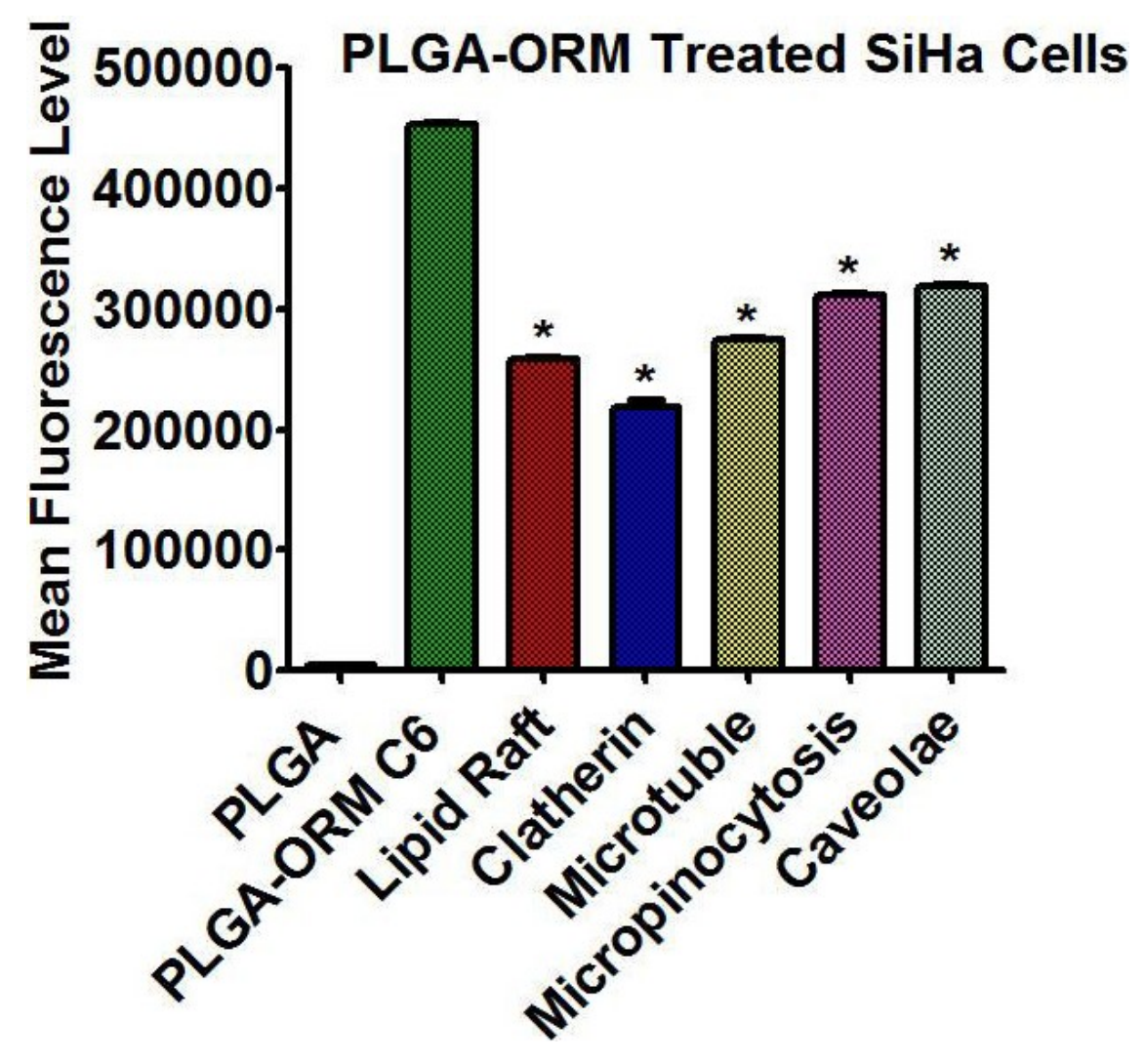

Figure 8-13. PLGA-ORM nanoparticles entered SiHa cells using endocytosis pathway.

Cellular uptake of formulation after using different endocytosis pathway inhibitors.

Results were normalized to the PLGA-ORM C6 particles. Error bars show SEM, n=3. $* \mathrm{p}<0.05$. 


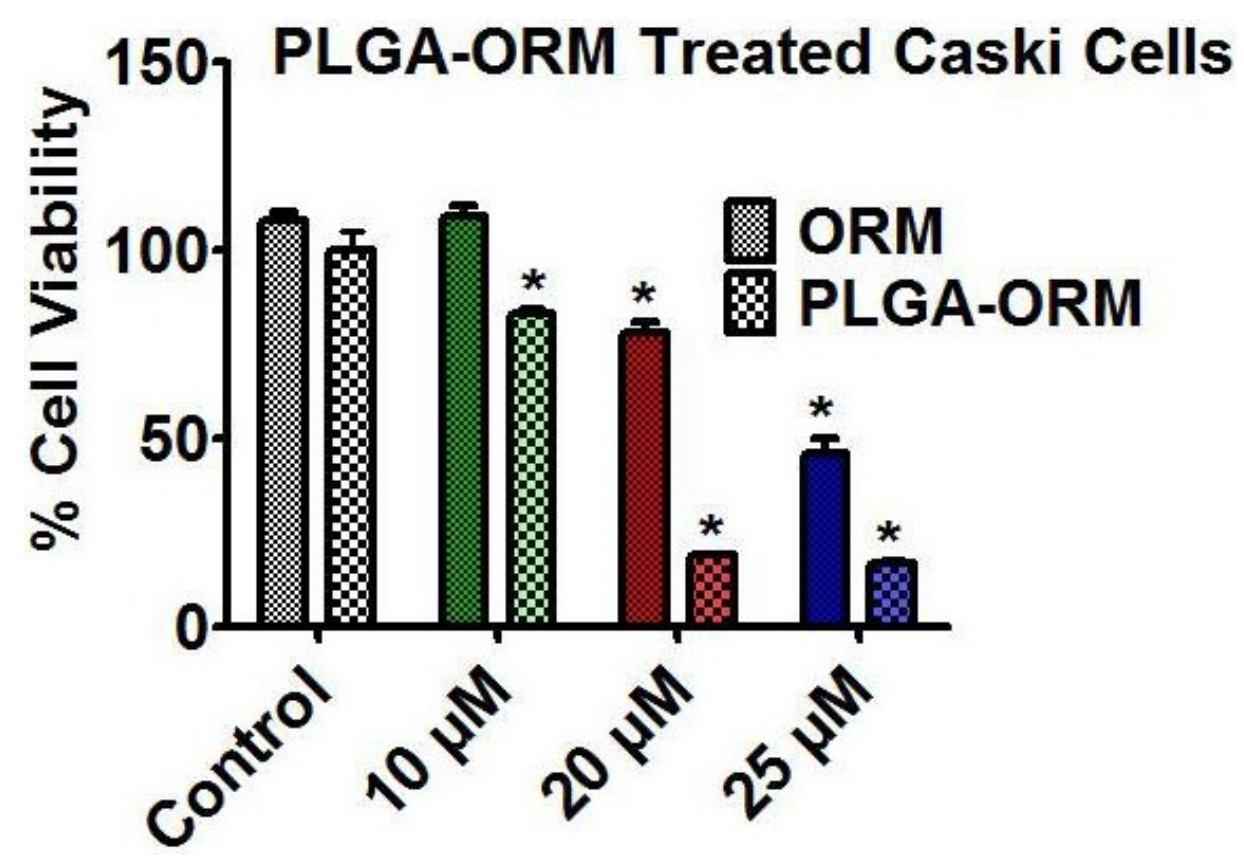

Figure 8-14. PLGA-ORM decreased cellular proliferation of Caski cells.

Cells were treated with ormeloxifene and PLGA-ORM (10, 20 and $30 \mu \mathrm{M})$ for $48 \mathrm{hrs,}$ MTS method was used to determine proliferation, and absorbance was measured at 490 $\mathrm{nm}$. Results were normalized to the vehicle controls (ETOH and PLGA) and free ormeloxifene. Error bars show SEM, $\mathrm{n}=3 .{ }^{*} \mathrm{p}<0.05$. 


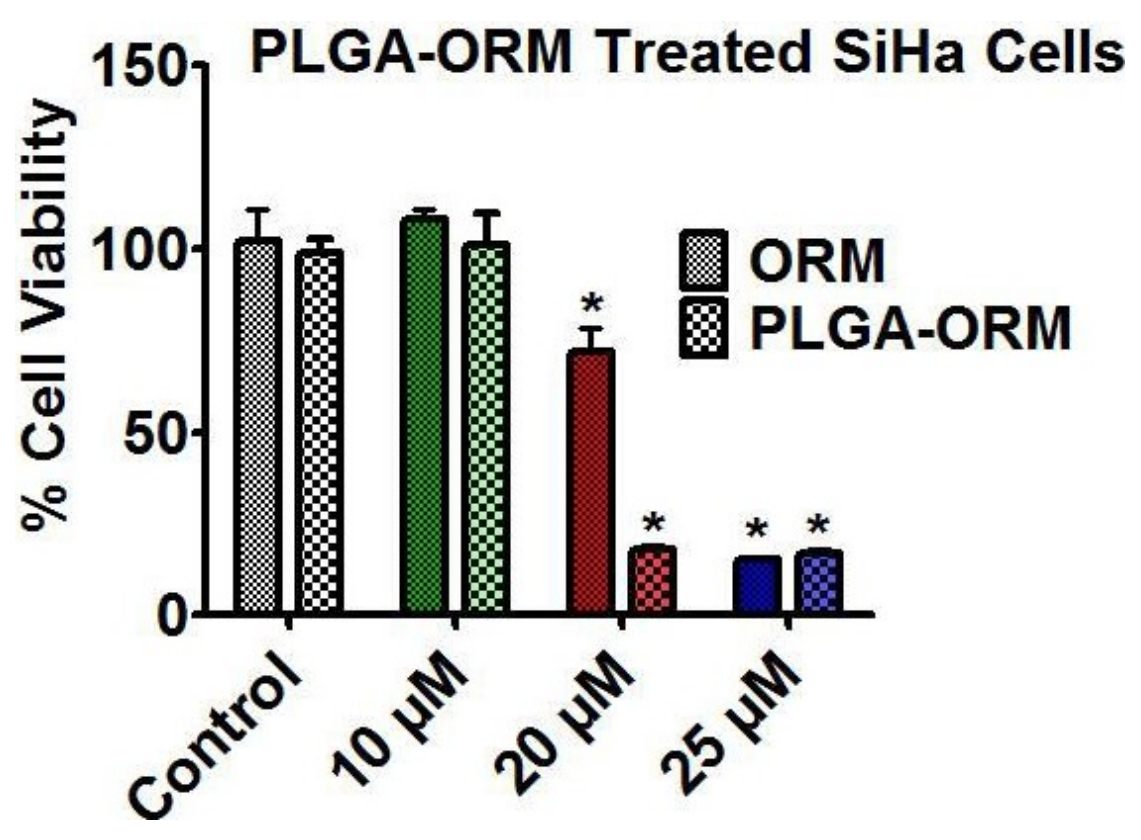

Figure 8-15. PLGA-ORM decreased cellular proliferation of SiHa cells.

Cells were treated with ormeloxifene and PLGA-ORM $(10,20$ and $30 \mu \mathrm{M})$ for $48 \mathrm{hrs,}$ MTS method was used to determine proliferation, and absorbance was measured at 490 $\mathrm{nm}$. Results were normalized to the vehicle controls (ETOH and PLGA) and free ormeloxifene. Error bars show SEM, $n=3 .{ }^{*} \mathrm{p}<0.05$.

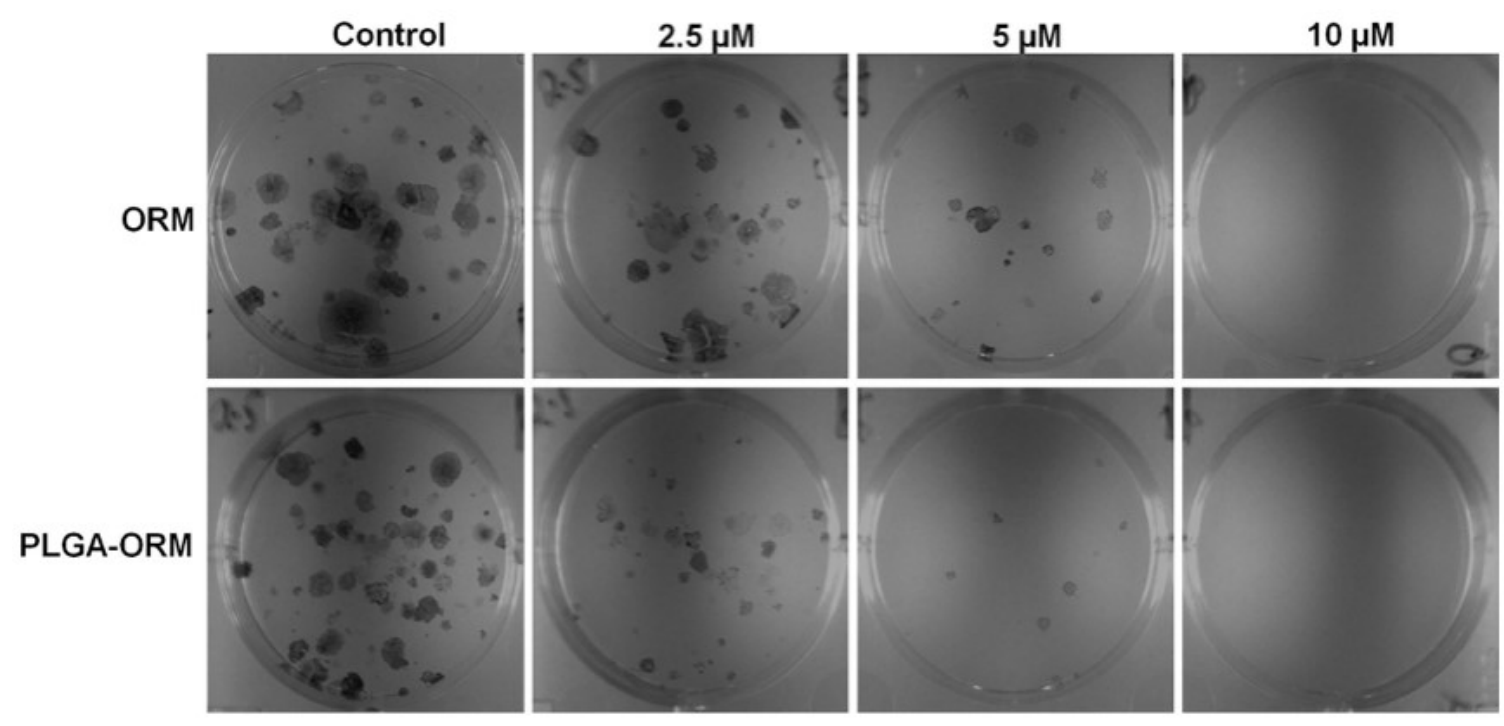

Figure 8-16. PLGA-ORM decreased colony forming ability of Caski cells. Cells were treated with ormeloxifene and PLGA-ORM $(2.5,5$ and $10 \mu \mathrm{M})$ for 14 days. Images were taken at $200 \mathrm{X}$ using a phase contrast microscope. 


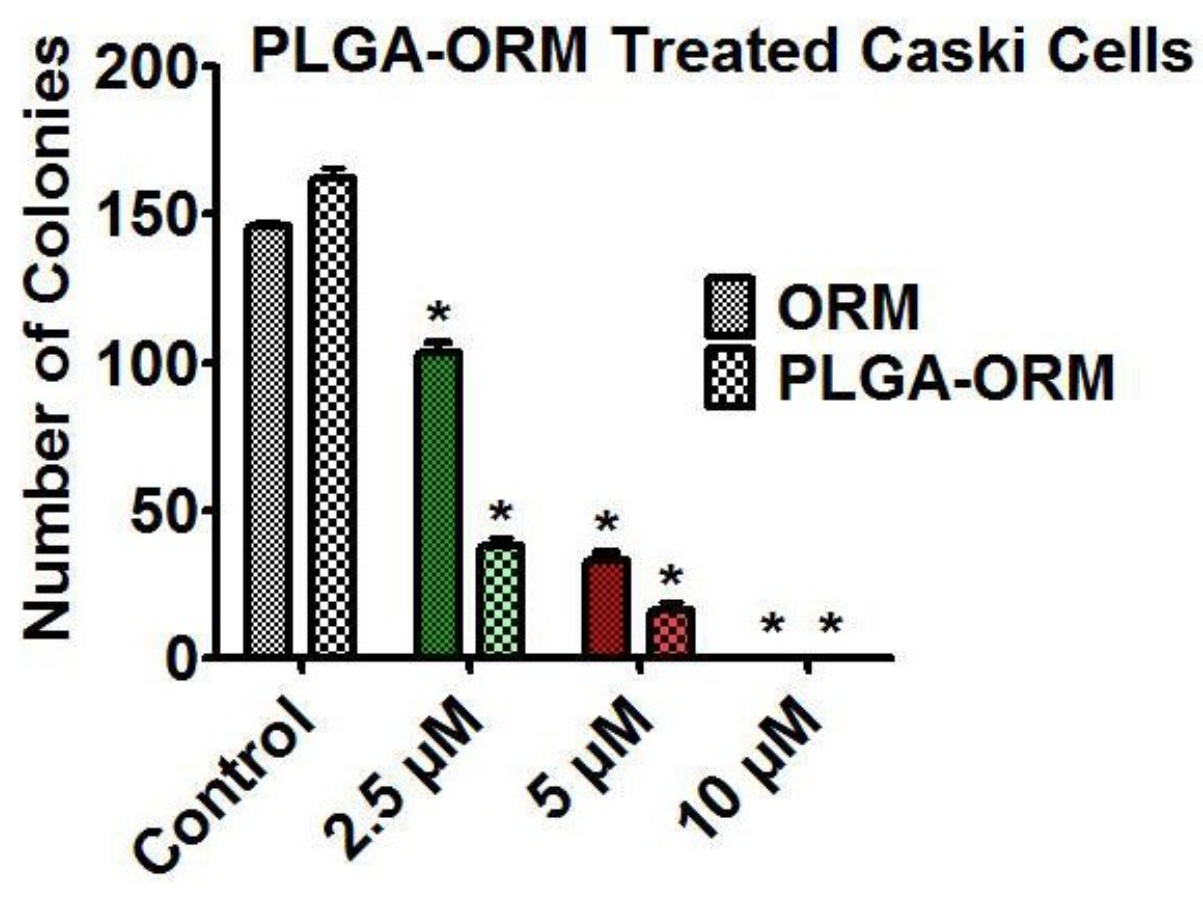

Figure 8-17. Bar graph showing that PLGA-ORM decreased colony forming ability of Caski cells.

Cells were treated with ormeloxifene and PLGA-ORM $(2.5,5$ and $10 \mu \mathrm{M})$ for 14 days. Results were normalized to the vehicle controls (ETOH and PLGA) and free ormeloxifene. Error bars show SEM, $\mathrm{n}=3 .{ }^{*} \mathrm{p}<0.05$.

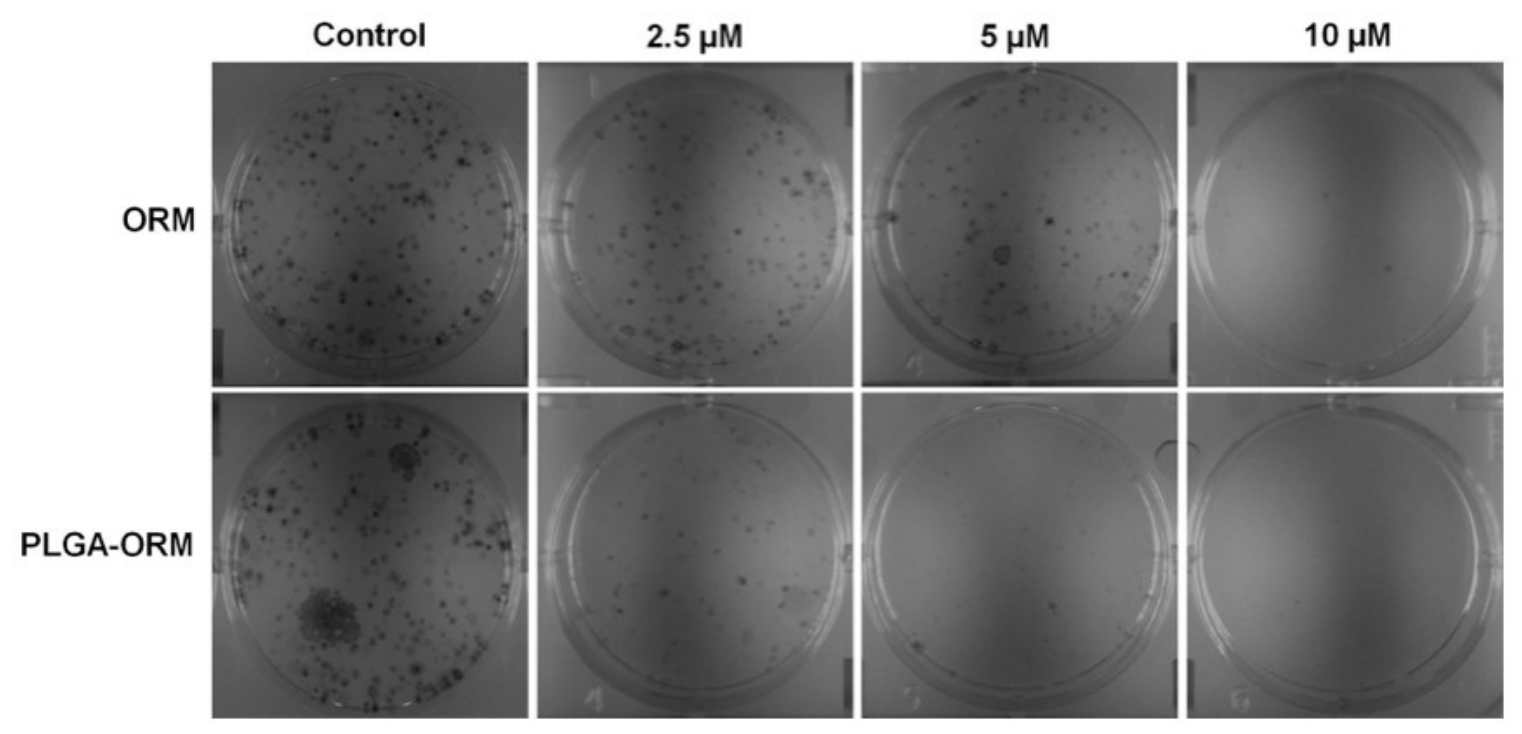

Figure 8-18. PLGA-ORM decreased colony forming ability of SiHa cells. Cells were treated with ormeloxifene and PLGA-ORM $(2.5,5$ and $10 \mu \mathrm{M})$ for 14 days. Images were taken at $200 \mathrm{X}$ using a phase contrast microscope. 


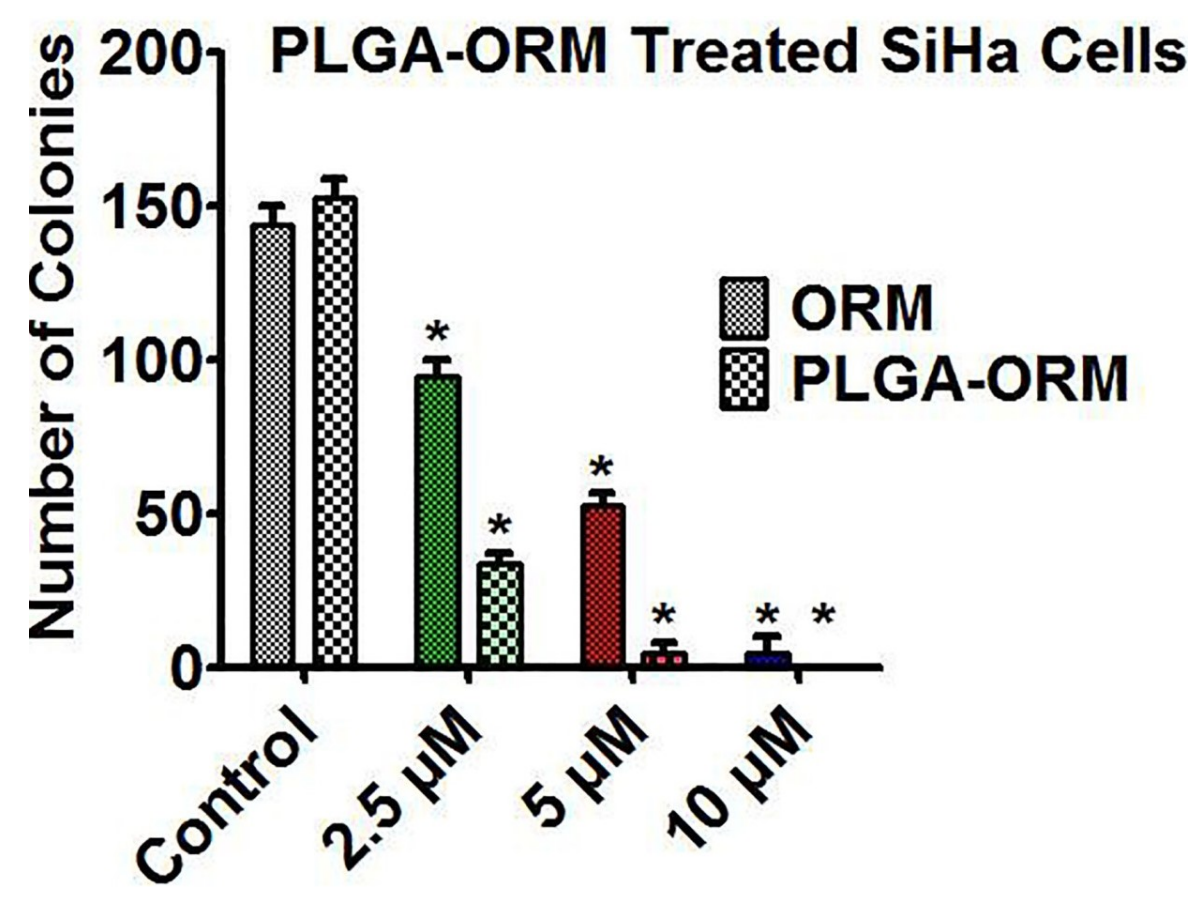

Figure 8-19. Bar graph showing that PLGA-ORM decreased colony forming ability of SiHa cells.

Cells were treated with ormeloxifene and PLGA-ORM $(2.5,5$ and $10 \mu \mathrm{M})$ for 14 days. Results were normalized to the vehicle controls (ETOH and PLGA) and free ormeloxifene. Error bars show SEM, $n=3$. ${ }^{*} \mathrm{p}<0.05$. 


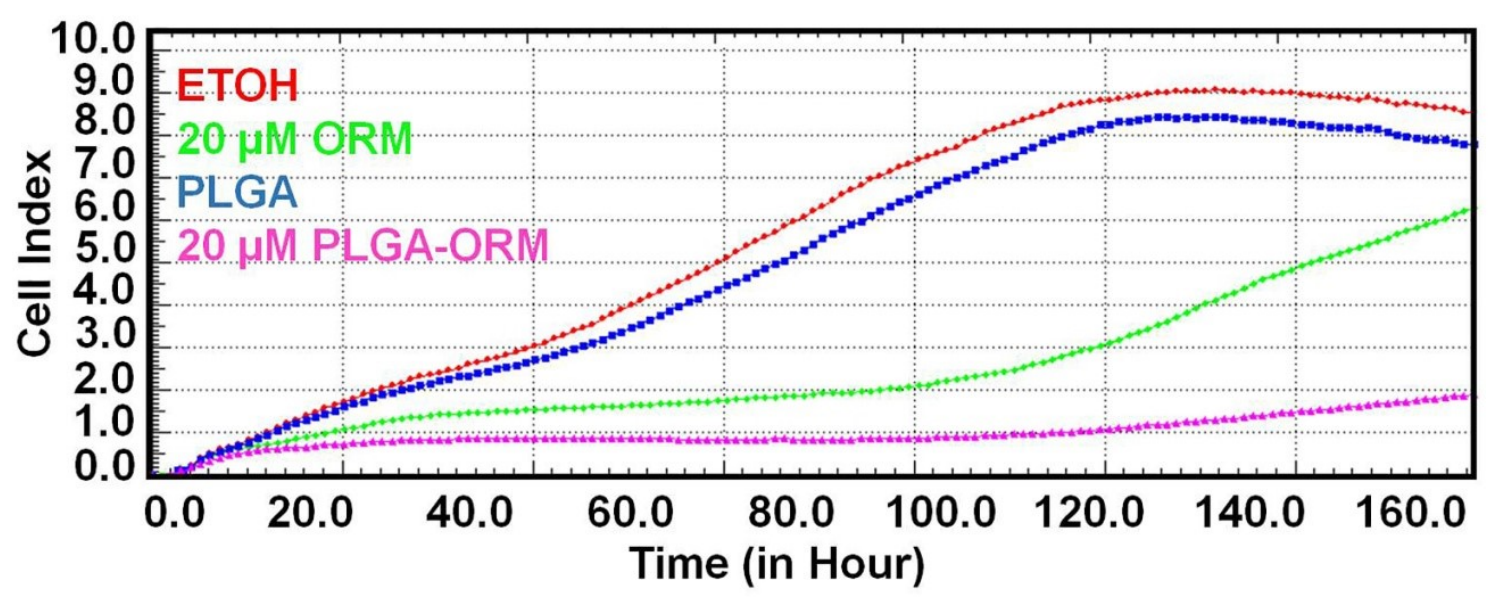

Figure 8-20. PLGA-ORM inhibited growth of Caski cells in real time.

Cells were exposed to ormeloxifene and PLGA-ORM treatments and then measured for real time growth kinetics.

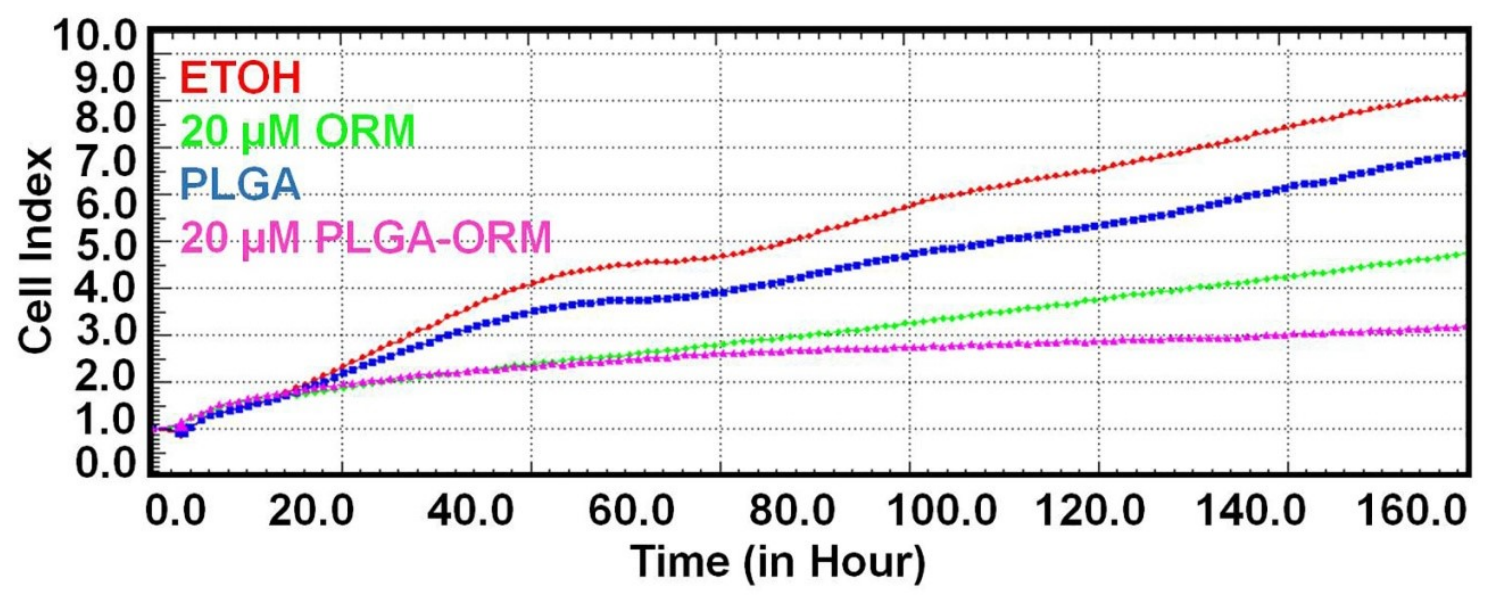

Figure 8-21. PLGA-ORM inhibited growth of SiHa cells in real time.

Cells were exposed to ormeloxifene and PLGA-ORM treatments and then measured for real time growth kinetics. 


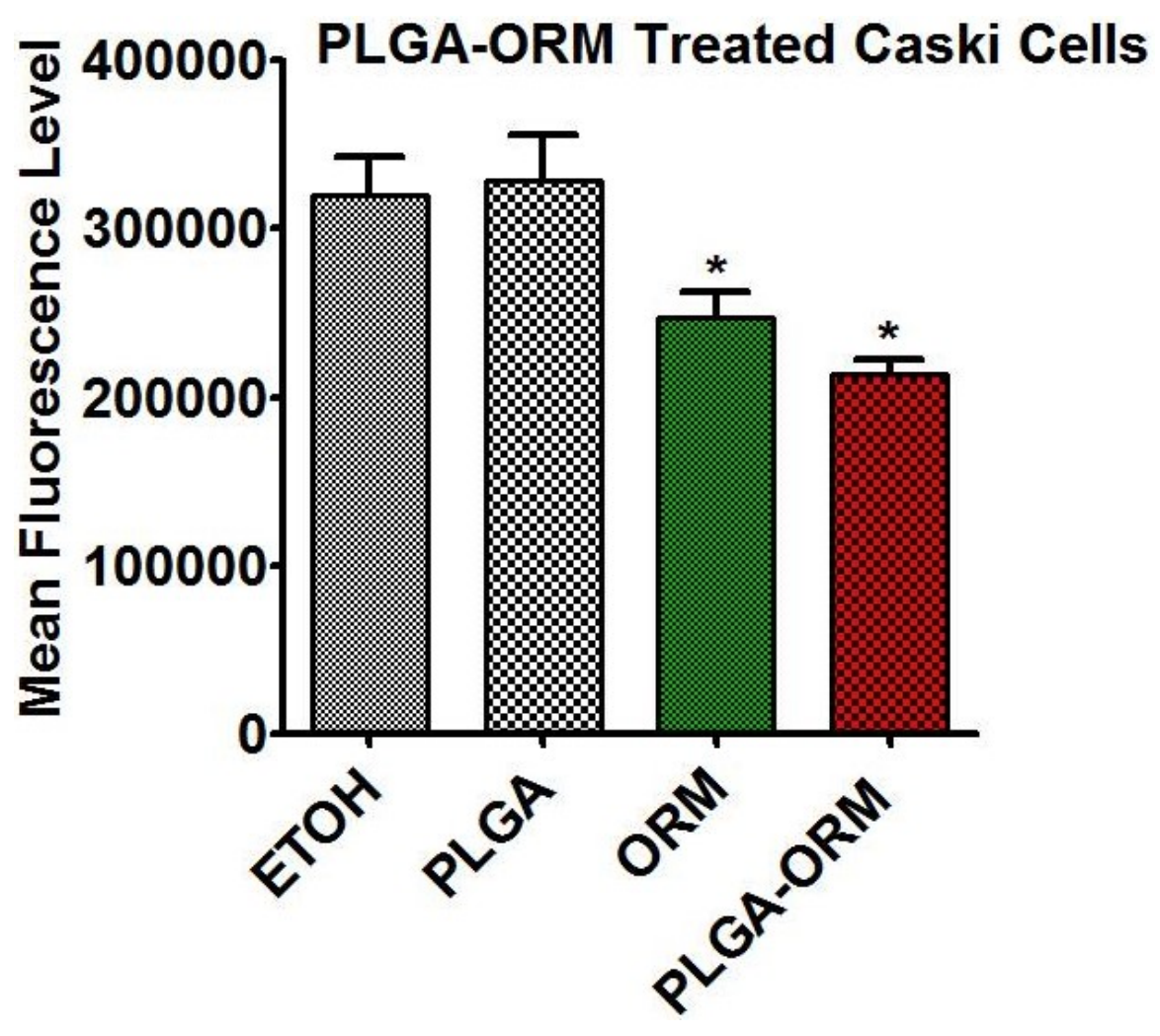

Figure 8-22. PLGA-ORM reduced mitochondrial membrane potential of Caski cells as measured by TMRE stain using flow cytometer.

Cells were treated with ormeloxifene and PLGA-ORM for 24 hours. Results were normalized to the vehicle controls (ETOH and PLGA) and free ormeloxifene. Error bars show SEM, $n=3 . * p<0.05$. 


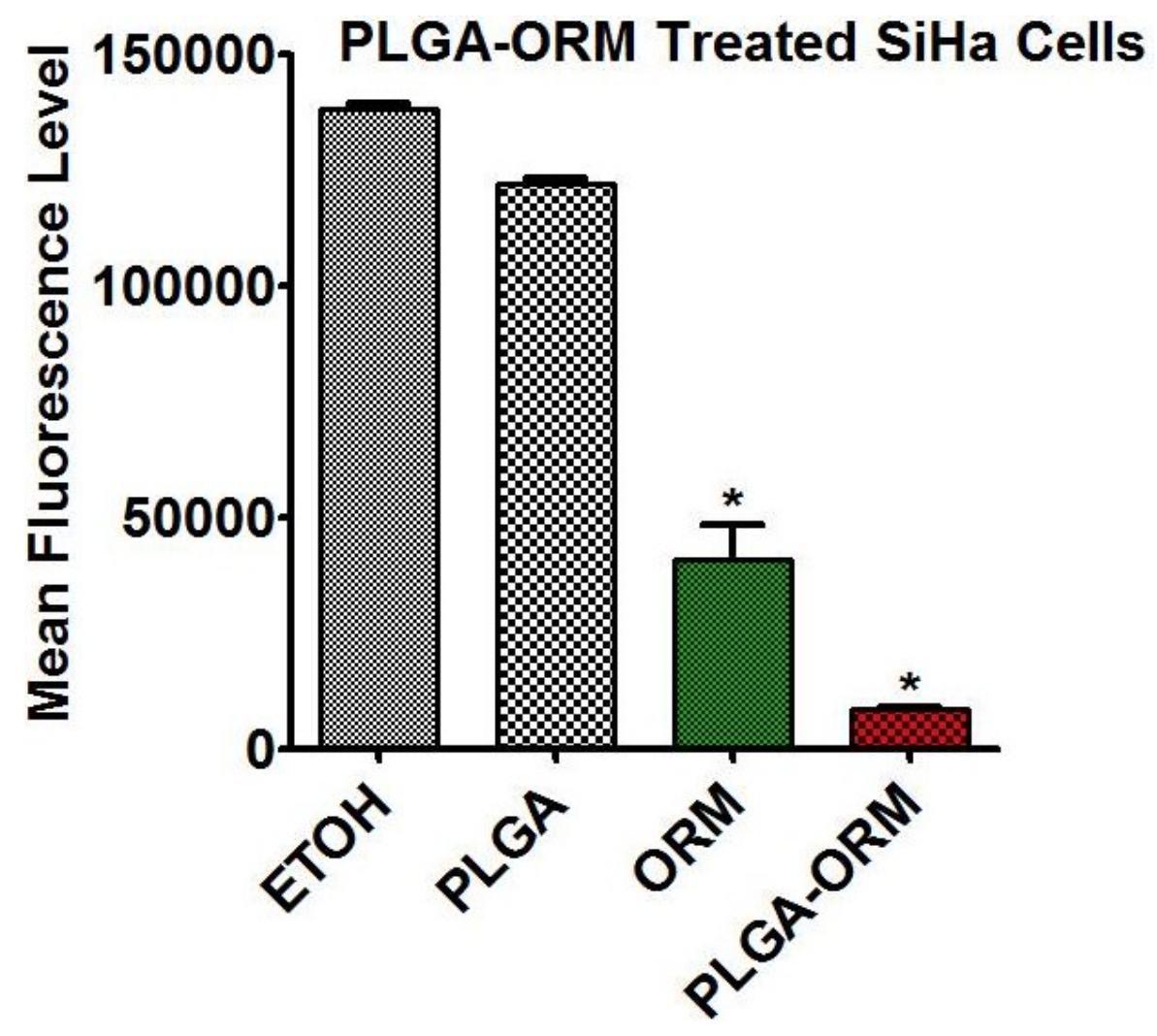

Figure 8-23. PLGA-ORM reduced mitochondrial membrane potential of SiHa cells as measured by TMRE stain using flow cytometer.

Cells were treated with ormeloxifene and PLGA-ORM for 24 hours. Results were normalized to the vehicle controls (ETOH and PLGA) and free ormeloxifene. Error bars show SEM, $n=3 . * p<0.05$. 


\title{
CHAPTER 9. IN VIVO VALIDATION OF ANTI-CANCEROUS/TUMOROUS FUNCTION OF ORMELOXIFENE AND PLGA-ORM
}

\author{
Materials and Methods
}

\section{In vivo Orthotopic Tumoral Study}

In order to study the anti-tumoral properties of ormeloxifene and PLGA-ORM, we developed an orthotopic mice model for cervical cancer (Figure 9-1). 4-6 weeks-old $\mathrm{nu} / \mathrm{nu}$ female mice were purchased from Jackson laboratories and maintained in a pathogen-free environment. HPV positive Caski cervical cancer cells $\left(5 \mathrm{X} 10^{6}\right.$ per mouse) were suspended in PBS and matrigel (BD Bioscience) at a 1:1 ratio. Cell suspension ( $5 \mathrm{X} 10^{6}$ cells in $100 \mu \mathrm{L}$ ) was injected orthotopically direct to the cervix of each mouse. Mice were monitored for the tumor development and once tumor reached the size of around $100 \mathrm{~mm}^{3}$, we started the drug treatment. Mice were treated with free ORM, PLGA-ORM, PBS and PLGA NPs (vehicle controls) at the concentration of 100 $\mu \mathrm{g} /$ mouse (chosen based upon our previous studies in the lab) intraperitoneally (i.p.) for the systemic therapy. Tumor volumes were measured by using a digital vernier caliper and calculated using the formula of tumor volume $\left(\mathrm{mm}^{3}\right)=\pi / 6 \mathrm{x} \mathrm{L} \mathrm{x} \mathrm{W} \mathrm{x} \mathrm{H}$ measured bidimensionally, and survival was noted up to day 40 . Mice survival was analyzed by Kaplan Meir analysis. Mice were sacrificed during the experiment if tumor volume/weight reached more than $10 \%$ of body weight (1.5-2.0 gram) or if mice lost more than $10 \%$ of their total body weight. On day 40 , mice were euthanized and tumors were observed and dissected.

\section{Statistical Analysis}

Statistical analysis was determined by using an unpaired, two tailed student's ttest. The results were considered significant if $P<0.05$. All graphs were generated using GraphPad Prism5 software.

\section{Results}

PLGA-ORM nanoparticles inhibited cervical cancer tumorigenesis in orthotopic mice model. It is imperative to test PLGA-ORM in vivo after seeing its anti-cancerous prosperities in in vitro system. In order to evaluate anti-tumorous efficacy of PLGAORM, we generated an orthotopic cervical cancer mouse model using female nude mice. For this mouse model development, we used HPV positive Caski cervical cancer cells and injected directly into the cervix of these female nude mice. Mice started developing tumors within 15-20 days. Once the tumor size was around $100 \mathrm{~mm}^{3}$, free ORM and PLGA-ORM along with their respective controls PBS and PLGA were administered by 


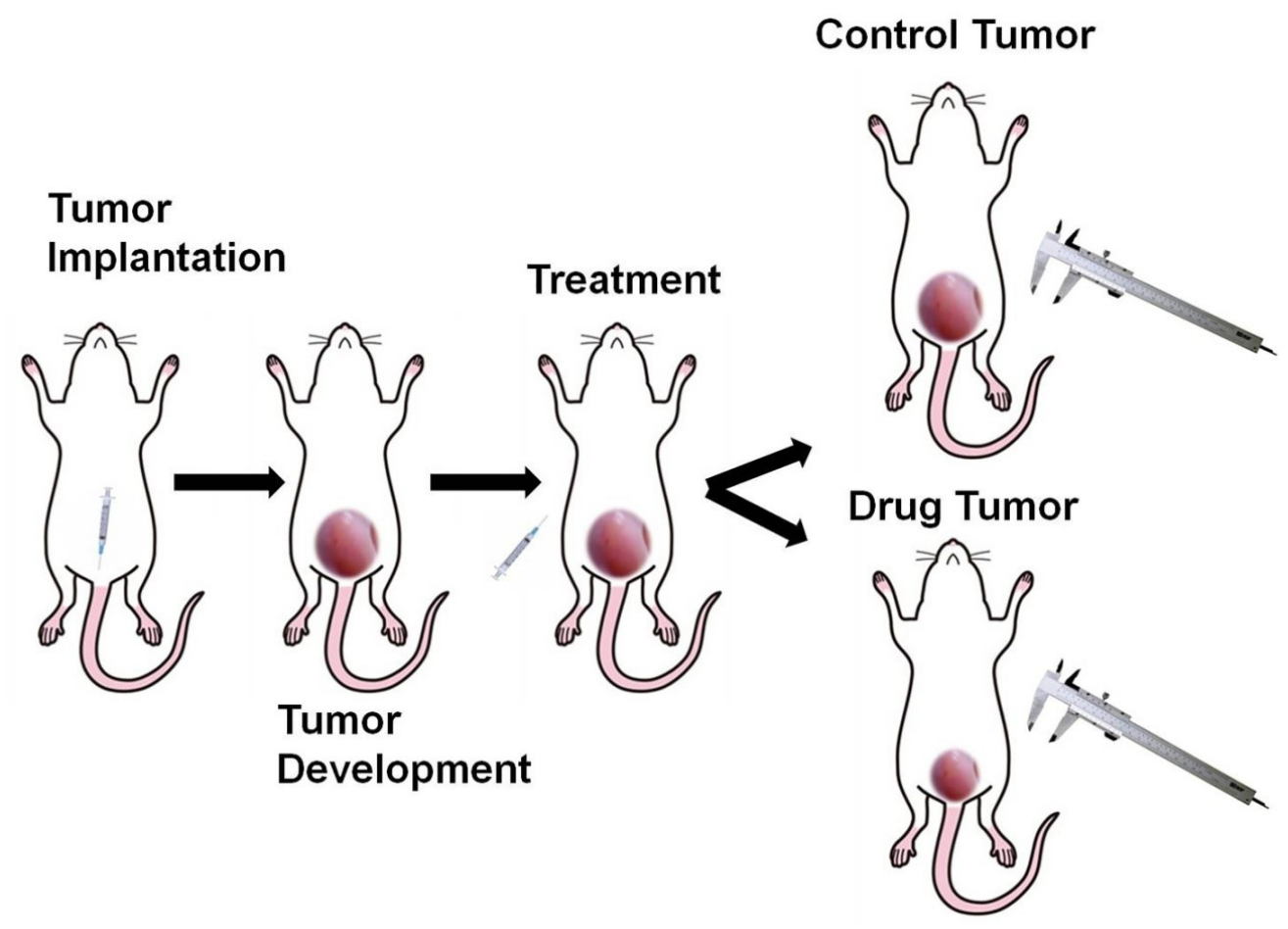

Figure 9-1. Schematic of in vivo study. 
intra-peritoneal injections (Figure 9-1). The study was terminated when the tumor size reached around $1000 \mathrm{~mm}^{3}$, at the termination, mice were euthanized and tumors were dissected from all groups (Figure 9-2). During the entire study tumor size/volume was measured. ORM and PLGA-ORM significantly decreased the tumor volume when compared to their respective controls (Figure 9.3). We also measured the tumor weight after dissection and results suggested that ORM and PLGA-ORM reduced the tumor weight markedly when compared to their controls (Figure 9-4). Interestingly, PLGAORM had more inhibitory effect on tumor size and weight than that observed with free ORM (Figure 9-3 and Figure 9-4). After further validation, it was observed that ORM and PLGA-ORM also increased the overall mice survival rate (Figure 9-5).
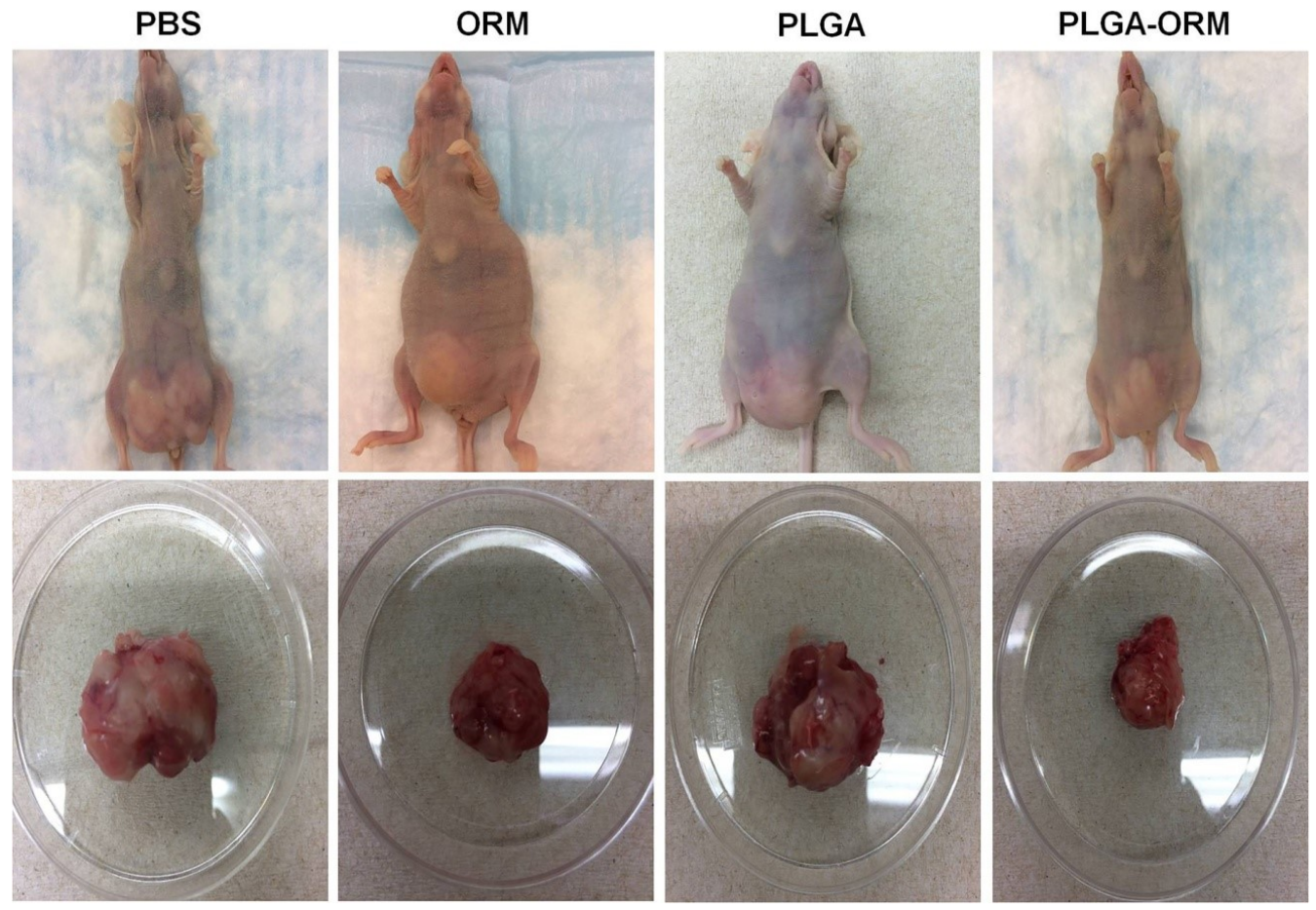

Figure 9-2. Images represent mice from different treatment groups and their dissected tumors 


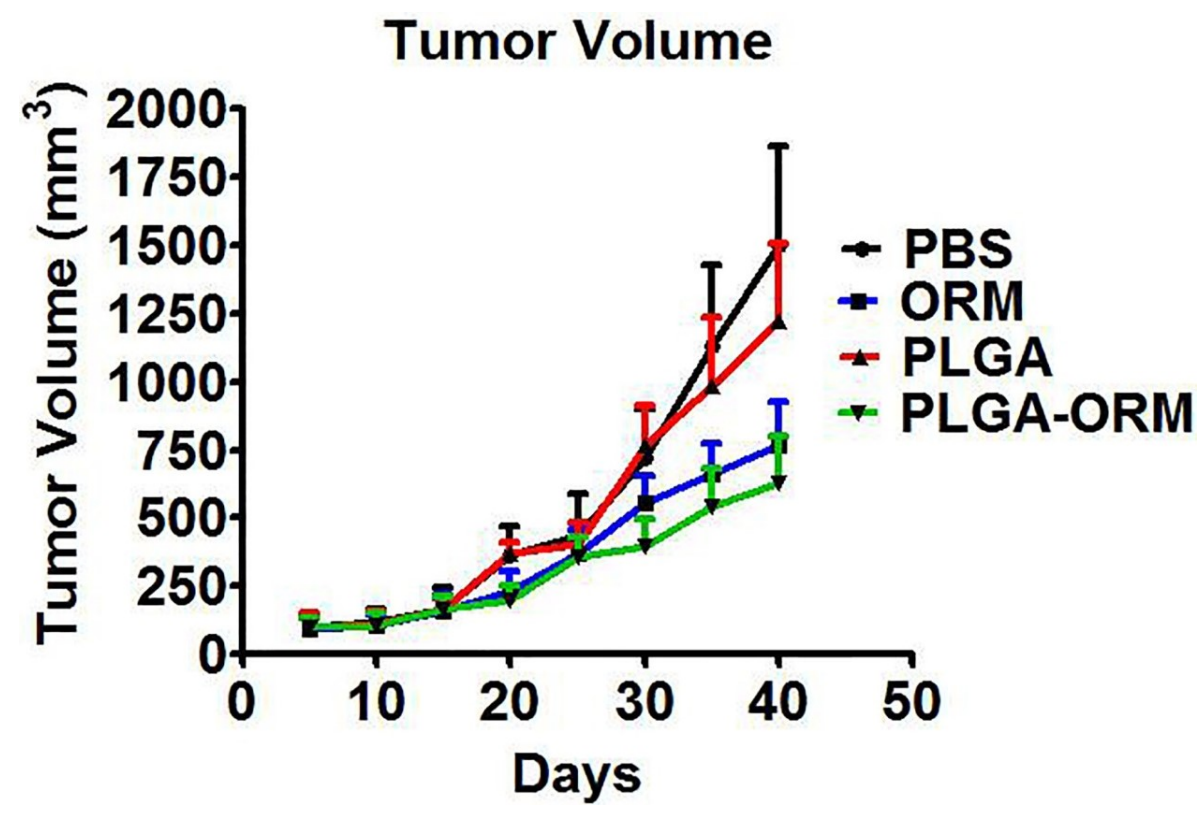

Figure 9-3. PLGA-ORM inhibited tumor growth of cervical cancer orthotopic mice model.

Average tumor volume of ormeloxifene and PLGA-ORM treated mice. Error bars show $\mathrm{SEM}, \mathrm{n}=6$. 


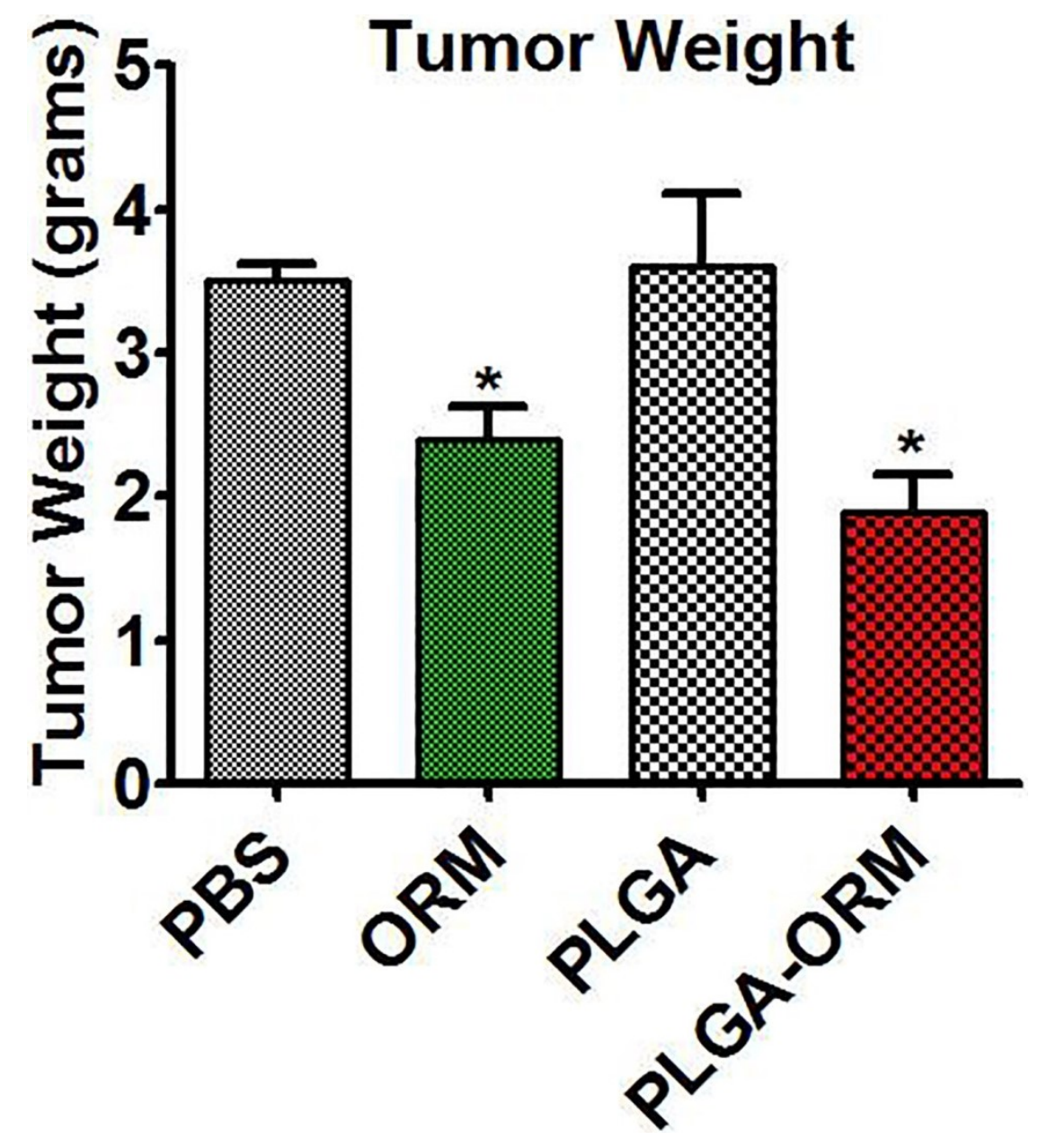

Figure 9-4. Weight measurement from the tumors dissected from mice.

ORM and PLGA-ORM significantly reduced the tumor weight when compared to their respective vehicle controls PBS and PLGA, Error bars show SEM, n=6. * $<<0.05$. 


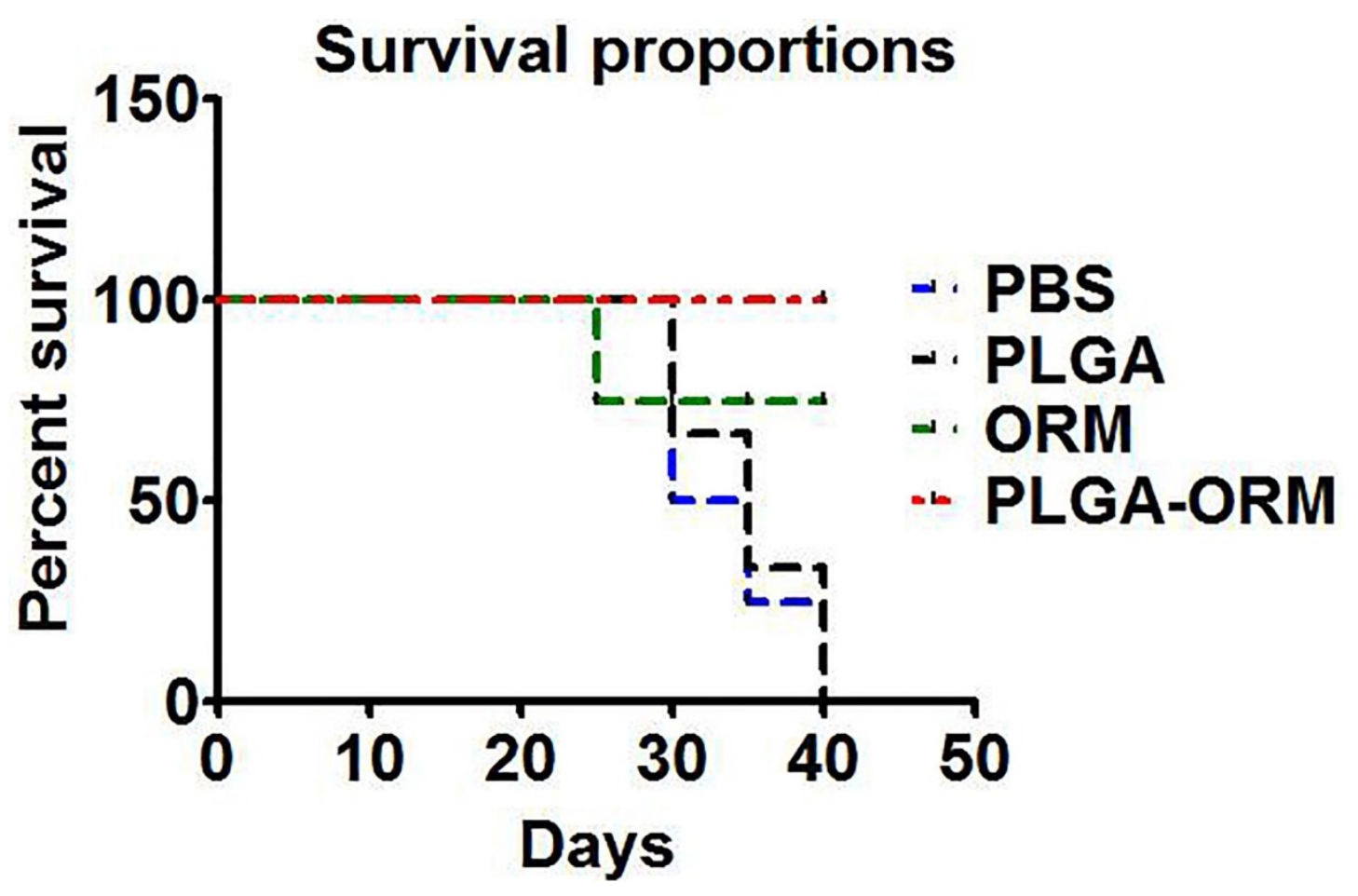

Figure 9-5. Percent survival curve for ORM and PLGA-ORM treated mice. PLGA-ORM (Red Line) showed the 100\% survival over other groups. 


\section{CHAPTER 10. DISCUSSION*}

Despite of having various preventative modalities including vaccines and screening, advanced stage cervical cancer is a deadly malignancy in women. Advanced stages of cervical cancer remain untreatable as a result of many modulations at the cellular and molecular level. Cells become more motile/ invasive and show resistance towards chemo and radiotherapy. Thus, newer therapeutic modalities are highly desirable that may provide protection against metastasis and chemo/radio-resistance. In the modern research world, repurposing of already in use molecules has become a new attraction. Considering the potential of repurposing a drug that is in use already, we investigated the therapeutic potential of ormeloxifene in this study. Ormeloxifene has been used for its birth control purposes for more than last two decades in India. Ormeloxifene targets high proliferative decidual cells in the endometrium and it is reported safe to use. Recently, studies from other groups as well as our lab have demonstrated that ormeloxifene has anti-cancerous activities against breast, head and neck, ovarian, pancreatic and leukemia cancers.

Uncontrolled cell proliferation/ growth and inability to have programmed cell death are the major causes of cancer development. In this study we show that ormeloxifene decreases cellular proliferation of four different cells, both HPV positive and negative with a short term (48 hrs) treatment of ormeloxifene at micro-molar concentrations confirmed by MTS assay. Results from xCELLigence real time growth kinetic assay are also consistent with MTS data findings. Ormeloxifene also inhibits the clonogenic potential of all four cell lines with a long term treatment of about 14/15 days. Results are consistent with previous work on ormeloxifene's anti-proliferative potential. Upon the drug treatment, cells exhibit clear signs of apoptosis. Ormeloxifene treatment alters the morphology of Caski and SiHa cells and shows the apoptosis like signs such as membrane blebbing, cell shrinkage and round of shape. Apoptosis is a major event that occurs in response to many anti-cancer drugs. Apoptosis consists of two different pathways, namely extrinsic and intrinsic. Intrinsic apoptotic death cascade involves the depolarization of mitochondrial membrane as a first event of the cascade that further leads to activation of Caspase and results in PARP cleavage. Ormeloxifene treatment for 24 hours affects the mitochondrial membrane depolarization as confirmed by decreased mitochondrial membrane potential assessed by TMRE staining through fluorescent microscopy and flow cytometer. Annexin V-7AAD staining is another method to detect the apoptotic cell population. Ormeloxifene treatment for 24 hours results in increased apoptotic population of Caski and $\mathrm{SiHa}$ cells which indicates that ormeloxifene has a potential to become anti-proliferative/growth molecule for cervical cancer.

Excessive cell cycle progression is a key property of cancerous cells and controlled by many activated cyclins and their dependent kinase. Ormeloxifene treatment

* Adapted with permission. Khan, S., et al., Nanoparticle formulation of ormeloxifene for pancreatic cancer. Biomaterials, 2015. 53: p. 731-743. 
plays an inhibitory role in cell cycle progression of Caski and SiHa cells. It arrests cell cycle in both cell lines at G1-S transition and decreases the expression of Cyclin E and its dependent kinase CDk2. Cyclin E and cdk2 help cells to progress from G1 phase to S phase. PI3K-Akt pathways play an important role in cell growth and cell cycle progression. In accordance with previous findings, we show that ormeloxifene downregulates the PI3K-Akt pathway in cervical cancer cells as shown by decreased expression levels of PI3K and Akt, and increased phosphorylation of Akt. Ormeloxifene further decreases the downstream target of PI3K-Akt pathway, p21, a known inhibitor of cell cycle progression. Cancer cells show enhanced motility and invasion which helps cancer cells migrate from one organ to another and this is how cancer spreads. Molecules that inhibit migratory and invasive property of cancer cells are the strong candidates for having anti-cancerous properties. We utilized various techniques including agarose bead assay, Boyden chamber migration, invasion assay and real time migration/invasion by xCELLigence to confirm ormeloxifene's effect on motility of Caski and SiHa cell lines. Results reveal that cells become less motile and invasive with ormeloxifene treatment for 24 hours.

Persistent HPV infection is required for the progression of cervical cancer so we intended to assess ormeloxifene's effect on HPV E6 and E7 expression. Ormeloxifene successfully inhibits the mRNA levels of HPV E6 and E7 with 6 hours of treatment; the downregulation also continued to the translational levels as ormeloxifene decreases the expression of HPV E6 and E7 oncoproteins with 24 hours treatment. HPV E6 and E7 deregulate the cell cycle by inactivating tumor suppressor proteins $\mathrm{p} 53$, Rb and PTPN13; interestingly, ormeloxifene unregulated the expression of these three proteins. These findings suggest that ormeloxifene not only decreases the oncogenic signaling but also increases the tumor suppressing signaling, thus, demonstrates potent anti-HPV properties in cervical cancer cells.

Ormeloxifene also sensitized Caski cervical cancer cells to radiation. Data showed that pre-treatment of ormeloxifene ( 24 hours prior to radiation exposure for proliferation and 6 hours prior for colony formation) had better and improved growth inhibitory effects on cells when compared with ormeloxifene and radiation alone.

Ormeloxifene is a synthetic molecule which is widely used as an oral contraceptive in humans and exhibits potent anti-cancer activity by targeting the key underlying oncogenic molecular mechanisms [198-205]. Hence, our aim of this study was to enhance ORM delivery at the tumor site for improved therapeutic effects/index for cervical cancer treatment. To this end, we have developed an efficient PLGA NP (PLGAORM NP) based delivery system, to enhance the anti-cancer efficiency of ORM at the tumor site. In the present study, an optimized PLGA-ORM 20 NP formulation was made with an average particle size of $101.4 \pm 1.5 \mathrm{~nm}$ with $84.96 \pm 4.75 \%$ drug-loading capacity. This formulation provides good suspension while maintaining long-term stability, up to 6 months. From the results of FT-IR, DSC, and TGA, it is evident that PLGA, PVA, and PLL polymers form undefined structure in PLGA-ORM NPs, which allow for the controlled release in cancer cells. We observed that PLGA-ORM NPs delivered a higher payload of ORM in cervical cancer cells which was correlated with the 
increased cytotoxicity in cervical cancer cells. Elucidating the internalization mechanisms could provide crucial insights into engineering novel cancer therapeutics yielding more potent and selective nanoformulations. The uptake and internalization of PLGA-ORM NPs follow an endocytotic pathway, which is consistent with most of the conventional nanoformulations [206].

This study with PLGA-ORM NPs demonstrates enhanced anti-cancer effects over free ORM against four different cervical cancer cell lines in proliferation and clonogenic potential assays. Additionally, PLGA-ORM induces apoptosis in cervical cancer cells. From a clinical translational point of view, achieving the highest drug loading is more favorable for clinical use to improve pharmacokinetic profiles. Therefore, we have engineered an optimized PLGA-ORM20 NP formulation with higher loading capacity. The higher drug loading not only minimizes (i) processing, (ii) overall raw materials, and (iii) non-active ingredients for generating the formulation, but efficiently delivers an equivalent dose of ORM. Overall, in this proof-of-concept study, we have demonstrated that PLGA-ORM20 NP formulation is highly suitable to deliver ORM more efficiently at the tumor site to induce superior anti-cancer activity.

After discussing all the outcomes of this work, it can be said that the central hypothesis and the questions asked, were completely justified in this dissertation work. This dissertation work provides an insight on an upcoming repurposed molecule that has great potential to become an anti-cervical cancer agent. This work holds substantial promises for future, thus, needs to be continued in order to further understand the underlying mechanisms of these results. Our data indicated that PI3K-Akt which is one of the main stream pathways involved in cervical cancer carcinogenesis is inhibited by ormeloxifene so further work is required to establish this pathway as the mechanism of action for ormeloxifene in cervical cancer. Our combination therapy data with ormeloxifene and radiation on proliferation/growth studies also exhibited excellent outcomes. This work certainly needs to be carried forward in future where it can be tested in vitro and in vivo to investigate a combination therapy for cervical cancer management. Also, the in vitro and in vivo studies with nanoformulation of ormeloxifene revealed its future commercial prospective. Summing up, this dissertation work holds a considerable potential to be extended in future and to be continued in translational settings. 


\section{LIST OF REFERENCES}

1. Ferlay, J., et al., Cancer incidence and mortality worldwide: sources, methods and major patterns in GLOBOCAN 2012. International Journal of Cancer, 2015. 136(5): p. E359-E386.

2. Boffetta, P. and D.M. Parkin, Cancer in developing countries. CA: a cancer journal for clinicians, 1994. 44(2): p. 81-90.

3. Denny, L., M. Quinn, and R. Sankaranarayanan, Screening for cervical cancer in developing countries. Vaccine, 2006. 24: p. S71-S77.

4. $\quad$ Parkin, D., Cancer in developing countries. Cancer surveys, 1993. 19: p. 519-561.

5. Reid, J., Women's knowledge of Pap smears, risk factors for cervical cancer, and cervical cancer. Journal of Obstetric, Gynecologic, \& Neonatal Nursing, 2001. 30(3): p. 299-305.

6. MM wALBooMER, J., et al., HUMAN PAPILLOMAVIRUS IS A NECESSARY CAUSE OF INVASIVE CERVICAL CANCER. VVORLDWIDE. J. pathol, 1999. 189: p. 12-19.

7. Bosch, F.X. and S. De Sanjosé, Human papillomavirus and cervical cancer-burden and assessment of causality. Journal of the National Cancer Institute. Monographs, 2002(31): p. 3-13.

8. Bosch, F., et al., The causal relation between human papillomavirus and cervical cancer. Journal of clinical pathology, 2002. 55(4): p. 244-265.

9. Clifford, G., et al., Human papillomavirus types in invasive cervical cancer worldwide: a meta-analysis. British journal of cancer, 2003. 88(1): p. 63-73.

10. Zur Hausen, H., Papillomavirus infections-a major cause of human cancers. Biochimica et Biophysica Acta (BBA)-Reviews on Cancer, 1996. 1288(2): p. F55-F78.

11. Zhao, K.N. and J. Chen, Codon usage roles in human papillomavirus. Reviews in medical virology, 2011. 21(6): p. 397-411.

12. Gardiol, D., et al., Oncogenic human papillomavirus E6 proteins target the discs large tumour suppressor for proteasome-mediated degradation. Oncogene, 1999. 18(40). 
13. Dang, J., et al., Oral Human Papillomavirus (HPV) Infection in Healthy Individuals and Patients with Head and Neck Squamous Cell Carcinoma (HNSCC). Epidemiology (sunnyvale), 2015. 5(180): p. 2161-1165.1000180.

14. Yugawa, T. and T. Kiyono, Molecular mechanisms of cervical carcinogenesis by high-risk human papillomaviruses: novel functions of E6 and E7 oncoproteins. Reviews in medical virology, 2009. 19(2): p. 97-113.

15. Kjaer, S.K., et al., High-risk human papillomavirus is sexually transmitted: evidence from a follow-up study of virgins starting sexual activity (intercourse). Cancer Epidemiology Biomarkers \& Prevention, 2001. 10(2): p. 101-106.

16. Bosch, F.X., et al., Prevalence of human papillomavirus in cervical cancer: a worldwide perspective. Journal of the National Cancer Institute, 1995. 87(11): p. 796-802.

17. Chichareon, S., et al., Risk factors for cervical cancer in Thailand: a case-control study. Journal of the National Cancer Institute, 1998. 90(1): p. 50-57.

18. De Villiers, E.-M., et al., Classification of papillomaviruses. Virology, 2004. 324(1): p. 17-27.

19. Cogliano, V., et al., Carcinogenicity of human papillomaviruses. The lancet oncology, 2005. 6(4): p. 204.

20. Sigmund, C., et al., Viruses in human cancers. Oncogene, 1990. 5: p. 1507.

21. Smola, S., Human Papilloma Viruses and Skin Cancer, in Sunlight, Vitamin D and Skin Cancer. 2014, Springer. p. 192-207.

22. Lacey, C.J., C.M. Lowndes, and K.V. Shah, Burden and management of noncancerous HPV-related conditions: HPV-6/11 disease. Vaccine, 2006. 24: p. S35S41.

23. Gross, G. and H. Pfister, Role of human papillomavirus in penile cancer, penile intraepithelial squamous cell neoplasias and in genital warts. Medical microbiology and immunology, 2004. 193(1): p. 35-44.

24. Smith, J.S., et al., Human papillomavirus type distribution in invasive cervical cancer and high-grade cervical lesions: A meta-analysis update. International journal of cancer, 2007. 121(3): p. 621-632.

25. Thomas, L.K., et al., Chromosomal gains and losses in human papillomavirusassociated neoplasia of the lower genital tract-a systematic review and metaanalysis. European Journal of Cancer, 2014. 50(1): p. 85-98. 
26. Ojesina, A.I., et al., Landscape of genomic alterations in cervical carcinomas. Nature, 2014. 506(7488): p. 371-375.

27. Stubenrauch, F. and L.A. Laimins. Human papillomavirus life cycle: active and latent phases. in Seminars in cancer biology. 1999. Elsevier.

28. Maglennon, G.A. and J. Doorbar, The biology of papillomavirus latency. The open virology journal, 2012. 6(1).

29. Moody, C.A. and L.A. Laimins, Human papillomaviruses activate the ATM DNA damage pathway for viral genome amplification upon differentiation. PLoS Pathog, 2009. 5(10): p. e1000605.

30. Zur Hausen, H., Papillomaviruses and cancer: from basic studies to clinical application. Nature Reviews Cancer, 2002. 2(5): p. 342-350.

31. Doorbar, J., Papillomavirus life cycle organization and biomarker selection. Disease markers, 2007. 23(4): p. 297-313.

32. Oh, S.T., M.S. Longworth, and L.A. Laimins, Roles of the E6 and 67 proteins in the life cycle of low-risk human papillomavirus type 11. Journal of virology, 2004. 78(5): p. 2620-2626.

33. Pyeon, D., et al., Establishment of human papillomavirus infection requires cell cycle progression. PLoS Pathog, 2009. 5(2): p. e1000318.

34. Hawley-Nelson, P., et al., HPV16 E6 and E7 proteins cooperate to immortalize human foreskin keratinocytes. The EMBO journal, 1989. 8(12): p. 3905.

35. Scheffner, M., et al., The E6 oncoprotein encoded by human papillomavirus types 16 and 18 promotes the degradation of $p 53$. Cell, 1990. 63(6): p. 1129-1136.

36. Scheffner, M., et al., The HPV-16 E6 and E6-AP complex functions as a ubiquitin-protein ligase in the ubiquitination of p53. Cell, 1993. 75(3): p. 495505.

37. Zerfass, K., et al., Sequential activation of cyclin E and cyclin A gene expression by human papillomavirus type 16 E7 through sequences necessary for transformation. Journal of virology, 1995. 69(10): p. 6389-6399.

38. Chellappan, S., et al., Adenovirus E1A, simian virus 40 tumor antigen, and human papillomavirus $E 7$ protein share the capacity to disrupt the interaction between transcription factor E2F and the retinoblastoma gene product. Proceedings of the National Academy of Sciences, 1992. 89(10): p. 4549-4553. 
39. Cobrinik, D., et al., The retinoblastoma protein and the regulation of cell cycling. Trends in biochemical sciences, 1992. 17(8): p. 312-315.

40. Nevins, J.R., E2F: a link between the Rb tumor suppressor protein and viral oncoproteins. SCIENCE-NEW YORK THEN WASHINGTON-, 1992. 258: p. 424-424.

41. Boxem, M., Cyclin-dependent kinases in C. elegans. Cell division, 2006. 1(1): p. 6.

42. Dehay, C. and H. Kennedy, Cell-cycle control and cortical development. Nature Reviews Neuroscience, 2007. 8(6): p. 438-450.

43. Spanos, W.C., et al., The PDZ binding motif of human papillomavirus type 16 E6 induces PTPN13 loss, which allows anchorage-independent growth and synergizes with ras for invasive growth. Journal of virology, 2008. 82(5): p. 24932500.

44. Castellsagué, X. and N. Muñoz, Cofactors in human papillomavirus carcinogenesis-role of parity, oral contraceptives, and tobacco smoking. J Natl Cancer Inst Monogr, 2003. 31: p. 20-8.

45. GAITAN, E., B.M. GARCIA, and W.E. RAWLS, Sexual behavior, venereal diseases, hygiene practices, and invasive cervical cancer in a high-risk population. Cancer, 1990. 65380: p. 386.

46. CLARKE, E.A., R.W. MORGAN, and A.M. NEWMAN, Smoking as a risk factor in cancer of the cervix: additional evidence from a case-control study. American journal of epidemiology, 1982. 115(1): p. 59-66.

47. Brinton, L.A., et al., Sexual and reproductive risk factors for invasive squamous cell cervical cancer. Journal of the National Cancer Institute, 1987. 79(1): p. 2330 .

48. Santos, C., et al., HPV types and cofactors causing cervical cancer in Peru. British Journal of Cancer, 2001. 85(7): p. 966.

49. Shields, T.S., et al., A case-control study of risk factors for invasive cervical cancer among US women exposed to oncogenic types of human papillomavirus. Cancer Epidemiology Biomarkers \& Prevention, 2004. 13(10): p. 1574-1582.

50. Moreno, V., et al., Effect of oral contraceptives on risk of cervical cancer in women with human papillomavirus infection: the IARC multicentric case-control study. The Lancet, 2002. 359(9312): p. 1085-1092. 
51. BRINTON, L.A., et al., Oral contraceptive use and risk of invasive cervical cancer. International journal of epidemiology, 1990. 19(1): p. 4-11.

52. Hildesheim, A., et al., Association of oral contraceptive use and human papillomaviruses in invasive cervical cancers. International Journal of Cancer, 1990. 45(5): p. 860-864.

53. Beral, V., P. Hannaford, and C. Kay, Oral contraceptive use and malignancies of the genital tract: results from the Royal College of General Practitioners' Oral Contraception Study. The Lancet, 1988. 332(8624): p. 1331-1335.

54. Janicek, M.F. and H.E. Averette, Cervical cancer: prevention, diagnosis, and therapeutics. CA: a cancer journal for clinicians, 2001. 51(2): p. 92-114.

55. Brinton, L.A., et al., Cigarette smoking and invasive cervical cancer. Jama, 1986. 255(23): p. 3265-3269.

56. Slattery, M.L., et al., Cigarette smoking and exposure to passive smoke are risk factors for cervical cancer. Jama, 1989. 261(11): p. 1593-1598.

57. Maher, D.M., et al., Curcumin suppresses human papillomavirus oncoproteins, restores $p 53, r b$, and ptpn 13 proteins and inhibits benzo [a] pyrene-induced upregulation of HPV E7. Molecular carcinogenesis, 2011. 50(1): p. 47-57.

58. Burger, M., et al., Cigarette smoking and human papillomavirus in patients with reported cervical cytological abnormality. Bmj, 1993. 306(6880): p. 749-752.

59. Schiffman, M.H., et al., Biochemical epidemiology of cervical neoplasia: Measuring cigarette smoke constitutents in the cervix. Cancer research, 1987. 47(14): p. 3886-3888.

60. Prokopczyk, B., J.E. Cox, and D. Hoffmann, Identification of tobacco-specific carcinogen in the cervical mucus of smokers and nonsmokers. Journal of the National Cancer Institute, 1997. 89(12): p. 868-873.

61. Clarke, P., et al., The psychosocial impact of human papillomavirus infection: implications for health care providers. International journal of STD \& AIDS, 1996. 7(3): p. 197-200.

62. Collins, S., et al., High incidence of cervical human papillomavirus infection in women during their first sexual relationship. BJOG: an International Journal of Obstetrics \& Gynaecology, 2002. 109(1): p. 96-98.

63. Sethi, S., et al., Serologic response to the E4, E6, and E7 proteins of human papillomavirus type 16 in pregnant women. American journal of obstetrics and gynecology, 1998. 178(2): p. 360-364. 
64. Chung, S.-H., et al., Requirement for estrogen receptor $\alpha$ in a mouse model for human papillomavirus-associated cervical cancer. Cancer research, 2008. 68(23): p. 9928-9934.

65. Burd, E.M., Human papillomavirus and cervical cancer. Clinical microbiology reviews, 2003. 16(1): p. 1-17.

66. Wu, J., et al., Four Major Factors Regulate Phosphatidylinositol 3-kinase Signaling Pathway in Cancers Induced by Infection of Human Papillomaviruses. Current medicinal chemistry, 2014. 21(26): p. 3057-3069.

67. Jimeno, A. Molecular pathways in head and neck cancer: EGFR, PI3K, and more. 2013. American Society of Clinical Oncology.

68. Won, H.S., et al., Difference in expression of EGFR, pAkt, and PTEN between oropharyngeal and oral cavity squamous cell carcinoma. Oral oncology, 2012. 48(10): p. 985-990.

69. Zhang, E., et al., Roles of PI3K/Akt and c-Jun signaling pathways in human papillomavirus type 16 oncoprotein-induced HIF-1 $\alpha, V E G F$, and IL-8 expression and in vitro angiogenesis in non-small cell lung cancer cells. PLoS One, 2014. 9(7): p. e103440.

70. Menges, C.W., et al., Human papillomavirus type 16 E7 up-regulates AKT activity through the retinoblastoma protein. Cancer research, 2006. 66(11): p. 5555-5559.

71. Lee, C.M., et al., Phosphatidylinositol 3-kinase inhibition by LY294002 radiosensitizes human cervical cancer cell lines. Clinical cancer research, 2006. 12(1): p. 250-256.

72. McAuliffe, P.F., et al., Deciphering the role of PI3K/Akt/mTOR pathway in breast cancer biology and pathogenesis. Clinical breast cancer, 2010. 10: p. S59-S65.

73. Yao, R. and G.M. Cooper, Requirement for phosphatidylinositol-3 kinase in the prevention of apoptosis by nerve growth factor. Science, 1995. 267(5206): p. 2003.

74. Kauffmann-Zeh, A., et al., Suppression of c-Myc-induced apoptosis by Ras signalling through PI (3) K and PKB. 1997.

75. Liu, X., et al., Exonic splicing enhancer-dependent selection of the bovine papillomavirus type 1 nucleotide 3225 3' splice site can be rescued in a cell lacking splicing factor ASF/SF2 through activation of the phosphatidylinositol 3kinase/Akt pathway. Journal of virology, 2003. 77(3): p. 2105-2115. 
76. McFarlane, M. and S.V. Graham, Human papillomavirus regulation of SR proteins. Biochemical Society transactions, 2010. 38(4): p. 1116-1121.

77. Crook, T., et al., Continued expression of HPV-16 E7 protein is required for maintenance of the transformed phenotype of cells co-transformed by HPV-16 plus EJ-ras. The EMBO journal, 1989. 8(2): p. 513.

78. Veeraraghavalu, K., et al., Complementation of human papillomavirus type 16 E6 and E7 by Jagged1-specific Notch1-phosphatidylinositol 3-kinase signaling involves pleiotropic oncogenic functions independent of CBF1; Su (H); Lag-1 activation. Journal of virology, 2005. 79(12): p. 7889-7898.

79. Patel, H., et al., Activation of AKT and nuclear accumulation of wild type TP53 and MDM2 in anal squamous cell carcinoma. International Journal of Cancer, 2007. 121(12): p. 2668-2673.

80. Tsao, A.S., et al., Increased phospho-AKT (Ser473) expression in bronchial dysplasia implications for lung cancer prevention studies. Cancer Epidemiology Biomarkers \& Prevention, 2003. 12(7): p. 660-664.

81. Kim, T.J., et al., Increased expression of pAKT is associated with radiation resistance in cervical cancer. British journal of cancer, 2006. 94(11): p. 16781682.

82. Wu, J., C. Chen, and K.-N. Zhao, Phosphatidylinositol 3-kinase signaling as a therapeutic target for cervical cancer. Current cancer drug targets, 2013. 13(2): p. 143-156.

83. Shingleton, H.M., et al., The current status of the Papanicolaou smear. CA: a cancer journal for clinicians, 1995. 45(5): p. 305-320.

84. Ronco, G. and N. Segnan, HPV testing for primary cervical cancer screening. The Lancet, 2007. 370(9601): p. 1740-1742.

85. Feltkamp, M.C., et al., Vaccination with cytotoxic T lymphocyte epitopecontaining peptide protects against a tumor induced by human papillomavirus type 16-transformed cells. European journal of immunology, 1993. 23(9): p. 2242-2249.

86. Chatterjee, A., The next generation of HPV vaccines: nonavalent vaccine V503 on the horizon. Expert review of vaccines, 2014. 13(11): p. 1279-1290.

87. Ferris, D., et al., Long-term study of a quadrivalent human papillomavirus vaccine. Pediatrics, 2014: p. peds. 2013-4144. 
88. Naud, P.S., et al., Sustained efficacy, immunogenicity, and safety of the HPV16/18 AS04-adjuvanted vaccine: final analysis of a long-term follow-up study up to 9.4 years post-vaccination. Human vaccines \& immunotherapeutics, 2014. 10(8): p. 2147-2162.

89. Creasman, W.T., Stage IA cancer of the cervix: finally some resolution of definition and treatment? Gynecologic oncology, 1999. 74(2): p. 163-164.

90. Creasman, W.T., et al., Early invasive carcinoma of the cervix (3 to $5 \mathrm{~mm}$ invasion): risk factors and prognosis: a Gynecologic Oncology Group study. American journal of obstetrics and gynecology, 1998. 178(1): p. 62-65.

91. Carter, J.S. and L.S. Downs Jr, cervical cancer Tests and Treatment. The female patient, 2011.36(1): p. 34.

92. Petrosky, E., et al., Use of 9-valent human papillomavirus (HPV) vaccine: updated HPV vaccination recommendations of the advisory committee on immunization practices. MMWR Morb Mortal Wkly Rep, 2015. 64(11): p. 300304.

93. Ansink, A., et al., Recurrent stage IB cervical carcinoma: evaluation of the effectiveness of routine follow up surveillance. BJOG: An International Journal of Obstetrics \& Gynaecology, 1996. 103(11): p. 1156-1158.

94. Duyn, A., et al., Recurrent cervical cancer: detection and prognosis. Acta obstetricia et gynecologica Scandinavica, 2002. 81(8): p. 759-763.

95. Morice, P., et al., Value of routine follow-up procedures for patients with stage I/II cervical cancer treated with combined surgery-radiation therapy. Annals of oncology, 2004. 15(2): p. 218-223.

96. DiMasi, J.A., R.W. Hansen, and H.G. Grabowski, The price of innovation: new estimates of drug development costs. Journal of health economics, 2003. 22(2): p. 151-185.

97. Paul, S.M., et al., How to improve R\&D productivity: the pharmaceutical industry's grand challenge. Nature reviews Drug discovery, 2010. 9(3): p. 203214.

98. Cohen, F.J., Macro trends in pharmaceutical innovation. Nature Reviews Drug Discovery, 2005. 4(1): p. 78-84.

99. Elliott, R.L., Four lessons from global health drug discovery: medicine for an ailing industry? ACS medicinal chemistry letters, 2012. 3(9): p. 688-690. 
100. Boguski, M.S., K.D. Mandl, and V.P. Sukhatme, Repurposing with a Difference. Science, 2009. 324(5933): p. 1394-1395.

101. Aubé, J., Drug repurposing and the medicinal chemist. ACS medicinal chemistry letters, 2012. 3(6): p. 442-444.

102. Alimova, I.N., et al., Metformin inhibits breast cancer cell growth, colony formation and induces cell cycle arrest in vitro. Cell cycle, 2009. 8(6): p. 909915.

103. Fendt, S.-M., et al., Metformin decreases glucose oxidation and increases the dependency of prostate cancer cells on reductive glutamine metabolism. Cancer research, 2013. 73(14): p. 4429-4438.

104. Zhang, Z.-J., et al., Reduced Risk of Colorectal Cancer With Metformin Therapy in Patients With Type 2 Diabetes A meta-analysis. Diabetes care, 2011. 34(10): p. 2323-2328.

105. Evans, J.M., et al., Metformin and reduced risk of cancer in diabetic patients. Bmj, 2005. 330(7503): p. 1304-1305.

106. Gasic, G., T. Gasic, and S. Murphy, Anti-metastatic effect of aspirin. The Lancet, 1972. 300(7783): p. 932-933.

107. Rothwell, P.M., et al., Effect of daily aspirin on long-term risk of death due to cancer: analysis of individual patient data from randomised trials. The Lancet, 2011. 377(9759): p. 31-41.

108. Din, F.V., et al., Effect of aspirin and NSAIDs on risk and survival from colorectal cancer. Gut, 2010. 59(12): p. 1670-1679.

109. Alvarado, Y., et al., Clinical activity of mammalian target of rapamycin inhibitors in solid tumors. Targeted oncology, 2011. 6(2): p. 69-94.

110. Récher, C., et al., Antileukemic activity of rapamycin in acute myeloid leukemia. Blood, 2005. 105(6): p. 2527-2534.

111. Sillaber, C., et al., Evaluation of antileukaemic effects of rapamycin in patients with imatinib-resistant chronic myeloid leukaemia. European journal of clinical investigation, 2008. 38(1): p. 43-52.

112. Kumar, R., et al., Selective estrogen receptor modulators regulate stromal proliferation in human benign prostatic hyperplasia by multiple beneficial mechanisms - action of two new agents. Investigational new drugs, 2012. 30(2): p. 582-593. 
113. Misra, N., et al., Centchroman-a non-steroidal anti-cancer agent for advanced breast cancer: Phase-II study. International Journal of Cancer, 1989. 43(5): p. 781-783.

114. Singh, M., Centchroman, a selective estrogen receptor modulator, as a contraceptive and for the management of hormone-related clinical disorders. Medicinal research reviews, 2001. 21(4): p. 302-347.

115. Lal, J., Clinical pharmacokinetics and interaction of centchroman-a mini review. Contraception, 2010. 81(4): p. 275-280.

116. Roy, S., et al., Induction of ovulation in the human with centchroman: a preliminary report. Fertility and sterility, 1976. 27(9): p. 1108-1110.

117. Seth, R., P. Kole, and J. Sarin, Studies on Centchroman a new antifertility compound. Indian journal of pharmaceutical sciences, 1983. 45(1): p. 14-6.

118. Roy, S. and J. Datta, Nature of estrogenic and anti-estrogenic actions of centchroman on rat uterus. Contraception, 1976. 13(5): p. 597-604.

119. Datta, J. and S. Roy, Effect of centchroman on morphological \& biochemical changes induced by testosterone propionate in uterus of rats. 1979.

120. Nair, R., T. Sheyte, and S. Munshi, Progestational \& antiprogestational effects of Centchroman in mouse \& rabbit. Indian journal of experimental biology, 1977. 15(12): p. 1157-1158.

121. Chandra, H., et al., Clinical pharmacology studies with Centchroman. Indian journal of experimental biology, 1977. 15(12): p. 1170.

122. Khurana, M., et al., Evaluation of interaction potential of certain concurrently administered drugs with pharmacological and pharmacokinetic profile of centchroman in rats. Contraception, 2002. 66(1): p. 47-56.

123. Srivastava, A., A. Agnihotri, and V. Kamboj, Binding of centchroman-a nonsteroidal antifertility agent to human plasma proteins. Experientia, 1984. 40(5): p. 465-466.

124. Paliwal, J. and R. Gupta, Tissue distribution and pharmacokinetics of centchroman. A new nonsteroidal postcoital contraceptive agent and its 7desmethyl metabolite in female rats after a single oral dose. Drug metabolism and disposition, 1996. 24(2): p. 148-155.

125. Ratna, S., et al., Centchroman: tissue distribution and excretion profile in albino rats after oral and intravenous administration. J Basic Appl Med, 1994. 2: p. 316. 
126. Lal, J., et al., Pharmacokinetics of centchroman in healthy female subjects after oral administration. Contraception, 1995. 52(5): p. 297-300.

127. Kumar Gara, R., et al., Anti-cancer potential of a novel SERM ormeloxifene. Current medicinal chemistry, 2013. 20(33): p. 4177-4184.

128. Srivastava, V.K., et al., Centchroman inhibits proliferation of head and neck cancer cells through the modulation of PI3K/mTOR pathway. Biochemical and biophysical research communications, 2011. 404(1): p. 40-45.

129. Yee, C., et al., Presence and expression of human papillomavirus sequences in human cervical carcinoma cell lines. The American journal of pathology, 1985. 119(3): p. 361.

130. Spanos, W.C., M. El-Deiry, and J.H. Lee, Cidofovir incorporation into human keratinocytes with episomal HPV 16 results in nonselective cytotoxicity. Annals of Otology, Rhinology \& Laryngology, 2005. 114(11): p. 840-846.

131. Singh, N., et al., Polyphenols sensitization potentiates susceptibility of MCF-7 and MDA MB-231 cells to Centchroman. PloS one, 2012. 7(6): p. e37736.

132. Mishra, R., et al., Therapeutic effect of centchroman alone and in combination with glycine soya on 7, 12-dimethylbenz [a] anthracene-induced breast tumor in rat. Food and Chemical Toxicology, 2010. 48(6): p. 1587-1591.

133. Pal, P., et al., 2-D gel electrophoresis-based proteomic analysis reveals that ormeloxifen induces G0-G1 growth arrest and ERK-mediated apoptosis in chronic myeloid leukemia cells K562. Proteomics, 2011. 11(8): p. 1517-1529.

134. Khan, S., et al., Ormeloxifene suppresses desmoplasia and enhances sensitivity of gemcitabine in pancreatic cancer. Cancer research, 2015. 75(11): p. 2292-2304.

135. Maher, D.M., et al., Ormeloxifene efficiently inhibits ovarian cancer growth. Cancer letters, 2015. 356(2): p. 606-612.

136. Brannon-Peppas, L. and J.O. Blanchette, Nanoparticle and targeted systems for cancer therapy. Advanced drug delivery reviews, 2004. 56(11): p. 1649-1659.

137. Gmeiner, W.H. and S. Ghosh, Nanotechnology for cancer treatment. Nanotechnology reviews, 2014. 3(2): p. 111-122.

138. Farokhzad, O.C. and R. Langer, Impact of nanotechnology on drug delivery. ACS nano, 2009. 3(1): p. 16-20.

139. Ferrari, M., Cancer nanotechnology: opportunities and challenges. Nature Reviews Cancer, 2005. 5(3): p. 161-171. 
140. Gaumet, M., et al., Nanoparticles for drug delivery: the need for precision in reporting particle size parameters. European journal of pharmaceutics and biopharmaceutics, 2008. 69(1): p. 1-9.

141. Conner, S.D. and S.L. Schmid, Regulated portals of entry into the cell. Nature, 2003. 422(6927): p. 37-44.

142. Rejman, J., et al., Size-dependent internalization of particles via the pathways of clathrin-and caveolae-mediated endocytosis. Biochemical Journal, 2004. 377(1): p. 159-169.

143. Hillaireau, H. and P. Couvreur, Nanocarriers' entry into the cell: relevance to drug delivery. Cellular and Molecular Life Sciences, 2009. 66(17): p. 2873-2896.

144. Owens, D.E. and N.A. Peppas, Opsonization, biodistribution, and pharmacokinetics of polymeric nanoparticles. International journal of pharmaceutics, 2006. 307(1): p. 93-102.

145. Alexis, F., et al., Factors affecting the clearance and biodistribution of polymeric nanoparticles. Molecular pharmaceutics, 2008. 5(4): p. 505-515.

146. Vinogradov, S.V., T.K. Bronich, and A.V. Kabanov, Nanosized cationic hydrogels for drug delivery: preparation, properties and interactions with cells. Advanced drug delivery reviews, 2002. 54(1): p. 135-147.

147. Choi, H.S., et al., Renal clearance of quantum dots. Nature biotechnology, 2007. 25(10): p. 1165-1170.

148. Ilium, L., et al., Blood clearance and organ deposition of intravenously administered colloidal particles. The effects of particle size, nature and shape. International journal of pharmaceutics, 1982. 12(2-3): p. 135-146.

149. Moghimi, S.M., et al., An investigation of the filtration capacity and the fate of large filtered sterically-stabilized microspheres in rat spleen. Biochimica et Biophysica Acta (BBA)-General Subjects, 1993. 1157(2): p. 233-240.

150. Porter, C.J., et al., The polyoxyethylene/polyoxypropylene block co-polymer Poloxamer -407 selectively redirects intravenously injected microspheres to sinusoidal endothelial cells of rabbit bone marrow. FEBS letters, 1992. 305(1): p. 62-66.

151. Peer, D., et al., Nanocarriers as an emerging platform for cancer therapy. Nature nanotechnology, 2007. 2(12): p. 751-760.

152. Manjunath, K. and V. Venkateswarlu, Pharmacokinetics, tissue distribution and bioavailability of clozapine solid lipid nanoparticles after intravenous and 
intraduodenal administration. Journal of Controlled Release, 2005. 107(2): p. 215-228.

153. Huang, Q., H. Yu, and Q. Ru, Bioavailability and delivery of nutraceuticals using nanotechnology. Journal of food science, 2010. 75(1): p. R50-R57.

154. Thrall, J.H., Nanotechnology and Medicine 1. Radiology, 2004. 230(2): p. 315318.

155. Panyam, J. and V. Labhasetwar, Biodegradable nanoparticles for drug and gene delivery to cells and tissue. Advanced drug delivery reviews, 2003. 55(3): p. 329347.

156. Cho, K., et al., Therapeutic nanoparticles for drug delivery in cancer. Clinical cancer research, 2008. 14(5): p. 1310-1316.

157. Torchilin, V., Tumor delivery of macromolecular drugs based on the EPR effect. Advanced drug delivery reviews, 2011. 63(3): p. 131-135.

158. Maeda, H., et al., Tumor vascular permeability and the EPR effect in macromolecular therapeutics: a review. Journal of controlled release, 2000. 65(1): p. 271-284.

159. Regehly, M., Photoinduced transfer processes in complex carrier systems for photodynamic therapy. 2008, Humboldt-Universität zu Berlin, MathematischNaturwissenschaftliche Fakultät I.

160. Matsumura, Y. and H. Maeda, A new concept for macromolecular therapeutics in cancer chemotherapy: mechanism of tumoritropic accumulation of proteins and the antitumor agent smancs. Cancer research, 1986. 46(12 Part 1): p. 6387-6392.

161. Muggia, F.M., Doxorubicin-polymer conjugates: further demonstration of the concept of enhanced permeability and retention. Clinical cancer research, 1999. 5(1): p. 7-8.

162. Vasey, P.A., et al., Phase I clinical and pharmacokinetic study of PK1 [N-(2hydroxypropyl) methacrylamide copolymer doxorubicin]: first member of a new class of chemotherapeutic agents-drug-polymer conjugates. Clinical Cancer Research, 1999. 5(1): p. 83-94.

163. Zhang, L., et al., Nanoparticles in medicine: therapeutic applications and developments. Clinical pharmacology and therapeutics, 2008. 83(5): p. 761-769.

164. Torchilin, V.P., Recent advances with liposomes as pharmaceutical carriers. Nature reviews Drug discovery, 2005. 4(2): p. 145-160. 
165. Berry, G., et al., The use of cardiac biopsy to demonstrate reduced cardiotoxicity in AIDS Kaposi's sarcoma patients treated with pegylated liposomal doxorubicin. Annals of Oncology, 1998. 9(7): p. 711-716.

166. Sharma, G., et al., Liposomes as targeted drug delivery systems in the treatment of breast cancer. Journal of drug targeting, 2006. 14(5): p. 301-310.

167. Duncan, R., Polymer conjugates as anticancer nanomedicines. Nature Reviews Cancer, 2006. 6(9): p. 688-701.

168. Davis, M.E. and D.M. Shin, Nanoparticle therapeutics: an emerging treatment modality for cancer. Nature reviews Drug discovery, 2008. 7(9): p. 771-782.

169. Dinarvand, R., et al., Polylactide-co-glycolide nanoparticles for controlled delivery of anticancer agents. Int J Nanomedicine, 2011. 6: p. 877-95.

170. Danhier, F., et al., PLGA-based nanoparticles: an overview of biomedical applications. J Control Release, 2012. 161(2): p. 505-22.

171. Makadia, H.K. and S.J. Siegel, Poly lactic-co-glycolic acid (PLGA) as biodegradable controlled drug delivery carrier. Polymers, 2011. 3(3): p. 13771397.

172. Kumari, A., S.K. Yadav, and S.C. Yadav, Biodegradable polymeric nanoparticles based drug delivery systems. Colloids and Surfaces B: Biointerfaces, 2010. 75(1): p. 1-18.

173. $\mathrm{Mu}, \mathrm{L}$. and S. Feng, A novel controlled release formulation for the anticancer drug paclitaxel (Taxol $\left.{ }^{\circledR}\right):$ PLGA nanoparticles containing vitamin E TPGS. Journal of controlled release, 2003. 86(1): p. 33-48.

174. Gref, R., et al., Biodegradable long-circulating polymeric nanospheres. Science, 1994. 263(5153): p. 1600-1603.

175. Park, J., et al., PEGylated PLGA nanoparticles for the improved delivery of doxorubicin. Nanomedicine: Nanotechnology, Biology and Medicine, 2009. 5(4): p. 410-418.

176. Yallapu, M.M., et al., Fabrication of curcumin encapsulated PLGA nanoparticles for improved therapeutic effects in metastatic cancer cells. J Colloid Interface Sci, 2010. 351(1): p. 19-29.

177. Yallapu, M.M., et al., Anti-cancer activity of curcumin loaded nanoparticles in prostate cancer. Biomaterials, 2014. 35(30): p. 8635-48. 
178. Yallapu, M.M., et al., Curcumin induces chemo/radio-sensitization in ovarian cancer cells and curcumin nanoparticles inhibit ovarian cancer cell growth. $\mathrm{J}$ Ovarian Res, 2010. 3: p. 11.

179. Acharya, S. and S.K. Sahoo, PLGA nanoparticles containing various anticancer agents and tumour delivery by EPR effect. Advanced drug delivery reviews, 2011. 63(3): p. 170-183.

180. Yoo, H.S., et al., In vitro and in vivo anti-tumor activities of nanoparticles based on doxorubicin-PLGA conjugates. Journal of Controlled Release, 2000. 68(3): $\mathrm{p}$. 419-431.

181. Yoo, H.S., et al., Biodegradable nanoparticles containing doxorubicin-PLGA conjugate for sustained release. Pharmaceutical research, 1999. 16(7): p. 11141118.

182. Chauhan, S.C., et al., MUC13 mucin augments pancreatic tumorigenesis. Molecular cancer therapeutics, 2012. 11(1): p. 24-33.

183. Petit, P.X., et al., Alterations in mitochondrial structure and function are early events of dexamethasone-induced thymocyte apoptosis. The Journal of cell biology, 1995. 130(1): p. 157-167.

184. Ly, J.D., D. Grubb, and A. Lawen, The mitochondrial membrane potential ( $\Delta \psi \mathrm{m})$ in apoptosis; an update. Apoptosis, 2003. 8(2): p. 115-128.

185. Scaduto, R.C. and L.W. Grotyohann, Measurement of mitochondrial membrane potential using fluorescent rhodamine derivatives. Biophysical journal, 1999. 76(1): p. 469-477.

186. Telford, W., L. King, and P. Fraker, Evaluation of glucocorticoid-induced DNA fragmentation in mouse thymocytes by flow cytometry. Cell proliferation, 1991. 24(5): p. 447-459.

187. Vermes, I., et al., A novel assay for apoptosis flow cytometric detection of phosphatidylserine expression on early apoptotic cells using fluorescein labelled annexin $V$. Journal of immunological methods, 1995. 184(1): p. 39-51.

188. Lecoeur, H., et al., Strategies for phenotyping apoptotic peripheral human lymphocytes comparing ISNT, annexin-V and 7-AAD cytofluorometric staining methods. Journal of immunological methods, 1997. 209(2): p. 111-123.

189. Kalyanaraman, B., et al., Measuring reactive oxygen and nitrogen species with fluorescent probes: challenges and limitations. Free Radical Biology and Medicine, 2012. 52(1): p. 1-6. 
190. Gottlieb, E., et al., Mitochondrial membrane potential regulates matrix configuration and cytochrome c release during apoptosis. Cell Death \& Differentiation, 2003. 10(6): p. 709-717.

191. Kumar, P. and J. Sreeramulu, A Stability-indicating Reversed-Phase High Performance Liquid Chromatography Method for Simultaneous determination of Ormeloxifene in Pure and Pharmaceutical Formulation. Int J ChemTech Res, 2011. 3(1): p. 314-320.

192. Khan, S., et al., Nanoparticle formulation of ormeloxifene for pancreatic cancer. Biomaterials, 2015. 53: p. 731-743.

193. Bertrand, N., et al., Cancer nanotechnology: the impact of passive and active targeting in the era of modern cancer biology. Adv Drug Deliv Rev, 2014. 66: p. $2-25$.

194. Acharya, S. and S.K. Sahoo, PLGA nanoparticles containing various anticancer agents and tumour delivery by EPR effect. Adv Drug Deliv Rev, 2011. 63(3): p. 170-83.

195. Peer, D., et al., Nanocarriers as an emerging platform for cancer therapy. Nat Nanotech, 2007. 2: p. 751-760.

196. Martins, K.F., et al., Preparation and characterization of paclitaxel-loaded PLDLA microspheres. Mater Res, 2014. 17(3): p. 650-656.

197. Mayor, S. and R.E. Pagano, Pathways of clathrin-independent endocytosis. Nature reviews Molecular cell biology, 2007. 8(8): p. 603-612.

198. Maher, D.M., et al., Ormeloxifene efficiently inhibits ovarian cancer growth. Cancer Lett, 2014.

199. Mishra, R., et al., Therapeutic effect of centchroman alone and in combination with glycine soya on 7,12-dimethylbenz [alpha] anthracene-induced breast tumor in rat. Food Chem Toxicol, 2010. 48(6): p. 1587-91.

200. Misra, N.C., et al., Centchroman--a non-steroidal anti-cancer agent for advanced breast cancer: phase-II study. Int J Cancer, 1989. 43(5): p. 781-3.

201. Nigam, M., et al., Centchroman induces G0/G1 arrest and caspase-dependent apoptosis involving mitochondrial membrane depolarization in MCF-7 and MDA MB-231 human breast cancer cells. Life Sci, 2008. 82(11-12): p. 577-90.

202. Nigam, M., et al., Centchroman mediated apoptosis involves cross-talk between extrinsic/intrinsic pathways and oxidative regulation. Life Sci, 2010. 87(23-26): p. $750-8$. 
203. Pal, P., et al., 2-D gel electrophoresis-based proteomic analysis reveals that ormeloxifen induces G0-G1 growth arrest and ERK-mediated apoptosis in chronic myeloid leukemia cells K562. Proteomics, 2011. 11(8): p. 1517-29.

204. Singh, M.M., Centchroman, a selective estrogen receptor modulator, as a contraceptive and for the management of hormone-related clinical disorders. Med Res Rev, 2001. 21(4): p. 302-47.

205. Srivastava, V.K., et al., Centchroman inhibits proliferation of head and neck cancer cells through the modulation of PI3K/mTOR pathway. Biochem Biophys Res Commun, 2011. 404(1): p. 40-5.

206. Paillard, A., et al., The importance of endo-lysosomal escape with lipid nanocapsules for drug subcellular bioavailability. Biomaterials, 2010. 31(29): p. 7542-54. 


\section{VITA}

Neeraj Chauhan was born in Rishikesh, Uttarakhand, India in the year of 1987. She obtained Bachelor of Science degree in July 2008. She came to the United States in August 2010 to pursue PhD program in Biomedical Sciences at the University of South Dakota (USD), Vermillion, SD, USA. In July 2013, she joined PhD program (as a transferred student) in Pharmaceutical Sciences with major in Pharmaceutics/Drug delivery at the University of Tennessee Health Science Center (UTHSC), Memphis, TN, USA. She has presented her research works in regional and national level conferences. She has authored and co-authored in several scientific articles. She has been an active member of AACR since 2012. She has served as the President for GSEC (Graduate Student Executive Council) from 2014-2015 and as the Program Representative (Pharmaceutical Sciences) from 2015-2016 at UTHSC. She received her doctorate degree with major in Pharmaceutics in May 2017. 